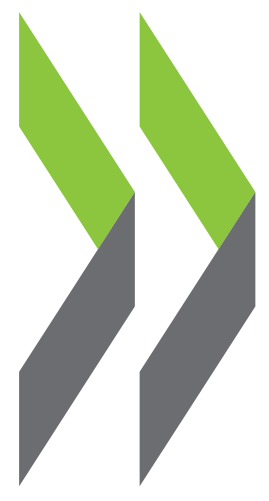

\title{
Economic Outlook for
} Southeast Asia, China and India 2020 - UPDATE

MEETING THE CHALLENGES OF COVID-19

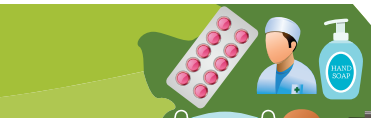

collo 20

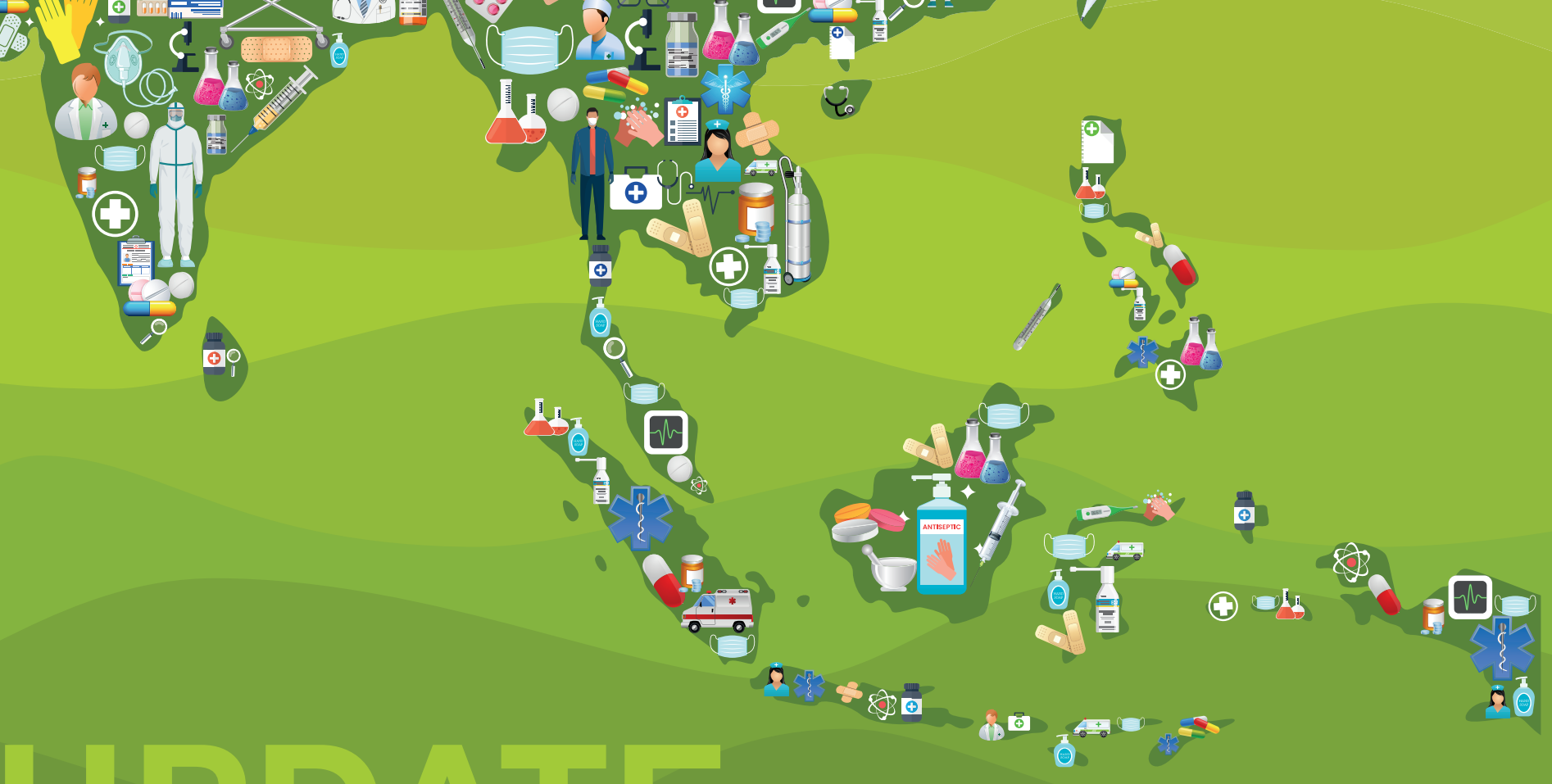




\section{Economic Outlook for Southeast Asia, China and India 2020 - Update}

MEETING THE CHALLENGES OF COVID-19

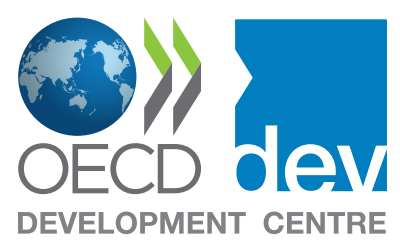


This work is published under the responsibility of the Secretary-General of the OECD. The opinions expressed and arguments employed herein do not necessarily reflect the official views of the member countries of the OECD or its Development Centre.

This document, as well as any data and map included herein, are without prejudice to the status of or sovereignty over any territory, to the delimitation of international frontiers and boundaries and to the name of any territory, city or area.

\section{Please cite this publication as:}

OECD (2020), Economic Outlook for Southeast Asia, China and India 2020 - Update: Meeting the Challenges of COVID-19, OECD Publishing, Paris, https://doi.org/10.1787/e8c90b68-en.

ISBN 978-92-64-64076-4 (print)

ISBN 978-92-64-36872-9 (pdf)

Economic Outlook for Southeast Asia, China and India ISSN 2310-1105 (print)

ISSN 2310-1113 (online)

Photo credits: Cover design by Aida Buendía (OECD Development Centre) on the basis of images from @ Shutterstock.com. 


\section{Foreword}

The Economic Outlook for Southeast Asia, China and India - Update is released following the main report of the Outlook, to ensure that its data, projections and policy discussions remain up-to-date and relevant. The Outlook is a biannual publication on Asia's regional economic growth, development and regional integration processes. It focuses on the economic conditions of the Association of Southeast Asian Nations (ASEAN) member countries (Brunei Darussalam, Cambodia, Indonesia, Lao People's Democratic Republic (hereafter "Lao PDR"), Malaysia, Myanmar, the Philippines, Singapore, Thailand and Viet Nam) and two large economies in the region, China and India.

Beginning with the first release of the Outlook Update in 2018, following the Special Supplements of the 2016 and 2017 editions, the Outlook has become a biannual publication. The first issue of the report will be released in the fall and its update released the following spring. This publication evolved from the Southeast Asian Economic Outlook.

The Outlook was initially proposed at an informal reflection group on Southeast Asia in 2008 as a follow-up of the Council Meeting at Ministerial level (MCM) in 2007 and was accepted by ministers/senior officials from ASEAN countries at the occasion of the 2nd OECD Southeast Asia Regional Forum in Bangkok in 2009. The Outlook project was officially launched in 2010 and each edition is regularly presented at the occasion of the ASEAN/East Asia Summit. It was included in the OECD's Southeast Asia Regional Programme (SEARP) at the Steering Group Meeting in Jakarta, Indonesia in March 2015, with its role of providing a horizontal view of activities, identifying emerging trends in the region and providing a backbone for the different streams of the Programme confirmed at the $2015 \mathrm{MCM}$. The Outlook serves as a strategic foresight and policy dialogue tool for the SEARP. The Outlook consultation group (OCG) was established in 2014 with OECD Delegations and Asian embassies in Paris.

This edition of the Update comprises three main parts, each highlighting a particular dimension of recent economic developments in the region. The first chapter presents the regional economic monitor, depicting the economic outlook and macroeconomic challenges in the region. The second chapter focuses on policy priorities in response to COVID-19 in Emerging Asia. The pandemic demonstrated the importance of digitalisation. Looking forward, policy makers need to maximise the use of digital tools while at the same time ensuring cyber security. Emergency support measures in the tourism sector need to be supplemented with a more holistic longer-term strategy. Policies in the health sector are needed not only to curb the spread of the virus, but also to prepare healthcare systems for potential future outbreaks. Regional initiatives to deal with the pandemic and its effects are currently underway and need to be strengthened going forward. The topic of boosting education quality in the region is discussed in the third chapter, providing some policy recommendations drawing from PISA 2018, including: improved access to and better quality education, making learning time more productive, addressing gender differences as well as socio-economic divides among schools, creating a positive learning environment, and investing greater resources in the school system.

The OECD Development Centre is committed to working alongside governments of developing and emerging economies and regional actors to identify key areas of intervention in order to address these challenges. The Centre enjoys the full membership of three Southeast Asian countries, namely Indonesia, Thailand and Viet Nam, as well as India and China. This project has also benefitted from the generous support of other Emerging Asian countries.

The OECD is committed to supporting Asian countries in their efforts to promote economic and social well-being through rigorous analysis, peer learning and the sharing of best practices. 



\section{Acknowledgements}

The Economic Outlook for Southeast Asia, China and India 2020 - Update: Meeting the challenges of COVID-19 was prepared by the Asia Desk of the OECD Development Centre, in co-operation with the Directorate for Education of the OECD. The publication benefitted from discussions with regional partners, including the ASEAN Secretariat, ASEAN+3 Macroeconomic Research Office (AMRO), the Asian Development Bank (ADB), the Asian Development Bank Institute (ADBI), and the Economic Research Institute for ASEAN and East Asia (ERIA). The team was led by Kensuke Tanaka, Head of the Asia Desk and valuable guidance was provided by Mario Pezzini, Director of the OECD Development Centre and Special Advisor to the Secretary-General on Development.

This volume was drafted by a core team composed of Kensuke Tanaka, Prasiwi Ibrahim, Raluca Maran, Ryan Jacildo, Alexander Hume, Zezhong Li, Miyako Ikeda and Alfonso Echazarra. Lea Ortega provided useful inputs and Sonja Marki valuable administrative support for this project. Delphine Grandrieux, Elizabeth Nash, Aida Buendia, Marika Boiron and Studio Pykha turned the manuscript into the publication.

The Outlook 2020 Update benefitted from discussions with OECD Delegations at three Outlook Consultation Group (OCG) Meetings in February 2019, September 2019 and February 2020 in Paris, led by co-chairs of this consultation group, Ambassador Nguyen Thiep and Christoph Graf, together with Ambassador Manuel Escudero. The Outlook also benefitted from discussion with experts in the region at the $8^{\text {th }}$ Asian Regional Roundtable on Macroeconomic and Structural Policies, jointly organised by AMRO, ADB, ADBI, ERIA and the OECD Development Centre, in Tokyo on 13-14 February 2020. The authors are grateful to Naoyuki Yoshino, Dean of the ADBI, Toshinori Doi, Director of AMRO, Hidetoshi Nishimura, President of ERIA, as well as Chul Ju Kim, Nella Hendriyetty, Yumiko Murakami, Koji Hachiyama, Anita Prakash, Abdul Abiad, Reza Anglingkusumo, Ho Sui Jade, Patrick Hess, Aladdin Rillo, Samantha Hung, and Donny Hutabarat. The full Outlook 2020 report was also presented at the occasion of the ASEAN/East Asia Summit in Bangkok, Thailand in November 2019.

Support from OECD delegations and embassies of Asian countries in Paris in particular Ambassador Hyoung Kwon Ko, Chargée d'affaires Seong-ho Lee, Ambassador Hiroshi Oe, Ambassador Sarun Charoensuwan, Ambassador Dato' Azfar Mohamad Mustafar, Ambassador Kyaw Zeya, Ambassador Zainal Mantaha, Thi Van Anh Nguyen, Nguyen Tan Van, Thanh Thao Nguyen, Hye Won Kim, Yoonrae Park, Taro Fujii, Satoshi Watarai, Akane Nozawa, Satoshi Nishijima, Sasilada Kusump, Sherwin Loh, Philip Pierros, Rudjimin, Lydia Safitri, Karina Ratnamurti, Hans Siriban, Hazel Imperial, Premanand Jothy, Syed Nizamuddin Sayed Khassim, Houmphanh Soukprasith, Zaidah Shahminan, Mang Hau Thang, Phe Grace Mee, Liwnapha Chanthavone, Sisavanh Phimsavanh, Litthiphone Silileuxay, Sakthavy Xaobouddavong, Chanphanith Chhay, Sokan Oum, Sonisa Eat, Morakot Vongxay and Chhavy Sovann is gratefully acknowledged; as are contributions from the European Commission.

Last but not least, the OECD Development Centre would like to express deep appreciation for the financial support received from the governments of Japan, Korea and Switzerland, and the European Union. 



\section{Table of contents}

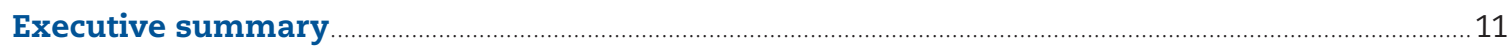

Overview .

Chapter 1. Macroeconomic assessment and economic outlook ................................................................. 35

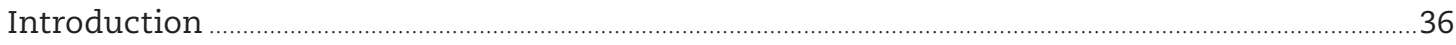

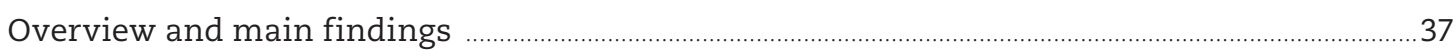

Recent developments and near-term outlook ........................................................................................ 41

Governments have fiscal leeway but limited space calls for efficient spending …….....................70

The sizeable cost of COVID-19 will test fiscal management .................................................................72

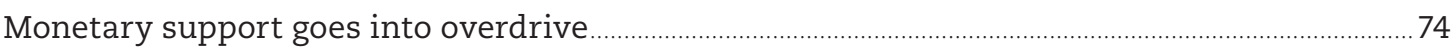

Risk remains elevated in financial markets …….................................................................................. 75

Banking sector braces for profit and solvency risks.................................................................................... 80

Capital flow and exchange-rate volatility risks are brewing ...................................................

Inflation in the region has moderated, but oil prices could surge anew ….................................83

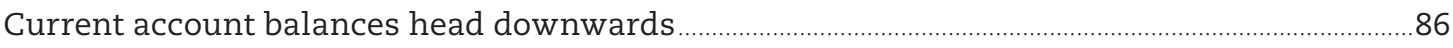

Conclusion .

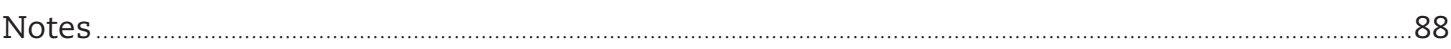

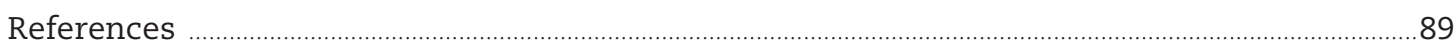

Annex 1.1. Detailed summary of key macro-policy responses to COVID-19 ….........................92

Chapter 2. Policy priorities in response to COVID-19 in Emerging Asia ................................................97

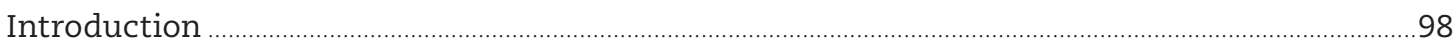

Surging demand for digital tools creates an opportunity for Emerging Asia ……………................98

Travel and tourism suffer a major blow in global health crisis ....................................................... 107

Countries scramble to update health policies to address the pandemic …....................................111

Emerging Asia strengthens collaboration to fight the pandemic ......................................................... 118

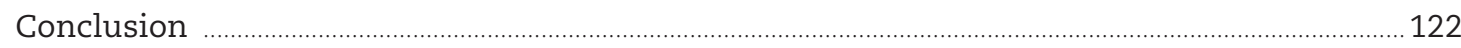

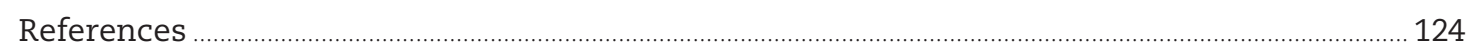

Chapter 3. Boosting education quality in Emerging Asia: Recommendations from PISA 2018 …..... 127

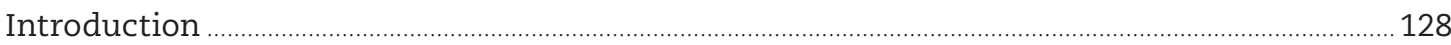

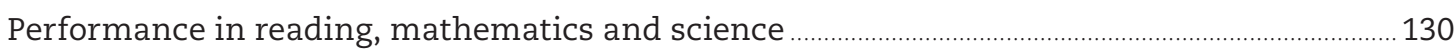

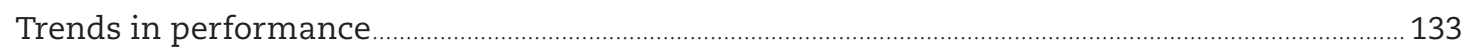

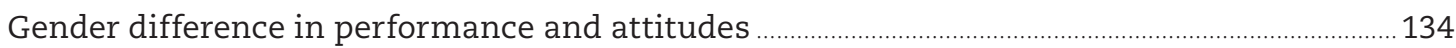

The socio-economic divide: Performance, attitudes and school resources .................................. 138

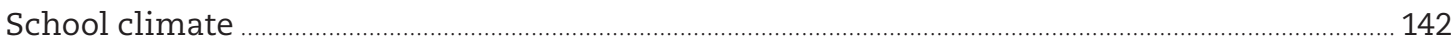

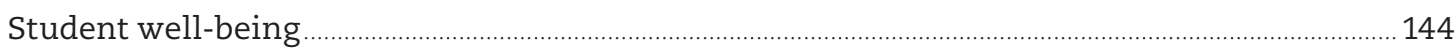

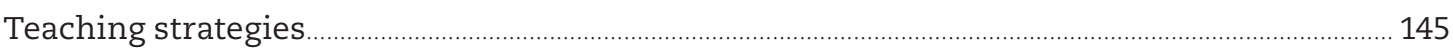

Some policy recommendations for the education systems in the region ....................................... 148

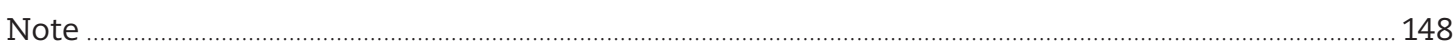

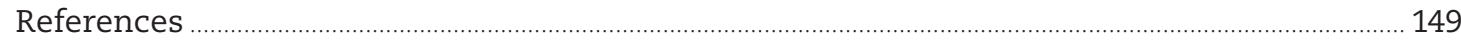

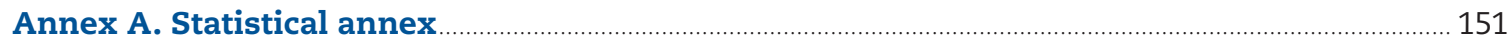


Figures

1. Manufacturing and services in selected ASEAN economies, 2016-20 ..................................13

2. Most affected areas in ASEAN-5, share in COVID-19 cases and national GDP ........................ 14

3. Unemployment, underemployment and labour informality in Emerging Asia .....................15

4. Personal remittances and stock of nationals abroad, Emerging Asia ....................................... 16

5. Monetary policy actions in selected Emerging Asian economies, 2020 ..................................19

6. Total amount of fiscal packages and estimated impact on the fiscal balance of selected Emerging Asian economies...............................................................................................

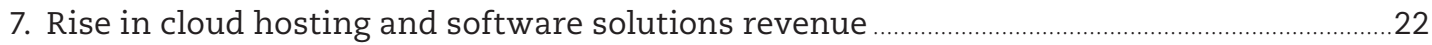

8. Visitor arrivals plummeted as restrictions on international travel tightened ......................2 24

9. Hospital beds and COVID-19 mortality in selected Emerging Asian economies ....................26

10. Performance in reading, mathematics and science ......................................................................30

11. Difference in shortage of educational material and staff,

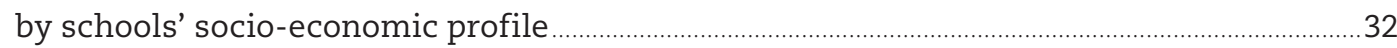

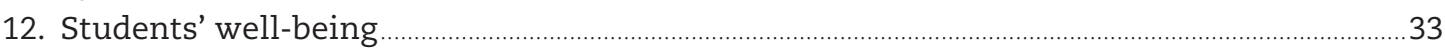

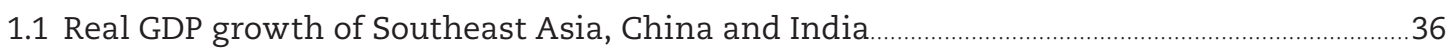

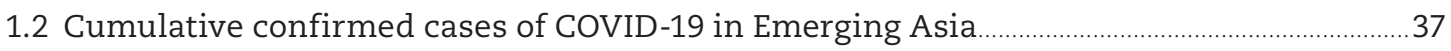

1.3 Contribution to growth by components in ASEAN-5, 2018-20 …...........................................44

1.4 COVID-19 confirmed cases and case fatality rates in Emerging Asia ......................................46

1.5 Most affected areas in ASEAN-5, share in COVID-19 cases and national GDP........................47

1.6 Unemployment, underemployment and labour informality in Emerging Asia .....................49

1.7 Personal remittances and stock of nationals abroad, Emerging Asia .......................................50

1.8 Consumer confidence indices and retail sales growth in ASEAN-5, 2019-20 .........................51

1.9 Change in share of services and manufacturing in manufacturing total intermediate inputs in Emerging Asia between 2010 and 2017 .....................................52

1.10 Manufacturing and services in selected ASEAN economies, 2016-20 .......................................53

1.11 Contributions to GDP growth by components in Brunei Darussalam

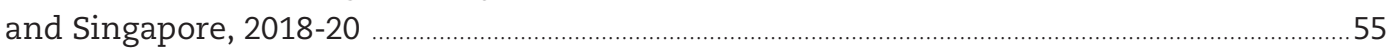

1.12 Private consumption and gross exports, real year-on-year growth .........................................57

1.13 Tourist arrivals and goods exports growth in Southeast Asia, 2019-20 ..................................58

1.14 Contributions to GDP growth by components in Cambodia, Lao PDR

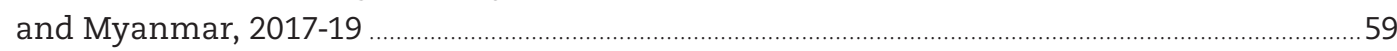

1.15 Contributions to GDP growth by components in China and India, 2017-20 ...........................61

1.16 PM 2.5 concentration in China, February 2019 vs. February 2020 ........................................62

1.17 China's share in inputs to the manufacturing exports of other

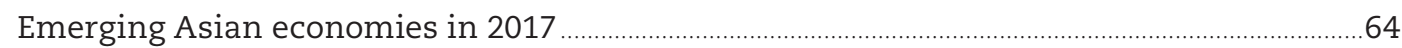

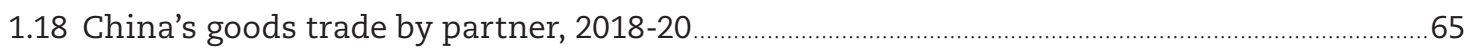

1.19 US goods imports by partner, 2018-20 ...................................................................................................66

1.20 Confidence indices, goods exports and tourist arrivals, India, 2018-20 ...............................68

1.21 Total amount of fiscal packages and estimated impact on the fiscal balance of selected Emerging Asian economies...................................................................................................70

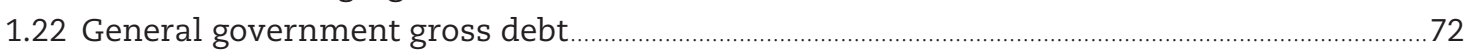

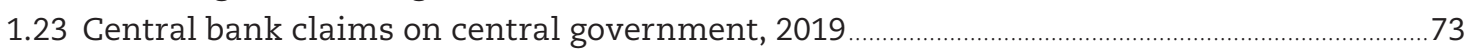

1.24 Monetary policy actions in selected Emerging Asian economies, 2020 .................................75

1.25 Changes in stock price indices and bond yield and term spreads in Emerging Asia, 2019-20 
1.26 Price-to-earnings (P/E) ratio for selected Emerging Asian stock markets and sectors, 2018-20

1.27 Bond yield index and spreads in selected Emerging Asian economies, January-July 2020 _......78

1.28 Yield curve in selected Emerging Asian economies, January-July 2020 ......................................78

1.29 Credit default swap spreads in selected Emerging Asian economies, 2016-20.........................79

1.30 Developments in corporate bond defaults in China, 2018-20 …........................................... 79

1.31 Capital adequacy ratio (CAR) Tier-1, return on equity (ROE)

and non-performing loan (NPL) ratio levels and change in Emerging Asia, 2018-19 ….........80

1.32 Foreign direct investment in Emerging Asian countries, 2019-20 ……............................

1.33 Changes in nominal effective and US dollar exchange rates in Emerging Asia, 2019-20 .........82

1.34 Headline, core and food inflation in Emerging Asia, 2018-20 ...................................................84

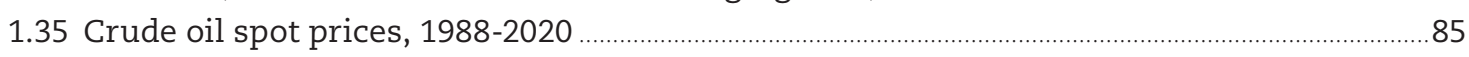

1.36 Current account balances in ASEAN, China and India, 2019-21 ………................................ 87

2.1 Zoom downloads, Q4 2019 to Q1 2020

2.2 Rise in cloud hosting and software solutions revenue

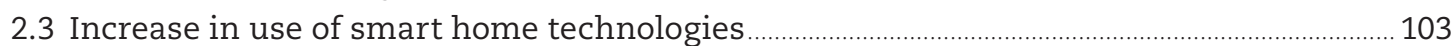

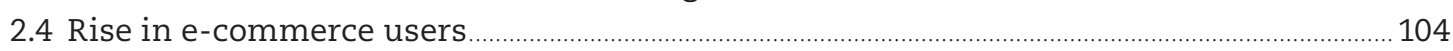

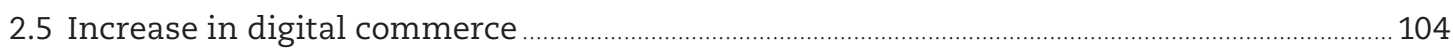

2.6 Rise in use of fresh food e-commerce apps in China................................................................. 105

2.7 Visitor arrivals in selected Emerging Asian countries, 2018-20 .......................................... 108

2.8 Visitor arrivals plummeted as restrictions on international travel tightened ..................... 108

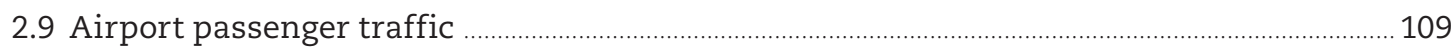

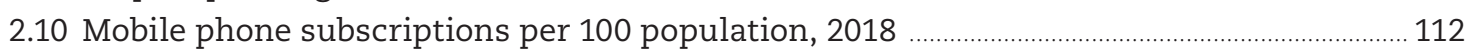

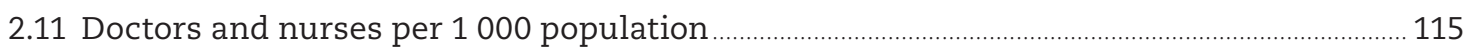

2.12 Hospital beds and COVID-19-related mortality in selected Emerging Asian economies ........ 115

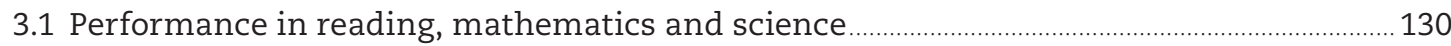

3.2 Proficiency levels in reading, mathematics and science ...................................................... 132

3.3 Gender gaps in reading and mathematics performance …................................................ 135

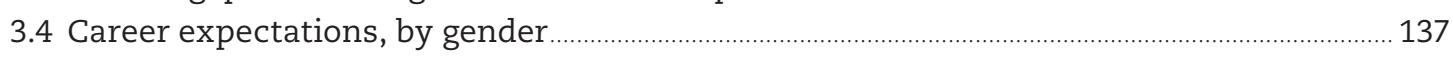

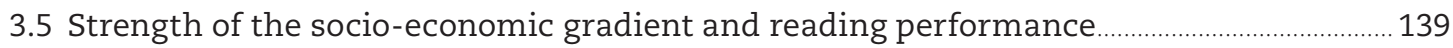

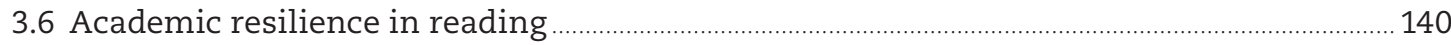

3.7 Difference in shortage of educational material and staff,

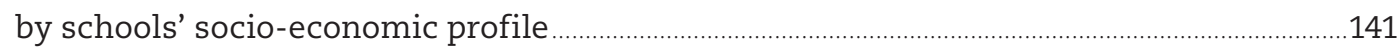

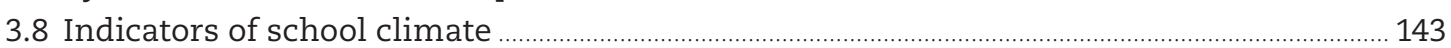

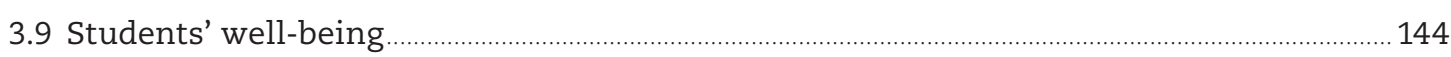

3.10 Teaching practices in language-of-instruction lessons .................................................................... 146

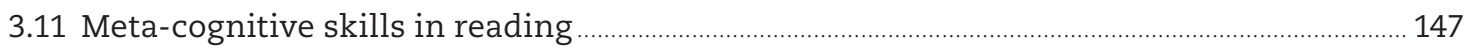

Tables

1. Real GDP growth in ASEAN, China and India, 2019-21 ….............................................................

2. Examples of region-wide pandemic initiatives in ASEAN and ASEAN Plus Three ................27

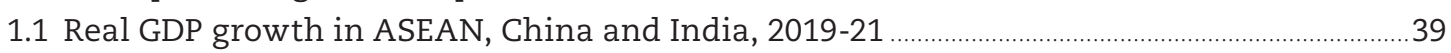

1.2 Comparative global toll of epidemics since the 1950s

1.3 Overview of COVID-19 lockdown measures in Emerging Asian countries .............................43

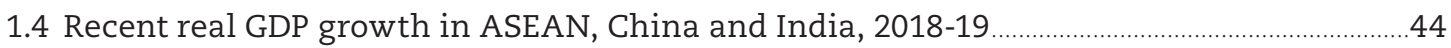

1.5 Length and estimated impact of lockdown measures in Emerging Asia ........................................69 
2.1 Use of online medical apps in China during the pandemic ........................................................... 101

2.2 Examples of additional medical expenditures due to COVID-19 .........................................114

2.3 COVID-19 research contributions and phases, by selected countries and organisations ....... 116

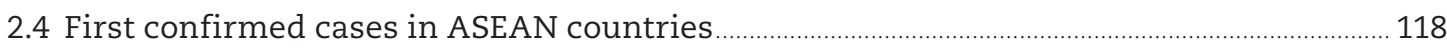

2.5 Examples of region-wide pandemic initiatives in ASEAN and ASEAN Plus Three .............. 118

3.1 Participation of Southeast Asian countries in PISA ……................................................................... 129

3.2 Features of the PISA 2018 participation of Southeast Asian countries …………….................130

3.3 Indices of teacher practices

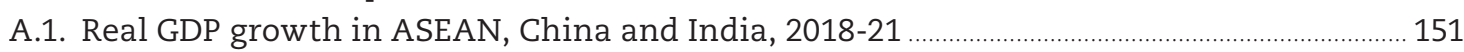

A.2. Current account balance of ASEAN, China and India, 2019-21 ........................................ 151

\section{Boxes}

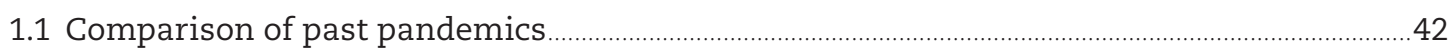

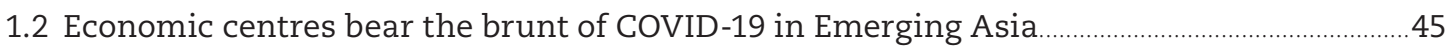

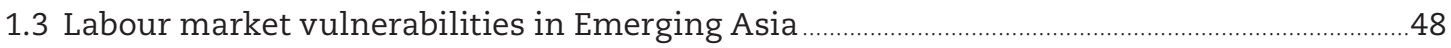

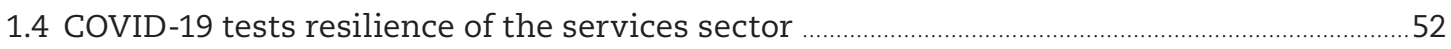

1.5 Rough waters for tourism and trade in Emerging Asia …………...............................................5

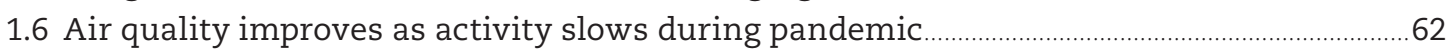

1.7 Implications of COVID-19 for global value chains in Emerging Asia ...........................................63

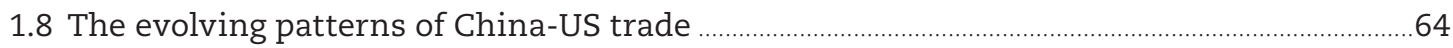

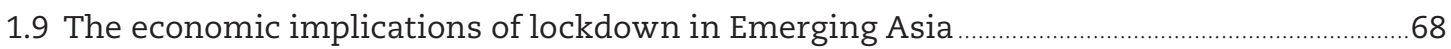

1.10 Volatility of corporate bond defaults in China ................................................................ 79

1.11 Oil prices add to the pressure on Emerging Asian economies …….....................................85

2.1 Tech businesses emerge as winners during the COVID-19 period ……...................................98

2.2 COVID-19 and the digital medical industry in China ................................................................... 101

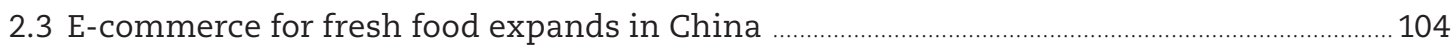

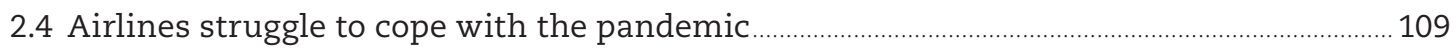

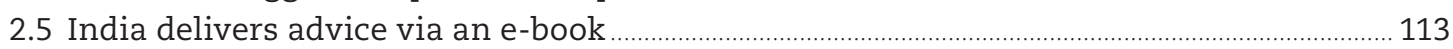

2.6 International pandemic support for and from ASEAN countries ........................................ 117

2.7 Health co-operation mechanisms in the framework of ASEAN and ASEAN Plus Three ........ 119

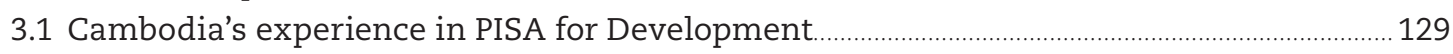

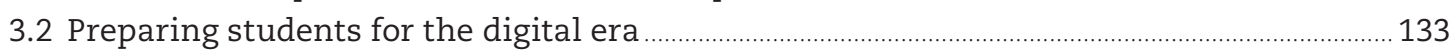

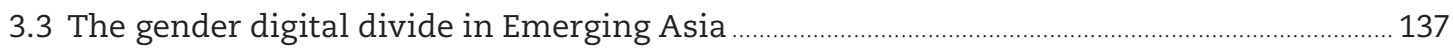

3.4 Socio-economic divide in students' ICT access …................................................................... 


\section{Executive summary}

As shockwaves from the COVID-19 pandemic disrupt economies around the world, growth rates in Emerging Asia are expected to contract in 2020 before rebounding in 2021. The OECD's Economic Outlook for Southeast Asia, China and India 2020 - Update describes the impact of the crisis on the economies of the region. In addition to the near-term regional economic outlook, it presents policy priorities for coping with the crisis, with a focus on digitalisation, tourism, healthcare and regional co-operation. It also examines the need to boost education quality in Emerging Asia.

\section{Economic outlook for 2020 and 2021}

Gross domestic product (GDP) in 2020 is expected to decline by $2.9 \%$ on average in Emerging Asia and by $2.8 \%$ in ASEAN-10. Growth rates are projected to return to levels similar to those seen previously in 2021 , by $6.8 \%$ in Emerging Asia and by $5.6 \%$ in ASEAN. With an estimated GDP decline of $6.7 \%$ in 2020, Thailand is expected to be the worst affected economy in Emerging Asia. Viet Nam will outperform its ASEAN-5 counterparts, posting a positive GDP growth for 2020 and the strongest growth in 2021. The CLM countries - Cambodia, Lao People's Democratic Republic (hereafter "Lao PDR") and Myanmar - have also been negatively impacted and Cambodia's GDP growth will turn negative in 2020. In China and India, economic output is expected to contract for the first time in decades before returning to a positive growth trajectory in 2021.

While financial markets in the region have proved resilient, the risk of capital flow volatility is broadening, as are risks to banking sector profitability and solvency. Countries where banks are worse positioned to support firms and households, such as India and to some extent Lao PDR, Myanmar and Viet Nam, are arguably more susceptible to shocks. The corporate sector is facing unprecedented pressure as a consequence of measures implemented to curb the spread of the virus. In all countries, unemployment levels and corporate bankruptcies are a major concern.

Governments in Emerging Asia have adopted fiscal stimulus policies of unprecedented proportions, and policy makers have ramped up monetary accommodation. The crisis and associated recovery programmes will push the fiscal limits of many economies into uncharted territory. Although most Emerging Asian countries entered the crisis with relatively sound fiscal positions, the sheer spending requirements to help the real economy regain its pre-pandemic health will put these fiscal buffers to the test. With Emerging Asia highly susceptible to natural disasters such as storms and flooding, particularly in the second half of the year, many governments in the region will be hard-pressed to manage the increase in their initially planned fiscal deficit ratios.

\section{Policy priorities in response to COVID-19}

The COVID-19 crisis will lead to lasting transformations and should benefit firms that enable online and technology-based services. The use of online services for virtual meetings and teaching increased sharply during the outbreak, with similar trends in e-commerce and e-banking. The crisis also illustrated the growth potential of online health sites and applications. While digital transformation is occurring rapidly in China, India, Indonesia and Singapore, other Southeast Asian economies are facing difficulties during the crisis, especially those with insufficient IT infrastructure and Internet availability. 
Travel and tourism were among the sectors worst impacted by COVID-19 in Emerging Asia. Travel restrictions were imposed in all countries in the region. Several ASEAN countries implemented fiscal packages to support workers in travel and tourism, while others have sought to stimulate domestic tourism to keep tourism-related businesses operating and workers employed. Co-ordination among tourism officials, health officials and local authorities at domestic tourist destinations is primordial in the trade-off between resuming activity and safeguarding public health. Appropriate strategies will also need to be crafted for the safe resumption of international travel flows.

The COVID-19 crisis has shown that ASEAN countries need to improve the state of their healthcare systems. Every ASEAN country has fewer hospital resources per capita than the OECD average, in terms of both personnel and physical infrastructure. At the same time, public awareness about best practices during a pandemic may be rather low across parts of Emerging Asia. Targeted policies could be envisaged on several fronts, including the development of tracing methods, the use of education to promote better hygiene and an increase in medical personnel and healthcare facilities. International co-operation is proving crucial in the effort to develop a vaccine, and countries in Emerging Asia are assisting each other through donations of supplies to control the spread of the virus.

Since the first COVID-19 cases were reported in January, ASEAN leaders and their counterparts in China, Japan and Korea have stepped up efforts to provide a collective response. These initiatives have included information sharing, co-ordination in responding to public health challenges, and economic measures such as keeping ASEAN markets open for trade and investment or strengthening supply-chain resilience and sustainability. The scope of region-wide initiatives could still be expanded. Going forward, countries will need to ensure that public health and financial responses to both the current emergency and future outbreaks are effectively co-ordinated.

\section{Boosting education quality}

The spread of COVID-19 has left learners across the globe out of school, even if temporarily. While learning has continued in one way or another, the consequences of the school closures have been particularly damaging for vulnerable students. Although the full consequences of the school closures cannot yet be evaluated, the results of the Programme for International Student Assessment (PISA) 2018 can provide a valuable reference point for education systems.

While acknowledging progress in some areas, the 2018 PISA exercise also revealed challenges in education systems in Emerging Asia. These shortcomings could be addressed through targeted policies aimed at improving access to education, allocating resources more equitably among schools, addressing gender imbalances in student participation and creating a positive learning environment. 


\section{Overview}

\section{Macroeconomic assessment and economic outlook}

The COVID-19 pandemic has caused economies around the world to falter to degrees not experienced in decades. Emerging Asian countries (ASEAN 10 countries, China and India) had confirmed more than 1.3 million cases as of early July, with a case fatality rate of roughly $3 \%$. Governments mustered massive monetary and fiscal support to lessen the immense stress on health services and keep the social fabric intact. Quarantines and curfews were imposed to limit the spread of the virus, although these in turn hampered economic activity. The progress in containing infections has been uneven across Emerging Asia. India, Indonesia and the Philippines are still confronting rising case loads.

Growth prospects of Emerging Asian economies, which were already weakening before the outbreak, have absorbed big blows on several fronts. Q1 2020 data convey feebleness across demand and supply components in all reporting countries in the region. Even the customarily resilient services sectors are wilting from the stress of COVID-19 despite buoyancy induced by deepening digitalisation (Figure 1). Understandably, the health emergency has weighed heavily on aggregate private spending and investment. The partial or total closure of factories and offices have resulted in production cutbacks.

Figure 1. Manufacturing and services in selected ASEAN economies, 2016-20 Year-on-year growth, percentage
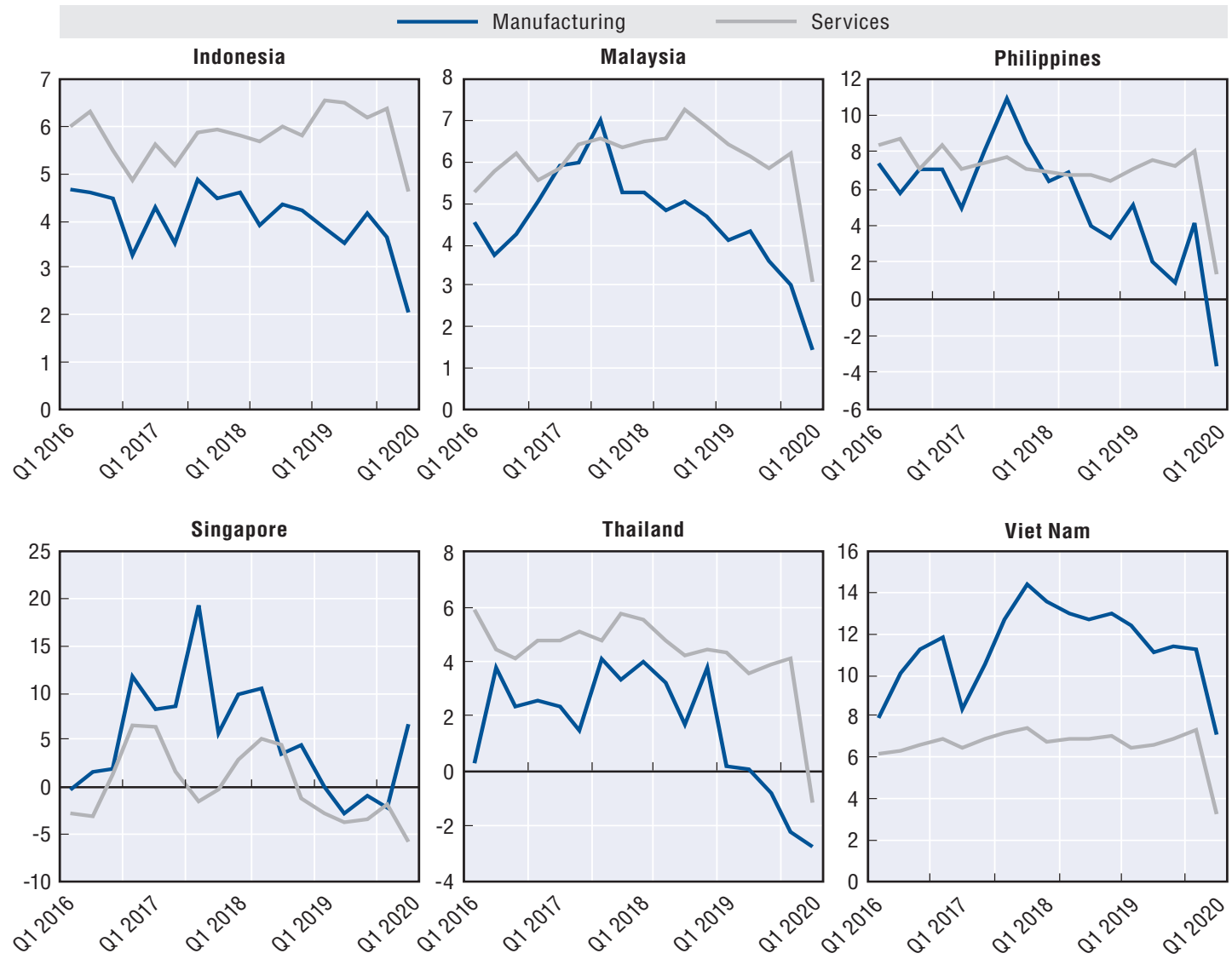

Note: Data for Viet Nam are year-to-date.

Source: OECD Development Centre based on CEIC.

StatLink 部赤 https://doi.org/10.1787/888934160513 
The fact that COVID-19 spread in the most densely populated and economically active areas has made it more difficult to deal with the health and ecomonic effects of the pandemic. Subnational-level data in ASEAN-5 show that cases of infection are disproportionately higher in major cities and urban areas. This is particularly glaring in the Philippines, where Metro Manila (the National Capital Region) and Central Visayas account for close to $70 \%$ of total officially confirmed cases. Bangkok accounts for about $50 \%$ of the confirmed cases in Thailand (Figure 2).

Figure 2. Most affected areas in ASEAN-5, share in COVID-19 cases and national GDP

Percentage

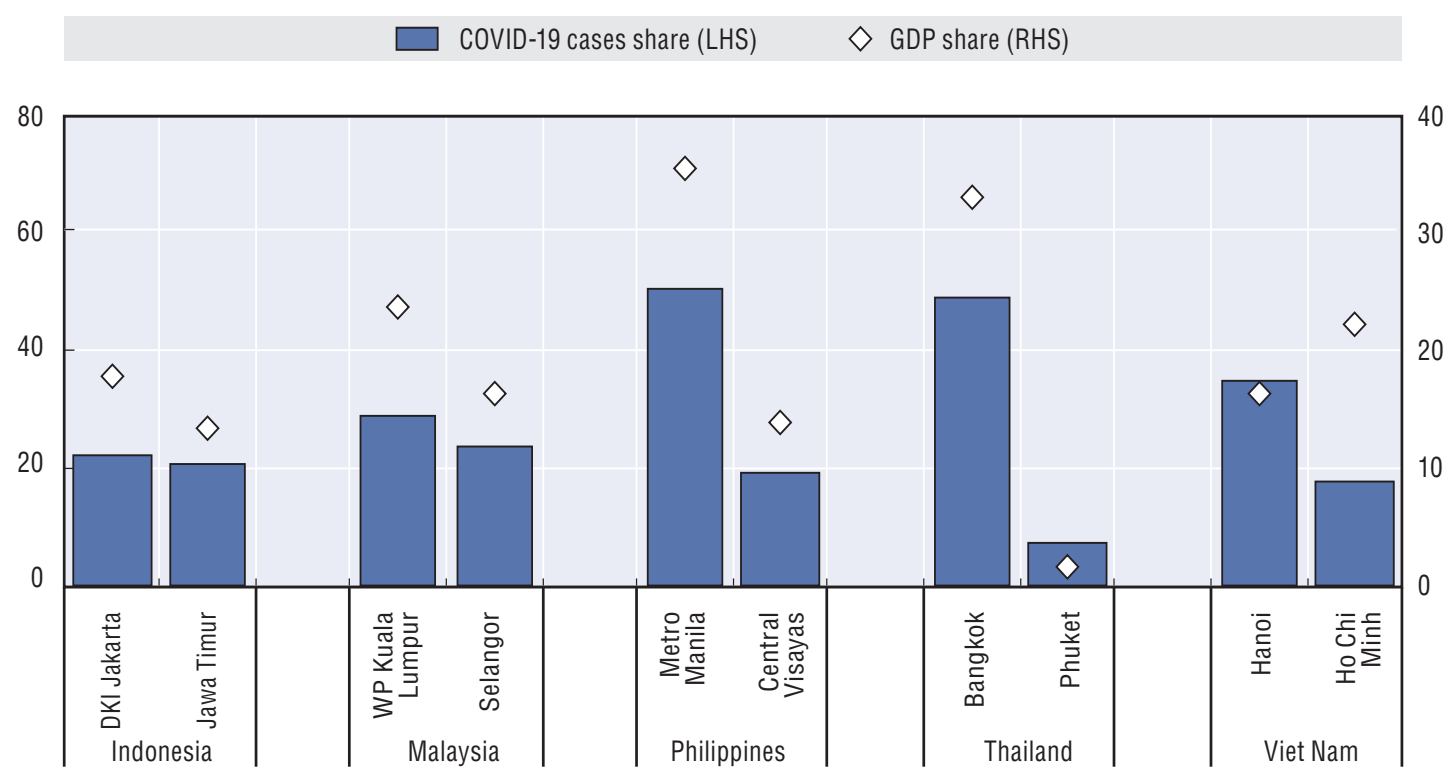

Note: Agglomerations are based on the definitions of national authorities as published. They may or may not be strictly comparable across countries. Only the top two areas in terms of share are included in the chart. COVID-19 data are as of 21 June 2020. GDP shares are based on current price series except for Malaysia (constant price) and refer to 2019 for Indonesia and 2018 for the rest. LHS means left-hand scale. RHS means right-hand scale.

Source: OECD Development Centre based on national sources and CEIC.

StatLink (inilst https://doi.org/10.1787/888934160608

Although quarantines and restrictions on movement have been relaxed in a number of countries to restart economic engines, the path to normalcy is beset by uncertainties, and economic recovery is expected to be very gradual. It will likely take a few quarters before the crisis-related restrictions imposed in many countries are lowered to nil. The expansion of private consumption will be measured, given the broad and deep impact of the pandemic on labour markets.

A portion of the jobs lost, especially in the hospitality industry, cannot be restored in a short period. In particular, recovery in the aviation sector is anticipated to be slow. Levels of underemployment and labour informality, as well as the lack of well-established unemployment protection, are additional labour market vulnerabilities in Emerging Asia. Underemployment rates in Brunei Darussalam, Lao People's Democratic Republic (hereafter "Lao PDR") and the Philippines exceeded an estimated 10\% of the labour force in 2019 (Figure 3), while labour informality in the non-agriculture sector comprises 
more than half of all workers in many countries in the region (Figure 3). "No work, no pay" situations in already low-paying jobs place many of these workers at the mercy of emergency government subsistence allowances.

\section{Figure 3. Unemployment, underemployment and labour informality} in Emerging Asia
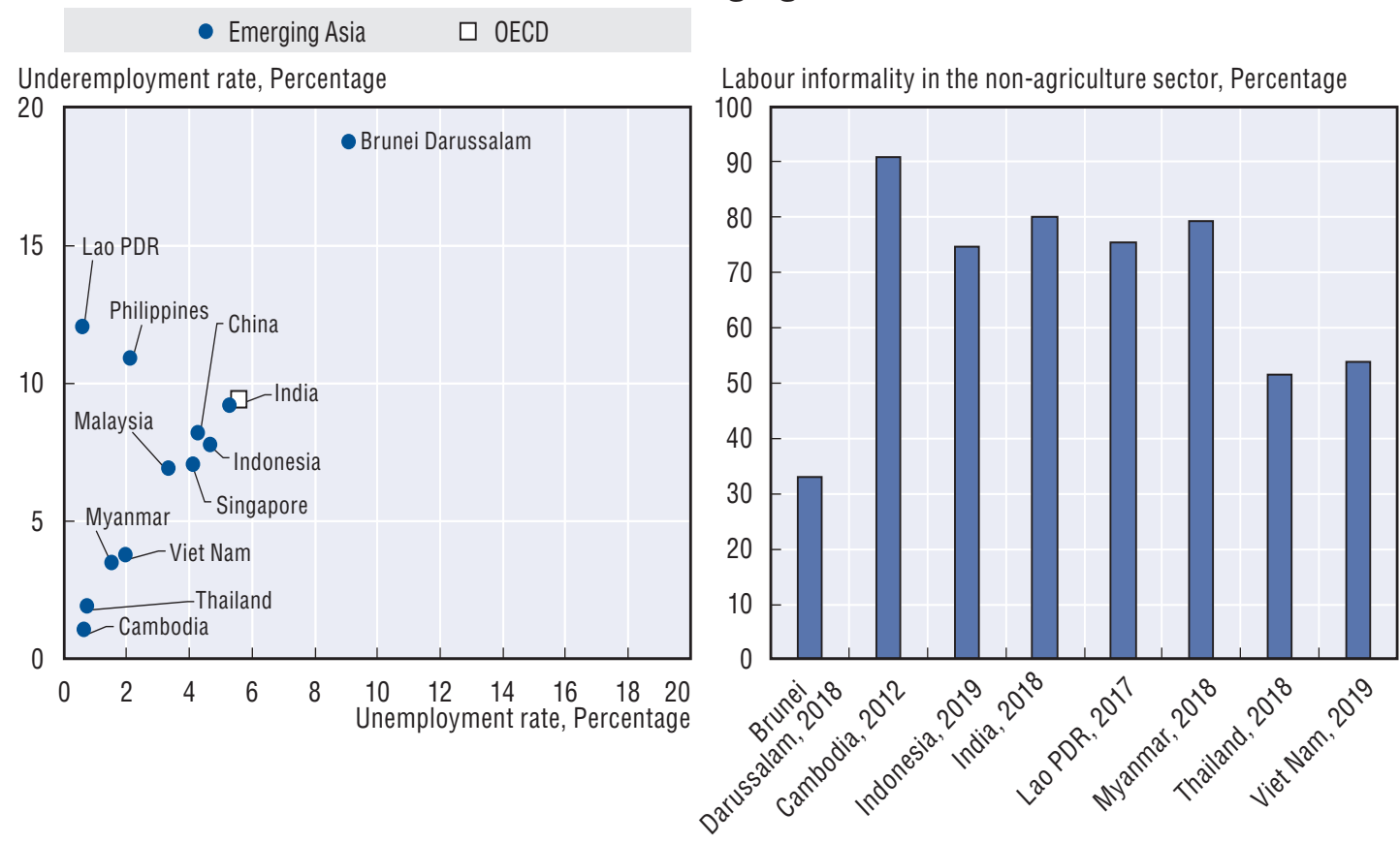

Note: The unemployment and time-related underemployment data refer to the International Labour Organization (ILO) modelled estimates in November 2019. The OECD data refer to the simple average of the 36 countries using ILO data. Labour informality refers to the proportion of informal employment in non-agricultural employment (harmonised series) of ILO.

Source: OECD Development Centre and ILO.

StatLink 部占 https://doi.org/10.1787/888934160627

The ongoing pandemic also creates employment instability for overseas workers. Land-based and sea-based foreign workers, such as the manpower for cargo and cruise ships, are affected to the same extent. Displacement of foreign workers means not only reduced remittances, and therefore lower purchasing power for dependent households, but also additional entrants to the domestic labour market. The Philippines received about 9.3\% of GDP in remittances in 2019 and has a high stock of nationals overseas (Figure 4). Considering the labour market challenges, spending on basics and the rebuilding of the precautionary savings pool are anticipated to take precedence among households during the recovery period. 
Figure 4. Personal remittances and stock of nationals abroad, Emerging Asia Percentage
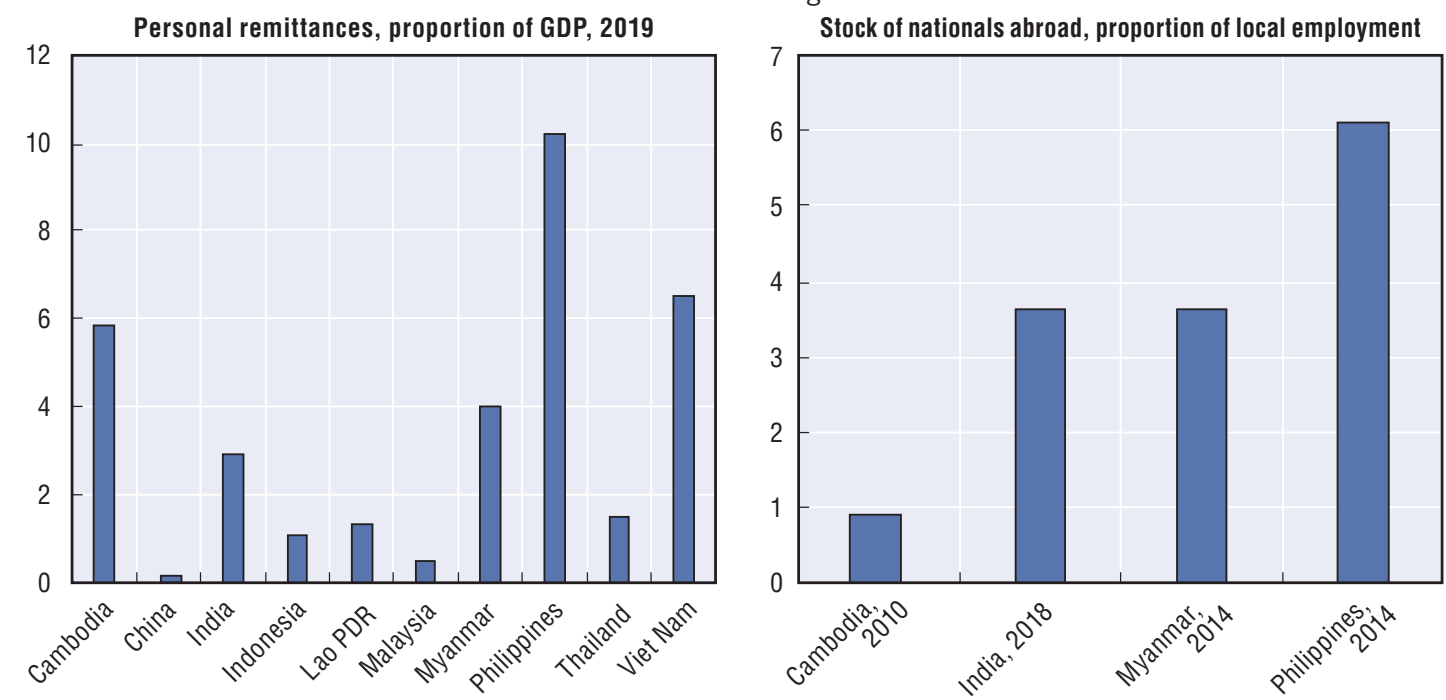

Note: The foreign nationals abroad data and total employment data are from ILO. They do not include sea-based workers. For Myanmar, the foreign nationals data refer to 2014 while the total employment data refer to 2015.

Source: OECD Development Centre based on ILO; World Bank.

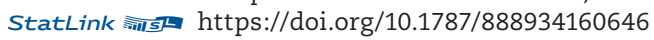

Indications of a healthy trade rebound are also limited. The retention of border restrictions, struggling domestic markets in advanced economies, political distrust among major trading countries and a potential re-escalation of trade tension likewise do not augur well for the cross-border flow of goods. These developments could in turn hamper long-term private investment recovery. Emerging Asian economies generally have room for fiscal manoeuvres, but the space is limited, especially as revenues decline. In certain cases, governments also have to spare funding for natural disasters accompanying the monsoon season and other similar emergencies in the second half of the year.

Against this backdrop, economic output of Emerging Asian countries is projected to decline by $2.9 \%$ in 2020 (Table 1). It is estimated that growth will climb to $6.8 \%$ in 2021 as ground conditions gradually return to normalcy. Southeast Asia's economy as a whole is expected to contract in 2020 by $2.8 \%$ before growth resumes in 2021 . Economic growth patterns in China and India are anticipated to follow the same trajectory. China's economy is expected to contract this year for the first time since the 1970s before GDP growth improves the following year. India's economy will also decline for the first time in more than 40 years and recover in 2021. 
Table 1. Real GDP growth in ASEAN, China and India, 2019-21

Percentage

\begin{tabular}{|c|c|c|c|c|c|}
\hline & 2018 & 2019 & 2020 & $\begin{array}{l}\text { Changes from the previous } \\
\text { forecast (Nov. 2019) }\end{array}$ & 2021 \\
\hline \multicolumn{6}{|l|}{ ASEAN-5 countries } \\
\hline Indonesia & 5.2 & 5.0 & -2.8 & $\downarrow$ & 5.2 \\
\hline Malaysia & 4.8 & 4.3 & -3.9 & $\downarrow$ & 5.9 \\
\hline Philippines & 6.3 & 6.0 & -3.2 & $\downarrow$ & 7.0 \\
\hline Thailand & 4.2 & 2.4 & -6.7 & $\downarrow$ & 4.9 \\
\hline Viet Nam & 7.1 & 7.0 & 2.5 & $\downarrow$ & 7.2 \\
\hline \multicolumn{6}{|c|}{ Brunei Darussalam and Singapore } \\
\hline Brunei Darussalam & 0.1 & 3.9 & 1.4 & $\downarrow$ & 3.3 \\
\hline Singapore & 3.4 & 0.7 & -4.4 & $\downarrow$ & 3.5 \\
\hline \multicolumn{6}{|l|}{ CLM countries } \\
\hline Cambodia & 7.5 & 7.1 & -1.0 & $\downarrow$ & 5.8 \\
\hline Lao PDR & 6.2 & 6.1 & 1.0 & $\downarrow$ & 5.0 \\
\hline Myanmar & 6.4 & 6.8 & 2.0 & $\downarrow$ & 7.3 \\
\hline \multicolumn{6}{|l|}{ China and India } \\
\hline China & 6.7 & 6.1 & -2.6 & $\downarrow$ & 6.8 \\
\hline India & 6.1 & 4.2 & -3.7 & $\downarrow$ & 7.9 \\
\hline Average of ASEAN-10 & 5.3 & 4.7 & -2.8 & $\downarrow$ & 5.6 \\
\hline Average of Emerging Asia & 6.3 & 5.4 & -2.9 & $\downarrow$ & 6.8 \\
\hline
\end{tabular}

Note: Data are as of 26 June 2020. Data for India and Myanmar relate to fiscal years. For Lao PDR, the 2019 GDP growth rate is an estimate. The projections for China, India and Indonesia for 2020 and 2021 are based on the OECD Economic Outlook 107 (database). The projections assume "single hit" scenarios, in which a second big outbreak is avoided. They also assume that world GDP is declining in 2020 but will almost regain pre-crisis level (2016 level) in 2021.

Source: OECD Development Centre.

\section{ASEAN-5}

- Indonesia is still struggling to contain the spread of COVID-19. As private consumption and investment weaken, GDP is forecast to shed about $2.8 \%$ in 2020 in its first contraction since the Asian Financial Crisis. The decline in the growth of private consumption in Q1 2020 was only partly offset by higher government consumption, while the contribution of net exports to GDP also diminished.

- Malaysia has managed to rein in COVID-19 cases steadily since April 2020. Nevertheless, private spending resilience is wavering and export prospects remain downbeat. Malaysia experienced marked declines in net exports and investment in Q1 2020. Against this backdrop, GDP is projected to decline by $3.9 \%$ this year.

- Reigniting business remains challenging in the Philippines due to protracted uncertainty over the extent of COVID-19 cases. Flailing export earnings add to the headwinds for growth. The economy is expected to shrink in 2020 by $3.2 \%$, its first contraction in more than two decades.

- Thailand has navigated the pandemic relatively well, with daily cases of infection steadily declining to single digits since peaking in March. However, the grim tourism and trade outlook weigh heavily on the economy. Real GDP level in 2020 is forecast to come in lower than the previous year by about $6.7 \%$.

- Viet Nam is on track for an exceptional record in public-health crisis management despite the many limitations that the country faces. The considerable dissipation of the health risk has made the environment conducive to a smoother recovery for many firms. GDP growth will slow in 2020 to $2.5 \%$, but the country will continue to lead the ASEAN-5 in this metric. 


\section{Brunei Darussalam and Singapore}

- The comparatively effective COVID-19 management system in Brunei Darussalam allowed the economy to remain partially open even as other ASEAN economies went into strict lockdown. The gradual reversal of the sharp drop in oil prices augurs well for the economy in terms of export earnings and fiscal space. However, with uncertainties in external markets and constraints to fiscal capacity, GDP growth is forecast to roll back to $1.4 \%$ in 2020.

- A second wave of infections has pushed back Singapore's re-opening plans. Robust monitoring and healthcare systems proved to be crucial in keeping social order. Government interventions were similarly helpful in limiting firm closures. Nonetheless, the prevailing weakness in domestic and external demand continues to strain economic prospects. GDP is projected to decrease by $4.4 \%$ in 2020.

\section{Cambodia, Lao PDR and Myanmar}

- Cambodia is weathering the COVID-19 health risks comparatively well, helping to maintain a buoyant domestic economy despite the restrictions. Yet growing risks to exports and friction on investment are set to drag down gross economic production by $1.0 \%$ in 2020 , notwithstanding government assistance programmes. Economic activity is forecast to improve the following year when external uncertainties wane.

- Lao PDR has dealt with the threat of COVID-19 rather well, containing incidents of local transmission of the virus. Keeping risks to domestic labour-market stability at bay augurs well for private consumption. A challenge will be finding markets for the country's electricity exports given the slowdown in industrial activity in the region. The country's GDP is expected to register growth of $1.0 \%$ in 2020.

- The health situation in Myanmar has improved in recent weeks, although security issues in certain areas complicate the response to the health crisis. Easing stress on the growing tourism industry and coping with the wavering export and investment climate are crucial for the economy's stability. Given current conditions, GDP growth is projected to slow to $2.0 \%$ in 2020 .

\section{China and India}

- Notwithstanding new pockets of infection in certain areas, China is on its way to restoring its full economic capacity. Strong growth in technology-based emerging sectors has helped lessen the economic impact of the lockdown and is paving the way for a full rebound in domestic activity. Overall, however, the domestic sector is still groping for balance. And with trade tension still dominating bilateral relations, local production is unlikely to draw as much drive from the external market. GDP is projected to decline by about $2.6 \%$ at the end of 2020 in the economy's first contraction since the 1970s.

- India has become the new epicentre of COVID-19 in Asia, and the government is grappling to reverse the persistent rise in cases. Fiscal limitations and banking sector legacy asset issues compound difficulties in managing the economic risks. Given these factors, the economy is forecast to end fiscal year 2020 (ending in March 2021) in the red. The contraction of about $3.7 \%$ will snap the country's four-decade streak of positive growth. 


\section{Other key points of the economic outlook and assessment}

- The extent of monetary support in major economies effectively ushers in a return to the low-interest rate, high-liquidity environment experienced during quantitative easing. To support the ailing domestic credit market, Emerging Asian economies have ramped up monetary accommodation in a continuation of the policy mix of the previous year (Figure 5).

Figure 5. Monetary policy actions in selected Emerging Asian economies, 2020 Basis points
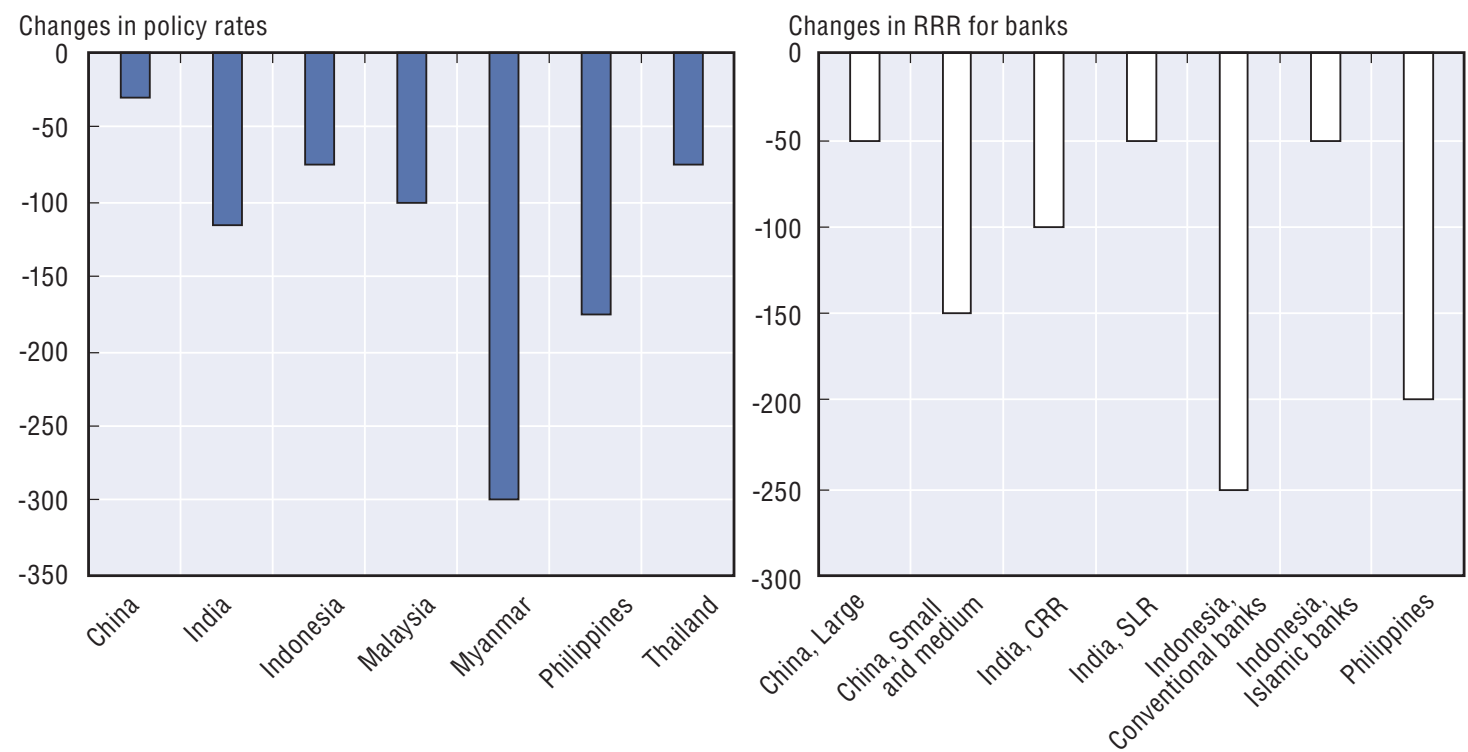

Note: For China, "policy rate" relates to the one-year loan prime rate, and RRR cuts for those small and medium banks in China that specialise in lending to priority sectors are even larger. For India, SLR means statutory liquidity ratio and CRR means cash reserve ratio. For Indonesia, the first local currency RRR cut was announced in December 2019, effective January 2020. In March 2020, Indonesia lowered the foreign currency RRR by 400 bps and the RRR of banks engaged in import and export financing by 50 bps. For the Philippines, RRR covers commercial banks' local currency deposits. The data are from 1 January 2020 to 26 June 2020.

Source: OECD Development Centre calculations based on data from CEIC and national sources.

StatLink 部足 https://doi.org/10.1787/888934160950

- Governments in Emerging Asia have taken drastic measures to finance pandemicrelated spending. The fiscal outlays of ASEAN countries for health services, tax adjustments, subsidies and income support (excluding credit guarantees, money market intervention, direct lending and those with no breakdown) range from less than $0.1 \%$ to approximately $9 \%$ of GDP (Figure 6). In terms of debt, Emerging Asian economies had some fiscal leeway heading into this year, with measured government debt management in the last few years. Nonetheless, the sheer spending requirements needed to maintain social order and help the real economy regain its pre-pandemic health will test fiscal capacity. 
Figure 6. Total amount of fiscal packages and estimated impact on the fiscal balance of selected Emerging Asian economies

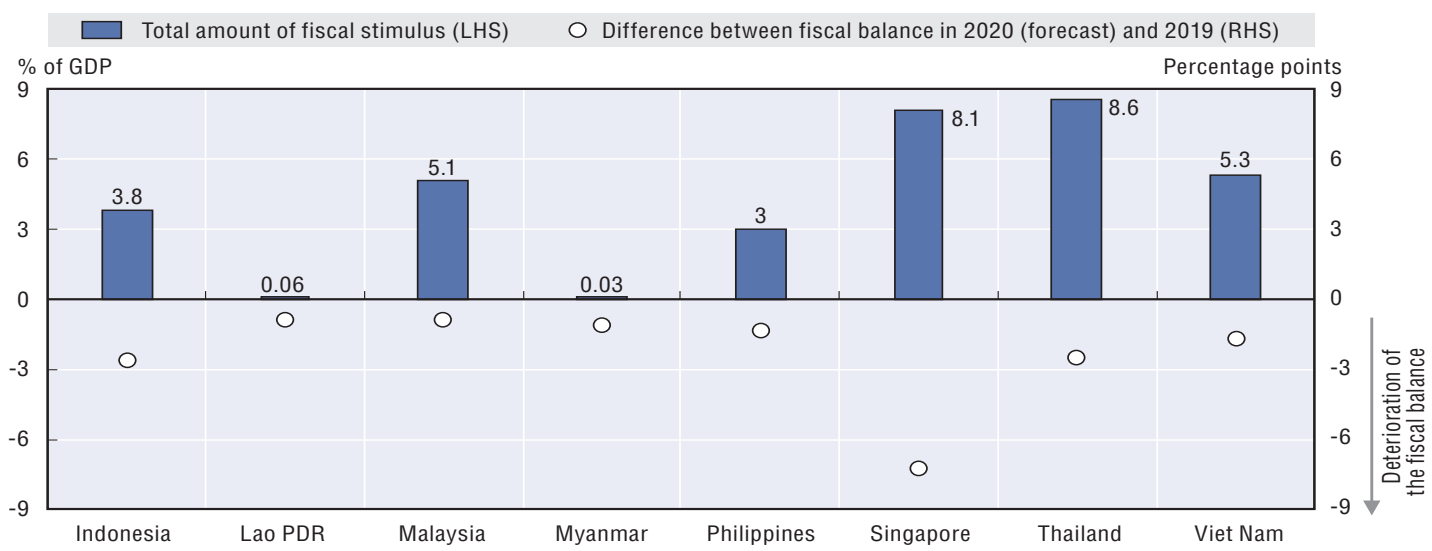

Note: The cut-off date for the fiscal stimulus data is 15 June 2020. Data refer to the general government.

Source: OECD Development Centre based on: ADB (2020), ADB COVID-19 Policy Database; IMF (2020a), World Economic Outlook Database, April 2020; and the World Bank national accounts dataset.

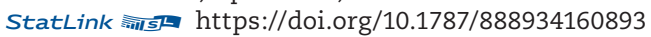

- The collapse in economic activity led to both demand- and supply-side pressures in Emerging Asian countries. The aggregate effect of the COVID-19 crisis on inflation is therefore rather difficult to gauge and will depend on how these two forces balance out. Headline inflation in the region has moderated overall. At the same time, low global oil prices, which weighed on overall inflation at the beginning of the year, are on an upward trend. The aggregate figures may nevertheless hide differences at the sectoral levels.

- The flood of liquidity into global financial markets could have repercussions on the volatility of cross-border hot capital flows over the course of a few quarters. The ability to keep macroeconomic fundamentals sound during the recovery process will be essential for smoothing cross-border capital movement. Emerging Asian currencies have mostly weakened vis-à-vis the US dollar, reversing the 2019 trend.

- Corporate earnings are under heavy fire as the real sector reels from the impact of COVID-19. Grim expectations on corporate performance pushed bellwether indices to multi-year lows in the first four months of 2020. Yet hopes brought by the partial re-opening of economies have led equity prices higher since they bottomed out in the March-April period.

- The current account balances of the region's economies are expected to weaken in the coming quarters. Tight border restrictions for shipments will continue to dampen cross-border trade. The risk of revived trade tension could complicate the environment. Furthermore, remittances from foreign workers are expected to weaken significantly in the next few quarters, with many layoffs unlikely to be reversed in the short term.

\section{Policy priorities in response to COVID-19 in Emerging Asia}

The COVID-19 crisis demonstrated the importance of digitalisation, which became imperative during confinement to guarantee the continuity of essential services. Looking forward, policy makers need to maximise the use of digital tools while at the same time ensuring cyber resilience. In the tourism sector, which was badly affected, emergency support measures need to be supplemented with a more holistic longer-term strategy. 
The health sector needs policies not only to curb the spread of the virus, but also to prepare healthcare systems for potential future outbreaks. Regional initiatives to deal with the pandemic and its effects are currently underway and need to be strengthened going forward.

\section{Surging demand for digital tools creates an opportunity for Emerging Asia}

The COVID-19 crisis will negatively impact almost the entire commercial sphere in 2020. However, the crisis triggered by the outbreak will also lead to lasting transformations and should benefit certain sectors, starting with technology and firms that enable online and technology-based services. Indeed, the health crisis pushed employees, households, businesses and students into a digital world. Digitalisation allowed telework and online platform applications to proliferate while people were confined to their homes. Demand for digital work applications and non-professional applications ramped up as lockdown measures took effect globally. These include applications to assist business continuity and online learning, and to provide households with alternative solutions, including online transactions more generally. New telemedicine online platforms were also introduced.

A massive increase in video conferencing is one of the most conspicuous adaptations. This technology proved to be the ultimate solution for remotely connecting personnel, customers, teachers, students, friends and family during the lockdown. Telework expanded as most Emerging Asian countries took action to slow the spread of the virus. Under a lockdown order issued in Lao PDR in March, for example, all government officials were required to work from home. In Indonesia, the government encouraged companies to adopt work-from-home arrangements, and some employees over 50 years of age at stateowned enterprises were asked to work from home beginning in mid-March. However, telework was complicated in some countries by inadequate Internet access and speed.

\section{People turn to online health and education sites}

The use of online medical apps increased sharply during the pandemic, with people relying on these applications for information about COVID-19 outbreak and methods for preventing the disease. This helped to expand awareness about COVID-19, especially regarding the extent of transmission and the progress of its spread. The surge was particularly notable in China. The crisis also demonstrated the need to increase healthcare spending, and this will benefit corporations in the biotechnology and medical equipment sectors, as well as pharmaceutical groups. Traditional healthcare is powered by technology, with robots and other technologically-advanced tools deployed to evaluate patients' condition and monitor the spread of the virus.

The closing of schools and educational institutions around the world, meanwhile, sparked increased use of digital online learning tools to allow continuity of education while children and educators were confined to their homes. In China, the usage of online education platforms increased by $22 \%$ during the outbreak compared to the same period in the previous year, and people spent $30 \%$ more time using these digital platforms. The use of online digital platforms by the education industry surged by $17.5 \%$ year-on-year, a larger increase than for the online shopping or video industry.

Insufficient technological capacity can hinder the use of digital tools for education and other purposes, and the problem is likely to persist in emerging economies with limited information technology infrastructure and Internet availability. Affordability of online services is another issue confronting ASEAN countries. In some Emerging Asian countries, online education infrastructure remains weak, with large-scale remote 
education mainly provided via television and radio. To meet increased demand for digital learning, improved Internet access and digital education platforms are urgently needed.

\section{Demand rises for cloud hosting, smart home technologies and digital payment}

COVID-19 resulted in increased demand for cloud-based business tools and services - computing services, cloud database management and virtual servers - to sustain business functions while employees were working remotely. In April 2020, Emerging Asian economies recorded extraordinary growth in cloud hosting revenue, with China (47.1\%) and India (38.5\%) displaying the largest increases. Software solutions and development applications have similarly seen an upturn in use. In particular, Indonesia and China posted positive growth in software solutions revenue in April 2020, at $15.7 \%$ and $14.6 \%$ respectively, while India and Viet Nam saw growth rates below 5\% (Figure 7).

Figure 7. Rise in cloud hosting and software solutions revenue April 2019 to April 2020, percentage y-o-y

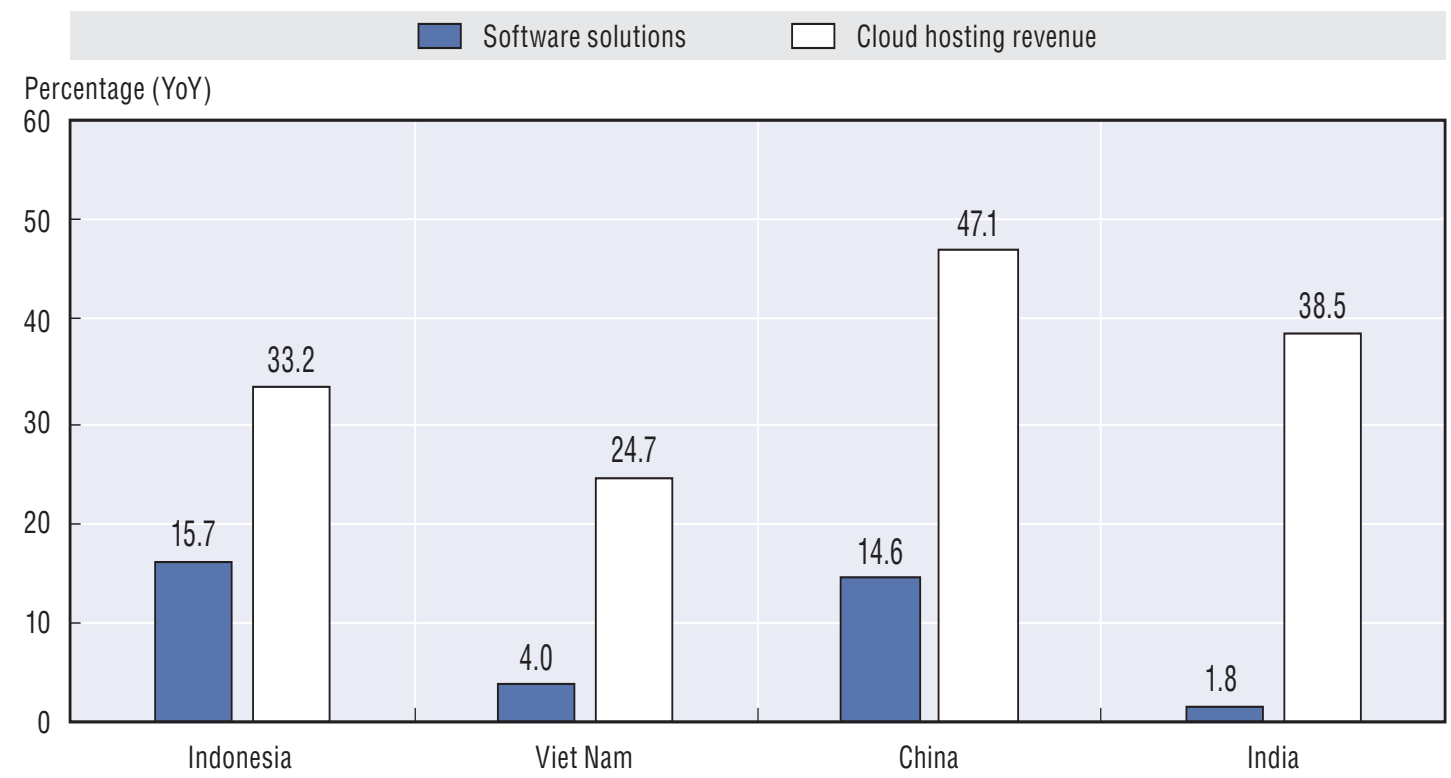

Note: The cloud hosting market represents third-party cloud service providers who deliver computing resources such as servers and storage over the Internet to their customers. This excludes dedicated single-purpose solutions such as ERP and CRM. Company examples include Amazon Web Services, Microsoft Azure, Google Cloud, and IBM. The software solutions market includes Productivity Software, Enterprise Software as well as System Infrastructure Software and Application Development Software. The majority of software solutions in these market segments are designed to be used in a professional environment but may also be used privately. Company examples include Microsoft, Citrix, SAP, and Adobe.

Source: Statista.

StatLink 䣓D https://doi.org/10.1787/888934161216

Along similar lines, "smart home" technologies have grown in response to health insecurity and stay-at-home orders. Other than Singapore, which established home automation prior to COVID-19, all Emerging Asian countries posted significant growth in smart home users in April 2020 year-on-year, in particular the Philippines (60.0\%), Cambodia (58.5\%), Lao PDR (59.8\%), and Myanmar (61.3\%).

Furthermore, although retail closures, travel bans and reduced discretionary spending due to the COVID-19 pandemic negatively impacted some sectors, online transactions via various payment methods have seen a recent surge in both revenue and users. Among Emerging Asian economies, Cambodia, Lao PDR and Myanmar posted annual growth of 
20\% in e-commerce users in April 2020 compared to the previous year. Although CLM countries have seen a spectacular rise in the number of users, the average amount spent per user was lower than elsewhere in the region, as illustrated by the lower transaction revenues in the former. In terms of transaction revenue, the highest growth in digital commerce sales and revenue was recorded in China (24.9\%), Indonesia (24.4\%) and India $(23.2 \%)$. Acceleration in the adoption of digital payment technologies also occurred in Malaysia, the Philippines, Thailand, Viet Nam, Singapore and Cambodia, well ahead of Brunei Darussalam, Lao PDR and Myanmar. Two big drivers of digital commerce are the emergence of smartphones and the fast growth of the Internet-connected population.

The pandemic also brought an increase in e-banking as banks encouraged customers to conduct transactions electronically to reduce the risk of transmitting the virus. For example, the volume of e-banking transactions in Viet Nam rose by $26 \%$. In the Philippines, the lockdown measures also resulted in a sharp increase in registrations for Internet banking services. A comparison of transaction statistics in March 2020 before and after the lockdown shows that the transaction value of digital banks soared by $633 \%$ and that the number of transactions rocketed by $416 \%$.

\section{Further facilitating digitalisation is crucial in the region}

Cloud computing, digital commerce, e-learning platforms, and medical and shopping applications presented an opportunity for countries to make economic gains during the COVID-19 pandemic, while affordable smartphones and the rise of mobile Internet penetration led to momentum in e-commerce activities. Efforts to mobilise digital innovations remain limited in some emerging countries, especially those with insufficient IT infrastructure and Internet availability.

There are various barriers to the growth of digital technology in the region. When available, Internet connectivity mostly takes place through mobile broadband rather than through higher-speed fixed broadband. Investment is needed to upgrade Internet infrastructure and improve bandwidth. To help cover large capital expenditures, publicprivate partnerships could be envisaged.

Digital skills need strengthening in the region. Increased awareness of digital opportunities could help firms, especially micro, small and medium enterprises (MSMEs), to enhance productivity and increase their presence on global marketplaces. Targeted strategies could be envisaged to assist the corporate sector at large, and lagging sectors in particular, to increase their digital footprint.

Digital payment tools are underused. In order to encourage this payment method, digital payment tools should be made easier to use, the speed of online transfers improved and obstacles (such as barriers to small payments) removed. Customers should be adequately informed, while merchants should be supported to acquire payment terminals. Customers' trust in the integrity of digital payment tools is essential. Fraud prevention mechanisms should be strengthened, in particular where authentication criteria for electronic payments and online transfers are still weak.

With sharp growth in online activities in the current unprecedented situation, a cyber incident that blocks access to the Internet could have severe implications. In an undesirable scenario, a major cyber incident could obstruct business operations, online education and healthcare providers, as well as public systems and networks. It is therefore imperative for Emerging Asian economies to implement strategies that allow firms, individuals and communities to continue operating normally in the event of cyber disruptions. 


\section{Travel and tourism are suffering a major blow under COVID-19}

Tourism and travel were among the sectors worst impacted by COVID-19 in Emerging Asia. Travel restrictions were imposed in all countries, though the scope, stringency and enforcement of these restrictions varied. The declines in visitor arrivals closely mirror countries' policy approaches in terms of regulating international flows, which have evolved from screening and/or temporary quarantine initially to bans or even border closures as the health crisis unfolded (Figure 8).

\section{Figure 8. Visitor arrivals plummeted as restrictions on international travel tightened}

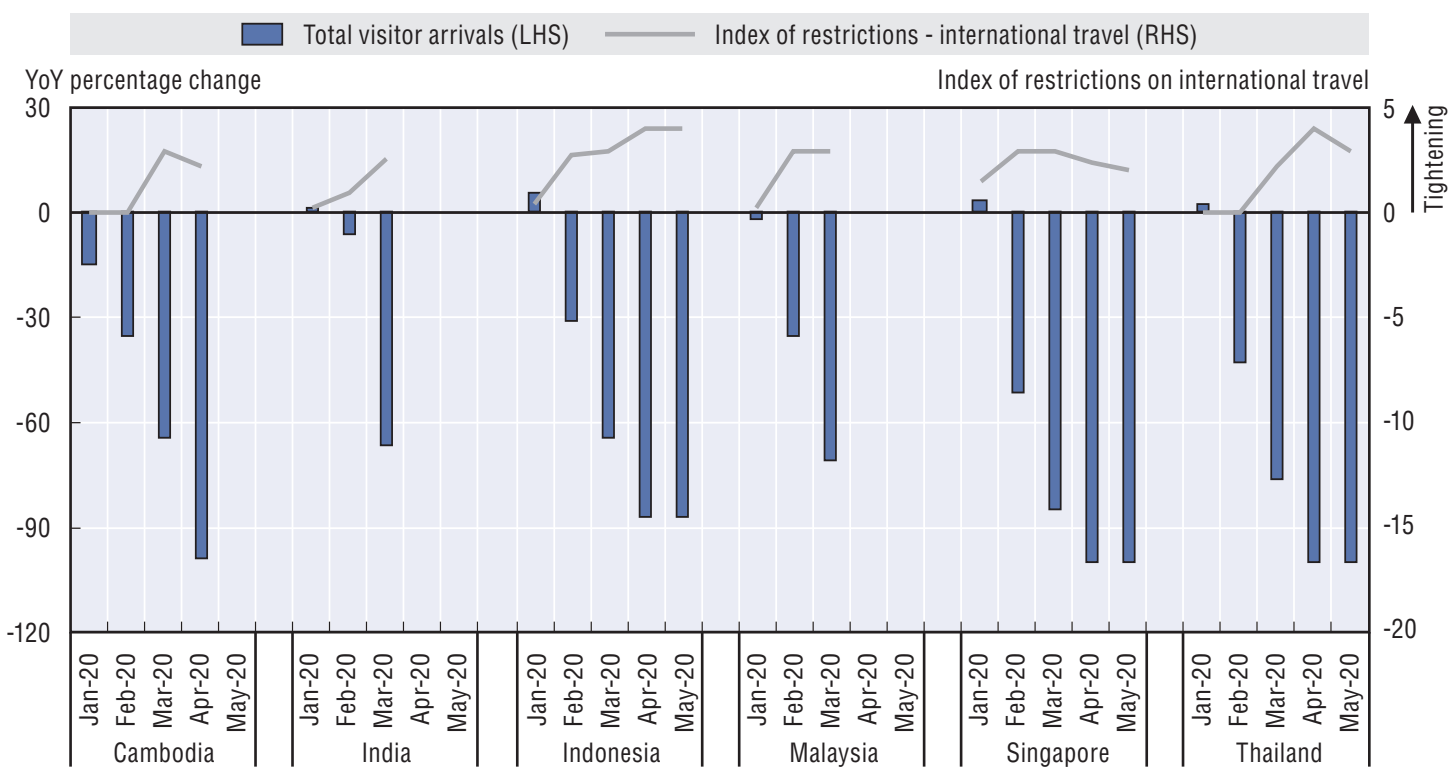

Note: The index of restrictions on international travel is defined on a scale between 0 and 4, as follows: 0 ) no measures; 1) screening; 2) quarantine for arrivals from high-risk regions; 3) ban on arrivals from some regions; 4) ban on all regions or total broader closure. The index is reported on a daily basis; the monthly value represents the average of daily values for the respective month.

Source: OECD Development Centre based on data from CEIC and Oxford COVID-19 Government Response Tracker.

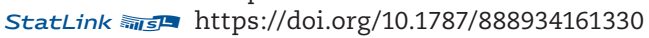

A subsector of tourism that has been heavily impacted by COVID-19 is meetings, incentives, conferences and exhibitions (MICE), which represents corporate or professional meetings held abroad, often in prime tourist destinations, including in Emerging Asia. These gatherings, which may mix business and leisure, are usually planned months or years in advance. As MICE events are typically large indoor gatherings and therefore present an elevated risk of viral transmission, the sector needs to adapt. This may involve caps on event sizes, increased use of remote conferencing and changes to activities and dining. MICE bookings will need to introduce flexible cancellation options due to the risk of future outbreaks of COVID-19 in destination or home countries.

Several Emerging Asian countries implemented fiscal packages to support workers in travel and tourism sectors during the period of restrictive measures. Policies are crucially needed to protect vulnerable workers, many of whom are informal workers lacking access to insurance or relief schemes. Worker compensation is also needed for the reduction in demand for services and guarantees of income in the event of illness. 
With many national borders closed, countries including Indonesia, Malaysia and Thailand have sought to stimulate domestic tourism to keep tourism-related businesses operating and workers employed.

With public health conditions evolving rapidly, co-ordination among tourism officials, health officials and local authorities at domestic tourist destinations could be helpful towards developing and implementing a response to potential future outbreaks. Tourist attractions that draw dense crowds may become epicentres of infection, and containment measures must be swift. Contact tracing, including logging of visitors, will play a vital role, and safety measures like physical distancing and masks need to be in place. Ensuring that staff in tourist attractions are not sources of COVID-19 is also needed.

\section{Countries scramble to update health policies to deal with the pandemic}

The COVID-19 pandemic has shown the need for countries worldwide to update their health policies. Areas of focus include the development of tracing methods, the use of education to promote better hygiene and the need for more medical personnel and healthcare facilities. International co-operation is proving crucial in the effort to develop a vaccine, and countries in Emerging Asia are assisting each other to control the spread of the virus through donations of supplies.

Thorough contact tracing using epidemiological surveys and control measures is vital for containment. In an epidemiological survey, patients' previous whereabouts are ascertained via interview and electronic means (as necessary and if available). Based on this information, people exposed to an infected person may be required to self-quarantine and monitor symptoms. The mobile application aspect of this model has potential in most ASEAN countries, since all but Lao PDR have mobile penetration rates above the world average.

Data security is a concern in both contact tracing and general health information. Contact tracing applications rely on movement tracking, raising concerns over who has access to that information and other potential uses for it. Anonymising the data becomes difficult in sparsely populated areas or for people who have strict routines. Proximity-based analysis may also overestimate exposure risk. Phishing is a potential hazard, as malicious actors are able to make illegitimate copies of applications easily. Ensuring data security and privacy is crucial.

Promotion of personal hygiene is another critical aspect of controlling the spread of COVID-19. As the virus is primarily transmitted through droplets or transfer from surfaces, physical distancing, handwashing and coughing etiquette help to break the chain of transmission. Physical distancing may be enforced privately through voluntary co-operation or by businesses adjusting their operating procedures to prevent crowding, or via government order. Handwashing is also essential for suppressing transmission, but this remains challenging in areas where proper handwashing is not a common practice and where dwellings do not have clean running water. Providing information and education is therefore crucial, and soap or alcohol-based hand cleanser should be provided for those who do not have access.

\section{Emerging Asia grapples with shortages of medical equipment and staff}

Shortages of medical supplies and healthcare workers, which exist in most Emerging Asian countries, become particularly noticeable during a pandemic. The shortages include physical capital, such as medicine, equipment, care facilities and personal protective equipment (PPE) for healthcare workers and the general population, and human capital, including doctors, nurses, medical technologists and medical educators. Since the pandemic began, some countries have amended or expanded their government budgets 
to purchase more supplies and equipment, while others received donations from foreign governments or private individuals.

Every ASEAN country has fewer hospital resources per capita than the OECD average. The number of doctors and nurses per unit population is below the OECD average in each country. Physical infrastructure also matters in the fight against COVID-19. The countries with fewer beds per capita also exhibit the highest COVID-19-related mortality rates in Emerging Asia (Figure 9).

\section{Figure 9. Hospital beds and COVID-19 mortality in selected} Emerging Asian economies

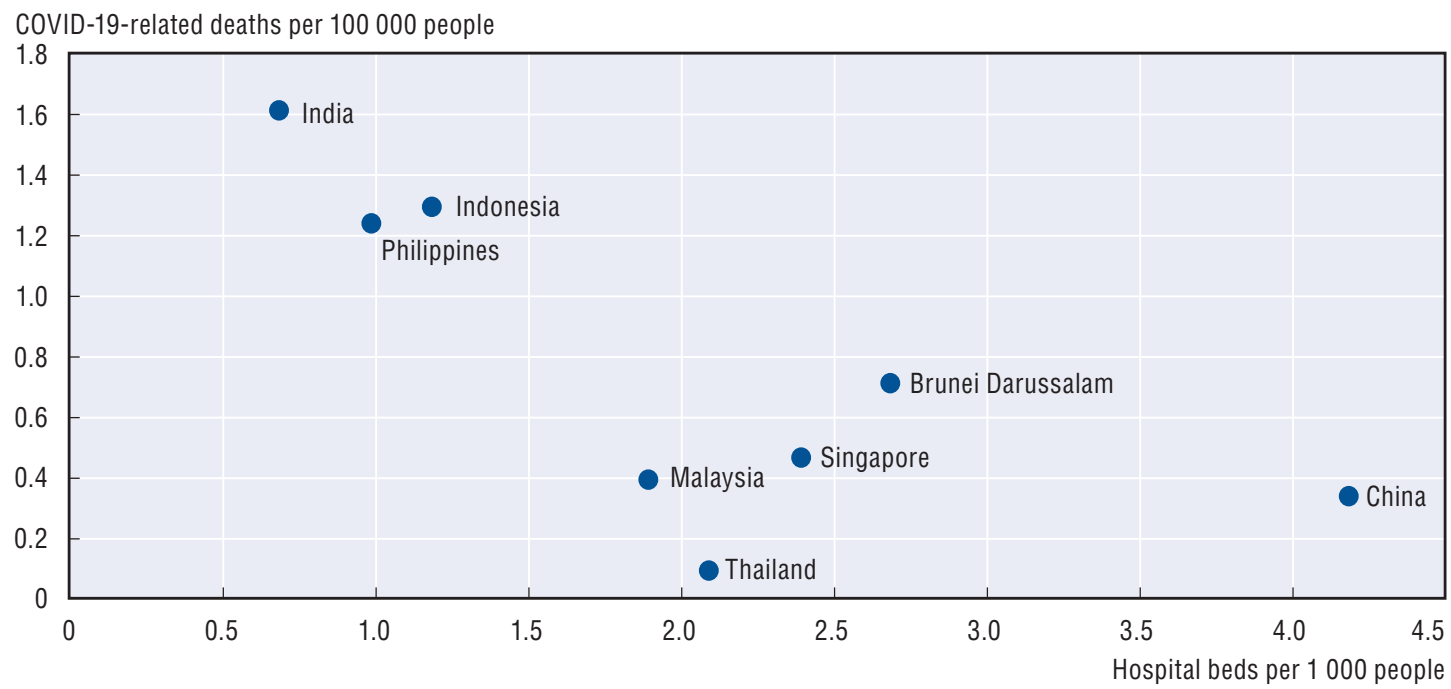

Note: Cumulative number of COVID-19-related deaths as of 10 July 2020.

Source: OECD Development Centre based on data from Johns Hopkins University and the World Bank World Development Indicators.

StatLink (inilst https://doi.org/10.1787/888934161406

ASEAN countries need to improve their medical systems. In the short term, existing resources could be mobilised. For instance, retired physicians and nurses could be recruited to ease the personnel shortage. Long-term efforts to improve the medical workforce should focus on education. Proper incentives are needed for students to complete the long educational process required to become a nurse or physician. Improving the quality of education at medical schools in the region is essential, and students who train abroad must be able to benefit from returning home. Starting and scaled wages should reflect training quality, and healthcare funds must be allocated to developing infrastructure and training staff to operate it.

Given the highly contagious nature of COVID-19, long-term hope for controlling the virus rests in a vaccine. International co-operation is currently taking place in research and development of vaccines. Along with this global effort, mass-production facilities must be prepared rapidly to ensure a smooth transition from approval of a vaccine to availability. Public health authorities should maintain a register of vulnerable persons who need the vaccine urgently. These include front-line healthcare workers, the elderly and people with pre-existing medical conditions.

\section{Emerging Asia strengthens collaboration to fight the pandemic}

Emerging Asian countries quickly recognised the need to strengthen collaboration and co-operation to combat the pandemic. Since the first COVID-19 cases were reported in 
January, leaders in ASEAN and China, Japan and Korea have stepped up efforts to provide a collective response. Region-wide initiatives are being implemented to support national measures, in particular within the framework of ASEAN and ASEAN Plus Three (Table 2). The initiatives, particularly those related to the health sector, involve facilitating and maximising the use of existing forms of co-operation.

\section{Table 2. Examples of region-wide pandemic initiatives in ASEAN} and ASEAN Plus Three

\begin{tabular}{|c|c|}
\hline Initiative & Programmes \\
\hline $\begin{array}{l}\text { Establish a COVID-19 ASEAN Response } \\
\text { Fund }\end{array}$ & $\begin{array}{l}\text { Supporting the provision of medical supplies and equipment and preventive efforts in all } \\
\text { member states }\end{array}$ \\
\hline Strengthen co-operation in public health & $\begin{array}{l}\text { Exchanges of information and sharing of experience and best practices in research and } \\
\text { development of vaccines and anti-viral medicines, in clinical treatment and in enhancing the } \\
\text { capacity of public health systems and response to pandemics }\end{array}$ \\
\hline $\begin{array}{l}\text { Run an information platform among ASEAN } \\
\text { Member State officials working at crisis } \\
\text { centres and/or disease prevention and control }\end{array}$ & $\begin{array}{l}\text { The ASEAN Emergency Operations Centre Network for public health emergencies runs a } \\
\text { platform to share timely information, including on newly confirmed cases and national } \\
\text { measures, through channels including social media platforms, WhatsApp, websites, etc. }\end{array}$ \\
\hline $\begin{array}{l}\text { Assess risks through the ASEAN } \\
\text { BioDiaspora programme }\end{array}$ & $\begin{array}{l}\text { Real-time web-based risk assessment tools linking multiple datasets, including air travel } \\
\text { data, demography data, human population density, animal populations, industrialisation } \\
\text { and utility distribution, vector locations and other relevant information }\end{array}$ \\
\hline $\begin{array}{l}\text { Strengthen scientific co-operation in } \\
\text { epidemiological research }\end{array}$ & $\begin{array}{l}\text { Strengthening scientific co-operation in epidemiological research including through } \\
\text { the ASEAN+3 Field Epidemiology Training Network, co-ordination on rapid research, } \\
\text { development, manufacturing and distribution of diagnostics, anti-viral medicines and } \\
\text { vaccines, adhering to the objectives of efficiency, safety, equity, accessibility and } \\
\text { affordability and actively sharing and leveraging digital technologies and innovation to } \\
\text { promote a science-based response to combat COVID-19 }\end{array}$ \\
\hline $\begin{array}{l}\text { Enhance co-operation in trade and } \\
\text { investment }\end{array}$ & $\begin{array}{l}\text { Reaffirming commitments to keep markets open for trade and investment, enhancing } \\
\text { co-operation on food security among ASEAN+3 countries, such as the utilisation of } \\
\text { the ASEAN Plus Three Emergency Rice Reserve, and strengthening the resilience and } \\
\text { sustainability of regional supply chains, especially for essential goods such as food, } \\
\text { commodities, medicine and medical supplies }\end{array}$ \\
\hline
\end{tabular}

Source: OECD Development Centre's compilation based on various official statements.

ASEAN has also organised ministerial meetings in response to the pandemic. On 19 February, ASEAN defence ministers met in Viet Nam and issued a joint statement on co-operation against COVID-19. In March, ASEAN ministers held a retreat in Viet Nam and agreed to take collective action to mitigate the economic impact of the pandemic, such as:

- keeping ASEAN markets open for trade and investment

- strengthening regional information sharing, co-ordination and collaboration in responding to economic challenges

- working closely with industries to encourage confidence in Southeast Asia as a trade and investment hub and tourism destination

- leveraging technologies and digital trade to allow businesses, especially MSMEs, to stay afloat amid the outbreak

- strengthening long-term supply-chain resilience and sustainability, in particular by implementing the Master Plan on ASEAN Connectivity 2025

- enhancing economic co-operation with external and development partners to include initiatives aimed at strengthening regional supply chains

- building on existing trade facilitating platforms, such as the ASEAN Single Window, to promote and support supply-chain connectivity

- refraining from actions that could create unnecessary inflationary pressures or adversely impact food security 
- ensuring the availability of basic goods and commodities

- continuing to address non-tariff barriers, particularly those that impede the smooth flow of goods and services in supply chains.

More recently, the $36^{\text {th }}$ Annual ASEAN Summit was held virtually on 26 June, presenting an opportunity for leaders of ASEAN Member States to reaffirm and flesh out their commitment to regional co-operation, especially in the context of COVID-19. Strengthening ASEAN health security was noted as a top priority and it was acknowledged that public health emergency responses must be co-ordinated not only within ASEAN, but also between ASEAN and its dialogue partners. Such efforts could take the form of collaborative scientific research, assistance in the development and procurement of vaccines and medicines, strengthening of medical and non-medical supply chains, as well as navigating a safe and robust economic recovery. The importance of improving synergy among regional frameworks, such as ASEAN Plus One, ASEAN Plus Three, East Asia Summit, was also stressed.

\section{Region-wide initiatives tackle information sharing and risk assessment}

In the health sphere, ASEAN ministers agreed to enhance the timely exchange and sharing of COVID-19 data and information, including prevention, detection, control and response measures, epidemiologic surveillance updates, risk assessment results, epidemiological and clinical studies on the virus and the disease, and technical guidelines, through existing ASEAN health sector co-operation mechanisms. They also agreed to strengthen co-operation in risk communication, to work together to prevent misinformation and fake news, and to maximise the use of digital technology for efficient exchange of information. Other areas of agreement included: co-ordination of public health responses such as contact tracing; enhanced co-operation in capacity building on public health emergency preparedness and response; and continued collaboration in learning from regional and national experiences.

Collective initiatives are also being implemented in the areas of risk assessment, readiness and response planning through the ASEAN BioDiaspora programme. As a realtime and web-based risk assessment tool, it links multiple datasets including air travel data, the demography data of ASEAN Member States, human population density, animal populations, industrialisation and utility distribution, vector locations, among others. The ASEAN BioDiaspora Regional Virtual Centre produces risk assessment reports pertaining to COVID-19, with highlights and a situational overview of the epidemic, a timeline of international dissemination, a public health outlook and the risk of importation through air travel. It also provides information on cases and fatalities related to COVID-19 and travel advisories among ASEAN Member States in response to the epidemic.

The Asia-Pacific Economic Co-operation (APEC) forum is also being used for collective initiatives on the pandemic. In May, the ministers responsible for trade in APEC economies issued a statement pledging to work together towards mitigating the health and economic impact of COVID-19. They committed: to facilitate the flow of goods and services across borders, including medicines, medical supplies and equipment, agricultural and food products, and other supplies; to minimise disruptions to global supply chains; and to work closely on identifying and resolving any unnecessary barriers to trade. Considering the importance of the digital economy amid the pandemic, the countries also stated their commitment to strengthen APEC's digital agenda, including e-commerce and related services. 
Many of the initiatives aimed at enhancing co-operation at the regional level focus on exchanging information and sharing experiences and best practices among member countries. While this is crucial, other initiatives, such as financial co-operation, need to be strengthened. Collective responses that focus on the health sector are unquestionably necessary, yet the pandemic is also having a socio-economic impact on other sectors, including tourism, hospitality, financial markets, the banking sector and manufacturing. There is thus a need to broaden the coverage of region-wide initiatives. Countries will need to ensure that responses to both current and future outbreaks are timely and effectively co-ordinated. These responses should be longer-term and forward-looking to increase the region's resilience and better prepare for future pandemics.

\section{Boosting education quality in Emerging Asia: Recommendations from PISA 2018}

The spread of COVID-19 left many learners across the globe out of school, at least temporarily. While learning has continued in one way or another, the consequences of the school closures have been particularly damaging for vulnerable students. Unfortunately, vulnerable students tend to have fewer of the resources required for learning at home, such as: access to digital resources and a quiet place to study; motivated, supportive and highly skilled parents and teachers; and the ability to learn autonomously. While the full consequences of the school closures cannot yet be evaluated, the results of the Programme for International Student Assessment (PISA) 2018 can provide a valuable reference point for education systems.

Some education systems in Emerging Asia have a long tradition of participating in the PISA assessments, while others only started participating in 2018. All countries and economies in PISA participate in the reading, mathematics, and science assessments. In addition, PISA offers the possibility of assessing financial literacy, and each cycle explores a new "innovative domain" such as problem solving (PISA 2012), collaborative problem solving (PISA 2015) and global competence (PISA 2018). In PISA 2018, Brunei Darussalam, Indonesia, the Philippines, Singapore and Thailand took part in the global competence assessment, and only Indonesia evaluated financial literacy.

All countries and economies in PISA 2018 distributed the student and school questionnaires. PISA 2018 also offered: four optional questionnaires for students (on educational career, ICT familiarity, well-being and financial literacy); an optional questionnaire for parents; and an optional questionnaire for teachers (both for reading teachers and for teachers of all other subjects). In the region, Brunei Darussalam and Thailand distributed the educational career questionnaire; Brunei Darussalam, Singapore and Thailand distributed the ICT questionnaire; and Malaysia distributed the teacher questionnaire.

\section{Performance in reading, mathematics and science}

Indicators of math, reading and science performance place most of the education systems in Southeast Asia clearly below the OECD average and the average of neighbouring economies such as Beijing, Shanghai, Jiangsu and Zhejiang (B-S-J-Z) (China) and Chinese Taipei (Figure 10). 
Figure 10. Performance in reading, mathematics and science

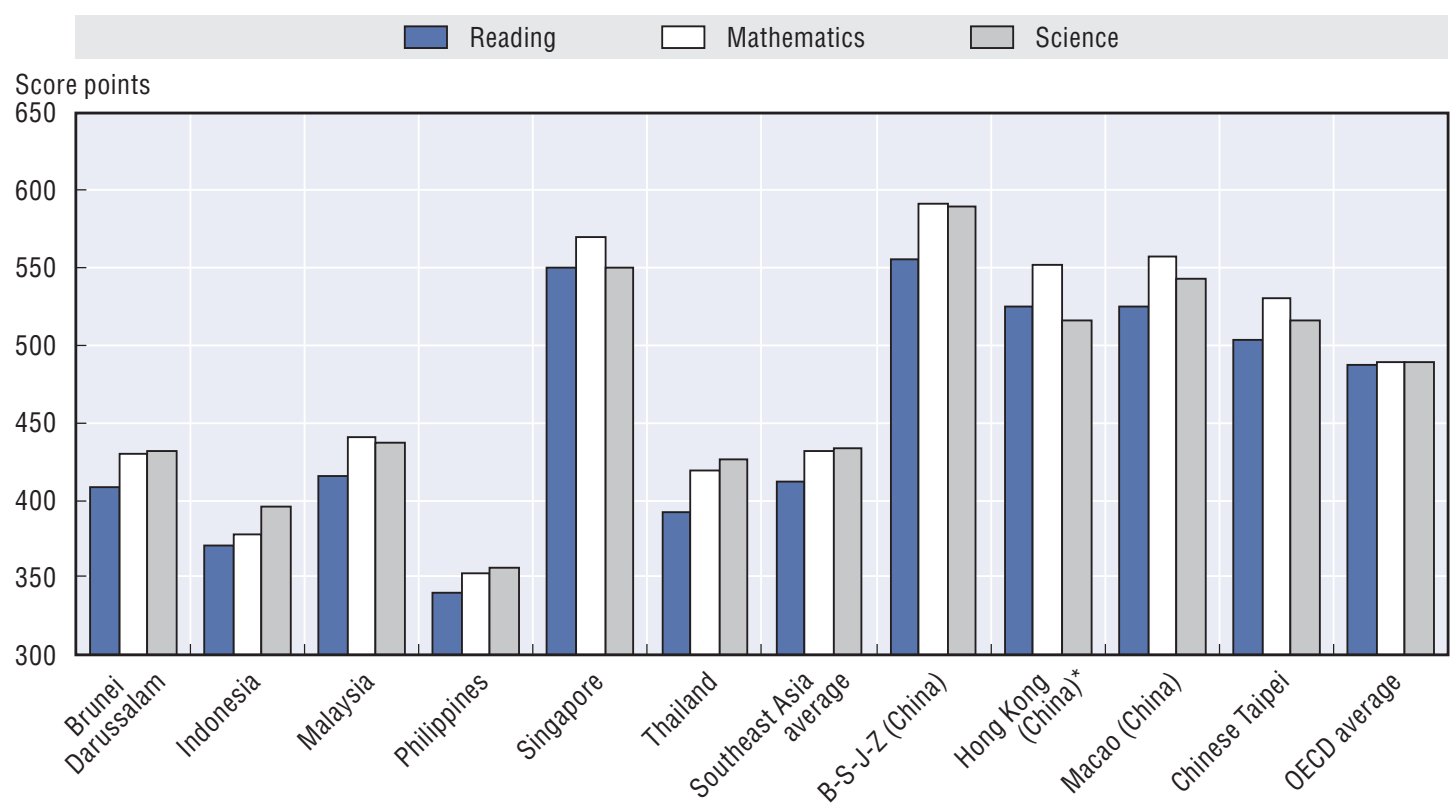

Note: * PISA 2018 data did not meet the PISA technical standards but were accepted as largely comparable. Source: OECD, PISA 2018 Database, Tables I.B1.4, I.B1.5 and I.B1.6.

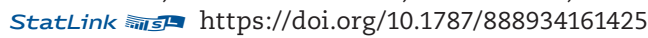

However, Southeast Asia's average hides wide differences among school systems. With average scores at least half a standard deviation above the OECD average, Singapore was one of the top-performing school systems in PISA 2018. Malaysia was the second highest-performing country in the region, followed closely by Brunei Darussalam and Thailand, and then by Indonesia and the Philippines.

As in previous cycles, the reading scale for PISA 2018 was divided into a range of proficiency levels whose descriptors were updated to reflect new aspects of reading that were assessed for the first time, such as assessing the quality and credibility of information and managing conflict among texts. Approximately $47 \%$ of students across Southeast Asia scored above the baseline level of proficiency in reading, ranging from $19 \%$ of students in the Philippines to $89 \%$ in Singapore. In comparison, $77 \%$ of students on average scored above the baseline level across OECD countries, $82 \%$ in Chinese Taipei and $95 \%$ in B-S-J-Z (China). Better results were observed for mathematics and science, where $50 \%$ and $54 \%$ of students, respectively, scored above the baseline level of proficiency across Southeast Asian economies.

Students' performance in mathematics and science is particularly important in the context of digitalisation and ICT-related training and studies. Demand for ICT skills is growing in the region, and those who have these skills are earning higher wages. Good performance in science, technology, engineering and mathematics (STEM) will therefore be needed in Emerging Asian countries to ensure their ability to integrate the global economy, especially in the digital era.

\section{Trends in performance, gender differences and the socio-economic divide}

Indonesia has seen no significant long-term changes in students' performance in reading, mathematics and science. In reading, Indonesia belongs to the group of countries with a hump-shaped trajectory, with performance improving during the first years since inception of its participation in the PISA assessments, and becoming more negative in more recent years. Malaysia has significantly improved in mathematics and science 
throughout its participation in PISA, but has shown no significant change in reading. Since Thailand's first participation in PISA, mathematics and science performance have remained stable, while the average reading performance has dipped. In reading, Thailand is in the group of countries with an increasingly negative trajectory, together with Korea and the Netherlands. Singapore, already a top-performing education system when it first participated, has improved its performance in reading and science even further.

In terms of gender differences, PISA results in recent decades have consistently found on average that girls outperform boys in reading and, to a lesser extent, that boys outperform girls in mathematics, across all participating countries and economies. Gender disparities in achievement are a matter of considerable concern, as they may have long-term consequences for girls' and boys' personal and professional future.

On average across Emerging Asian countries, the gender gap in reading performance, where girls outperform boys, was 28 score points, similar to the gender gap across OECD countries (30 score points). The gender gap in reading performance varied little among Southeast Asian countries (between 23 and 30 score points), except in Thailand where it stood at 39 score points. Interestingly, one of the narrowest gender gaps in reading performance across all PISA-participating countries and economies was observed in B-S-J-Z (China), where girls outperformed boys by only 13 points.

Long-standing research finds that the most reliable predictor of a child's future success at school - and, in many cases, of access to well-paid and high-status occupations - is his or her family. However, results from previous rounds of PISA suggest that school systems may be able to help mitigate the impact of families' socio-economic status on their child's life outcomes.

PISA consistently finds that some education systems manage to attain both academic excellence and equity. Among the 25 school systems that scored above the OECD average in reading, about half exhibited positive equity outcomes, including those in Australia, Canada, Estonia, Finland, Japan, Korea, Norway and the United Kingdom. Unfortunately, no education system in Southeast Asia attains both academic excellence and equity, and some (Brunei Darussalam, Malaysia and the Philippines) scored in the least desirable quadrant, where both academic performance and equity are below the OECD average.

PISA 2018 measured the allocation of material and human resources to schools by asking school principals the extent to which their capacity to provide instruction in their schools was hindered by a lack or insufficient quantity of the following resources: education staff, assisting staff, educational material and physical infrastructure. Both "shortage of educational material" and "education staff" were constructed based on school principals' responses to this question. The socio-economic gaps in these indices suggest that some school systems in Southeast Asia could better compensate disadvantaged schools (Figure 11). For instance, Thailand, the Philippines and, to a lesser extent, Indonesia were among education systems in PISA 2018 with the largest gaps between advantaged and disadvantaged schools in both material and human resources. By contrast, in Brunei Darussalam, the socio-economic gap in these resources was just above the average gap among OECD countries. Malaysia, Singapore and Viet Nam exhibited a socio-economic gap only in material resources. 


\section{Figure 11. Difference in shortage of educational material and staff, by schools' socio-economic profile}

Results based on principals' reports

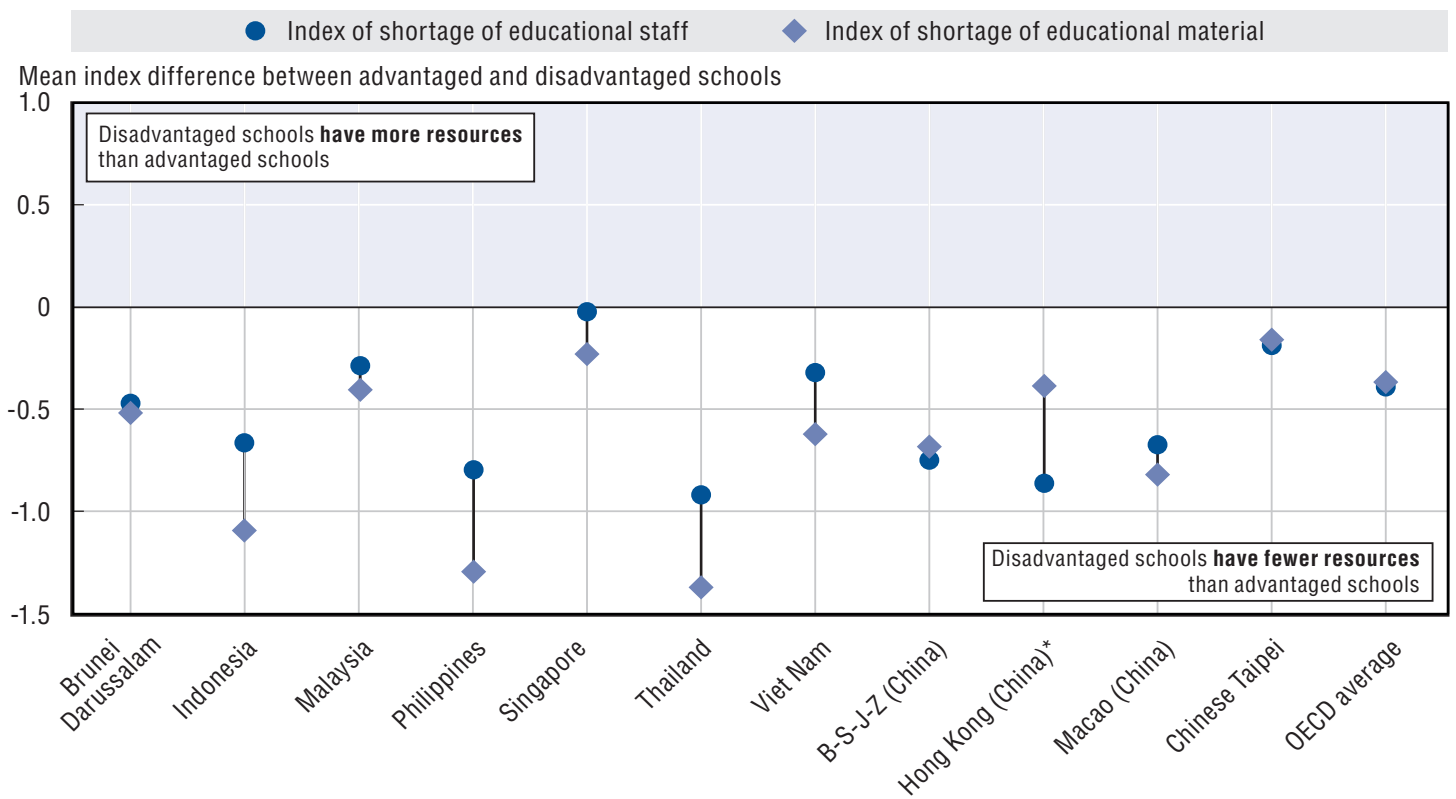

Notes: * PISA 2018 data did not meet the PISA technical standards but were accepted as largely comparable. Statistically significant differences are shown in a darker tone. The socio-economic profile is measured by the school's average PISA index of economic, social and cultural status (ESCS). For this analysis, the sample is restricted to schools with the modal ISCED level for 15-year-old students.

Source: OECD, PISA 2018 Database, Tables II.B1.5.13 and II.B1.5.14.

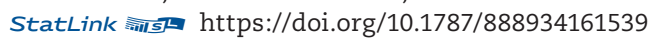

\section{The climate at schools and student well-being}

PISA asked students how often during the 12 months prior to the PISA test they had experienced physical, verbal or relational bullying, such as someone making fun of them, getting pushed around or hit by other students, or being left out on purpose. Combining these statements into a single indicator, "any type of bullying act", shows that students in all Southeast Asian countries were more frequently victimised on average than students across OECD countries or in B-S-J-Z (China). The results for Brunei Darussalam and the Philippines are particularly alarming, with more than half of students saying that they had been bullied at least a few times a month. Almost as troubling were the results in Indonesia and Malaysia, where $41 \%$ and $36 \%$ of students, respectively, reported being bullied at least a few times a month. In comparison, the equivalent shares among OECD countries, B-S-J-Z (China) and Chinese Taipei were $23 \%, 18 \%$ and 13\%, respectively.

The results are more encouraging in the region regarding the disciplinary climate in language-of-instruction lessons, except maybe in the Philippines. The findings on student truancy are also encouraging for Southeast Asia. On average across countries in the region, $19 \%$ of students reported having skipped a whole day of school, compared to $21 \%$ of students on average among OECD countries, but only $1 \%$ of students in B-S-J-Z (China). There are large variations across countries: student truancy was comparatively low in Brunei Darussalam, Malaysia, Singapore and Viet Nam; similar to the OECD average in Indonesia; and comparatively high in Thailand and, to a lesser extent, in the Philippines.

Overall, students in the Southeast Asian countries reported satisfactory levels of wellbeing, though with large variations across the region (Figure 12). On average, about $65 \%$ of 
students in the region reported being satisfied with their lives (7-10 in the life-satisfaction scale), compared to $67 \%$ across OECD countries and $59 \%$ in B-S-J-Z (China). However, in Brunei Darussalam, only $42 \%$ were satisfied with their lives, the lowest percentage across all PISAparticipating countries and economies. About $92 \%$ of students on average across Southeast Asian countries said they were sometimes or always happy - from $85 \%$ in Viet Nam to $95 \%$ in the Philippines - compared to 91\% of students across OECD countries. A larger share of students in the region fear the consequences of failing than on average across OECD countries. This is especially the case in Brunei Darussalam, Malaysia and Singapore. For instance, 73\% of students in Singapore were afraid that failing might signal a lack of talent, compared to $55 \%$ across OECD countries and 53\% in B-S-J-Z (China).

Figure 12. Students' well-being

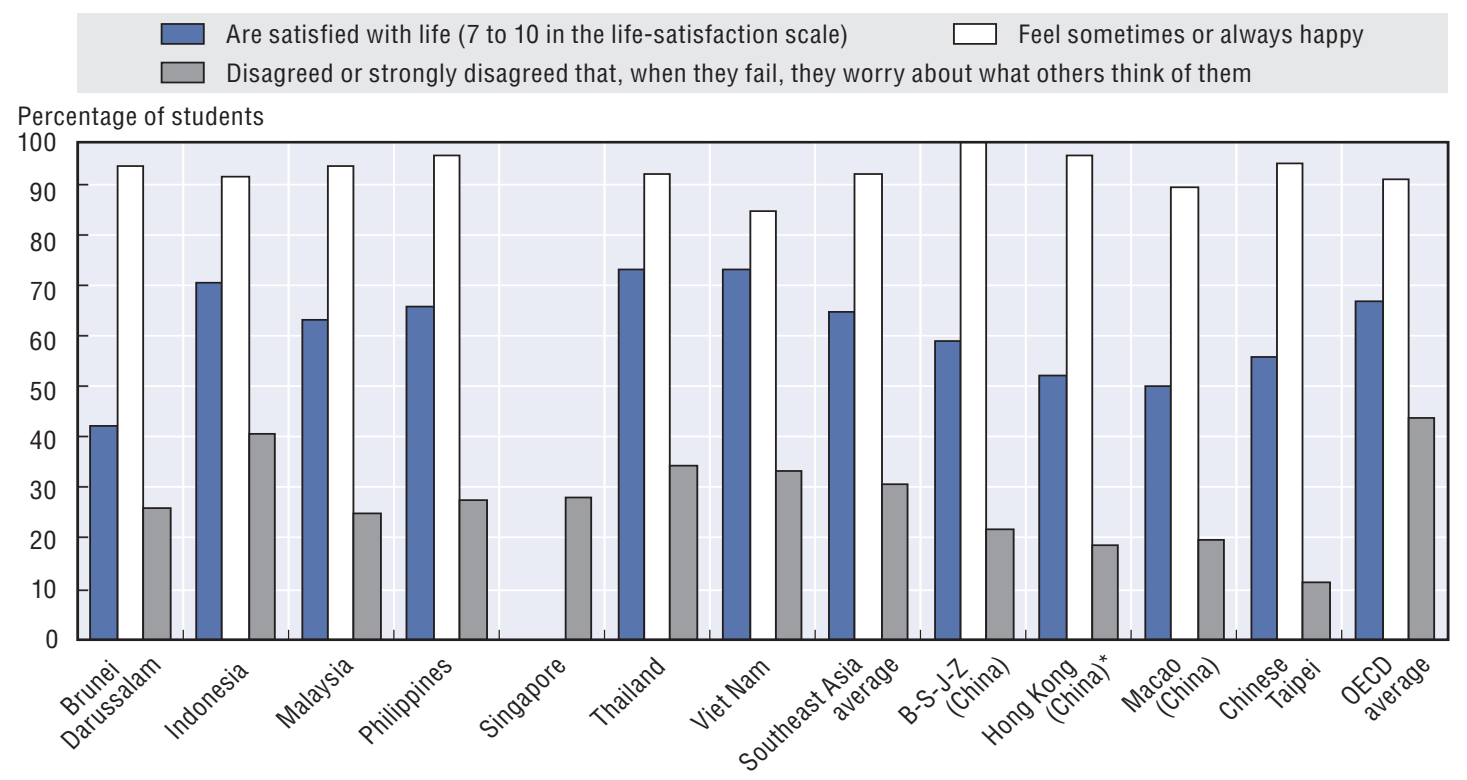

Note: * PISA 2018 data did not meet the PISA technical standards but were accepted as largely comparable. Source: OECD, PISA 2018 Database, Tables III.B1.11.1, III.B1.12.1 and III.B1.13.2.

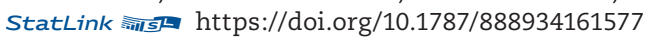

\section{Teaching strategies and policy recommendations}

Compared to students in the OECD, students across Southeast Asian countries reported on average that teachers in their language-of-instruction employed teacherdirected instruction more frequently and provided somewhat more support. By contrast, on average, teachers in the region used adaptive instruction and stimulated reading engagement less frequently than teachers did across OECD countries, at least according to students' reports. All education systems in the region share a comparatively high frequency of teacher-directed instruction and low frequency of adaptive instruction, except for Singapore. In the region, according to students' reports, teacher support was relatively most common in Malaysia; teacher feedback and adaptive instruction were most frequent in Singapore; teacher enthusiasm was most frequently observed in Brunei Darussalam; teacher-directed instruction was most common in Indonesia; and stimulation of reading engagement was most frequent in Thailand.

Providing one-size-fits-all recommendations for such a diverse region as Southeast Asia can be challenging or even counterproductive. For example, as one of the topperformers in PISA since its first participation in 2009, the Singaporean education system 
has been an inspiration for other education systems worldwide, even if its equity outcomes in education could still be improved.

Other than learning from neighbouring countries, general recommendations for Southeast Asian school systems include: i) further improving access to education without sacrificing the quality of the school system; ii) making learning time more productive by building a skilled and dedicated teacher workforce and encouraging teachers to use multiple teaching strategies and types of assessment; iii) addressing gender differences in students' participation in training and studies; iv) creating a positive learning environment; $v$ ) investing greater resources in the school system; and vi) allocating resources more equitably among schools. 


\section{Chapter 1}

\section{Macroeconomic assessment and economic outlook}

This chapter presents the economic outlook for the region in light of the global health crisis and the restrictive measures implemented to combat the disease. It describes the near-term drivers and risks to economic growth, which is projected to decline in 2020 across the 12 economies before rebounding in 2021. It also examines the effects of the crisis on travel and tourism, international trade, private consumption, investment, businesses, employment and financial markets, taking into account the fiscal packages and other policy actions implemented to support the economy. 


\section{Introduction}

The COVID-19 pandemic has brought the global economy to its knees. It has virtually shut down global travel and tourism, and against the backdrop of trade tension it has compounded the pressure on international trade. Restrictions on movement and business uncertainties have weighed on private consumption and investment. As the toll on the job market soars - setting the stage for economic crisis in many parts of the world lockdowns have been lifted even in countries where infection is rising. This impairs the recovery process, especially when health systems are already pushed beyond their limits.

Emerging Asian economies addressed the pandemic using various measures. Policy actions generally included tight quarantine measures coupled with fiscal and monetary support to varying degrees. While the health situation has substantially improved in many economies in the region, India, Indonesia and the Philippines are still struggling to contain transmission of the virus. Given the ongoing elevated health threats, business sectors cannot maximise partial re-opening to recoup their losses and jumpstart job market recovery. The governments' ability to deliver on additional fiscal commitments is also limited by the pandemic's impact on fiscal revenue, given the weaker economic activity.

\section{Figure 1.1. Real GDP growth of Southeast Asia, China and India}

Comparison between 2018, 2019 and 2020 growth rates, percentage

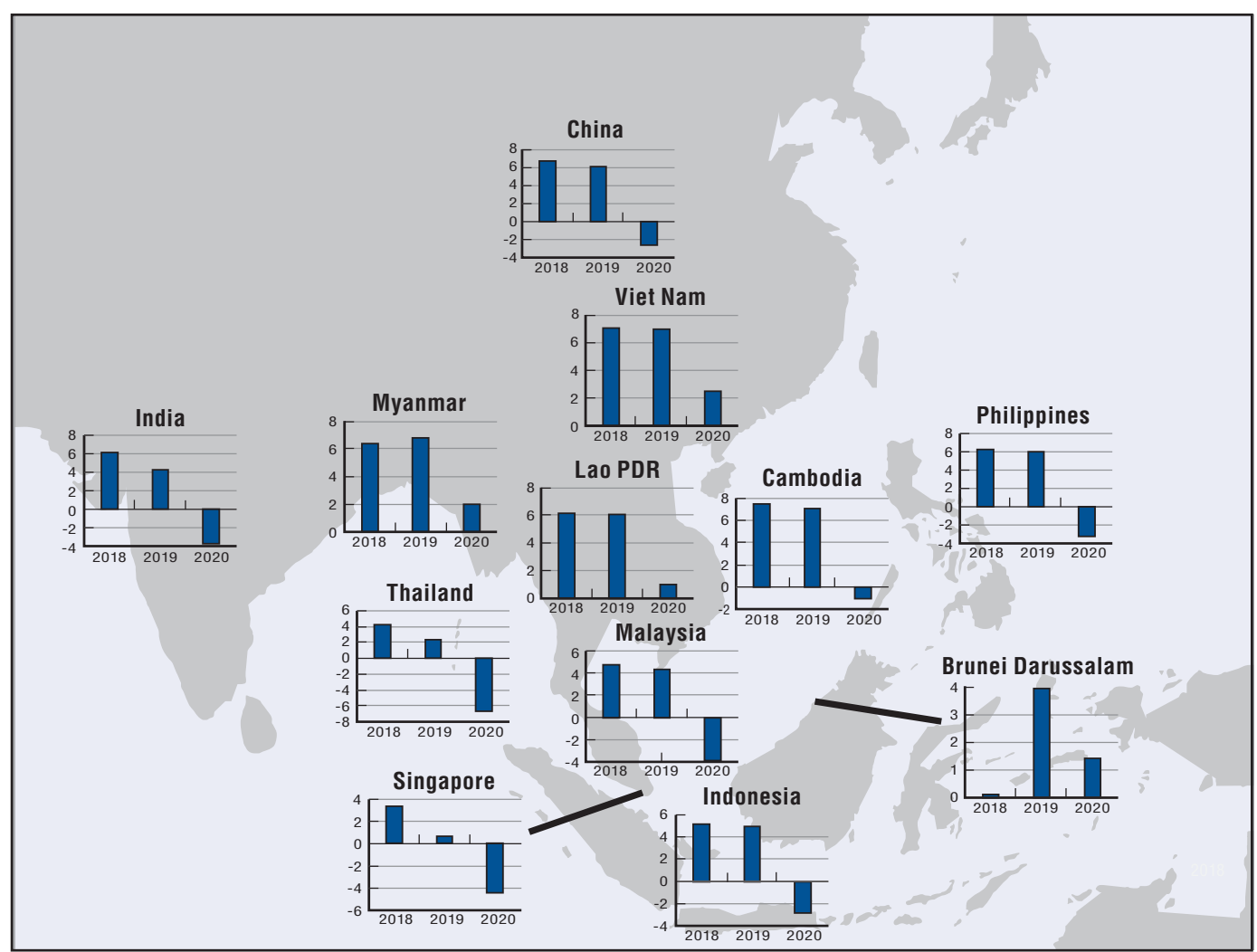

Note: Data are as of 26 June 2020. Data for India and Myanmar relate to fiscal years. For Lao PDR, 2019 GDP growth rate is an estimate. The projections for China, India and Indonesia for 2020 are based on the OECD Economic Outlook 107 (database). The projections assume "single hit" scenarios, in which a second big outbreak is avoided. Source: OECD Development Centre.

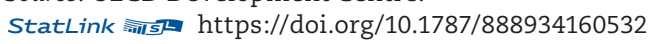

The region's financial markets have absorbed the stress relatively well thus far. Yet the risk of capital flow volatility is broadening, as are risks to banking sector profitability and solvency. Countries with banking stability issues prior to the pandemic, such as India 
and to some extent Lao People's Democratic Republic (hereafter "Lao PDR"), Myanmar and Viet Nam, are arguably more susceptible to shocks. The extent of rising unemployment levels and firm closures in all countries is a big concern in this respect. The condition of macroeconomic fundamentals in the next few months will influence the vulnerability of countries to cross-border capital flow disruption. Massive liquidity injections by the advanced economies into the global financial system are expected to drive rent seeking as interest rates plunge to historic lows in many jurisdictions.

In light of these headwinds, economic performance will weaken significantly across countries in Emerging Asia in 2020 relative to the previous year (Figure 1.1). The decadeslong uninterrupted positive economic growth streaks in many of the region's countries are on track to be snapped at the end of the current year. However, barring an unsettling second wave of COVID-19 infections, growth in gross domestic product (GDP) is expected to recover in 2021.

\section{Overview and main findings}

As COVID-19's grip tightened in the first half of 2020, economies faltered to degrees not experienced in decades. Emerging Asian countries had confirmed more than 1.3 million cases as of early July, roughly $3 \%$ of which had concluded in death. Governments provided massive monetary and fiscal support to lessen the immense stress on health services and keep the social fabric intact. Quarantines and curfews have been imposed to limit the spread of the virus, although these in turn have further hampered economic activity. Progress in containing infections has been uneven across Emerging Asia. The number of cases in India began soaring in June. Indonesia and the Philippines are still confronting a large number of cases daily (Figure 1.2).

Figure 1.2. Cumulative confirmed cases of COVID-19 in Emerging Asia

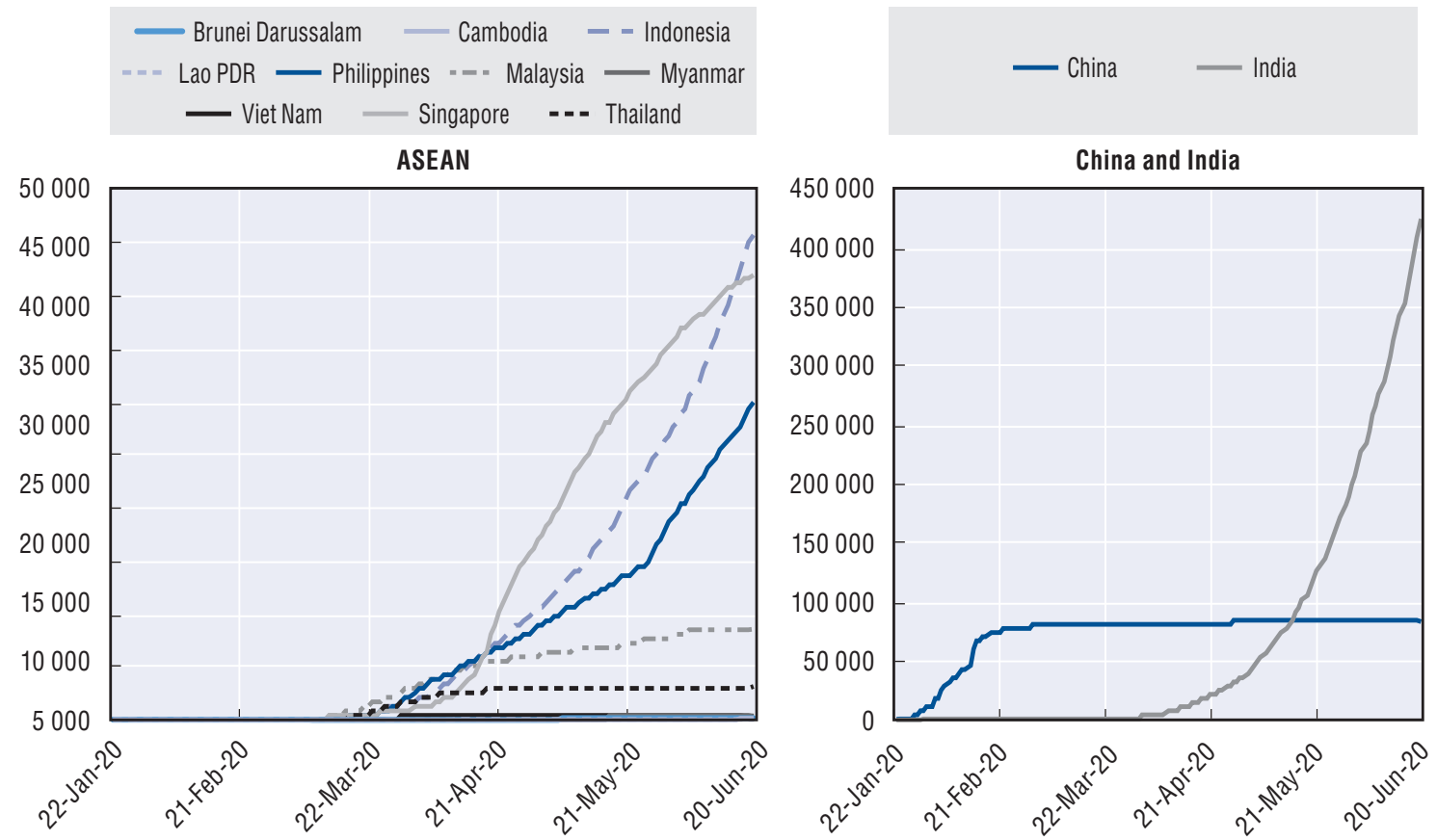

Note: Data as of 21 June 2020.

Source: Johns Hopkins (2020), COVID-19 Map (database), https://coronavirus.jhu.edu/map.html.

StatLink 青政 https://doi.org/10.1787/888934160551 
The growth prospects of Emerging Asian economies have absorbed big blows on several fronts. These economies were already weakening before the outbreak due to the trade tension and structural issues. The most recent national accounts data convey feebleness across demand and supply components in all reporting countries in the region. The health emergency has weighed heavily on aggregate private spending and investment. Production cutbacks have resulted from the curtailing of work hours or total closure of factories and offices.

Although quarantines and restrictions on movement have been relaxed in a number of countries in order to restart economic engines, the path to normalcy is beset by uncertainties and economic recovery is expected to be very gradual. It will likely take a few quarters before the crisis-related restrictions imposed in many countries are lowered to nil. Private consumption expansion will be measured according to the broad and deep impact of the pandemic on labour markets. It is anticipated that spending on basics and the rebuilding of the precautionary savings pool will take precedence among households during the recovery period.

Indications of a healthy trade rebound are limited. The retention of border restrictions, struggling domestic markets in advanced economies, political distrust among major trading countries and a potential re-escalation of the US-China trade tension do not augur well for the cross-border flow of goods. These developments could in turn hamper longterm private investment recovery. Emerging Asian economies generally have room for fiscal manoeuvres, but the space is limited, especially as revenues decline. In certain cases, governments also have to set aside funding for natural disasters that accompany the monsoon season and for other emergencies in the second half of the year.

Against this backdrop, economic output of Emerging Asian countries is projected to contract by $2.9 \%$ in 2020 (Table 1.1). The growth is projected to climb to $6.8 \%$ in 2021 , presupposing that the conditions gradually return to normalcy. Southeast Asia's economy as a whole is expected to contract in 2020 by $2.8 \%$ before growth rises to $5.6 \%$ in 2021 . Economic growth patterns in China and India are anticipated to mirror the same path. China's economy is expected to contract this year for the first time since the 1970 s before GDP growth improves the following year. India's economy will also decline for the first time in more than 40 years and recover in 2021. 
Table 1.1. Real GDP growth in ASEAN, China and India, 2019-21

Percentage

\begin{tabular}{|c|c|c|c|c|c|}
\hline & 2018 & 2019 & 2020 & $\begin{array}{l}\text { Change from the } \\
\text { previous forecast } \\
\text { (Nov. 2019) }\end{array}$ & 2021 \\
\hline \multicolumn{6}{|l|}{ ASEAN- 5 countries } \\
\hline Indonesia & 5.2 & 5.0 & -2.8 & $\downarrow$ & 5.2 \\
\hline Malaysia & 4.8 & 4.3 & -3.9 & $\downarrow$ & 5.9 \\
\hline Philippines & 6.3 & 6.0 & -3.2 & $\downarrow$ & 7.0 \\
\hline Thailand & 4.2 & 2.4 & -6.7 & $\downarrow$ & 4.9 \\
\hline Viet Nam & 7.1 & 7.0 & 2.5 & $\downarrow$ & 7.2 \\
\hline \multicolumn{6}{|c|}{ Brunei Darussalam and Singapore } \\
\hline Brunei Darussalam & 0.1 & 3.9 & 1.4 & $\downarrow$ & 3.3 \\
\hline Singapore & 3.4 & 0.7 & -4.4 & $\downarrow$ & 3.5 \\
\hline \multicolumn{6}{|l|}{ CLM countries } \\
\hline Cambodia & 7.5 & 7.1 & -1.0 & $\downarrow$ & 5.8 \\
\hline Lao PDR & 6.2 & 6.1 & 1.0 & $\downarrow$ & 5.0 \\
\hline Myanmar & 6.4 & 6.8 & 2.0 & $\downarrow$ & 7.3 \\
\hline \multicolumn{6}{|l|}{ China and India } \\
\hline China & 6.7 & 6.1 & -2.6 & $\downarrow$ & 6.8 \\
\hline India & 6.1 & 4.2 & -3.7 & $\downarrow$ & 7.9 \\
\hline Average of ASEAN-10 & 5.3 & 4.7 & -2.8 & $\downarrow$ & 5.6 \\
\hline Average of Emerging Asia & 6.3 & 5.4 & -2.9 & $\downarrow$ & 6.8 \\
\hline
\end{tabular}

Note: Data as of 26 June 2020. Data for India and Myanmar relate to fiscal years. For Lao PDR, 2019 GDP growth rate is an estimate. The projections for China, India and Indonesia for 2020 and 2021 are based on the OECD Economic Outlook 107 (database). The projections assume "single hit" scenarios, in which a second big outbreak is avoided. They also assume that world GDP is declining in 2020 but will almost regain pre-crisis level (2016 level) in 2021.

Source: OECD Development Centre.

\section{ASEAN-5}

- About four months after the first COVID-19 case was confirmed in Indonesia, the country continues to struggle to contain the spread of the virus. As private consumption and investment weaken, GDP in 2020 is forecast to shed about $2.8 \%$ in 2020 in its first contraction since the Asian Financial Crisis.

- Malaysia has managed to rein in COVID-19 cases steadily since April 2020. Nevertheless, private spending resilience is wavering and export prospects remain downbeat. Malaysia experienced marked declines in net exports and investment in Q1 2020. Against this backdrop, GDP is projected to decline by $3.9 \%$ this year.

- Reigniting business remains challenging in the Philippines due to protracted uncertainty over the extent of COVID-19 cases. Flailing export earnings add to the headwinds for growth. The economy is expected to contract by $3.2 \%$ in 2020, its first contraction in more than two decades.

- Thailand has navigated the pandemic relatively well, with daily cases of infection steadily reducing to single digits since peaking in March. However, the grim tourism and trade outlook weigh heavily on the economy. Real GDP level in 2020 is forecast to come in lower than the previous year by about $6.7 \%$.

- Viet Nam is on track for an exceptional record in public-health crisis management despite the many limitations that the country faces. The considerable dissipation of the health risk has made the environment conducive to a smoother recovery for many firms. GDP growth will slow in 2020 to $2.5 \%$, but the country will continue to lead the ASEAN-5 on this metric. 


\section{Brunei Darussalam and Singapore}

- The comparatively effective COVID-19 management system in Brunei Darussalam allowed the economy to remain partially open even as other ASEAN economies went into strict lockdown. The gradual reversal of the sharp drop in oil prices bodes well for the economy in terms of export earnings and fiscal space. However, with uncertainties in external markets and constraints to fiscal capacity, GDP growth is forecast to roll back to $1.4 \%$ in 2020 .

- A second wave of infections has pushed back Singapore's re-opening plans. Robust monitoring and healthcare systems proved to be crucial in keeping social order. Government interventions were similarly helpful in limiting firm closures. Nonetheless, the prevailing weakness in domestic and external demand continues to strain economic prospects. GDP is projected to contract by $4.4 \%$ in 2020 .

\section{Cambodia, Lao PDR and Myanmar}

- Cambodia is weathering the COVID-19 health risks comparatively well, helping to maintain a buoyant domestic economy despite the restrictions. However, growing risks to exports and friction on investment are set to drag down gross economic production by $1.0 \%$ in 2020 , notwithstanding government assistance programmes. Economic activity is forecast to improve the following year when external uncertainties wane.

- Lao PDR has dealt with the threat of COVID-19 rather well, containing incidents of local transmission of the virus. Keeping risks to domestic labour-market stability at bay augurs well for private consumption. A challenge will be finding markets for the country's electricity exports given the slowdown in industrial activity in the region. The country's GDP is expected to register growth of $1.0 \%$ in 2020.

- The health situation in Myanmar has improved in recent weeks, although security issues in certain areas complicate the response to the health crisis. Easing stress on the growing tourism industry and coping with the wavering export and investment climate are crucial for the economy's stability. Given current conditions, GDP growth is projected to slow to $2.0 \%$ in 2020 .

\section{China and India}

- Notwithstanding new pockets of infection in certain areas, China is on its way to restoring its full economic capacity. Strong growth in technology-based emerging sectors has helped lessen the economic impact of the lockdown and is paving the way for a full rebound in domestic activity. Overall, however, the domestic sector is still groping for balance. With trade tension still dominating bilateral relations, local production is unlikely to draw as much drive from the external market. GDP is projected to decline by about $2.6 \%$ at the end of 2020 in the economy's first contraction since the 1970s.

- India has become the new epicentre of COVID-19 in Asia, and the government is grappling to reverse the persistent rise in active cases. Fiscal limitations and banking-sector legacy asset issues compound difficulties in managing the economic risks. Deeply entrenched informal activity in the country is another complication given restrictions on the movement of labourers. Against this backdrop, the economy is forecast to end fiscal year (FY) 2020 (ending in March 2021) in the red. The contraction of about $3.7 \%$ will snap the country's four-decade streak of positive growth. 


\section{Other key points of the economic outlook and assessment}

- The extent of monetary support in major economies effectively ushers in a return to the low-interest rate, high-liquidity environment experienced during quantitative easing. To support the ailing domestic credit market, Emerging Asian economies have ramped up monetary accommodation in a continuation of the policy mix of the previous year.

- Governments in Emerging Asia have taken drastic measures to finance pandemicrelated spending. The fiscal outlays of ASEAN countries for health services, tax adjustments, subsidies and income support (excluding credit guarantees, money market intervention, direct lending and those with no breakdown) range from less than $0.1 \%$ to approximately $9 \%$ of GDP. In terms of debt, Emerging Asian economies had some fiscal leeway heading into this year, with measured government debt management in the last few years. Nonetheless, the sheer spending requirements needed to maintain social order and help the real economy regain its pre-pandemic health will test fiscal capacity.

- The collapse in economic activity led to both demand- and supply-side pressures in Emerging Asian countries. The aggregate effect of the COVID-19 crisis on inflation is therefore rather difficult to gauge and will depend on how these two forces balance out. Headline inflation in the region has moderated overall. At the same time, low global oil prices, which weighed on overall inflation in the first few months of the year, are on an upward trend. The aggregate figures may nevertheless hide differences at the sectoral levels.

- The flood of liquidity into global financial markets could have repercussions on the volatility of cross-border hot capital flows over the course of a few quarters. The ability to keep macroeconomic fundamentals sound during the recovery process will be essential for smoothing cross-border capital movement. Emerging Asian currencies have mostly weakened vis-à-vis the US dollar, reversing the 2019 trend.

- Corporate earnings are under heavy fire as the real sector reels from the impact of COVID-19. Grim expectations on corporate performance pushed bellwether indices to multi-year lows in the first four months of 2020. Yet hopes brought by the partial re-opening of economies have led equity prices higher since they bottomed in the March-April period.

- The current account balances of the region's economies are expected to weaken in the coming quarters. Tight border restrictions for shipments will continue to dampen cross-border trade. The risk of a revived trade tension could complicate the environment. Separately, remittances from foreign workers are expected to weaken significantly in the next few quarters, with many layoffs unlikely to be reversed in the short term.

\section{Recent developments and near-term outlook}

The rapid spread of COVID-19 is putting immense pressure on economic and social conditions in Emerging Asia. While COVID-19 has caused a lower death toll than the 1957 influenza pandemic or H1N1 in 2009-10 (as of early July), its coverage in terms of the number of countries affected and the potential economic cost will be much more significant (Box 1.1). 


\section{Box 1.1. Comparison of past pandemics}

Epidemic and pandemic diseases have posed threats to human flourishing throughout history. The world remains under-prepared to contain epidemic and pandemic diseases, which are increasingly difficult to manage. A review of recent pandemics, associated responses and outcomes is given below (Table 1.2).

\section{Influenza Pandemic}

The 1957 influenza pandemic ("Asian flu") was a category 2 outbreak of avian influenza that emerged in early 1956 and lasted until 1958. A vaccine for H2N2 was introduced in 1957 , and the pandemic slowed. There was a second wave in 1958, and H2N2 went on to become part of the regular wave of seasonal flu.

\section{Influenza Pandemic}

The 1968 influenza pandemic ("Hong Kong flu") was a category 2 flu pandemic that killed an estimated 1 million people worldwide in 1968 and 1969. It was caused by an H3N2 strain that descended from H2N2 through antigenic shift - a process in which genes from multiple subtypes reassort to form a new virus. The disease yielded a low death rate compared to other pandemics, with a case fatality rate below $0.5 \%$.

\section{SARS}

SARS-CoV ("severe acute respiratory syndrome coronavirus") emerged in 2002. The sequence of the virus was significantly different from other coronaviruses known to cause human disease at the time. Public health measures to try to control the disease included earlier detection, isolation of infected people, droplet and contact precautions, and the use of personal protective equipment (PPE), including masks and isolation gowns. A screening process was put in place at airports to monitor air travel to and from the affected countries.

\section{H1N1 Swine Flu}

The H1N1 swine flu pandemic broke out in 2009. The virus, first described in April that year, appeared to be a new strain of the H1N1 influenza virus that arose when a previous triple reassortment of bird, swine and human flu viruses further combined with a Eurasian pig flu virus. The World Health Organization (WHO) raised the worldwide pandemic alert level to Phase 6, signalling that a global H1N1 pandemic was underway in July 2009. At the time, more than 70 countries had reported cases of 2009 H1N1 infection, and community-level outbreaks of 2009 H1N1 were ongoing in multiple parts of the world.

Table 1.2. Comparative global toll of epidemics since the 1950 s

\begin{tabular}{lccccc}
\hline \multicolumn{1}{c}{ Epidemic } & Period & Cases & Deaths & Case fatality rate & Major intervention \\
\hline $\begin{array}{l}1957 \text { influenza } \\
\text { pandemic }\end{array}$ & $1957-58$ & ---- & 1.1 million & $0.04-0.07 \%$ & Vaccine \\
$\begin{array}{l}1968 \text { influenza } \\
\text { pandemic }\end{array}$ & $1968-69$ & ---- & 1 million & $0.03-0.12 \%$ & Vaccine \\
SARS & $2002-03$ & 8096 & 774 & $9.6 \%$ & $\begin{array}{c}\text { Quarantine and } \\
\text { medical treatment }\end{array}$ \\
H1N1 Swine Flu & $2009-10$ & --- & $0.1-0.6$ million & $-\cdots$ & Vaccine \\
\hline
\end{tabular}

Note: Death figures are estimates except for SARS.

Source: OECD Development Centre based on various government sources. 
In the current pandemic, most Emerging Asian countries imposed lockdown measures as early as January in China and in March elsewhere to slow the spread of the virus (Table 1.3). The measures, of varying duration, geographical coverage and scope, have been partially lifted in many countries but could be reinstated if new waves of COVID-19 occur.

Lockdown measures help to contain the spread of the virus, but they also prevent economic activity that would otherwise take place. As the debate in countries turns to how and when to end a lockdown and restart the economy, the health and economic implications of the lockdown measures need to be considered carefully.

Table 1.3. Overview of COVID-19 lockdown measures in Emerging Asian countries

\begin{tabular}{|c|c|c|}
\hline Country & Date of first announcement & Geographical coverage \\
\hline China & $\begin{array}{l}23 \text { January } 2020 \text { (Wuhan), } 23 \text { and } 24 \text { January in other } \\
\text { cities in Hubei Province, then some other cities }\end{array}$ & $\begin{array}{l}\text { Wuhan in Hubei province was first to be placed under } \\
\text { lockdown and other cities and districts in China followed } \\
\text { suit }\end{array}$ \\
\hline India & 24 March 2020 & Nationwide \\
\hline Indonesia & 16 March 2020 & $\begin{array}{l}\text { Closure of public places in several provinces, large-scale } \\
\text { social restrictions in Jakarta }\end{array}$ \\
\hline Lao PDR & 29 March 2020 & Nationwide \\
\hline Malaysia & 16 March 2020 & Nationwide \\
\hline Myanmar & 3 April 2020 & Region of Mandalay \\
\hline Philippines & 16 March 2020 & $\begin{array}{l}\text { Metro Manila, Luzon and selected provinces, cities and } \\
\text { localities in Visayas and Mindanao regions }\end{array}$ \\
\hline Singapore & 6 April 2020 & Nationwide \\
\hline Thailand & $\begin{array}{l}22 \text { March } 2020 \text { (Bangkok), followed by some other } \\
\text { provinces and cities }\end{array}$ & $\begin{array}{l}\text { Bangkok and several provinces, including Phuket, island } \\
\text { of Koh Samui and Pattaya City }\end{array}$ \\
\hline Viet Nam & 31 March 2020 & $\begin{array}{l}\text { Nationwide, with social distancing measures in some } \\
\text { provinces }\end{array}$ \\
\hline
\end{tabular}

Source: OECD Development Centre based on various national sources.

\section{ASEAN-5}

Indonesia

Indonesia, the most populous country in Southeast Asia, is still struggling to contain the spread of COVID-19 four months after the first case was confirmed in the country in early March. The cases have risen sharply. The case fatality rate in the country is the highest in Southeast Asia, at approximately 5.4\%. The government declared a state of emergency that resulted in the closure of most businesses near the end of March. This was followed by the imposition of quarantine and curfew measures in wider Jakarta and other regions. ${ }^{1}$ In an effort to limit economic losses, businesses were allowed to re-open in June, with schools expected to follow. The capital, with about $4 \%$ of Indonesia's population and $17 \%$ of the national GDP, accounts for more than $20 \%$ of the country's confirmed cases.

Real GDP level in 2020 is forecast to decrease by $2.8 \%$, marking the country's first economic contraction since the Asian Financial Crisis two decades ago. Economic growth is set to rebound in 2021, assuming the health crisis wanes substantially. In Q1 2020, the economy managed to expand by $3.0 \%$ (Table 1.4). Private consumption growth ebbed, though it still provided the biggest contribution to economic expansion (Figure 1.3). While government consumption accounts for a smaller share in GDP, it picked up from the previous quarter to lend support. Exports were lethargic, and this was matched by a contraction in imports for the fifth straight quarter. Investment growth also slid to close to its slowest rate since Q4 2015. On the supply side, all main sectors showed slower growth than in the previous quarter. However, the financial services subsector grew markedly, aided by technology. 
Table 1.4. Recent real GDP growth in ASEAN, China and India, 2018-19 Quarterly year-on-year percentage

\begin{tabular}{|c|c|c|c|c|c|}
\hline & Q1 2019 & Q2 2019 & Q3 2019 & Q42019 & Q12020 \\
\hline \multicolumn{6}{|l|}{ ASEAN-5 countries } \\
\hline Indonesia & 5.1 & 5.1 & 5.0 & 5.0 & 3.0 \\
\hline Malaysia & 4.5 & 4.8 & 4.4 & 3.6 & 0.7 \\
\hline Philippines & 5.7 & 5.4 & 6.3 & 6.7 & -0.2 \\
\hline Thailand & 2.9 & 2.4 & 2.6 & 1.5 & -1.8 \\
\hline Viet Nam & 6.8 & 6.7 & 7.5 & 7.0 & 3.8 \\
\hline \multicolumn{6}{|c|}{ Brunei Darussalam and Singapore } \\
\hline Brunei Darussalam & -0.2 & 6.6 & 2.1 & 7.1 & - \\
\hline Singapore & 1.0 & 0.2 & 0.7 & 1.0 & -0.7 \\
\hline \multicolumn{6}{|l|}{ CLM countries } \\
\hline Myanmar & 6.6 & 5.7 & 7.5 & 7.9 & - \\
\hline \multicolumn{6}{|l|}{ China and India } \\
\hline China & 6.4 & 6.2 & 6.0 & 6.0 & -6.8 \\
\hline India & 5.2 & 4.4 & 4.1 & 3.1 & - \\
\hline
\end{tabular}

Note: Data as of 26 June 2020. Data for India and Myanmar relate to fiscal years.

Source: OECD Development Centre based on CEIC and national sources.

Figure 1.3. Contribution to growth by components in ASEAN-5, 2018-20

Percentage points

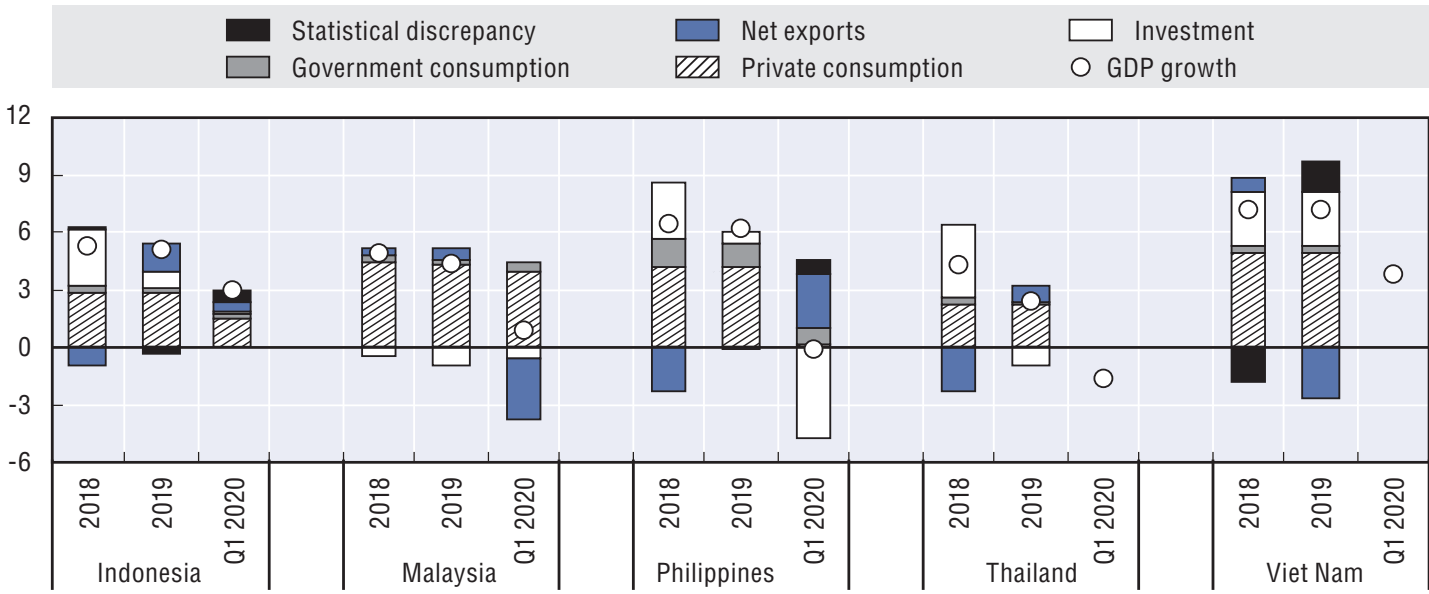

$\square$ Net Taxes $\square$ Services $\square$ Industry $\quad \square \mathbb{M} A$ Agriculture $\quad$ GDP growth

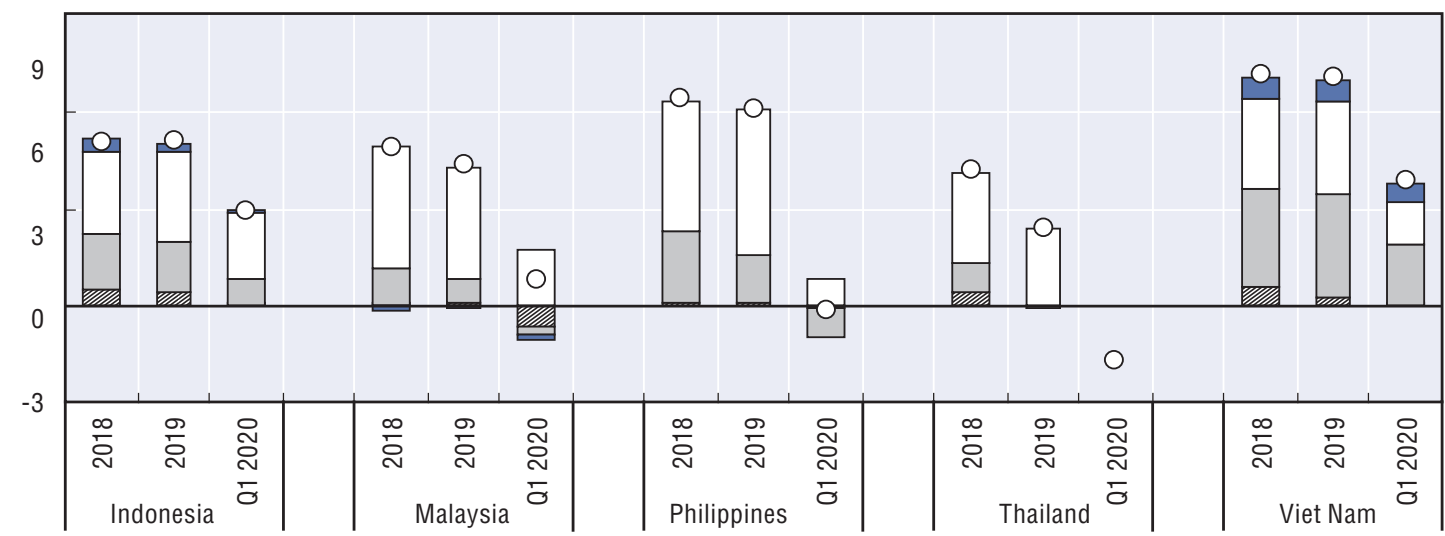

Note: The agriculture sector refers to agriculture, fisheries and forestry in the data compilation. Net taxes are equal to gross tax minus subsidies. Thailand uses chain volume measures, and the sum of contributions to growth is not necessarily equal to GDP growth. Viet Nam has not yet published the demand-side components of GDP. The data are as of 26 June 2020.

Source: OECD Development Centre based on CEIC and national sources.

StatLink 形Ist https://doi.org/10.1787/888934160570 
Near-term prospects in Indonesia are uneasy as consumption pulls back and exports reel from weakening external demand. The retail sales index went into deeper contraction in April and May. Motor vehicle sales collapsed in the same period, falling by over $90 \%$ year-on-year in both months, with the confidence index suggesting deep caution among consumers. Increased pessimism among enterprises and continued slippage in foreign tourist arrivals signal a potentially slow recovery in many sectors. With the expected rise in unemployment, the poverty rate is projected to rise by about a percentage point this year, depending on the impact of government interventions (Bappenas, 2020a; 2020b). Sluggish nominal goods exports, coupled with the sharp fall in global oil prices from last year (before the recovery since end-April), add to the heavy economic drag. The government is trusting in the National Economic Recovery programme rolled out in May 2020 for economic guidance and support for enterprises, including those that are state-owned (Ministry of State Secretariat-Indonesia, 2020). The 3\% deficit ratio threshold had been suspended by the government this year to gain spending flexibility. Thus far, national government support amounts to roughly 3.5\% of GDP, according to the Asian Development Bank (ADB, 2020). ${ }^{2}$ Measures to ease pressure in the money market and loan guarantees further amount to about $2.4 \%$ of GDP (ADB, 2020). These interventions accompanied the policy and bank reserve requirement rate cuts announced by the central bank.

\section{Malaysia}

Malaysia has steadily reined in COVID-19 cases since April 2020. The country registered its first case in late January, barely two weeks after the first case in Southeast Asia was confirmed in Thailand. The number of confirmed cases started to pick up pace in the second week of March. A national Movement Control Order (lockdown) was announced the following week, and stricter measures were imposed in certain areas as the situation evolved. As of early July, Malaysia had more than 8500 confirmed cases, of which roughly $1.4 \%$ had resulted in death. Confirmed cases are concentrated in the Kuala Lumpur and Selangor areas, which account for about $40 \%$ of national GDP (Box 1.2). The economy is being reopened gradually, but foreign travel restrictions are set to remain until August. While battling COVID-19, the country is also in the process of regaining political stability. Almost two years after the national elections, a new prime minister was sworn in on 1 March.

\section{Box 1.2. Economic centres bear the brunt of COVID-19 in Emerging Asia}

Statistics on the progression of COVID-19 in Emerging Asian economies are not necessarily comparable due to the differing extent of testing and tracing conducted. They may also differ in terms of data gathering and counting methodologies. Nevertheless, the reported data reveal some valuable insights.

Overall, China and India have reported the highest incidence of the disease (Figure 1.4). Infection rates in the region appear to be higher in agglomerations where population density is also high. China, Indonesia and the Philippines lead the region in terms of case fatality rate (deaths as a proportion of reported cases). This may reflect the readiness and capability of health systems to handle the influx of COVID-19 patients. Beyond hospital capacity, early detection seems to be a crucial factor. 
Box 1.2. Economic centres bear the brunt of COVID-19 in Emerging Asia (cont.) Figure 1.4. COVID-19 confirmed cases and case fatality rates in Emerging Asia

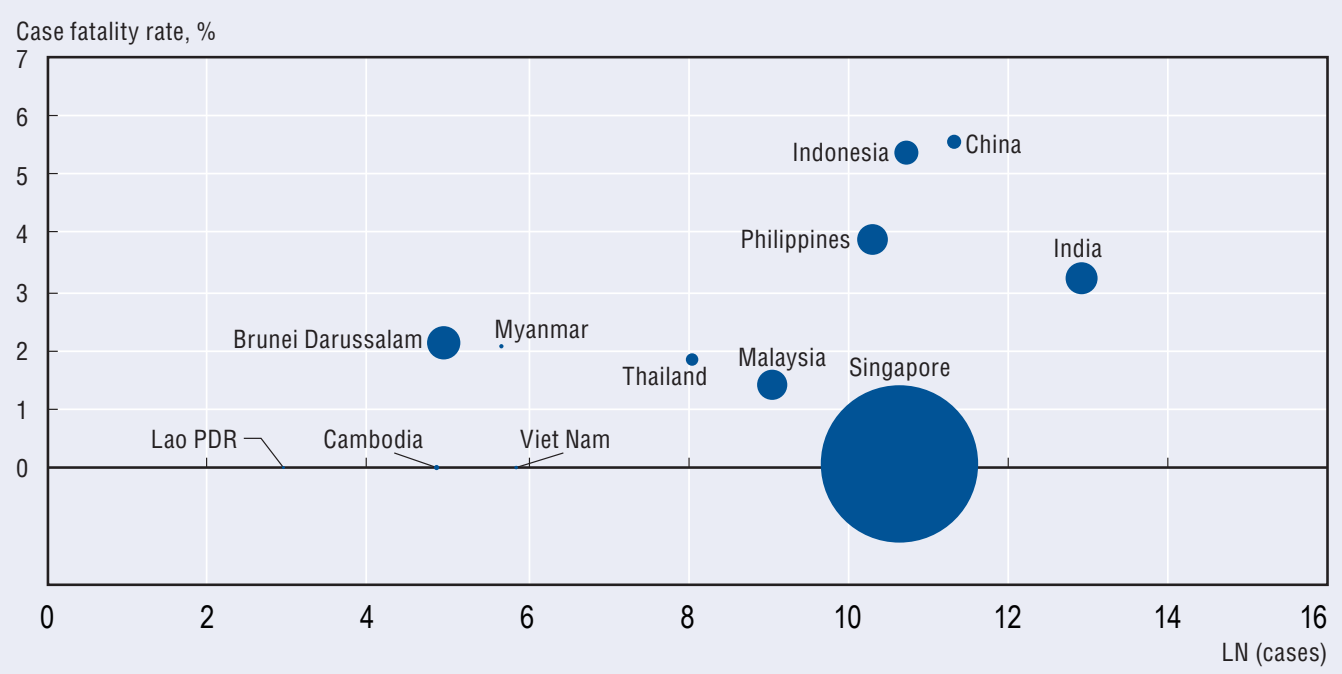

Note: The bubble size represents the number of reported cases as a proportion of the population. LN (cases) means natural logarithm of total reported confirmed cases. Data are as of 21 June 2020.

Source: OECD Development Centre based on national sources; Johns Hopkins (2020), World Map (database), https://coronavirus.jhu.edu/map.html; UN, Department of Economic and Social Affairs, Population Division (2018).

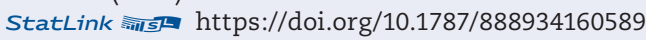

Viet Nam and the CLM economies (Cambodia, Lao PDR, Myanmar) have weathered the pandemic crisis comparably well. Considering Viet Nam's economic size, population and links with the global economy, its performance is particularly notable. Early measures, including border closures, quarantines, travel restrictions, targeted testing and monitoring protocols at the neighbourhood-level, kept the rate of infection low and averted a build-up of pressure on its limited healthcare system (Flemming, 2020; CSIS, 2020).

Country-level data in ASEAN-5 show that cases are disproportionately more prevalent in major cities and urban areas, making it more difficult to deal effectively with the health and economic effects of the pandemic. This is particularly glaring in the Philippines, where Metro Manila (the National Capital Region) and Central Visayas account for nearly $70 \%$ of total officially confirmed cases. Bangkok accounts for about $50 \%$ of the confirmed cases in Thailand. The pattern throughout the region may be linked to the location of major airports and to population density (taking into account the cluster of informal communities). The sheer size of urban agglomerations in terms of inhabitants and geographic area created a major challenge for health systems before restrictions were imposed. Moreover, a large proportion of economic activity occurs in these areas. The top two local agglomerations where COVID-19 is most widespread account for roughly $31 \%$ of national GDP in Indonesia, 40\% in Malaysia, 50\% in the Philippines, 34\% in Thailand and $39 \%$ in Viet Nam (Figure 1.5). Reducing activity to bare essentials in these agglomerations has entailed substantial socio-economic costs. 
Box 1.2. Economic centres bear the brunt of COVID-19 in Emerging Asia (cont.)

Figure 1.5. Most affected areas in ASEAN-5, share in COVID-19 cases and national GDP

Percentage

COVID-19 cases share (LHS) $\quad \diamond$ GDP share (RHS)

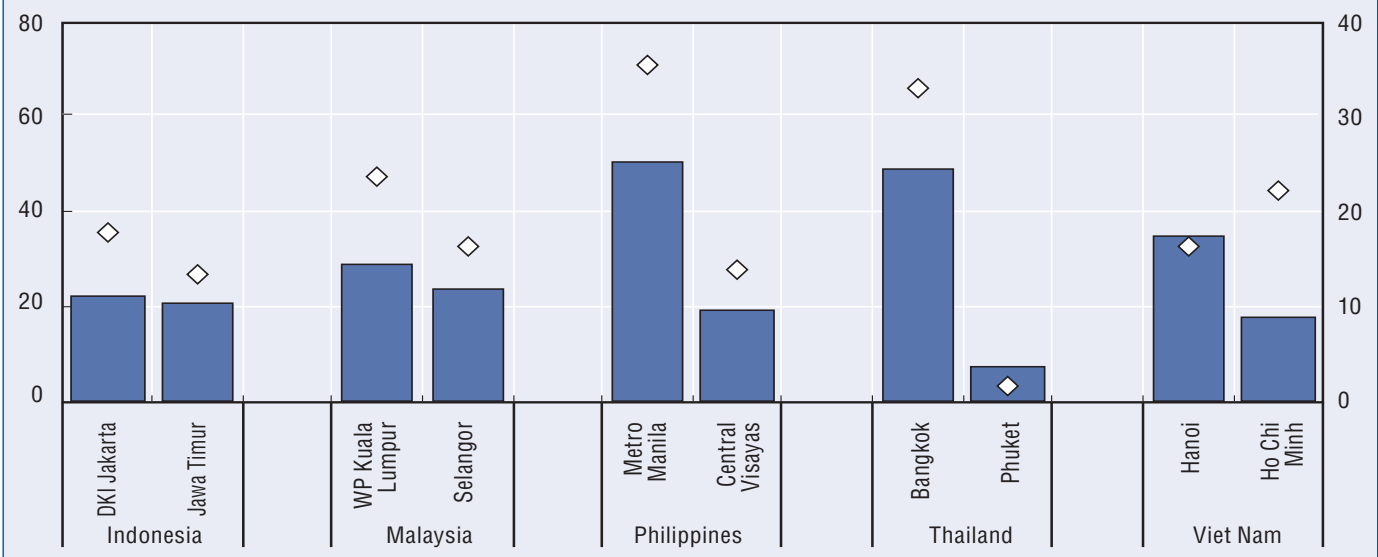

Note: Agglomerations are based on the definitions of national authorities as published. They may or may not be strictly comparable across countries. Only the top two areas in terms of share are included in the chart. COVID-19 data are as of 21 June 2020. GDP shares are based on current price series except for Malaysia (constant price) and refer to 2019 for Indonesia and 2018 for the rest. LHS means left-hand scale. RHS means right-hand scale.

Source: OECD Development Centre based on national sources and CEIC.

StatLink ails https://doi.org/10.1787/888934160608

The Malaysian economy is projected to contract by 3.9\% in 2020. The GDP growth rate in Q1 2020 slipped to $0.7 \%$, almost 3 percentage points lower than the previous quarter and the lowest rate since Q3 2009. Household and government spending helped to spur aggregate demand, but investment and exports slid substantially. On the supply side, the agriculture and industry sectors contracted while growth in the services sector was halved from Q4 2019. The economy is set to gain some lift in 2021 on robust fundamentals.

Household consumption indicators suggest a continued pullback in spending as the COVID-19 threat evolves, and consumer pessimism appears to be building. Retail sales and motor vehicle sales plunged markedly in April. Palm oil output grew little in April and May, while the manufacturing purchasing managers index plummeted by more than 17 index points before posting a healthy rebound (IHS Markit, 2020). With export prospects becoming even more downbeat and business sentiment flailing, much depends on the efficacy of stimulus packages announced between February and June and accompanying enterprise support interventions. The packages from the national government are estimated to be roughly $4.8 \%$ of GDP (ADB, 2020). The packages include health spending; temporary tax and social security relief; cash transfers to affected sectors; infrastructure spending; wage and personnel training subsidies; and grants to small businesses. Additionally, support for the money market and credit creation, including direct lending, amounts to more than $11 \%$ of GDP. The central bank has also lowered the policy rate by 100 basis points (bps) since the start of the year.

\section{Philippines}

With limited testing capacity five months into the pandemic despite sizeable public fundraising, the Philippines is experiencing protracted uncertainty over the extent of COVID-19. The country's first case was confirmed in late January, and the daily tally 
started to climb steeply around the second week of March. The government imposed a lockdown on the island of Luzon, which includes Metro Manila, and then announced a national state of calamity. Local governments in a number of provinces and cities outside Luzon implemented localised lockdowns, effectively restricting movement in the entire country. The Philippines has one of the highest number of COVID-19 cases in Southeast Asia as of early July. The case fatality rate, at about 3.9\%, is just slightly below Indonesia's. Confirmed cases are very much concentrated in Metro Manila and Central Visayas, which jointly produce roughly half of the national GDP. The Enhanced Community Quarantine was partially relaxed in mid-May in some areas, but the ground measures remain tight, particularly in the capital.

The economy is expected to contract by $3.2 \%$ in 2020 , the first red mark since the Asian Financial Crisis and the deepest drop in over 30 years. Modest growth is projected the following year when normalcy is restored and election spending picks up ahead of the 2022 national polls. The economy already shed $0.2 \%$ in Q1 2020. Private spending barely grew, as public spending rose briskly. Investment shrank by more than $18 \%$. Fixed investment slipped considerably, while stocks registered substantial withdrawals. Gross exports retreated, matched by an even deeper drop in gross imports. Agriculture and industry output was pared on the supply side. The services sector grew at a measly rate, largely driven by finance and information and communication services.

The considerable drag on business operations and infrastructure projects across the archipelago will mute economic performance in the second and probably third quarters. The net sales index dropped steeply in April, while vehicle sales almost flatlined in April and May. With consumer confidence down, the consumer outlook in the next quarter and year has worsened (Bangko Sentral ng Pilipinas, 2020a). Growing employment pressure faced by overseas workers - both land-based and sea-based - could erode remittance inflows and further restrain household spending. Repatriations will also challenge the ailing domestic labour market (Box 1.3). Export earnings plummeted by more than half in April to compound the difficulties. The government's projected increase in the fiscal deficit ratio of over 5 percentage points from 2019 could help facilitate a smoother restart of the economy. National government outlays, covering cash transfers to low-income households, social protection for vulnerable workers, medical response spending and other items, are estimated to reach about $2.7 \%$ of GDP (ADB, 2020). Leaving fiscal space for the upcoming monsoon season will be crucial to keep the crisis response system well-functioning and mitigate further socio-economic costs. On the monetary front, the central bank continued to cut its policy rate guidance and the bank reserve requirement ratio, as in the previous year. Additional measures amounting to about $1.7 \%$ of GDP were rolled out to keep the credit flow from tightening (ADB, 2020).

\section{Box 1.3. Labour market vulnerabilities in Emerging Asia}

Policy makers in Emerging Asia understand that containing the labour-market impact of the pandemic is crucial for smoothing the path to economic recovery. This is important for stimulating private spending, the main driver of domestic demand in many Emerging Asian economies. It is key to ensuring that personal and business loans do not turn sour in order to hold financial risks at bay. It is also vital for sustaining the gains made in reducing poverty and advancing social welfare. The task, however, will require considerable effort and ingenuity in policy making. 


\section{Box 1.3. Labour market vulnerabilities in Emerging Asia (cont.)}

Heading into the crisis, labour markets in the region were generally in stable condition regarding unemployment, but they are likely to experience deep and protracted adjustments moving forward. Indeed, sharp spikes in unemployment rates in countries with official unemployment data after Q1 2020 are worrisome. The unemployment rate in Malaysia rose to 5\% in April 2020 from 3.4\% a year earlier. In the Philippines, the joblessness rate climbed to 17.7\% in April 2020 from 5.1\% in April 2019 despite a drop in the labour participation rate of almost 6 percentage points during the same period.

A portion of jobs lost during the crisis, especially in the hospitality industry, cannot be replaced quickly. The aviation sector is anticipated to experience a particularly slow recovery (Pearce, 2020). Even if the 11.2 million jobs expected to be lost in Asia (IATA, 2020) are eventually restored, this will take time. The accelerated adoption of digital solutions during the crisis makes restoring lost jobs even more challenging.

Underemployment, labour informality and lack of well-established unemployment protection are the other sources of labour market vulnerabilities in Emerging Asia. Underemployment in Brunei Darussalam, Lao PDR and the Philippines is estimated to exceed $10 \%$ of the labour force in 2019 (Figure 1.6). Labour informality in the non-agriculture sector comprises more than half of the total number of workers in many countries in the region (Figure 1.6).

"No work, no pay" situations in low-paying jobs place many of these workers at the mercy of emergency government subsistence allowances. Furthermore, for these types of jobs - sidewalk or street vendors, small unregistered business owners and workers, informal transport providers, etc. - resumption of work depends on more than just loosening of restrictions, making reintegration into the labour market difficult for informal workers.

Figure 1.6. Unemployment, underemployment and labour informality in Emerging Asia

- Emerging Asia $\quad \square$ OECD
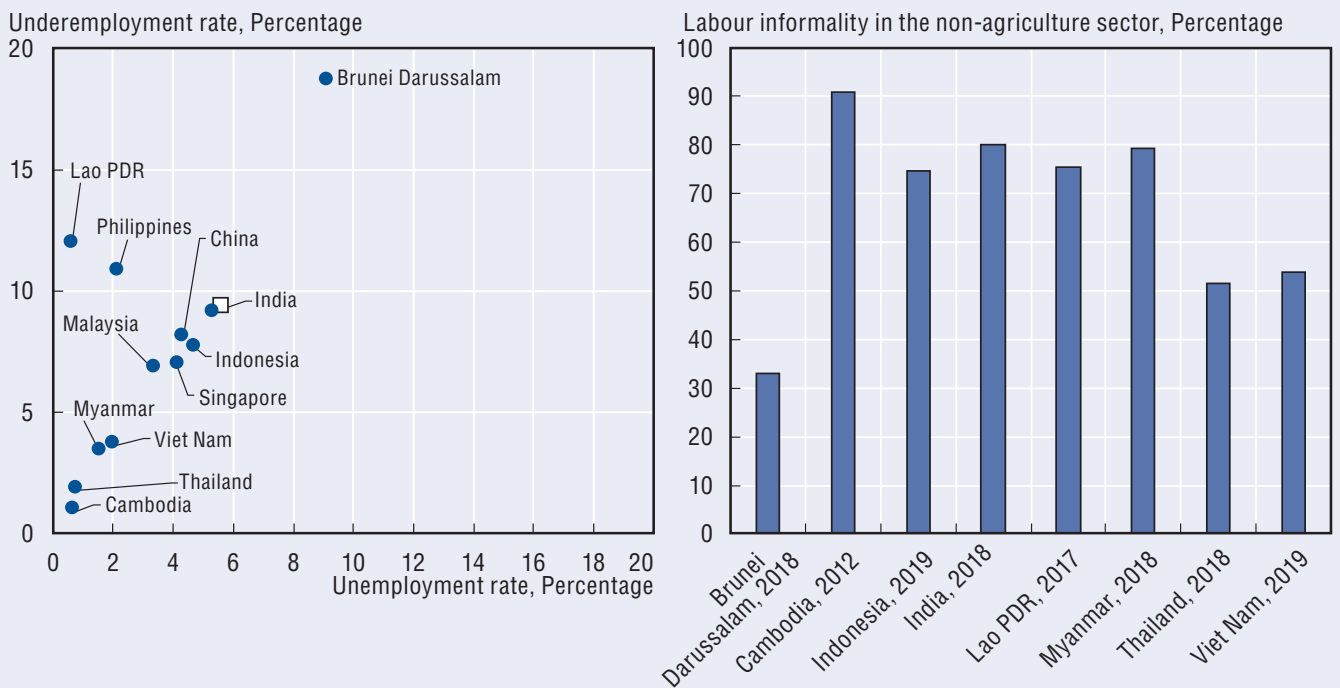

Note: The unemployment and time-related underemployment data refer to the ILO modelled estimates in November 2019. The OECD data refer to the simple average of the 36 OECD member countries using ILO data. Labour informality refers to the proportion of informal employment in non-agricultural employment (harmonised series) of ILO.

Source: OECD Development Centre and ILO.

StatLink 게내 https://doi.org/10.1787/888934160627 


\section{Box 1.3. Labour market vulnerabilities in Emerging Asia (cont.)}

Finally, the pandemic is destabilising employment for overseas workers, including those who work at sea as manpower for cargo and cruise ships. This results not only in reduced remittances, and therefore lower purchasing power for dependent households, but also bring additional entrants into the land labour market. The Philippines, which received approximately 9.3\% of GDP in remittances in 2019 and has many nationals working overseas, is one of the most vulnerable countries in Emerging Asia in this respect (Figure 1.7). India, Cambodia and Viet Nam are likewise susceptible to the downturn in the employment situation abroad.

\section{Figure 1.7. Personal remittances and stock of nationals abroad, Emerging Asia} Percentage
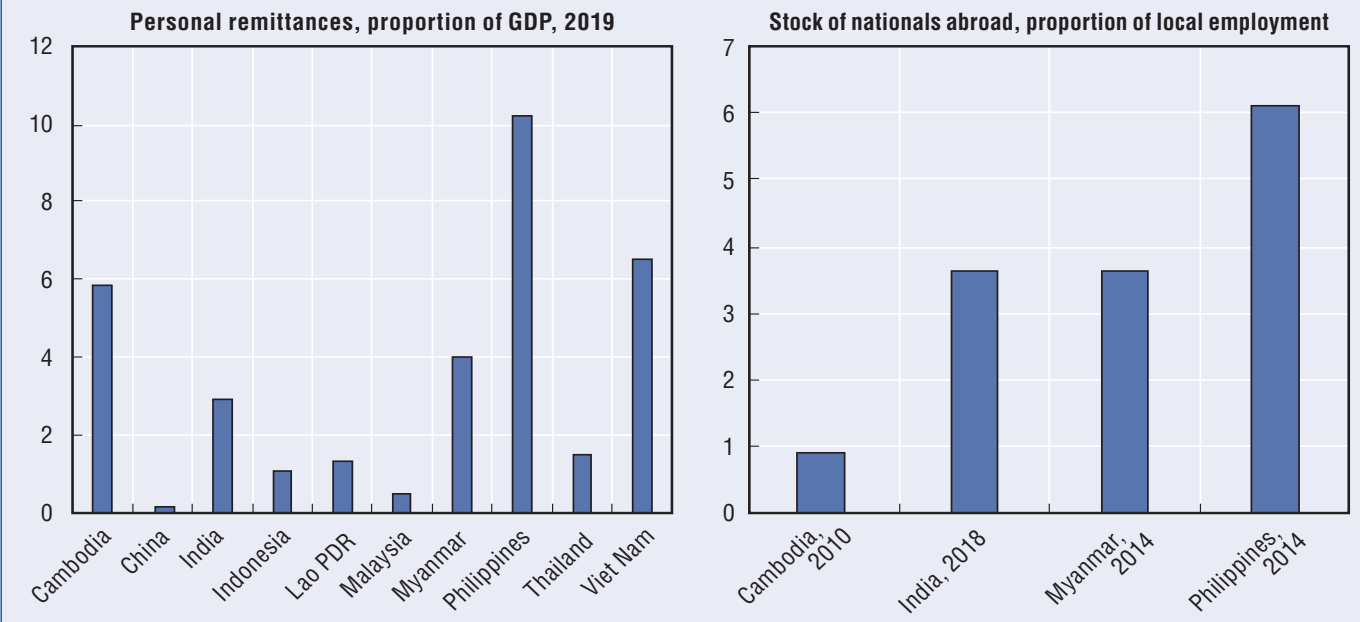

Note: The foreign nationals abroad data and total employment data are from ILO. For Myanmar, the foreign nationals data refer to 2014, while the total employment data refer to 2015.

Source: OECD Development Centre based on ILO; World Bank.

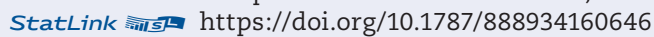

\section{Thailand}

Thailand has navigated the pandemic relatively well. Since peaking in March, COVID-19 cases have declined steadily. The government loosened business and movement controls in the first half of May, though a state of emergency remained in effect until the end of June, and travel restrictions remain in place as of 23 July. The country's first case was confirmed two weeks into January, and confirmed infections began to rise sharply in the second week of March. Border closures were imposed in the third week of March, followed by the declaration of a national state of emergency and imposition of curfews. Non-essential establishments were closed and the tight controls were observed for more than two months. As of early July, Thailand had over 3000 cases, with a case fatality rate of approximately $2 \%$. Cases are concentrated in the Bangkok metropolitan area, which accounts for roughly $50 \%$ of the tally. Bangkok produces a third of total economic output.

Although it seems that the Thai domestic market will be spared prolonged uncertainty, external markets are still far from stable. Given that the country is more integrated with the global economy than most other ASEAN economies in terms of trade and tourism, GDP is expected to contract in 2020 by about $6.7 \%$. Economic performance is projected to improve in the following year, when the domestic and global environments stabilise. National accounts data in Q1 2020 reveal a 1.8\% decline in GDP, continuing a downward 
trend from the previous quarter. Household spending momentum eased marginally, matched by a substantial downturn in exports. Government spending continued to decline as fixed investment shrank significantly. On the supply side, agricultural output decreased for a second straight quarter. The farm sectors in Thailand and other countries along the Mekong Delta have been contending with severe drought for months. The industry and the service sectors have been shackled by the trade war since last year and by the pandemicinstigated pullback in domestic spending and external shipments.

Growth could elude the economy until around the fourth quarter of this year. Trade and tourism prospects remain grim. The slump in the private consumption index in April was the steepest seen since 2010. Consumer pessimism is at its highest since 1998, while retail sales are down, as in other countries in the region (Figure 1.8). In the absence of a stable anchor, investment is likely to stay subdued in the near term. Much will depend on the efficacy of fiscal packages and monetary interventions to support domestic demand buoyancy for the rest of the year. The resumption of projects in the Eastern Economic Corridor would help spur economic growth. To support social welfare amid the pandemic, the government allocated roughly $8.3 \%$ of GDP for health-related spending; assistance to workers, farmers and entrepreneurs; and utilities, tax and social security payment relief (ADB, 2020). As for credit creation and direct lending, the interventions amount to $7.7 \%$ of GDP. Meanwhile, the central bank has pushed its already low policy rate even lower this year to facilitate market liquidity.

\section{Figure 1.8. Consumer confidence indices and retail sales growth in ASEAN-5, 2019-20}
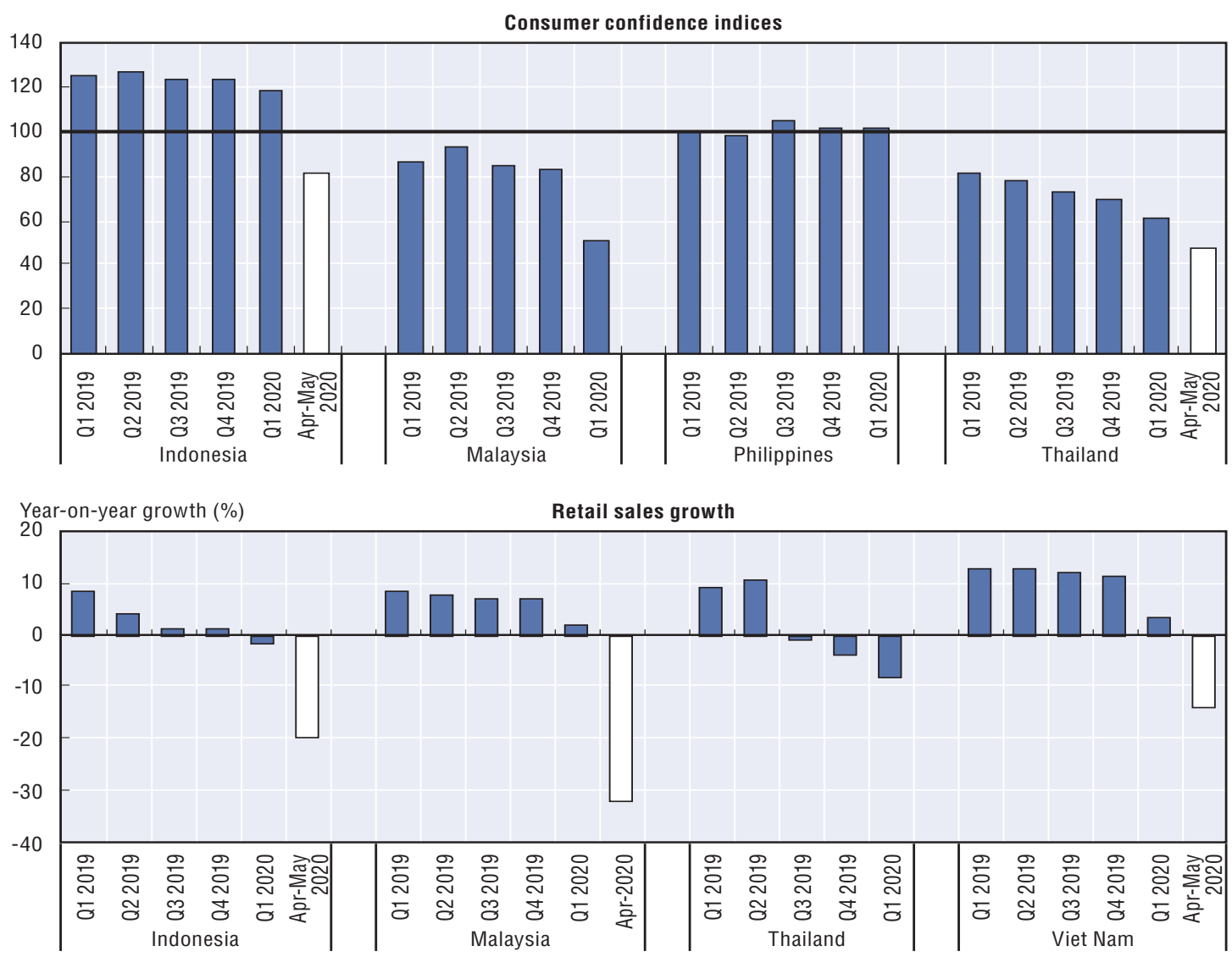

Note: The confidence indices are adjusted to set 100 as neutral confidence point. The data are as of 26 June 2020. Source: OECD Development Centre based on CEIC and national sources.

StatLink -inा ht https://doi.org/10.1787/888934160665 


\section{Viet Nam}

Viet Nam is on track for an exceptional outcome in public health crisis management despite its proximity to China and its comparatively limited resources. Viet Nam's first COVID-19 case was confirmed roughly a week before the end of January. The issuance of prevention guidelines and rapid mobilisation of testing and tracing were early steps, followed by border tightening, flight restrictions and mandated business closures on a gradual basis since early February. Nationwide movement restrictions were imposed on 1 April to slow the spread of the virus. The quick reaction appears to have paid off: as of early July, the number of confirmed cases stood at approximately 350 and the case fatality rate was nil. The government began relaxing quarantine measures in late April, including in Hanoi and Ho Chi Minh - the two cities with the highest concentration of cases. All domestic flights were allowed to resume around the same time following a partial reopening a week before. Transport restrictions were further relaxed later.

Viet Nam's economy is forecast to grow by $2.5 \%$ in 2020. Although this is lower than the growth projected in November 2019, the country will continue to lead ASEAN-5 in this respect. The rate of expansion is likewise projected to rise to $7.2 \%$ in 2021 , assuming no sizeable unforeseen shock occurs. In Q1 2020, GDP growth declined to 3.8\% from 7.0\% in the previous quarter. Manufacturing lost some momentum from previous quarters, while the services sector, a more stable growth driver in the past, was also deeply affected by the pandemic (Box 1.4). On the demand side, retail sales data suggest that private consumption has substantially weakened due to the health scare and movement restrictions. State investment has picked up to compensate for the fall in foreign capital inflows, based on FDI registration data. Meanwhile, nominal goods exports have held up well in the first three months of the year, anchored by a surge in offshore sales in February, just before most countries imposed their restrictions.

\section{Box 1.4. COVID-19 tests resilience of the services sector}

The services sector accounts for the largest share of economic output in Emerging Asian economies. In 2019, the sector's contribution ranged from just under $40 \%$ to nearly $70 \%$ of production in each country. The trend has been rising in many cases. This entails not only growing direct contribution to the economy, but growing input share in other sectors as well. Services input as a proportion of manufacturing's total inputs has generally risen between 2010 and 2017 in selected Emerging Asian economies (Figure 1.9). In contrast, the input share of other manufacturing sub-industries has mostly declined.

\section{Figure 1.9. Change in share of services and manufacturing in manufacturing total intermediate inputs in Emerging Asia between 2010 and 2017}

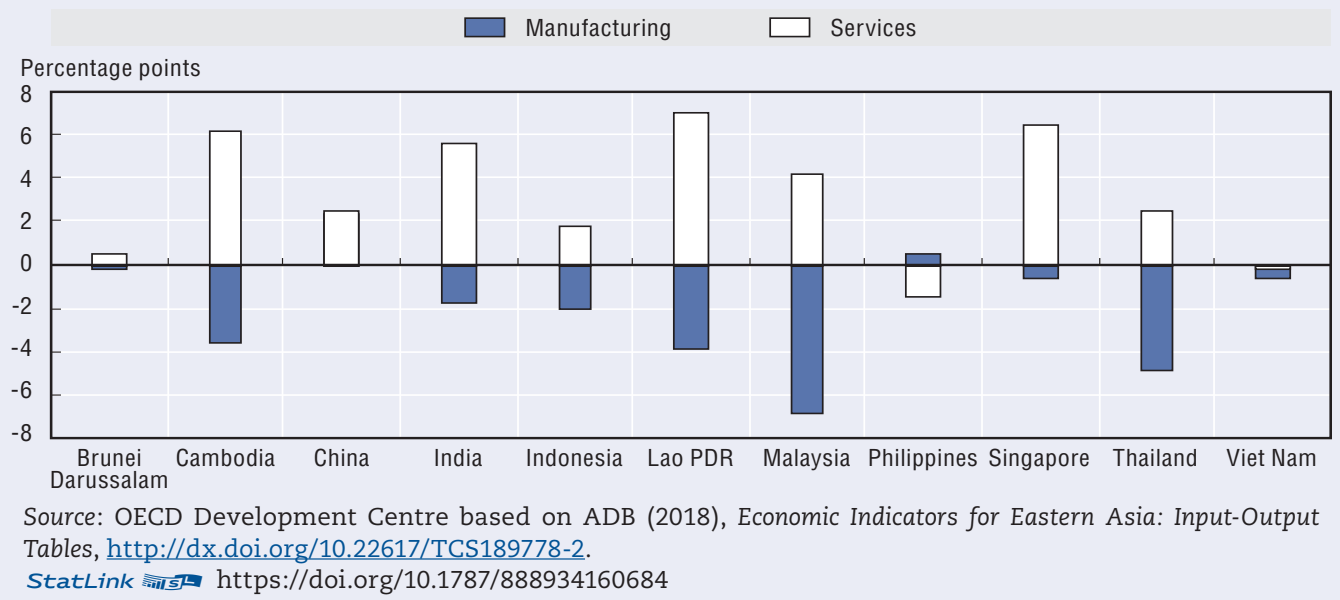




\section{Box 1.4. COVID-19 tests resilience of the services sector (cont.)}

The deepening of services penetration has arguably made the sector more robust in response to economic shocks. Moreover, while its share in inputs of export-oriented manufacturing has increased, the services sector has established a broader domestic market anchor. Our calculations using country input-output data reveal that the direct share of services in final domestic demand in the region remains substantially higher than its direct share in exports in 2017. When the US-China trade war erupted in 2019, services sectors were dented but generally remained stable even as manufacturing growth dipped in many countries.

The COVID-19 outbreak has weighed more heavily on the sector's growth, however, owing to the pullback in both domestic and external demand (Figure 1.10). The digital nature of some services helped the sector to stay afloat. E-commerce platforms maintained the flow of goods, although at a slower pace than before the imposition of quarantines and curfews. The use of digital finance averted potentially massive queues for physical cash on a daily basis. Digital services applications also enabled the continuous delivery of traditional services like health and education in some cases. This transformation within the services sector could underpin economic stability moving forward.

Figure 1.10. Manufacturing and services in selected ASEAN economies, 2016-20

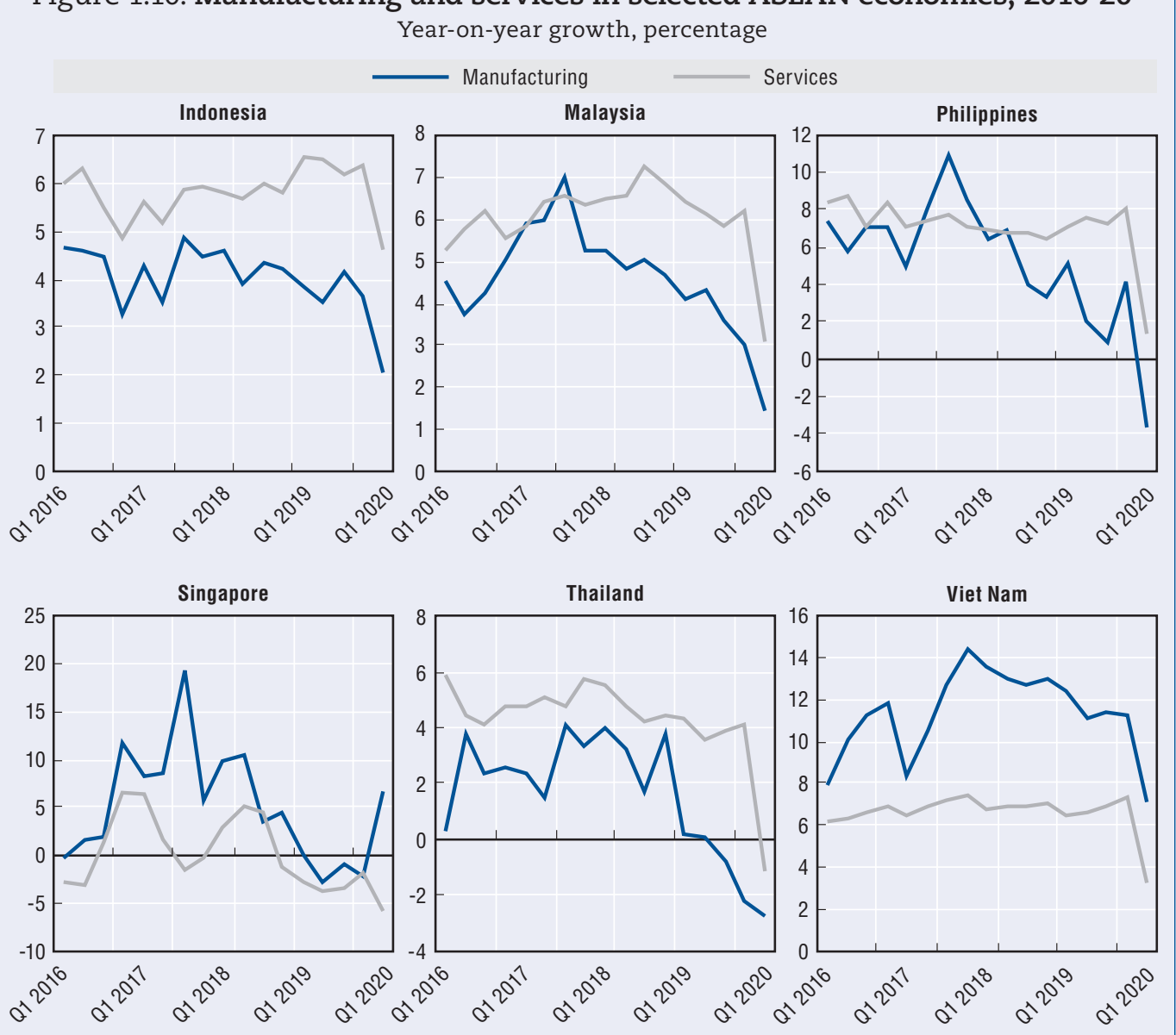

Note: Data for Viet Nam are year-to-date. The data are as of 26 June 2020.

Source: OECD Development Centre based on CEIC.

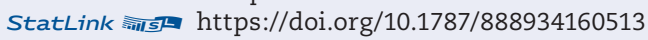


Box 1.4. COVID-19 tests resilience of the services sector (cont.)

Moreover, with the improvement in digital tools further enhancing the efficiency of delivery of various services - such as communication, accommodation, logistics, finance and retail trade - the "servicification" of economies will likely broaden in the coming years. Nonetheless, governments in Emerging Asia have substantial work ahead in terms of providing the necessary digital infrastructure and regulations, both domestically and regionally, to maximise potential gains from these developments.

With the gradual easing of restrictions, GDP growth in Viet Nam is expected to stabilise in the next quarter or two before picking up pace. The resumption of domestic flights in April bodes well for the travel and hospitality industries as domestic tourism could at least partially compensate for a massive drop in foreign tourist arrivals. Following the border shutdown, the number of overseas visitors fell by more than $98 \%$ in both April and May. Exports began feeling the global trade slowdown in Q2 2020. Even shipments to China, which expanded briskly from February to April, slowed in May. Viet Nam's broad-based fiscal intervention should help buttress economic growth. The national government allocation for COVID-19 containment measures, tax and duty deferrals, social protection programmes and related subsidies reached about $4.9 \%$ of GDP (ADB, 2020). On top of this, direct lending support and forbearance amounted to 5.2\% of GDP. A key and persistent concern is the health of the banking sector.

\section{Brunei Darussalam and Singapore}

\section{Brunei Darussalam}

Brunei Darussalam contained the spread of COVID-19 effectively with an early response and efficient tracing. The government began imposing travel restrictions in late January, more than a month before the country saw its first case. Policy on self-isolation, mass gatherings and a further tightening of foreign travel rules was subsequently rolled out. The government nonetheless avoided the tight restrictions on movement seen in other Southeast Asian countries. Some businesses remained operational even after confirmation of the first case, in the second week of March, while places where people tend to gather (e.g. schools, sports facilities and cinemas) were ordered to shut. Flexible work arrangements were encouraged. The fact that Brunei Darussalam and its capital Bandar Seri Begawan are less densely populated compared to neighbouring countries has also played a part in reining in the spread of COVID-19. As of early July, the number of infections stayed below 150 and only three deaths were reported.

The country ended 2019 on a very strong note after posting 7.1\% growth in Q4 2019. This was the fastest quarterly year-on-year expansion since quarterly data were made publicly available in 2004. Exports and private spending led the push in economic output during the quarter, as in the previous quarters last year (Figure 1.11). Nominal goods receipts in 2020 through March continued to rise significantly. Mineral fuel shipments were particularly strong. China and US nominal goods imports data in Q1 2020 also reveal a considerable increase in flows from Brunei Darussalam. Bank loans to the household sector in Q1 2020 slipped slightly from Q4 2019, but arguably remain robust. 


\section{Figure 1.11. Contributions to GDP growth by components in Brunei Darussalam and Singapore, 2018-20}

Percentage points
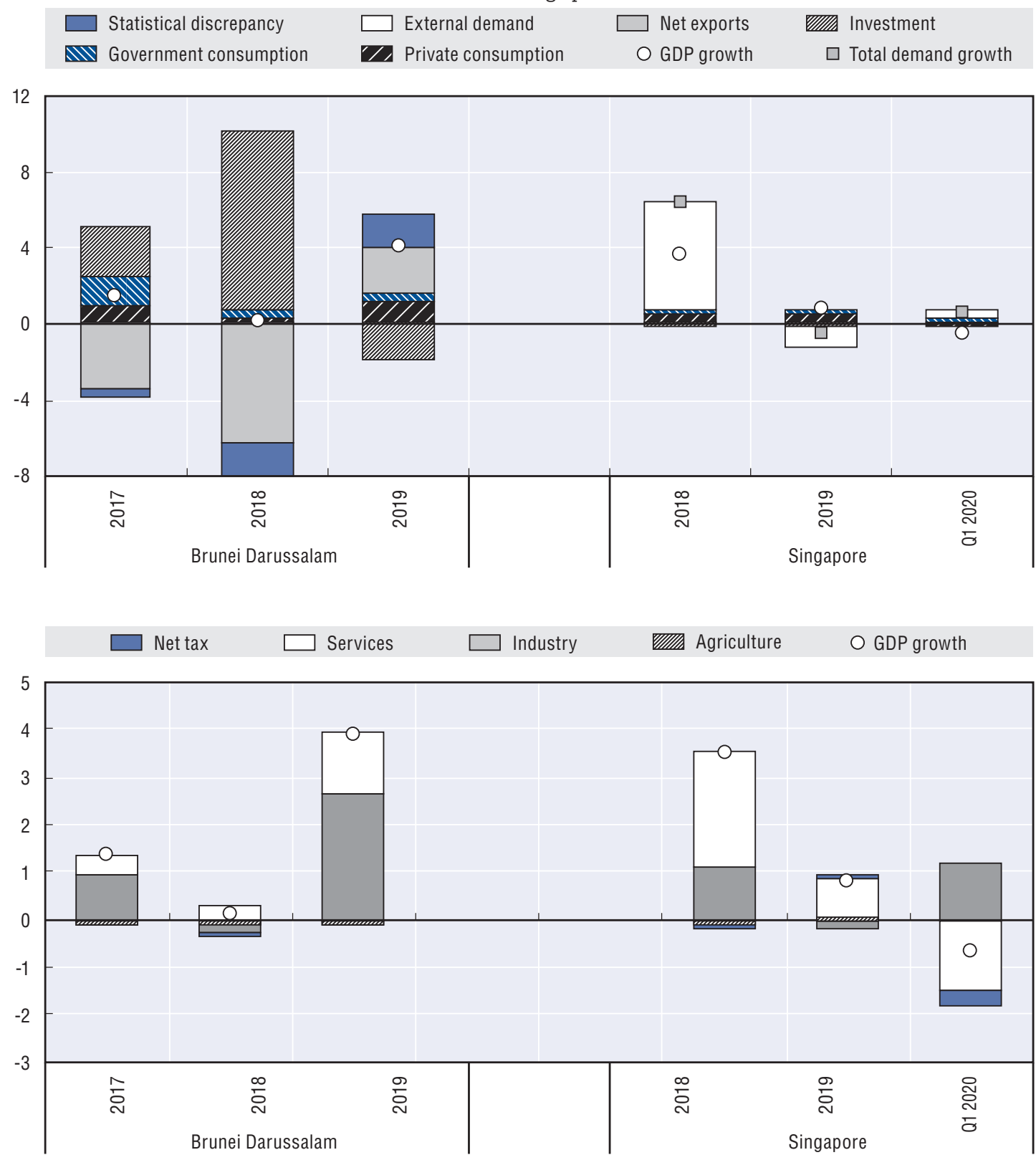

Note: The agriculture sector refers to agriculture, fisheries and forestry in the data compilation. For Singapore, the data series is chain-linked and the contribution to growth is not necessarily equal to GDP growth; agriculture refers to "Other Goods Industries" in the data compilation and includes quarrying; industry is comprised of manufacturing, utilities and construction; and services include ownership of dwellings. The data are as of 26 June 2020.

Source: OECD Development Centre based on CEIC and national sources.

StatLink 前占 https://doi.org/10.1787/888934160703

COVID-19 and the response measures are expected to impede domestic activity in Brunei Darussalam more strongly in the next two quarters. External factors, such as the falls in global oil prices and tourist arrivals, will also weigh on economic activity. On the upside, oil prices have been in sustained recovery since the end of April. The government 
has allocated extensive support, especially to micro-, small and medium-sized enterprises (MSMEs) (Ministry of Finance and Economy-Brunei Darussalam, 2020). This is vital not only for the domestic engine but also for continued private-sector expansion, a long-standing objective of the government. Fiscal measures have centred on assistance pertaining to tax, utility and social security payments of the hardest-hit households and firms (IMF, 2020a). Fiscal limitations could be a challenge over the long haul, however. The affected sectors were also granted a six-month deferment on their loan principal repayments. Against this backdrop, the country's GDP growth is forecast to decline to $1.4 \%$ in 2020 . A marginal rebound is expected in the following year when global conditions improve.

\section{Singapore}

Containment measures were implemented in Singapore as early as the first week of January, more than two weeks before the first case of COVID-19 was confirmed. Restrictions on travel to and from China were implemented when domestic cases were first suspected. Testing and tracing went into overdrive in the city-state in subsequent weeks. A stay-athome order was enacted, travel restrictions were broadened and education was gradually shifted to digital platforms. Contagion was contained until around the first week of April, when a second wave of infections occurred, affecting certain residential clusters. The transmission rate was significantly faster than in the first wave, but daily cases peaked after two weeks and have since gradually declined. As of early July, Singapore had around 42000 confirmed cases, albeit with the lowest case fatality rate among ASEAN economies with registered fatalities, at less than $0.1 \%$. These two figures are a testament to the testing capacity and healthcare quality.

A contraction of $4.4 \%$ in GDP is forecast in 2020, owing to the global trade and tourism downturn that affects an array of services and industrial subsectors. If it materialises, it will be Singapore's first annual contraction since 2001. GDP growth is forecast to swing back to positive territory in 2021, assuming that global conditions improve. Data in Q1 2020 reveal a dip of $0.7 \%$ in economic output from the previous year. The last time the country posted a quarterly year-on-year drop was in Q2 2009 during the global financial crisis. Manufacturing output growth swung upwards after retreating in the past three quarters. Production of biomedical goods, precision engineering and transport engineering registered strong growth during the period (MTI Singapore, 2020). While the informationand-communications and financial services subsectors continued to grow, most other services clusters fell into the red. On the demand side, private consumption and exports came in weak, as in Emerging Asia as a whole (Figure 1.12). Government spending and fixed investment partially absorbed the slack to buoy economic activity.

Prospects for the rest of the year remain feeble. The manufacturing PMI moderated further in April and May 2020, while retail sales plunged deeper. Foreign visitor arrivals, which plummeted in February and March, practically halted in April and were not expected to grow until a few months after the lifting of movement restrictions (Box 1.5). As in other ASEAN economies, nominal goods exports fell sharply in April and May. The government's sizeable fiscal package should buttress private consumption and businesses' financial standing. Health spending related to COVID-19, tax and tariff adjustments, social protection measures, wage subsidies and other interventions amount to an estimated $7.9 \%$ of GDP (ADB, 2020). Around $7.7 \%$ of GDP in additional lending support was also made available. The interventions arguably helped lower bankruptcy applications in the city-state in April and May from a year ago, after applications increased by almost 70\% year-on-year in Q1 2020. However, despite incentives to keep workers employed, it may take time to reverse displacement, particularly of repatriated foreign workers. 
Figure 1.12. Private consumption and gross exports, real year-on-year growth Percentage

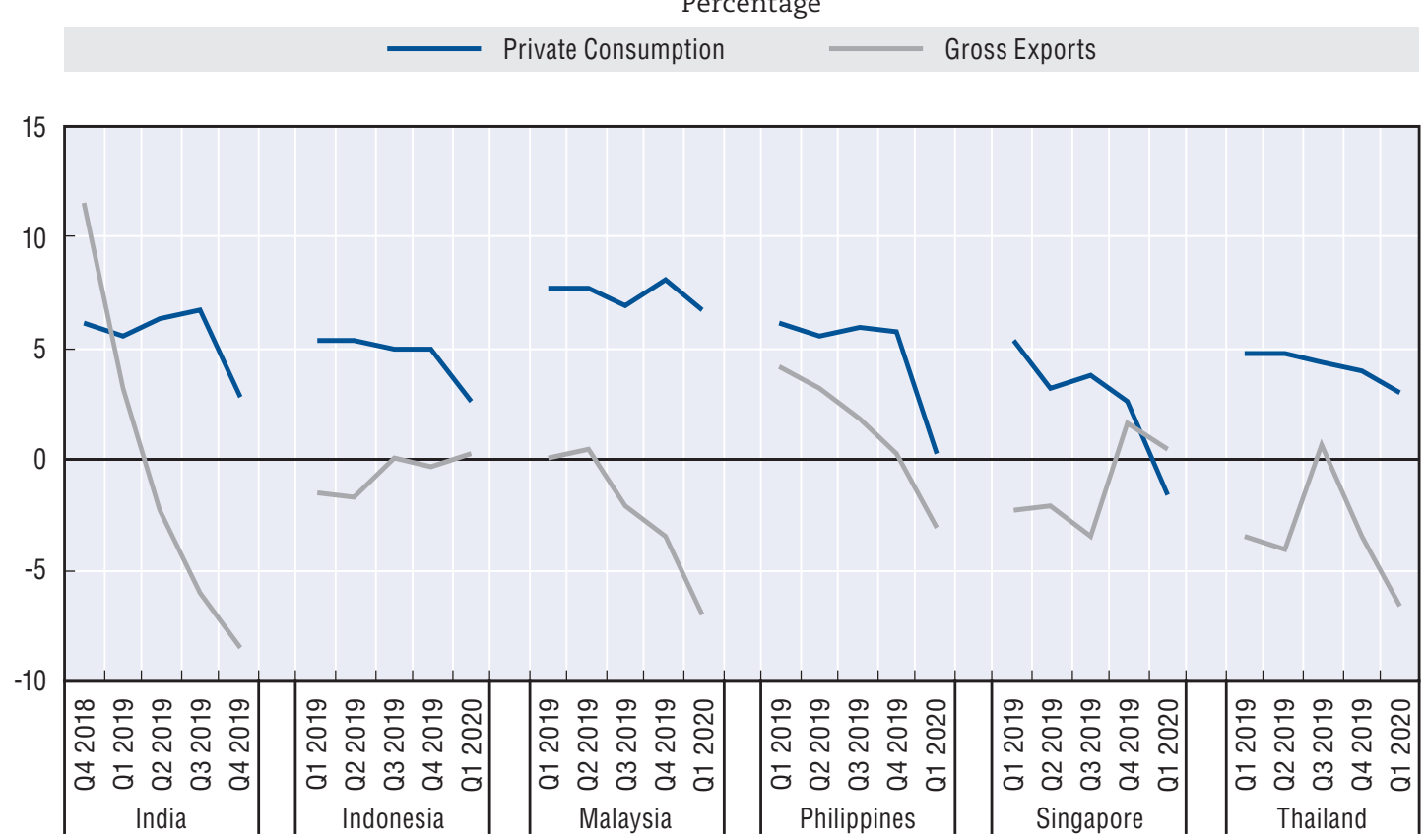

Note: Data for India relate to fiscal years. The data are as of 26 June 2020.

Source: OECD Development Centre based on CEIC and national sources.

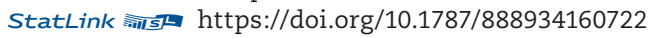

\section{Box 1.5. Rough waters for tourism and trade in Emerging Asia}

As the COVID-19 pandemic ushered in border closures and travel restrictions, tourist arrivals in Q1 2020 declined by 18\% to 43\% in Emerging Asian countries where data are available (Figure 1.13). The drop was even steeper in April and May due to broader flight and border restrictions. In Indonesia, foreign arrivals slumped by close to $90 \%$, while in Cambodia, Singapore, Thailand and Viet Nam arrivals were restricted to those that were essential, or prohibited outright. Domestic tourism, a channel at least as significant as foreign tourism, was also squeezed. Though per-visitor spending may be lower than for international tourists, the number of local people travelling within the country is far higher, particularly in India, China and Indonesia (UNWTO, 2020).

Border closures also affect trade, and nominal merchandise exports, which reeled in 2019 from the US-China trade tension, face another significant shock. Data in April and May indicate a broader downturn than in Q1 2020 across Southeast Asian economies. The depth of decline varies, possibly due to differences in ground conditions, response timelines and the tightness of restrictions. The Philippines appears to be most affected among ASEAN economies. The country's export earnings in April shrank by more than half on a year-on-year basis. 
Box 1.5. Rough waters for tourism and trade in Emerging Asia (cont.)

Figure 1.13. Tourist arrivals and goods exports growth in Southeast Asia, 2019-20

Percentage

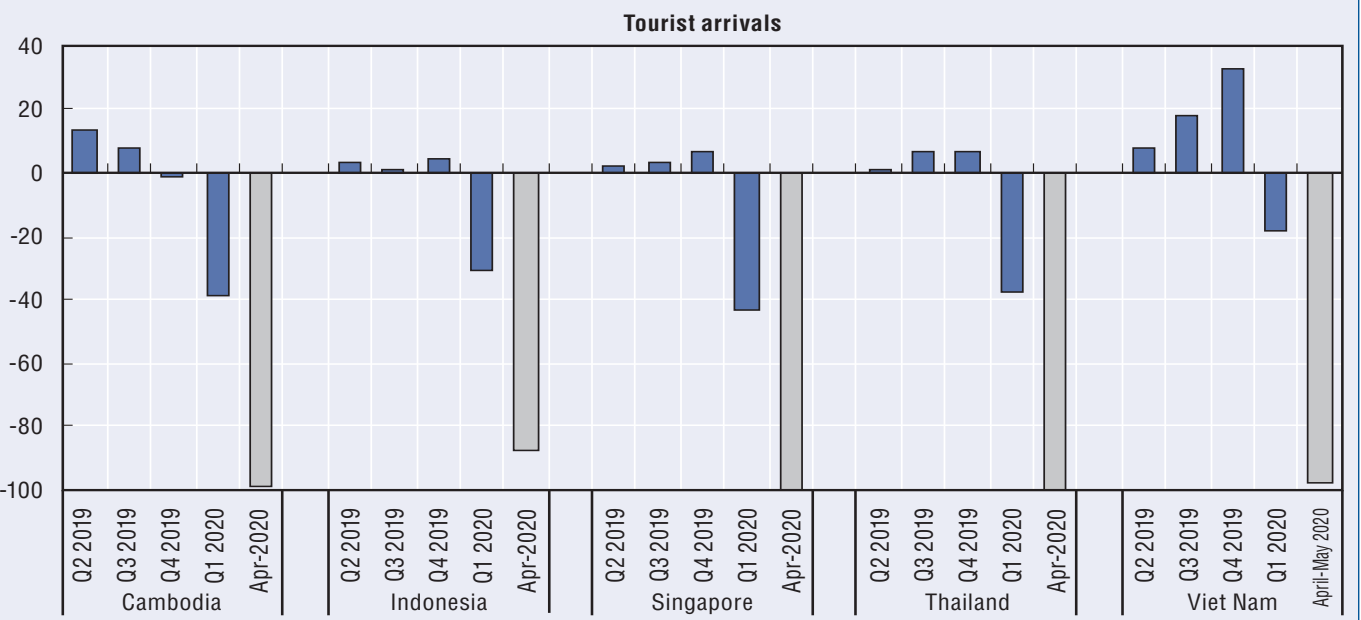

Goods exports

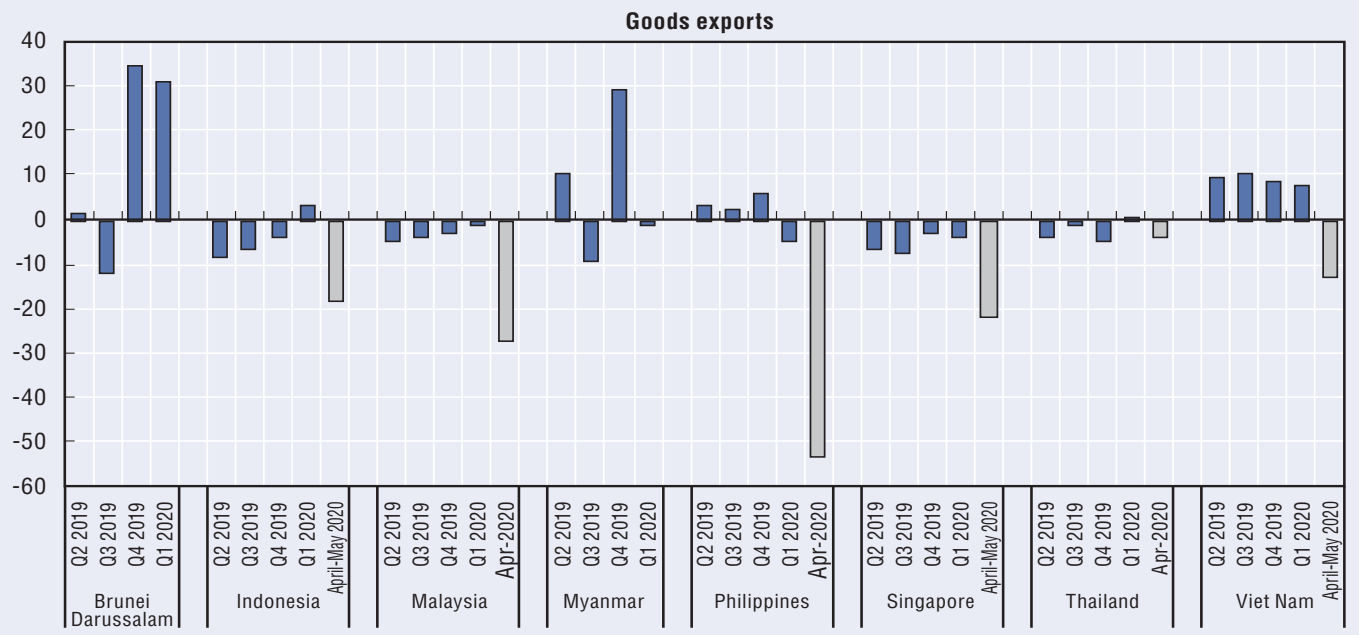

Note: The base levels of exports are in US dollars and follow the calendar year, including Myanmar. The data are as of 26 June 2020.

Source: OECD Development Centre based on CEIC and national sources.

StatLink 形) https://doi.org/10.1787/888934160741

\section{Cambodia, Lao PDR and Myanmar}

\section{Cambodia}

Cambodia is weathering the COVID-19 health crisis comparatively well five months after the country's first case was recorded in late January. A climb in cases that began in March was arrested in mid-April, with numbers rising again since mid-May. Response measures included advancing the school break, cancelling Cambodian New Year celebrations, foreign travel restrictions, the closure of businesses where people congregate and a ban on mass gatherings. A state of emergency was enacted at the end of April to grant the prime minister sweeping powers to deal with the health risk. As of early July, the number of confirmed cases is around 150, with no deaths. Cambodia is one of two countries in Southeast Asia with no fatalities from the virus. 
Nonetheless, economic prospects in 2020 are strained. Leading indicators reported by the government suggest a weakening cycle (Ministry of Economy and Finance of Cambodia, 2020). Goods exports grew in the first four months of 2020 but slowed from the same period in the previous year. Incidentally, the European Union (EU) suspended part of Cambodia's trade preference status under the Everything but Arms programme in February 2020, effective in August unless objections are raised (European Commission, 2020). Foreign tourist arrivals in Q1 2020 shrank by more than a third and the reduction deepened considerably in April. Moreover, the Ministry of Economy and Finance report noted that while the total value of proposed projects has risen, approved private investment outside of special economic zones has declined. The effectiveness of assistance intended to keep the labour market buoyant will be material for sustaining private consumption, the key demand driver in recent years (Figure 1.14). The national government package for health spending related to COVID-19, tax and other fee exemptions, and other forms of subsidies and financial assistance, is estimated to represent about $0.6 \%$ of GDP based on nominal data (ADB, 2020). A more general package to support the labour market and revive the economy amounted to about $7.5 \%$ of GDP. In light of the circumstances, GDP is projected to decline by $1.0 \%$ for the year before registering a more buoyant growth rate in 2021.

\section{Figure 1.14. Contributions to GDP growth by components in Cambodia, Lao PDR and Myanmar, 2017-19}

\section{Percentage points}

$\square$ Statistical discrepancy
$\square$ Get exports Investment $\quad \square$ Total consumption
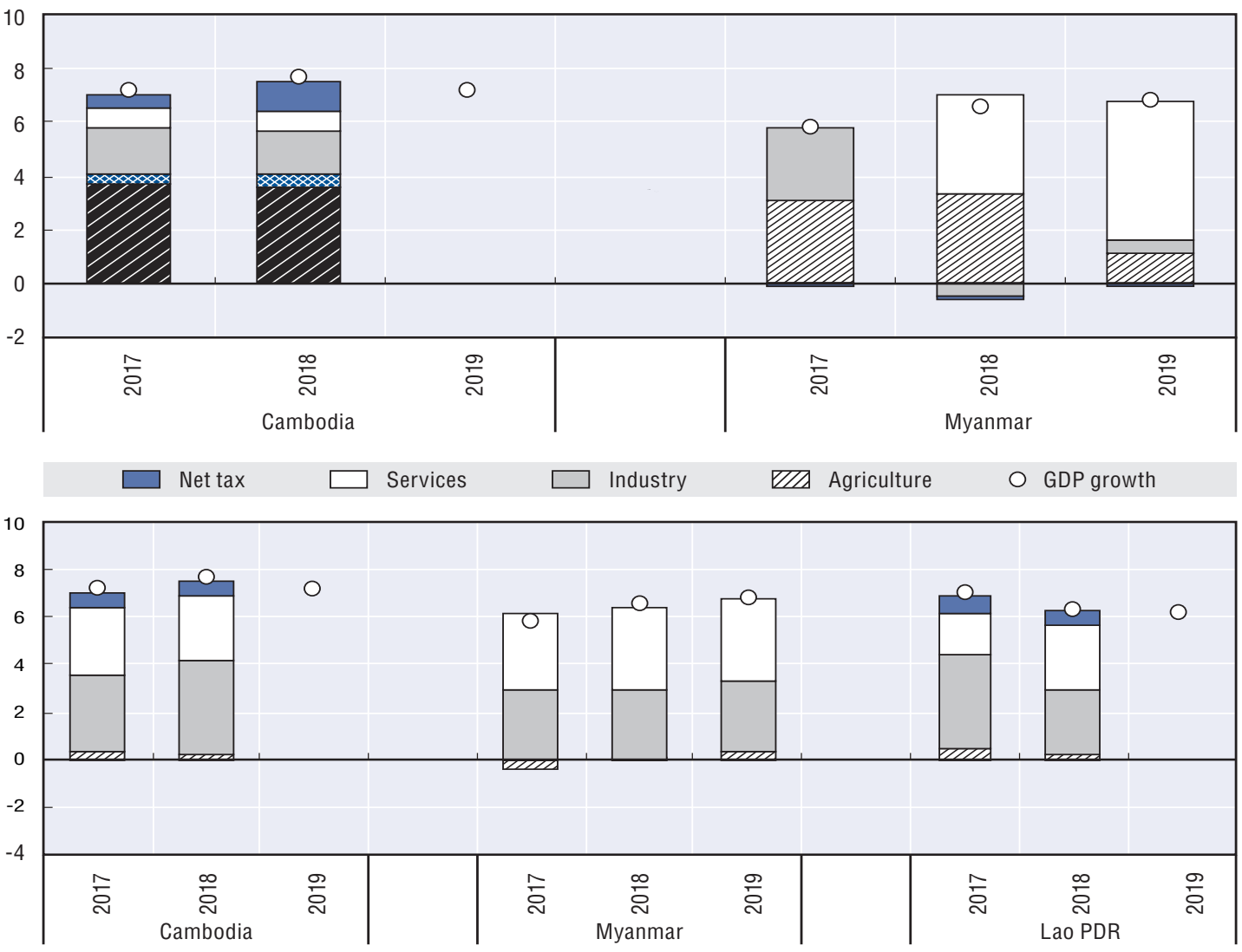

Note: The agriculture sector refers to agriculture, fisheries and forestry in the data compilation. Net tax equals gross tax minus subsidies. For Myanmar, total consumption equals private consumption plus government spending, and data relate to fiscal years ending in September. Lao PDR, 2019 GDP growth rate is an estimate and demand-side data are not published. The data are as of 26 June 2020.

Source: OECD Development Centre based on CEIC and national sources.

StatLink 尚is ht htps://doi.org/10.1787/888934160760 


\section{Lao PDR}

Lao PDR's response to the threat of COVID-19 was similarly effective in limiting infections, especially given its borders with several countries including China and the limitations of its public coffers. The first local case of COVID-19 was confirmed in the last week of March. A few days later, the government issued nationwide containment measures that included a stay-at-home order, prohibition of mass gatherings, closure of non-essential businesses and border controls. The number of confirmed cases plateaued at 19 in the second week of April and there were no fatalities as of early July. Gradual re-opening of businesses began in the first week of May, and schools and sporting activities resumed, with strict measures in place to prevent the spread of the virus.

The country will remain one of the fastest growing economies in the region in the nearterm despite the slowdown. GDP growth is expected to settle at $1.0 \%$ in 2020 and reach $5.0 \%$ in 2021. The pullback in regional economic activity does not bode well for Lao PDR's electricity exports in the coming quarters: the protracted severe drought in the lower Mekong region has strained power generation in addition to agricultural production in the first half of the year. On the upside, exports to China - its main market - appear to be holding up very well, based on China's goods import data this year through April. The impact of disruption of domestic activity will also be milder overall than in most ASEAN economies in light of the more limited spread of the virus. Bank lending activity will nonetheless be tempered by rising provisions for nonperforming loans. Commercial bank lending, which was already slowing at the end of last year, remained lacklustre in Q1 2020.

\section{Myanmar}

Restrictions to business and social activities remain tight in Myanmar as threats of viral transmission persist. Schools remained closed in mid-July. A suspension of international flights and other containment measures were extended in late June until mid-July. The government set up a crisis management committee in mid-March and an independent task force later to conduct contact tracing, among other tasks. The first case was logged in late March just before the disease was detected in neighbouring Lao PDR. After a few days of gradual increase, the number of cases began to rise more sharply. The curfew and stay-at-home orders imposed in mid-April in Yangon presumably aided in stemming the tide. As of early July, the number of confirmed cases stood at approximately 300, with six fatalities. Security issues remain a considerable challenge in pursuing health and economic recovery policies moving forward.

GDP growth in fiscal year 2020 (ending September 2020) is projected to come in at $2.0 \%$, which is substantially lower than the rate in the previous year and our forecast in November 2019. Greater expansion is expected in FY 2021 when industry and services operate at full capacity for the entire year. These two sectors produce more than three-quarters of total output and contribute the most to the country's economic expansion. Export value grew by more than $10 \%$ in the first half of the fiscal year (October-March), although exports have wavered in recent months. Shipments to China, the country's top export market, remained solid through March 2020 before pulling back in April, based on China's import data. Strong FDI inflow in Q1 FY 2020 (October-December) is also confronting rising business climate uncertainties. Myanmar's ongoing power projects will be crucial for increasing the production base in the next few quarters, as well as for lowering the cost of electricity for households, particularly those outside major cities. Domestic consumption will likely decline slightly this year, largely owing to restrictions on movement and enterprise activity. To support the struggling economy, the government has allocated funds to strengthen the health response, pushed back tax payment deadlines, reduced customs duties, offered soft loans to businesses and provided income support, among other measures (IMF, 2020a).

\section{China and India}

\section{China}

Despite cautiousness following a second flare-up of cases in some provinces as well as in the capital, China is continuing to wind down its stringent containment measures and pave the way for an economic restart. Schools and businesses have gradually reopened. Domestic tourism 
is showing signs of revival and the number of foreign flights entering the country has increased, although pandemic-induced overseas travel risks still prevail. The world's first case of COVID-19 was detected in December 2019 in the city of Wuhan. The number of cases slowly climbed for a few days, with the first fatality reported in early January. Transportation thoroughfares in the city were shut roughly a week before the end of January to allay growing concerns. Quarantines and travel restrictions followed elsewhere. The spring break was extended, effectively pushing back the resumption of work in many areas, and the opening of schools was postponed. Confirmed infections in China plateaued at nearly 80000 around the end of February and the overall health situation began to stabilise from that point onwards. Wuhan, which posted the highest number of cases and deaths in China, was opened in April. As of early July, approximately 85000 people were reported to have caught the virus in China, approximately 5.5\% of whom had died.

China's GDP is projected to decline by about $2.6 \%$ at the end of 2020 in the country's first economic contraction since the 1970s. Economic expansion is expected to resume in 2021 at a rate of 6.8\%, assuming economic engines will be operating at full scale. In Q1 2020, GDP shed $6.8 \%$, the sharpest downturn in decades. This represents the first year-on-year quarterly decline in growth since the official series started in 1992. Key supply- and demandside components shrank in general (Figure 1.15). On a more positive note, while containment measures slowed the economy to a virtual standstill, they also gave breathing space to the environment (Box 1.6). This applies not only to China, but globally (Bauwens, et. al., 2020).

Figure 1.15. Contributions to GDP growth by components in China and India, 2017-20 Percentage points
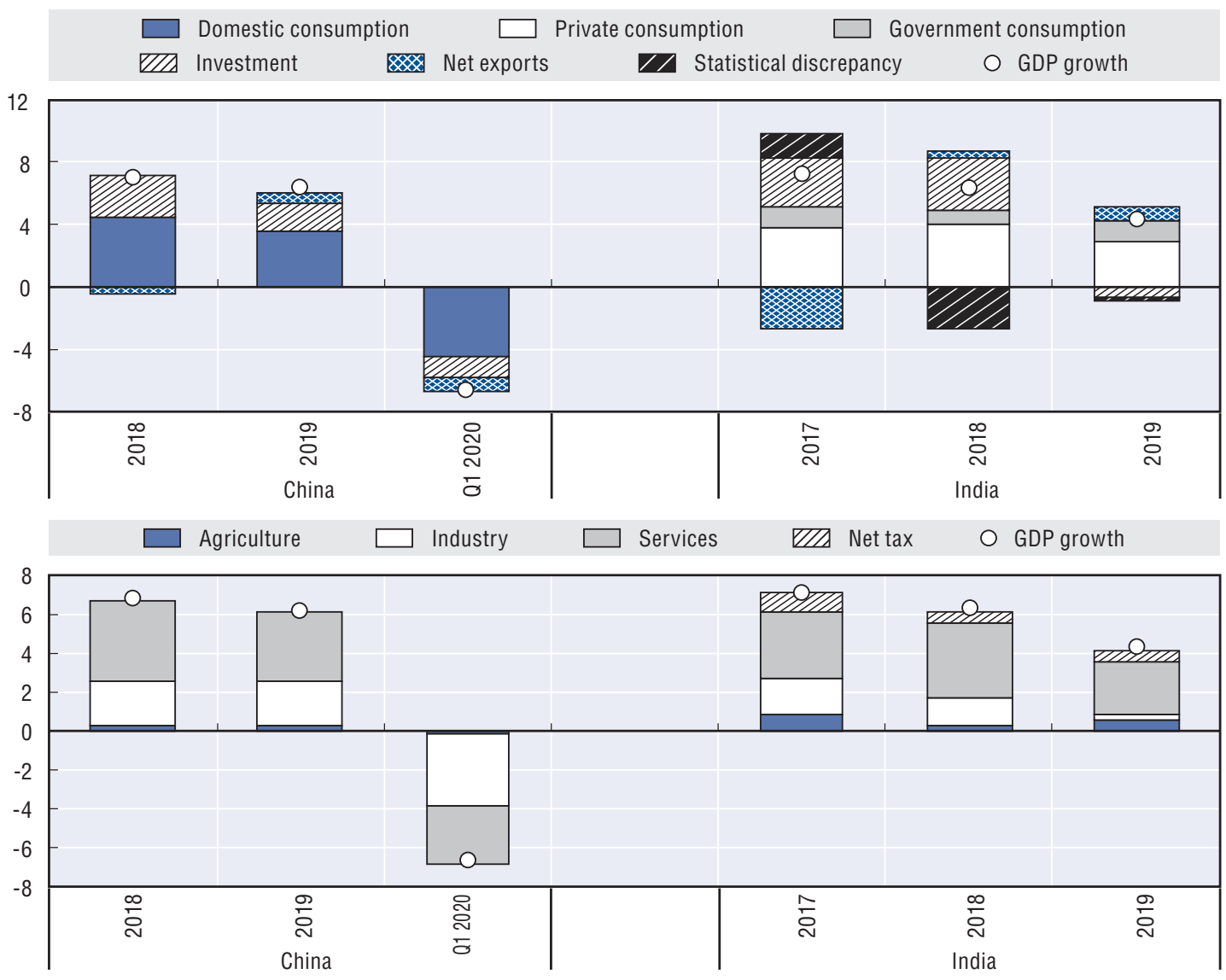

Note: The agriculture sector refers to agriculture, fisheries and forestry in the data compilation. Net tax equals gross tax minus subsidies. For China, domestic consumption equals private consumption plus government spending. For India, data relate to fiscal years ending March. The data are as of 26 June 2020.

Source: OECD Development Centre based on CEIC and national sources.

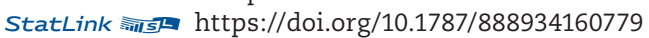




\section{Box 1.6. Air quality improves as activity slows during pandemic}

The challenging period of economic recovery from the COVID-19 pandemic provides a critical opportunity for policy makers to advance green investment and environmental sustainability.

Development in Emerging Asia has resulted in a deterioration of environmental conditions, especially air quality. During the pandemic, air quality improved due to restrictions on movement that lowered emissions. For example, the Himalayas became visible again from certain parts of India. Residents reported that the smog cleared during the government's 21-day lockdown, allowing them to see the towering peaks from Punjab, 125 miles away, for the first time in 30 years.

In China, many people stayed at home following the COVID-19 outbreak. Some factories ceased production, telework became commonplace and schools, restaurants and cinemas were closed. Vehicular traffic reduced significantly in the process, and air quality improved, with the concentration of particulate matter (PM 2.5) declining sharply in February 2020 in four areas where data are monitored (Figure 1.16).

Figure 1.16. PM 2.5 concentration in China, February 2019 vs. February 2020

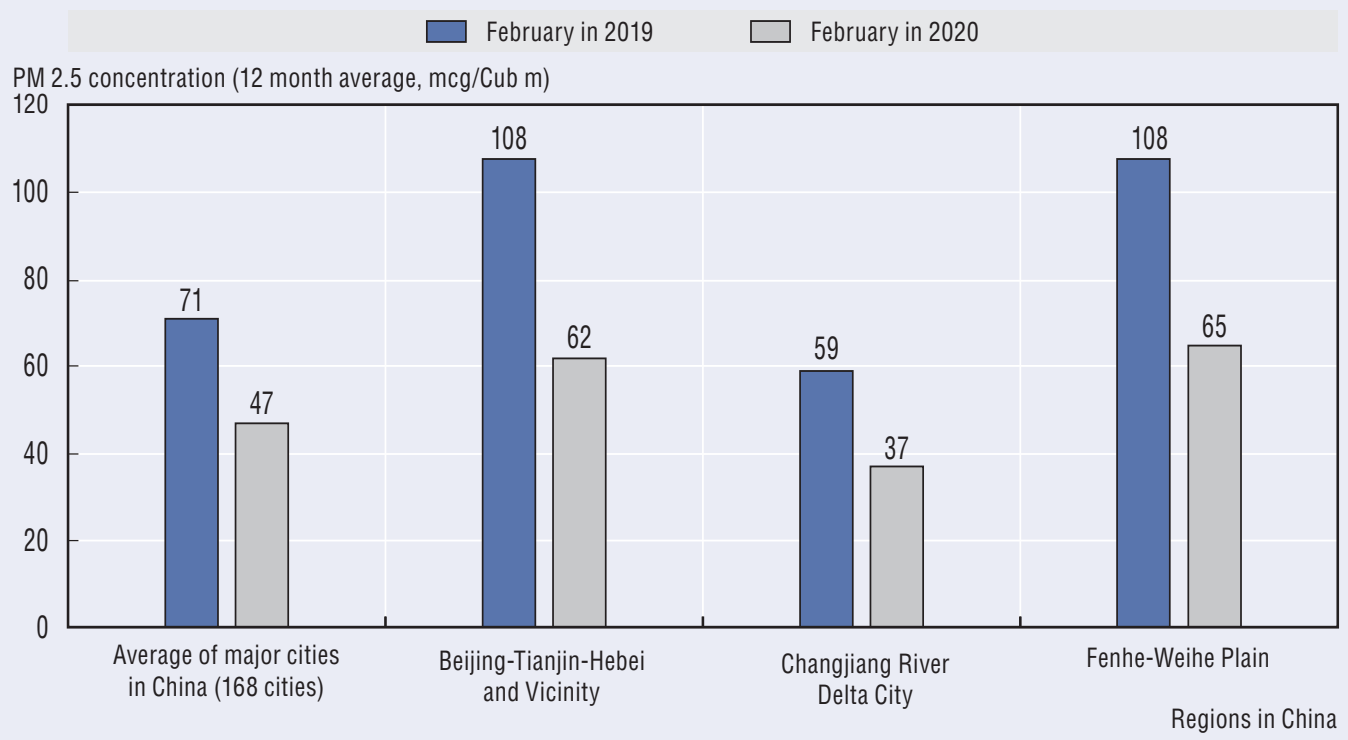

Source: OECD Development Centre based on CEIC and national sources.

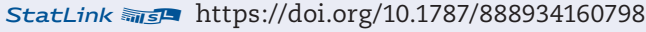

Leading indicators in April and May show signs of nascent recovery in China. Technology-based emerging sectors are paving the way for an economic rebound, with the value added of high-tech manufactured goods increasing markedly (National Bureau of Statistics of China, 2020a; 2020b). There is also a budding resurgence in some high valueadded services subsectors, led by information transmission, software and information technology services. Online retail sales of goods were reported to have expanded in the April-May period. This is matched by a robust rate of investment expansion in e-commerce services together with scientific and technological research. Investment in fixed assets is still weak, with construction activities regaining their footing. Sales of real estate and 
FDI utilisation similarly remain in a contractionary cycle. On the external front, nominal goods exports recovered in April. Shipments of high-tech products as well as medical and pharmaceutical supplies were notably strong. However, the recovery proved to be short-lived, with receipts falling again in May. With the trade tension still dominating the external landscape, prospects remain muted and expose other countries in the region to negative spillovers via the global value chain (Box 1.7). Interestingly, COVID-19 appears to have halted a divergence in China's export growth trends that was largely induced by trade policies in 2019 (Box 1.8).

China implemented various interventions to keep the social fabric intact and enable the economy to recover smoothly. The central bank lowered policy rate guidance and the reserve requirement ratios of commercial banks to buoy credit flows. Containing bankruptcies and mitigating their financial market impact is a critical challenge. In this respect, deeply entrenched shadow banking, although reduced in recent quarters, can be a double-edged sword. While it can facilitate credit flows to support the recovery, it can also create considerable risks should bankruptcies snowball or in the event of another large wave of infections.

\section{Box 1.7. Implications of COVID-19 for global value chains in Emerging Asia}

China, a major global producer of industrial commodities and components, has substantially contributed to the reshaping of the global production network since its accession to the World Trade Organization in 2001. This led to greater trade interdependence between China and other emerging economies in producing final goods. For example, in 2017, more than $35 \%$ of inputs to Viet Nam's manufacturing export commodities came from China. Similarly, more than $20 \%$ of inputs to the manufacturing exports of Cambodia, Lao PDR, Indonesia and India were sourced from China (Figure 1.17). The way COVID-19 has dragged down China's trade is expected to have a profound knock-on effect on the exports of Emerging Asian countries, both directly and through the regional value chain.

Forward and backward stream linkages give an idea of how disruption of the value chain will expose the trade positions of Emerging Asian economies at the global level. The Philippines has the highest global value chain (GVC) participation among Emerging Asian economies, according to data from the United Nations Conference on Trade and Development (UNCTAD, 2020). The country also has the highest foreign value-added content share in its exports and the highest domestic valueadded contribution share in intermediate goods re-exported to another country. Singapore has a relatively high level of GVC participation, followed by Malaysia and Thailand. Looking ahead, it is important to recognise that policy co-ordination among countries in the region will greatly help to mitigate the economic cost of the health crisis. 


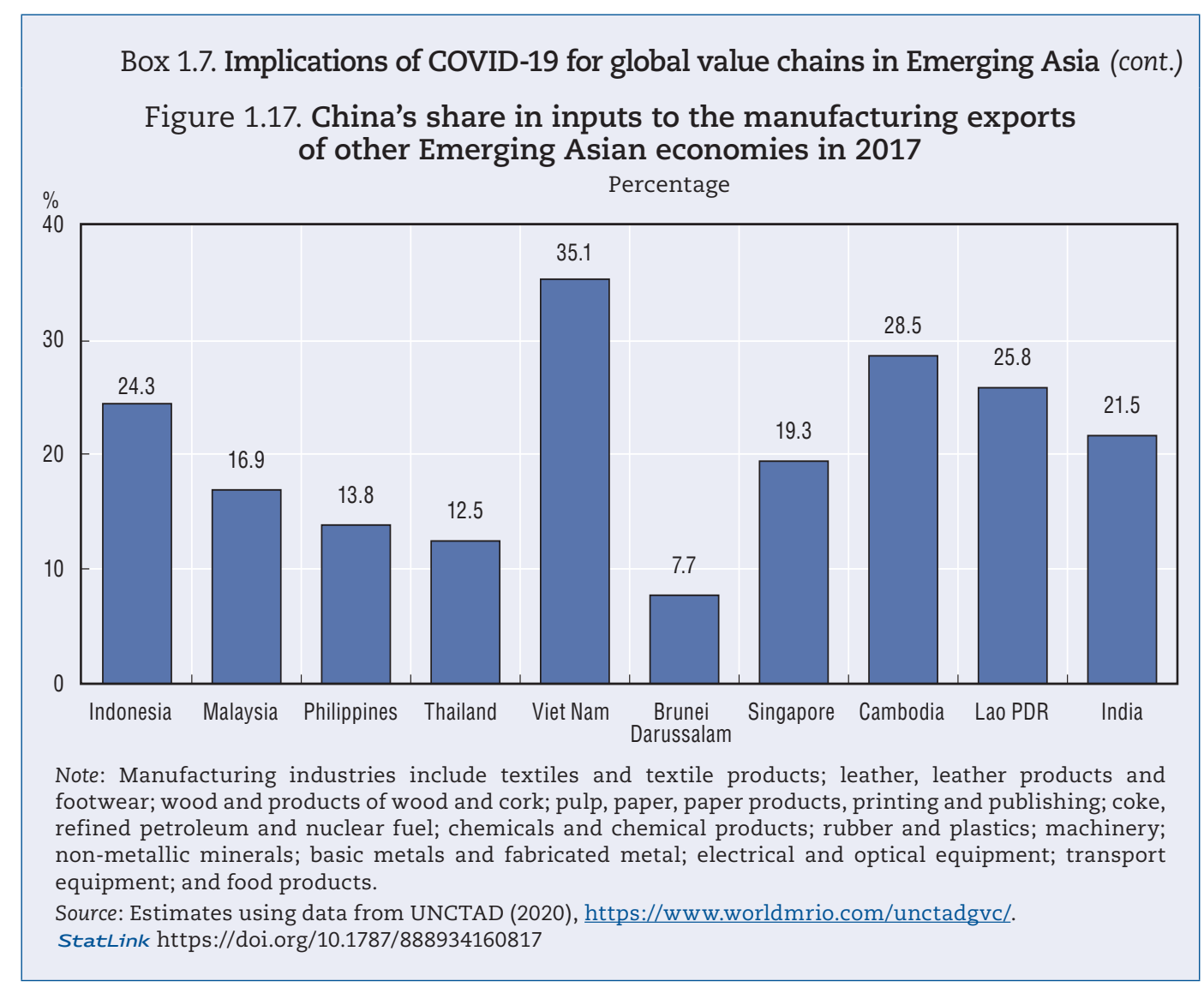

\section{Box 1.8. The evolving patterns of China-US trade}

China's merchandise exports inflected upwards in April after a tumultuous first quarter owing to border and merchandise inflow restrictions. However, the trend marginally reversed in May. A seeming respite from the trade war in late 2019 was cut short when COVID-19 spread globally, and exports to all major trading markets eased considerably before the April uptick (Figure 1.18). Exports to the United States and Europe appear to have moved past the trough, although they are still weak.

Apparent diverging export growth trends since mid-2019 - for example, falling growth with the United States and rising growth with ASEAN and Africa - have somewhat reconverged, suggesting another potential shift in the trade pattern. The protracted trade skirmish paved the way for the US share in China's exports to decline by about 3 percentage points between December 2018 and May 2020 on an annualised basis. During the same period, ASEAN's share increased by roughly 2 percentage points. 


\section{Box 1.8. The evolving patterns of China-US trade (cont.)}

Figure 1.18. China's goods trade by partner, 2018-20

Year-on-year growth, nominal 3-month moving average, percentage

- Africa L Latin America -..... EU - - - ASEAN - - - India

Exports

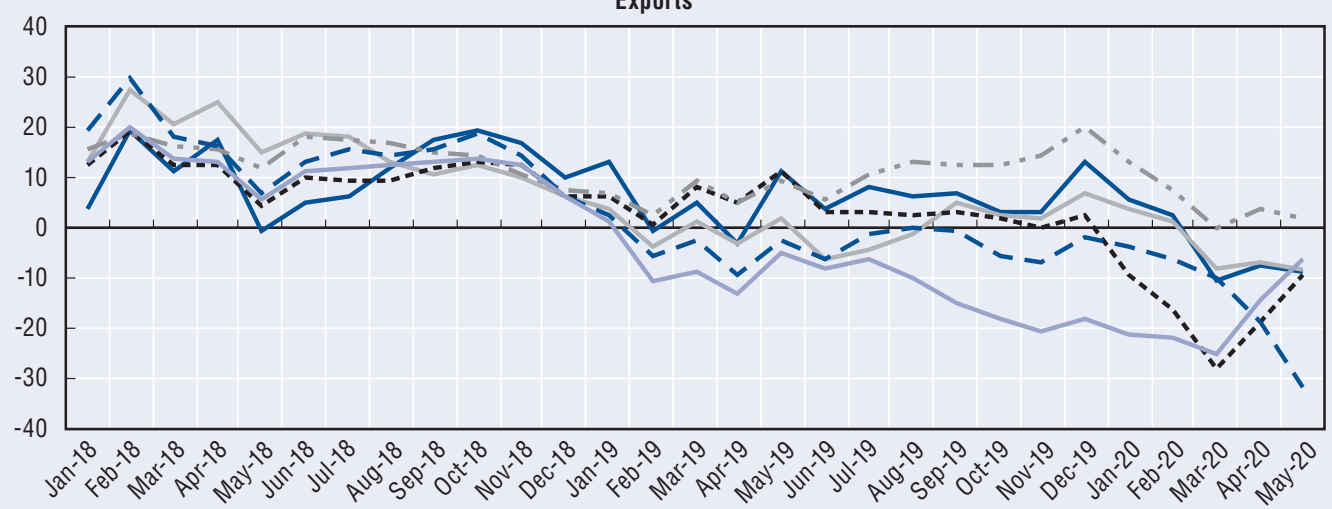

- Africa — Latin America -.--. EU - - - ASEAN - - - India - USA

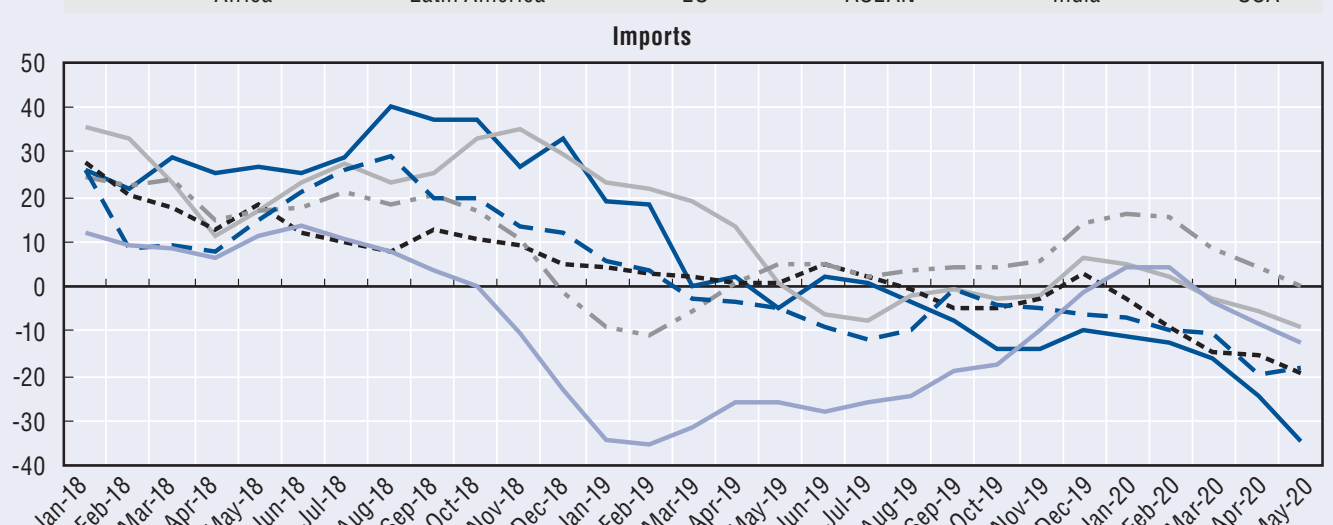

Note: The data for January and February 2020 were calculated using February 2020 year-to-date data and the distribution in January and February 2019. Africa, EU and Latin America aggregations were provided by the source. Latest data are as of May 2020.

Source: OECD Development Centre based on CEIC.

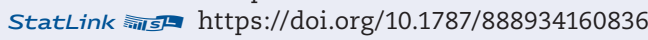

Imports from some of China's key partners have similarly pulled back. Imports from ASEAN are seemingly relatively more stable than from the other economic blocs (Figure 1.18). Purchases of food and live animals for consumption have been particularly robust, presumably because an outbreak of African swine fever squeezed the output of local farmers.

China's imports from the United States went into an upward trajectory as well from around Q4 2019, before the pandemic-induced dip, as policy compromises softened tensions somewhat. US tariffs on Chinese goods, due to be enforced in October and December 2019, were set aside, and a phase-one trade deal was signed in January 2020, taking effect the following month. However, it is posited that the targets of the phase-one deal will likely be missed given current trends (Bown, 2020). 


\section{Box 1.8. The evolving patterns of China-US trade (cont.)}

Meanwhile, US imports data suggest that divergence continues (Figure 1.19). As imports from China and India, together with South and Central America and Africa, trend downwards, the value of goods shipments from ASEAN are rising. Country-level breakdown of ASEAN aggregates reveals that not all countries in the bloc are reaping the gains. Brunei Darussalam, Cambodia, Malaysia, Myanmar, Singapore and Thailand appear to have benefitted more from the trends than the other ASEAN countries, while imports from Indonesia and Viet Nam also show modest increases.

Figure 1.19. US goods imports by partner, 2018-20

Year-on-year growth, nominal 3-month moving average, percentage

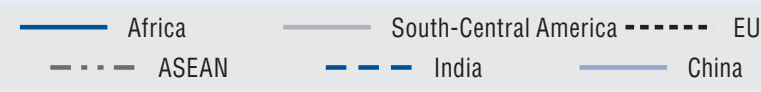

Exports

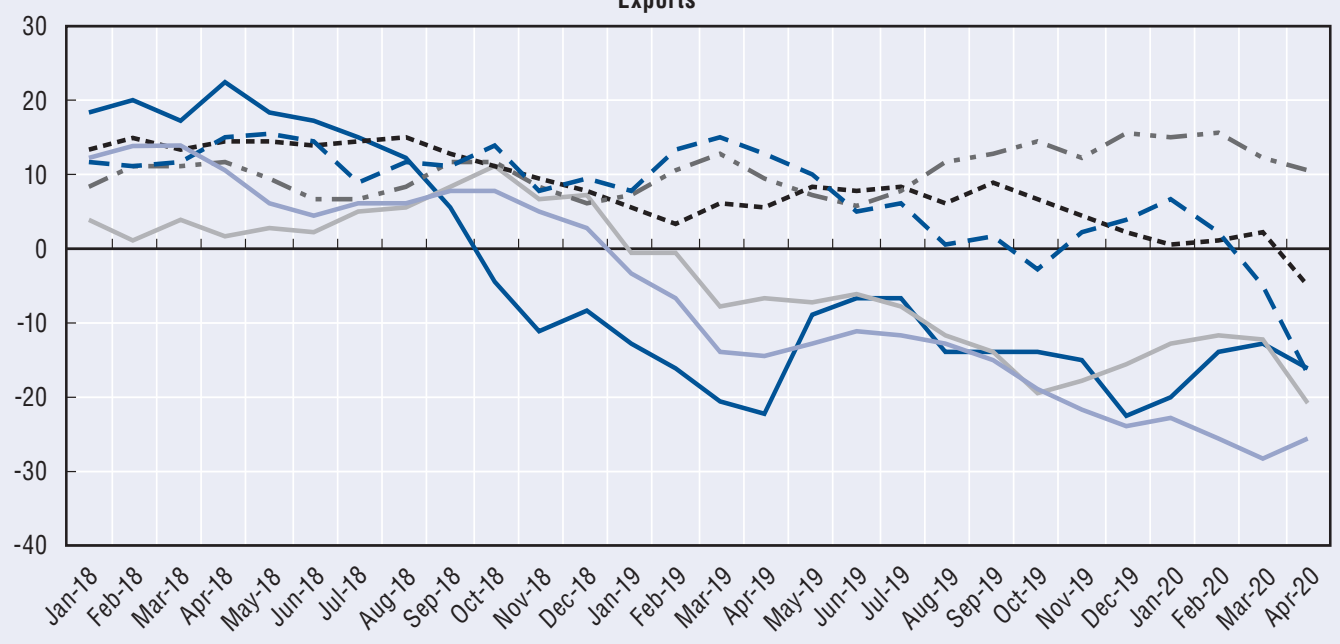

Note: Africa, EU and South-Central America aggregations were provided by the source. Latest data are as of April 2020.

Source: OECD Development Centre based on US Census Bureau.

StatLink intst https://doi.org/10.1787/888934160855

\section{India}

India has become the new epicentre of COVID-19 in Asia and the government is struggling to halt a persistent rise in cases. The country recorded its first COVID-19 infection at the end of January. The number of cases increased relatively moderately in the next two months and the situation was fairly stable. Confirmation of infections began to increase faster in April, with the case fatality rate following an almost identical trend. Travel and visa restrictions covering a number of countries were imposed in early March, and staggered school closures were imposed around the same time. The travel advisory was reinforced around the third week of March. Subsequently, several districts and Union Territories were placed under strict movement controls. In the second week of April, the containment measures were extended, though areas where infections had subsided were given some leeway. New guidelines were issued for e-commerce deliveries and distribution companies to ensure availability of supplies and reinvigorate trade. Manufacturing was allowed to resume partially in selected locales, like economic and export processing 
zones, IT-enabled services and agriculture in some areas. Despite the interventions, cases continued to rise steadily. The limitations on movement placed an enormous burden on many people, particularly those living at the fringes of the society and migrants, and in a country with a large informal sector the economic toll is mounting (Box 1.9). Facing these myriad challenges, the government decided to ease the containment measures in early June under a localised approach, applying stricter rules to areas where the case-load is high. Cases continued to rise sharply under the new rules.

GDP growth in FY 2019 eased to 4.2\% from 6.1\% in the previous fiscal year, the third straight year that output growth has slowed in Emerging Asia's second-largest economy. Government spending and private consumption did much of the heavy lifting on the demand side as investment and exports slackened. Supply-side data reveal marked improvement in agriculture output. Services growth cooled though the sector remains the biggest economic contributor. Growth in the industry sector moderated owing to the slowdown in manufacturing and utilities.

India's economy is forecast to contract in FY 2020 (ending March 2021). The contraction of about $3.7 \%$ will snap a streak of positive growth that lasted more than 40 years. Assuming that the banking sector's health holds up throughout the recovery process, the economy should record a more robust expansion in FY 2021. Economic performance in the first two quarters of the new fiscal year is on track to weaken further in light of the COVID-19 measures undertaken between mid-March and May and the continued rise in confirmed cases. Bank lending growth stayed on a downward trajectory in recent months and it is likely to slow further. India entered the year with its banking sector still saddled by a high amount of non-performing assets, and recent events could heighten risk aversion even more. Incidentally, the central bank has allowed financial institutions to defer reimbursement of term loan instalments due to the situation. Separately, business and consumer confidence indices underline growing economic pessimism as firms' and households' financial positions deteriorate (Figure 1.20). A credit-rating downgrade (Moody's, 2020) weakens market confidence and lessens the public sector's elbow room. The value of goods exports declined sharply in April-May, while tourist arrivals between January and March 2020 also plummeted. Reviving areas that were recently devastated by a typhoon will add to the fiscal strain, as will the economic losses and social impact of the calamity. A package of support rolled out by the public sector, including the central bank, covers subsistence spending of vulnerable and financially challenged segments, small and medium enterprises, non-bank financial institutions and agricultural stakeholders. ${ }^{3}$ 
Figure 1.20. Confidence indices, goods exports and tourist arrivals, India, 2018-20

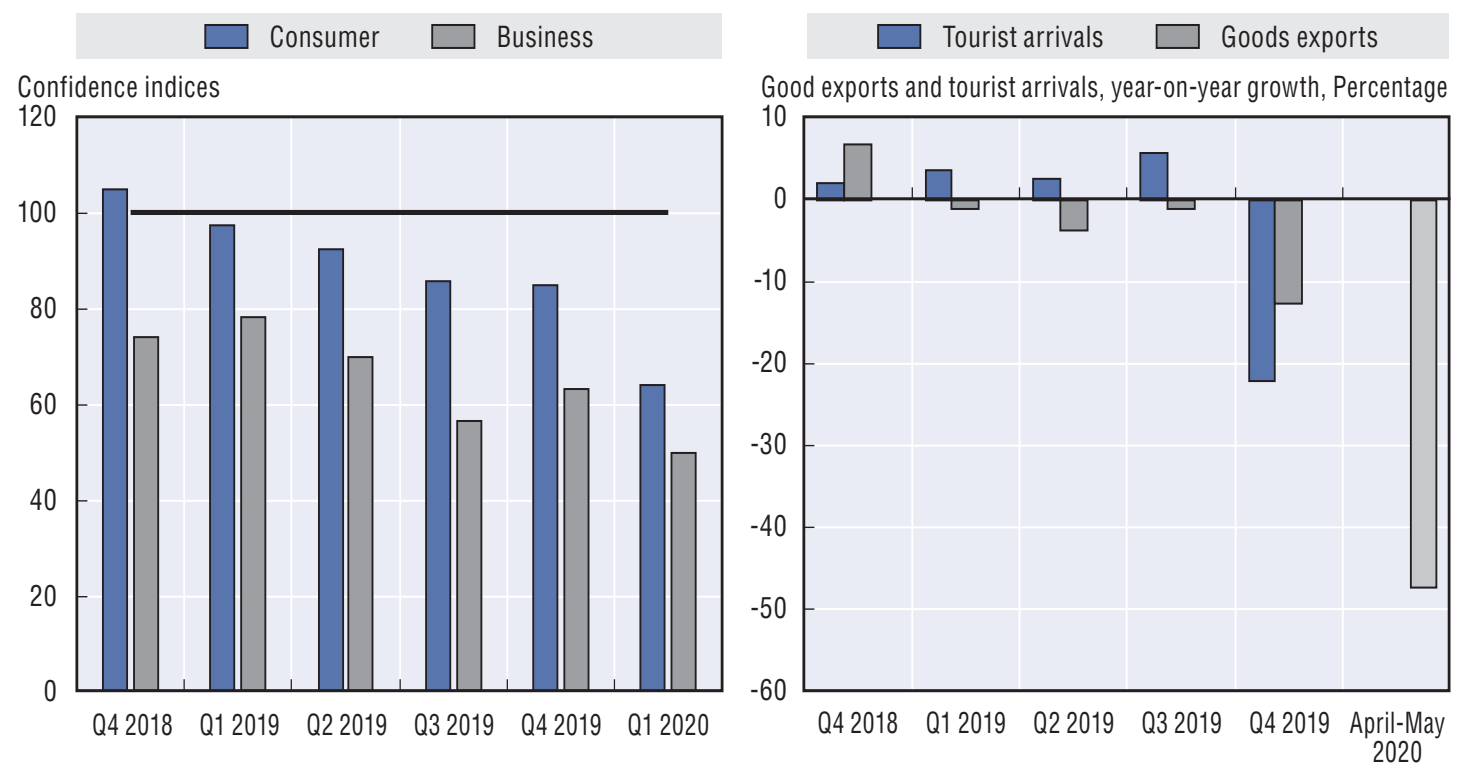

Note: The data follow fiscal years (ending March). Tourist arrivals data are as of March 2020 while exports are as of May 2020. The confidence indices are adjusted to set 100 as neutral confidence point. The data are as of 26 June 2020. Source: OECD Development Centre based on CEIC and national sources.

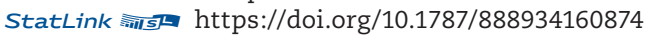

\section{Box 1.9. The economic implications of lockdown in Emerging Asia}

Looking at the appropriate length of a lockdown, a recent study found that suppression is unlikely to produce the desired results if the restrictions are abandoned too soon i.e. ending the policy in under six weeks - and that the optimal duration of the policy depends on how effective it is in reducing the rate of virus transmission (Scherbina, 2020). A combination of physical distancing, self-isolation and closures of schools and universities may need to be maintained until a vaccine becomes available (Ferguson et al., 2020). Looking at the United States, a report using the Susceptible-Infected-Recovered (SIR) model approach warns that once mitigation efforts are relaxed the disease will restart its rapid progression and reach its peak rate of infections approximately 15 months from now (Atkeson, 2020). The scope of the lockdown, its duration and the underlying economic and health costs also depend on measures that improve the capacity of the health system to cope with the epidemic and the strength of countries' economic fundamentals (Ornelas, 2020).

At the same time, the direct and indirect economic costs of combatting the disease through lockdowns are significant (Table 1.5). In a trade-off between restrictions and economic activity, policy makers must tackle challenges to public health while mitigating the economic impacts of COVID-19. A recent analysis warns that the economic and health costs will be much higher for developing economies than for advanced ones. Thus, largescale lockdowns may not be economically or socially sustainable over long periods. 
Box 1.9. The economic implications of lockdown in Emerging Asia (cont.) Table 1.5. Length and estimated impact of lockdown measures in Emerging Asia

\begin{tabular}{lll}
\hline Country & \multicolumn{1}{c}{ Length of lockdown } & \multicolumn{1}{c}{ Estimated impact } \\
\hline India & 69 days (24 March to 1 June) & $\begin{array}{l}\text { Over USD 4.5 billion per day of lockdown and approximately } \\
\text { USD 100 billion for the entire lockdown period }\end{array}$ \\
Malaysia & 47 days (18 March to 4 May) & MYR 2.4 billion lost for every day of business suspension \\
Philippines & 76 days (17 March to 1 June) & $\begin{array}{l}\text { Approximately PHP 1.1 trillion, or the equivalent of } 5.56 \% \text { of the GDP } \\
\text { Approximately SGD 10 billion (USD 7 billion) in lost output, or the }\end{array}$ \\
Singapore & 56 days (7 April to 2 June) & \begin{tabular}{l} 
equivalent of about 2\% of GDP \\
\hline
\end{tabular}
\end{tabular}

Note: The start of the lockdown period is considered to be the date when the majority of non-essential businesses were ordered to close. The end of the lockdown is considered to be the date when restrictions started to be relaxed/removed for the first time and for a significant number of activities. The term "lockdown" may have had different designations across countries.

Source: OECD Development Centre based on national sources; University of Oxford, Coronavirus Government Response Tracker (database) (accessed on 28 June); Prime Minister's Office of Malaysia (2020a); NEDA (2020); and Bloomberg Quint (2020).

Resumption of economic activities should be conducted cautiously, with prevention and control measures remaining in place. Moreover, the effectiveness of lockdown measures will differ depending on other policies enacted simultaneously. More specifically, lockdown is found to be more effective when it coincides with appropriate macroeconomic policies, namely loosening the monetary stance and providing an abundant social safety net (Guerrieri et al., 2020). Indeed, many Emerging Asian countries eased their monetary policy stances by reducing policy rates and/or lowering the reserve requirements applicable to the banking sector. Monetary measures were accompanied by ample stimulus packages aimed at easing the financial burden on firms while preserving households' income. The announced packages include financial support to vulnerable populations (Indonesia, the Philippines and Singapore), and reduction of required pension-fund contributions (Malaysia), among other measures.

Another major difficulty in adopting the right policy response to COVID-19 is that it has engendered an unprecedented economic crisis with shocks to both supply and demand. This sets it apart from the global financial crisis of 2007-08, which was considered a demand shock. In today's crisis, workers and businesses are prevented from continuing their activities, affecting supply, while lockdown measures depress aggregate demand by reducing and changing consumption activities. Since traditional policy prescriptions for demand and supply shocks are completely different, COVID-19 presents a new challenge in thinking about the policy implications of a lockdown.

While the optimal duration and scope of lockdowns remain open issues, lockdowns must be combined with the right policies to ensure their effectiveness both in preventing a resurgence of viral transmission and in mitigating the unprecedented economic impacts that they bring. The economic implications of lockdown should be discussed in the specific context of Emerging Asia.

Source: Tanaka, K. and M. Pezzini (2020), The Economic Implications of Lockdown in Emerging Asia, OECD Development Matters blog post, https://oecd-development-matters.org/2020/04/15/the-economic-implications-of-lockdownin-emerging-asia/. 


\section{Governments have fiscal leeway but limited space calls for efficient spending}

Governments in Emerging Asia have taken drastic measures to finance pandemicrelated spending. Following nominal data compiled by ADB (2020), the fiscal outlays of ASEAN-5, Singapore, China and India for health services, tax adjustments, subsidies and income support (excluding credit guarantees, money market intervention, direct lending and those with no breakdown) range from less than $0.1 \%$ to about $8.6 \%$ of GDP (Figure 1.21). Financing these obligations involves borrowing from multilateral development banks and the market. Certain central banks also bought national government debt securities. In addition, budgetary items have been reallocated to pandemic-related initiatives. Contributions from multilateral agencies, other governments, private firms and philanthropic organisations have helped to deepen public coffers. In this context, improvements in the credit ratings of a number of countries prior to this shock has helped reduce the cost of capital raising. Indonesia, the Philippines and Viet Nam for instance, have seen their credit ratings adjusted upwards at least once in the last five years. ${ }^{5}$ Regarding macroeconomic conditions, the low interest-rate environment augurs well for sovereign borrowers.

Figure 1.21. Total amount of fiscal packages and estimated impact on the fiscal balance of selected Emerging Asian economies

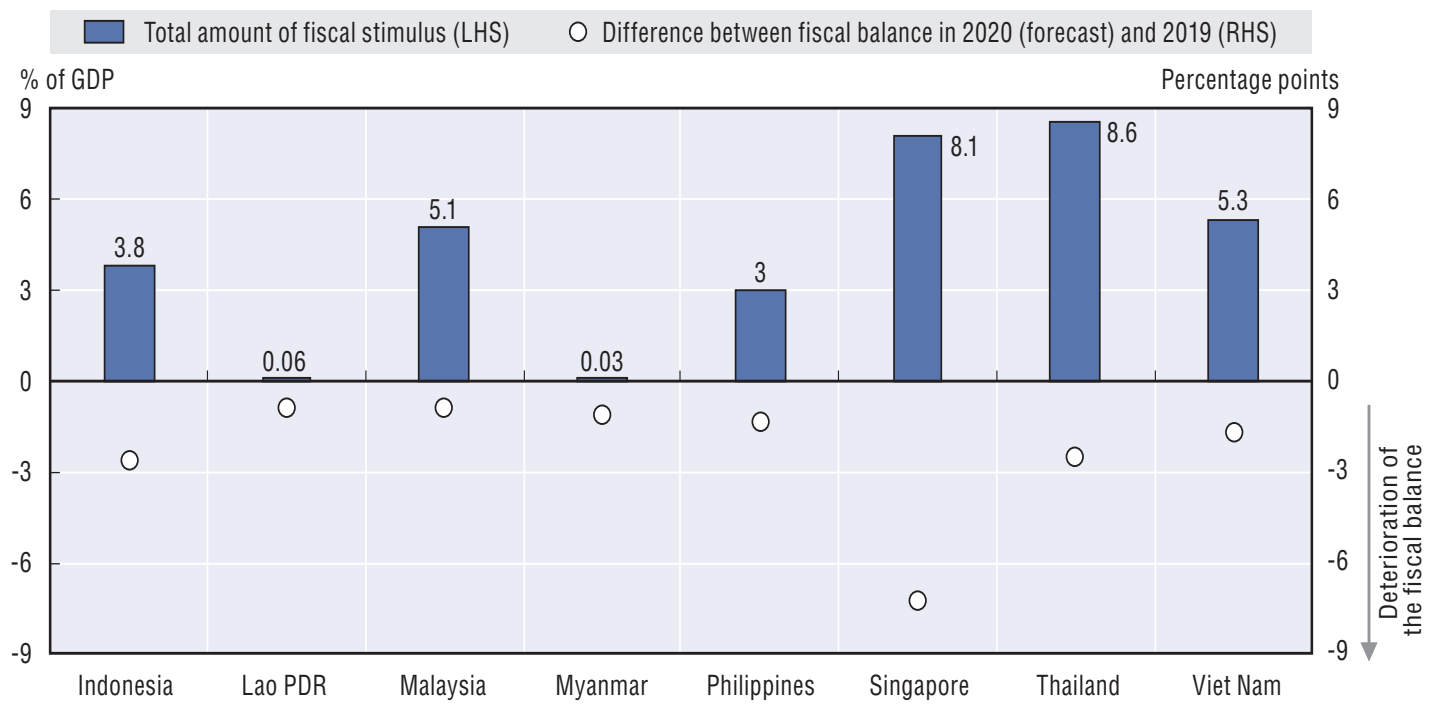

Note: The cut-off date for the fiscal stimulus data is 15 June 2020. Data refer to the general government.

Source: OECD Development Centre based on: ADB (2020), ADB COVID-19 Policy Database; IMF (2020b), World Economic Outlook database, April 2020; and the World Bank national accounts dataset.

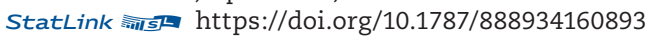

Emerging Asian countries have implemented various fiscal tools to cope with the economic impact of the pandemic. As outlined in Annex 1.1, fiscal support packages were provided in the form of tax relief and benefits to stabilise income and consumption, while progressive taxation and unemployment benefits were introduced to ease conditions for businesses and workers.

In Thailand, the first economic response was a fiscal package of THB 1.9 trillion (Thai baht) to finance income-loss compensation and public health improvements and to cover assistance for 3 million workers outside the government social security system, including businesses and individuals affected by COVID-19. Greater access to loans from specialised financial institutions was also provided.

Singapore unveiled four tranches of support to aid households, lower-income individuals and the unemployed. The first package, approved in February, was estimated 
at USD 4.4 billion for workers and businesses through co-funding of business costs and tax relief (Unity Budget). In March, Singapore unveiled another plan worth USD 33 billion to assist hard-hit sectors like food services, aviation, tourism and self-employed individuals (Resilience Budget). Another tranche amounting to USD 23.2 billion was released in May to provide additional support to workers and businesses (Fortitude Budget).

In Malaysia, the main thrust of the economic packages was to enhance cash flow for households and businesses. The first, worth USD 4.6 billion, was announced in February and sought to alleviate the pandemic's immediate impact on the tourism industry and other hard-hit sectors. Incentives for industry included tax deductions, deferral on the payment of monthly income tax instalments and exemption of the hospitality industry from service tax on the provision of accommodation and related services for six months commencing March 2020 (Prime Minister's Office of Malaysia, 2020b).

In Myanmar, hard-hit sectors like hotels, tourism companies and SMEs are receiving an allocation amounting to MMK 100 billion (Myanmar kyat). To assist companies affected by the slowdown in business activity, the government offered assistance through loans with an interest rate of $1 \%$ and a grace period of one year to help employers pay salaries. Tax payment deferrals were extended to ease the financial position of businesses and workers. The government is also providing a $40 \%$ social security support to 1.3 million workers who were dismissed due to COVID-19.

In contrast, Brunei Darussalam, Cambodia and Lao PDR have shown limited flexibility in monetary and fiscal support. In particular, direct income transfers in Lao PDR are marginally low compared to all Emerging Asian countries, but other measures are provided in the form of tax incentives, including tariff exemptions and relevant fees of imported goods to be used in the containment of COVID-19. In Cambodia and Brunei Darussalam, government responses have concentrated on indirect income and non-cash incentives. The total stimulus effect of Cambodia's response is estimated to stabilise the economy by $8.7 \%$, and Brunei Darussalam's by $2.6 \%$.

Across Emerging Asia, efficient spending is needed because low domestic and global economic growth mean less revenue intake. Central government data between March and May reveal that, with the exception of Cambodia, fiscal revenue shrank in all Emerging Asian economies where data are available, and by a good margin, between $7.9 \%$ and $38 \%{ }^{6}$ Deferment of tax filing and lower enterprise sales are slowing collections. The stress on national coffers will extend at least until next year, when employment and corporate income taxes for this year will be paid. India's sovereign credit rating, for instance, has been downgraded by Moody's owing to limited progress in structural reforms, which amplifies the pandemic's impact on economic stability (Moody's, 2020). For Brunei Darussalam, Indonesia and Malaysia, subdued global oil prices present further difficulties for boosting fiscal resources, even though prices have recovered since endApril. Expenditure momentum varies across countries. Available data from March 2020 onwards suggest that momentum remains contained in China and Indonesia, is just picking up in India and Malaysia, and is brisk in Cambodia, the Philippines and Thailand.

In terms of debt, Emerging Asian economies have some fiscal leeway. Governments have been largely measured in managing their debt in the last few years (Figure 1.22). Nonetheless, the sheer spending requirements induced by COVID-19 to maintain social order and help the real economy regain its pre-pandemic health will present a challenging fiscal test. It pays for governments to continue to prioritise job retention and social protection in the recovery phase in order to maintain social stability. Stimulus spending per se can only take root once production lines have been fully restored. Accordingly, maximising the outcome of expenditures, including assistance from external parties, is a crucial challenge. 
Figure 1.22. General government gross debt

Percentage of GDP

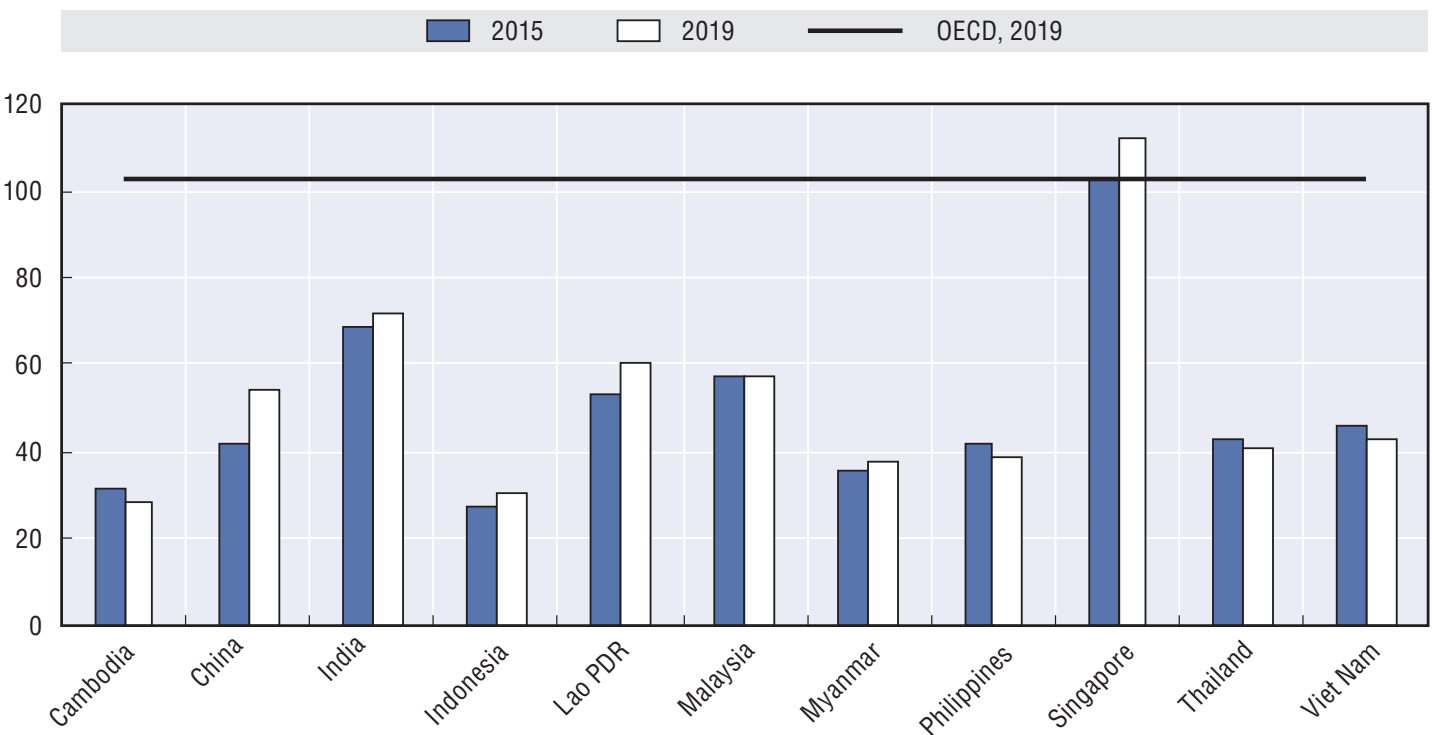

Note: OECD average is calculated using the country-level gross debt ratios in the IMF Fiscal Monitor database and the GDP data in the IMF World Economic Outlook database.

Source: OECD Development Centre; IMF (2020c), Fiscal Monitor Database; and IMF (2020b), World Economic Outlook Database.

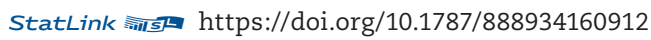

Stretching fiscal capacity in response to COVID-19, including by expanding emergency funding across levels of government early in the year, could mean more difficulties ahead for Emerging Asia. The region is highly susceptible to natural disasters such as storms and flooding, particularly in the second half of the year. India and the Philippines have already dealt with destructive storms in May. When people are displaced by natural disasters, substantial financial allocation is needed for relocation, immediate response and rebuilding. Similarly, the drought in the Mekong region presents a persistent risk that could require government funding.

With these difficulties compounded by COVID-19, many governments in Emerging Asia are hard-pressed to manage the increase in their initially planned fiscal deficit ratios. The commitment of the regions' major stakeholders to further strengthen regional financial safety nets will be material in maintaining market trust.

\section{The sizeable cost of COVID-19 will test fiscal management}

The COVID-19 pandemic and recovery programmes will push the fiscal limits of many economies into uncharted waters. Baseline public debt levels in a number of advanced economies were already at historic highs prior to the pandemic owing to different rounds of quantitative easing. Debt accumulation will now have a much broader base as emerging markets join in the massive fiscal expansion to keep social discipline intact and reinvigorate their economies. It is worth noting that the rising debt pile is matched by interest rates that are racing to the bottom and negative-yielding bonds that have substantially grown in volume (Borio, 2019). It thus becomes relevant to assess the implications of these developments for future tax levels to avoid the debt trap. 
The extensive involvement of central banks in capital-raising activity by national governments has been a key feature of the response of the United States and European Union at times of economic difficulty. The exercise called debt monetisation or moneyfinanced fiscal expansion (printing money to buy national government debt) has continued, even after the worst phase of the pandemic has passed, as a measure to push back against the liquidity trap.

In Emerging Asian economies, government debt is typically marketed to nongovernment entities, with the exception of Myanmar, whose secondary market liquidity is still developing. The share of central government debt in central banks' total assets in Emerging Asia is far lower than in advanced economies (Figure 1.23). Inflation is a key consideration in undertaking this policy option.

Figure 1.23. Central bank claims on central government, 2019

Share in central banks' gross claims, percentage

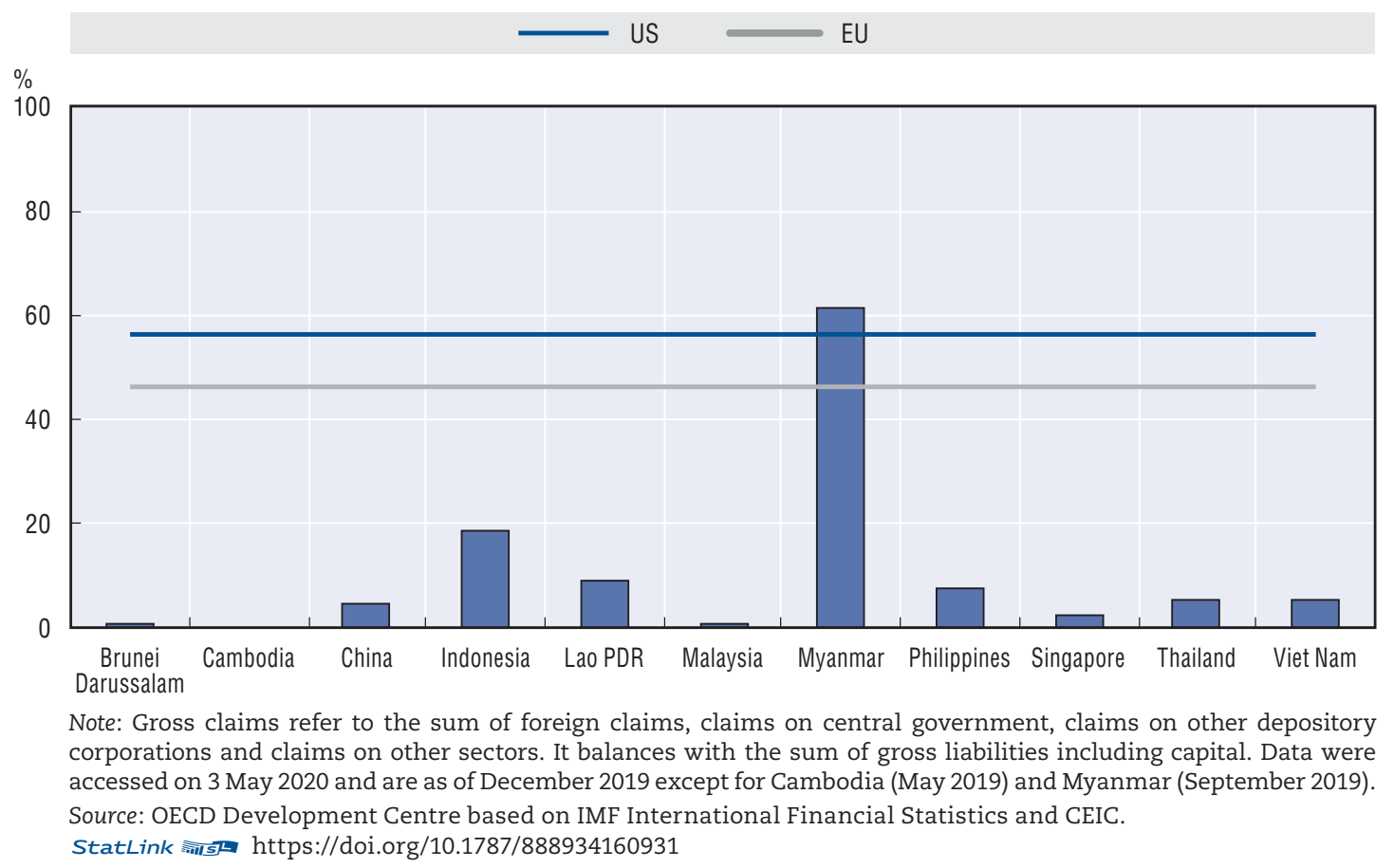

Recent events have prompted some Emerging Asian economies to shift strategies. The central banks of Indonesia and the Philippines, for instance, have been granted the authority to support government financing needs directly (Bangko Sentral ng Pilipinas, 2020b; Bank Indonesia, 2020). The Philippine central bank has entered into a 3-month repo agreement with the treasury, while the Bank of Indonesia purchased government Islamic bonds during the primary market auction in the last week of April. Unlike the advanced economies, however, the Philippines and Indonesia have signalled that this will be a remedial measure

This brings to light the notion of helicopter money. The idea can be traced back to Friedman (1969) and in brief, helicopter money refers to the policy of flooding the system with money at no cost. Central banks buying government debt at zero interest rate, and then repudiating the debt incurred, is one way to administer helicopter money. However, such monetary and fiscal policy co-ordination tends to breach the principle of central 
bank independence and could compromise fiscal discipline in the long run. It could also substantially weaken the central bank's capital base and instigate inflationary pressures.

Another consideration in sharply increasing government borrowing from the market is that private borrowers will be crowded out. It could also result in the divergence of market interest rates from policy rates and could be burdensome for government finances in the future. Along these lines, the EU's coronabonds proposal raises the question of whether economies in Asia could undertake a similar project, to go hand-in-hand with regional safety nets like the Chiang Mai Initiative Multilateralisation.

It has been argued that the mutualisation of fiscal risk espoused in the idea of the coronabond is somewhat similar to the European community bond under the community loan mechanism created in the 1970s (Horn, Meyer and Trebesch, 2020). The community loan mechanism complemented the existing European Medium-Term Financial Assistance Facility before the two were eventually merged to form the EU Balance-ofPayments Facility. A key feature of the community bonds is provisions on guarantees supported by the EU budget and direct country quotas.

\section{Monetary support goes into overdrive}

The extent of monetary support in major economies effectively ushers in a return to the low-interest rate, high-liquidity environment experienced during the quantitative easing period. Central banks in the United States, European Union, Japan and the United Kingdom have further loosened their policy stances to combat the adverse effects of the health crisis. The United States brought its policy rate back to its historic lowest point as the other major central banks left theirs at close to zero, if not negative. They have also relaunched massive asset-purchase programmes.

Emerging Asian economies proved to be just as inclined to increase monetary accommodation. In a continuation of the policy mix of the previous year, reserve requirement ratios for banks have been adjusted to augment the changes in policy rates to facilitate easier liquidity conditions. The central banks of China, India, Indonesia, Malaysia, Myanmar, the Philippines and Thailand have lowered their interest-rate instruments by 30 to 300 basis points (bps) since the end of 2019 (Figure 1.24). The policy rate in Thailand is at its historic low since the current policy rate series began in May 2000. Similarly, the policy rate in the Philippines is at its lowest point since the interest rate corridor was adopted in July 2016.

New rounds of easing to reserve requirement ratios (RRR) have been implemented since January 2020. Indonesia's statutory RRR dropped to its lowest level since the start of the data series in January 1997. A sizeable cut in RRR in the Philippines has likewise pushed the current rate to a new trough since September 2000 and is expected to be cut by another 200 bps before the end of the year (Bangko Sentral ng Pilipinas, 2020c). The central banks of China and India adopted similar measures. Other financial interventions implemented in the region include deferral of loan payments, conversion of short-term credit into long-term, liquidity injections via open market operations, support for bond issuances, targeted lending and relaxation of mandated macroprudential thresholds, among others. ${ }^{\text {? }}$ 
Figure 1.24. Monetary policy actions in selected Emerging Asian economies, 2020 Basis points
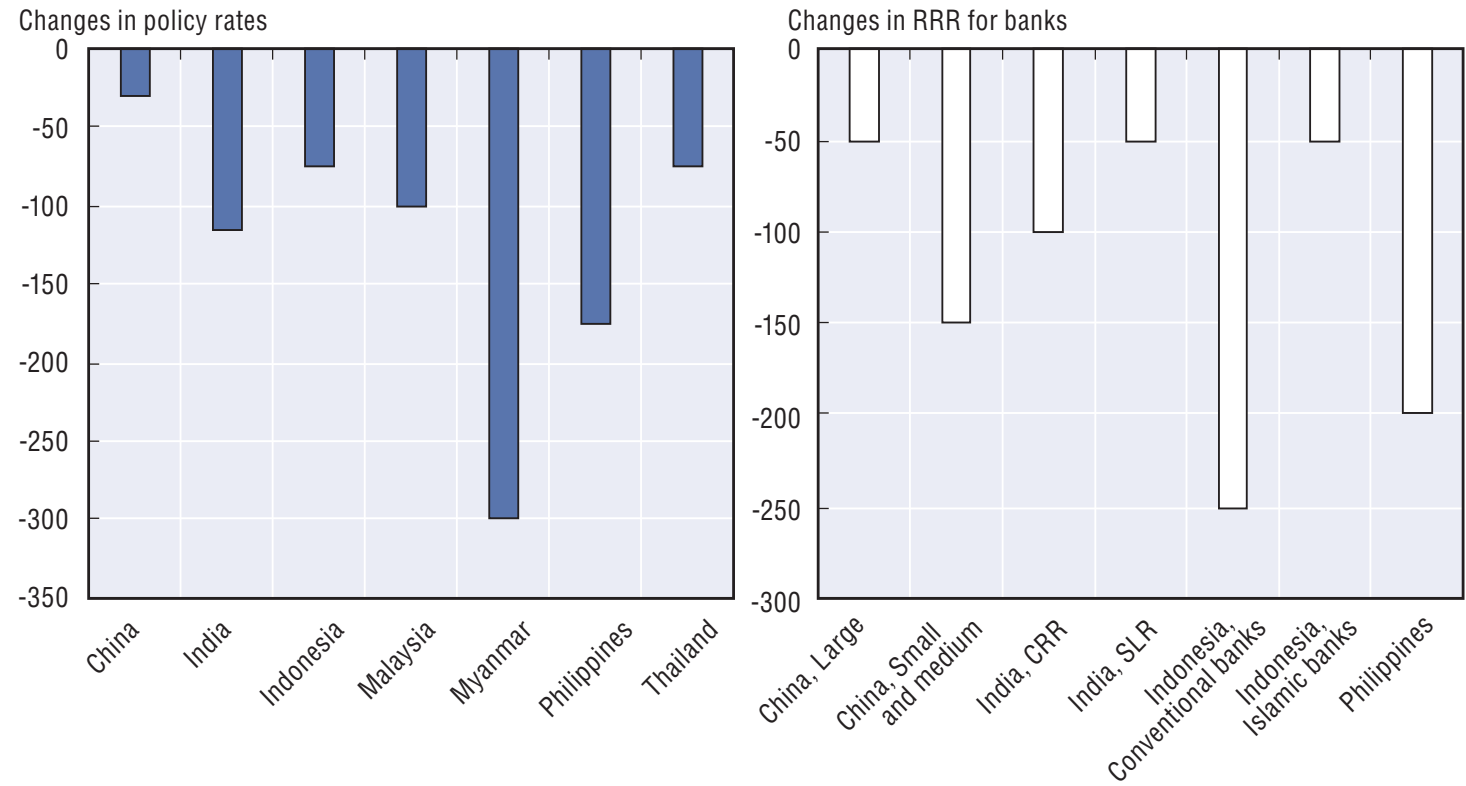

Note: For China, policy rate relates to the one-year loan prime rate, and RRR cuts for those small and medium banks in China that specialise in lending to priority sectors are even larger. For India, SLR means statutory liquidity ratio and CRR means cash reserve ratio. For Indonesia, the first local currency RRR cut was announced in December 2019, effective January 2020. In March 2020, Indonesia lowered the foreign currency RRR by 400 bps and the RRR of banks engaged in import and export financing by 50 bps. For the Philippines, RRR covers commercial banks' local currency deposits. The data are from 1 January 2020 to 26 June 2020.

Source: OECD Development Centre calculations based on data from CEIC and national sources.

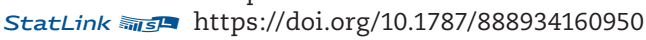

Monetary tools aside, central banks in Emerging Asia have ramped up procurement of national government debt to finance fiscal expansion. Generally, central banks obtain government bonds through transactions in the secondary market. However, given the circumstances, Indonesia and the Philippines have granted their respective central banks the authority to purchase government bonds in the primary market for a specific period.

\section{Risk remains elevated in financial markets}

Corporate earnings are under heavy fire as the real sector reels from the impact of COVID-19 and measures to contain its spread. The grim expectations on corporate performance have swept the equities markets across Emerging Asia and in other regions, pushing the benchmark indices to multi-year lows in the first three months of the year (Figure 1.25). Yet hopes brought by the partial re-opening of economies have pushed equity prices higher to erase some of their losses after the multi-year lows observed in MarchApril 2020.

The bond markets, in contrast, have been somewhat calmer. Yields have moved in accordance with monetary stances, and spreads vis-à-vis US bonds have reversed since April 2020 (Figure 1.25). Monetary policy actions and fiscal assurances alleviated budding investor apprehension at the end of Q1 2020. Substantial lending from multilateral development banks has likewise lessened countries' inclinations to tap the market. Corporate solvencies and the extent of supplementary government borrowing from the market are two factors that could heavily influence the direction of yields moving forward. 
Figure 1.25. Changes in stock price indices and bond yield and term spreads in Emerging Asia, 2019-20

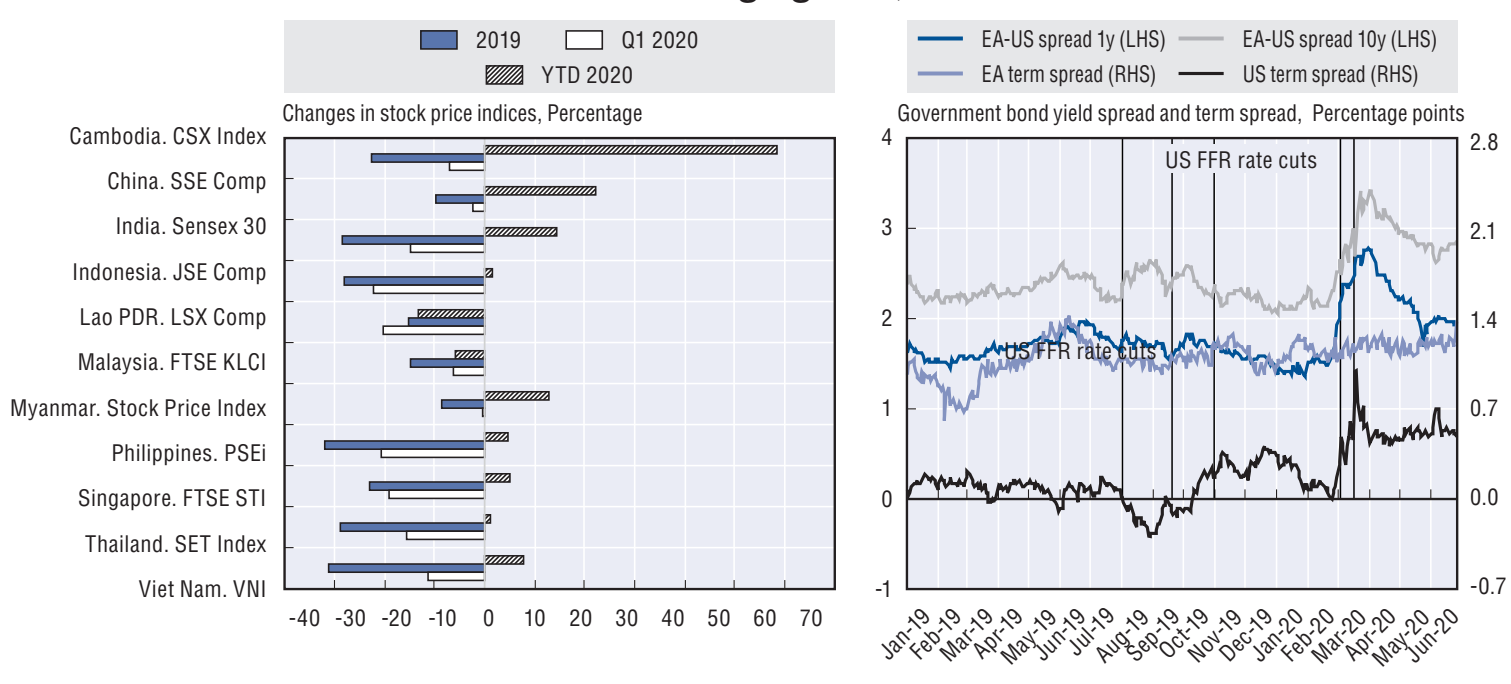

Note: For bond yields, Emerging Asia refers to the simple average of government bond yields of China, India, Indonesia, the Philippines, Singapore, Thailand and Viet Nam. Term spread pertains to the difference between 10-year and 1-year bond yields. US FFR means US Fed Funds rate. RHS means right hand scale. LHS means left hand scale. Data are as of 26 June 2020.

Source: OECD Development Centre based on Fusion Media Ltd., www.investing.com and national sources.

StatLink 解年 https://doi.org/10.1787/888934160969

Decreases in Emerging Asian stock prices were initially accelerated by large net outflows from investment funds that focus on emerging market equities. The COVID-19 pandemic, the oil price rout and a marked deterioration of the economic outlook led to sizeable portfolio outflows. Data compiled by the Institute of International Finance points to non-resident-portfolio equity outflows of USD 72 billion and debt flows of USD 25 billion in Q1 2020, with Emerging Asia ${ }^{8}$ particularly affected (IIF, 2020). By March 2020, standard stock-price valuation measures, such as the price/earnings (P/E) ratio, had fallen markedly, although trends have been on the rise since then (Figure 1.26). Significant declines were recorded in the sectors most affected by the COVID-19 lockdown and restrictions, such as industry, construction and real estate, among others (Figure 1.26). The prospect of falling earnings due to limited business operations has driven down investor demand for the stocks of firms operating in the sectors most affected by the lockdown and restrictive measures. 
Figure 1.26. Price-to-earnings (P/E) ratio for selected Emerging Asian stock markets and sectors, 2018-20

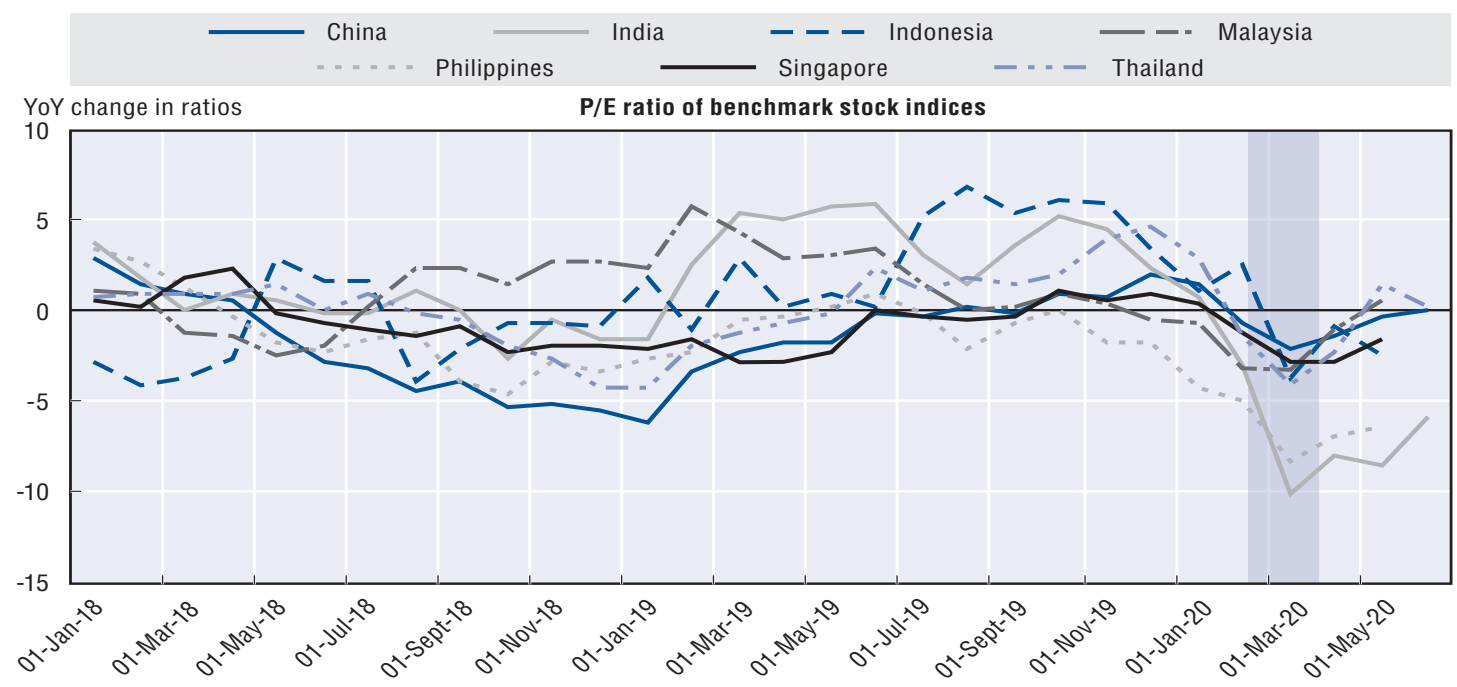

Sectoral indices with largest declines in the $\mathrm{P} / \mathrm{E}$ ratio

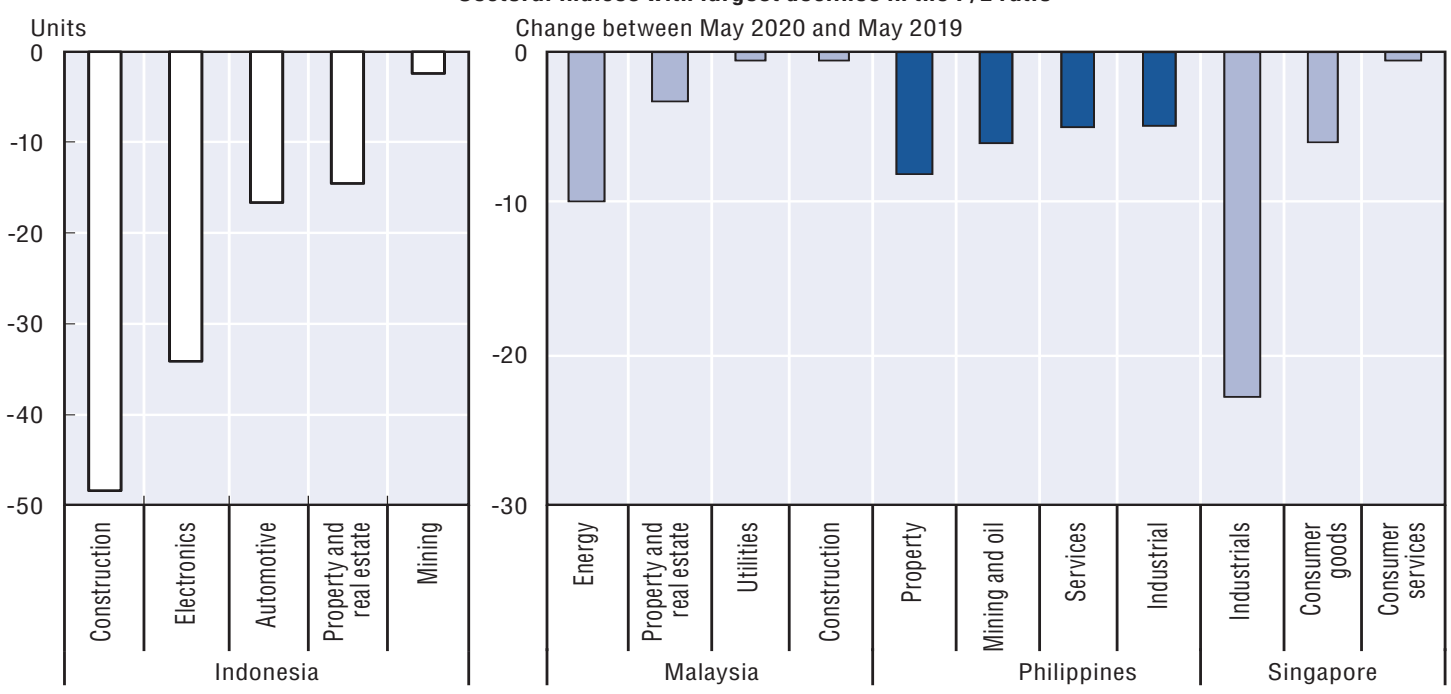

Note: The benchmark stock indices on the top figure represent the indices depicted in Figure 1.25. The RHS figure of sectoral indices displays the sectors with the largest declines in the P/E ratio between May 2020 and May 2019. Source: OECD Development Centre based on data from CEIC.

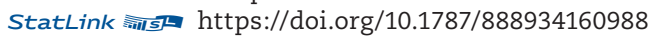

Government bond yields of Emerging Asian economies were highly volatile in the first weeks of the COVID-19 crisis (Figure 1.27). Corresponding spreads against 10-year US Treasuries increased across most Emerging Asian benchmark bonds as the crisis developed, driven by the deterioration on the health front, with the number of COVID-19 cases rising worryingly, and by the lockdown measures imposed in most countries in the region. The yield curve mostly rose in March and April 2020 across debt markets in the region (Figure 1.28).

In the weeks that followed, pressure eased and yields stabilised. Bond yields have fallen markedly in Singapore, Viet Nam and Thailand, reflecting receding risk aversion, as well as monetary policy actions and the signal for further credit market support. Credit default swap (CDS) spreads, which widened at the beginning of the crisis (Figure 1.29), also narrowed in recent months to a certain degree, mirroring the trends in the bond market. 
However, financing needs moving forward could put some upward pressure on yields in the near to long term. Higher government bond issuance could also crowd out private sector issuance. Considering the pressure on corporate solvencies, a tightening of market conditions could complicate efforts to mitigate debt defaults.

\section{Figure 1.27. Bond yield index and spreads in selected Emerging Asian economies, January-July 2020}

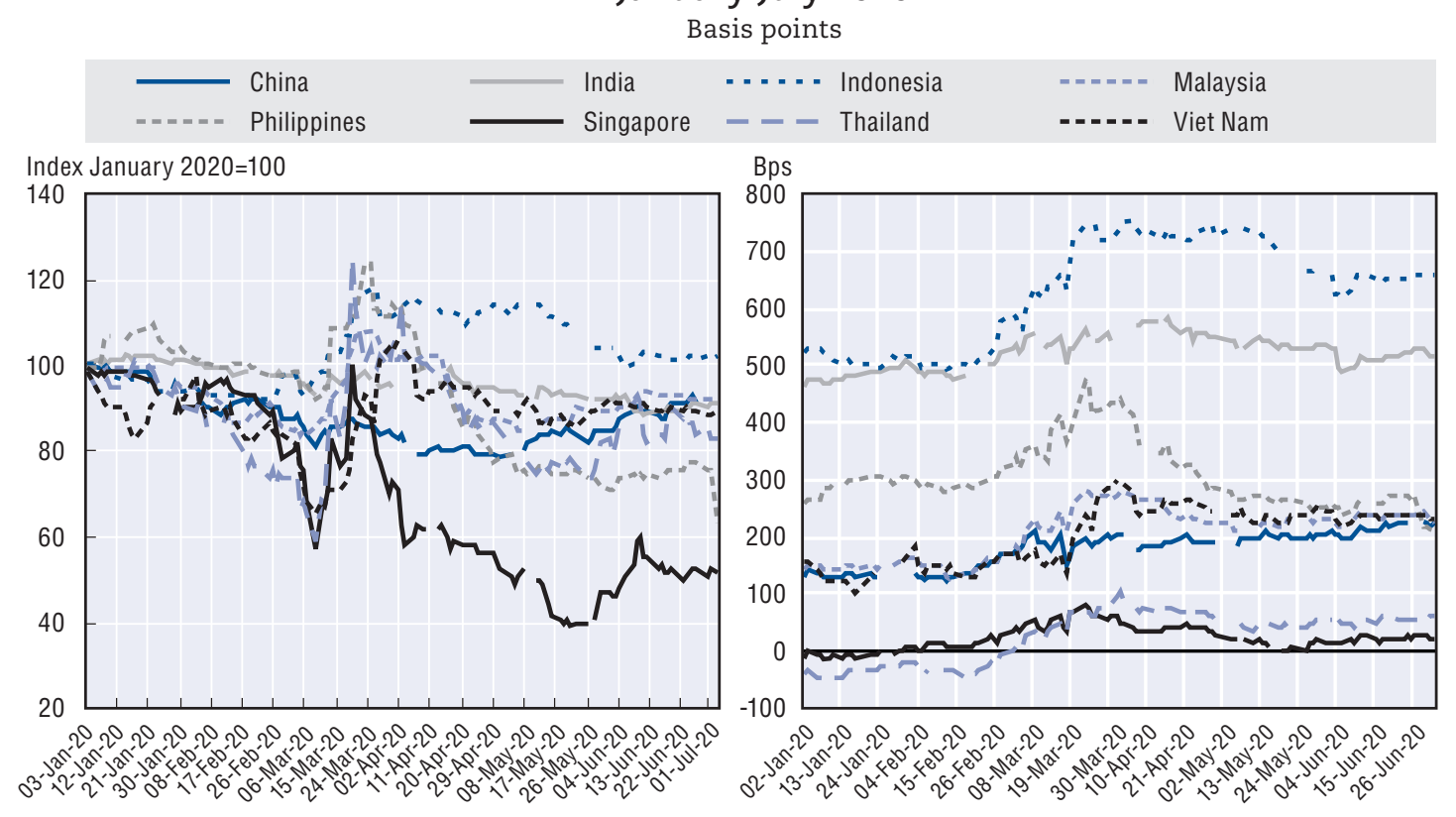

Note: Spread of 10-year sovereign bonds of selected Emerging Asian economies on 10-year US Treasuries. Source: Thomson Reuters Eikon.

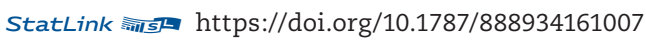

Figure 1.28. Yield curve in selected Emerging Asian economies, January-July 2020 Basis points

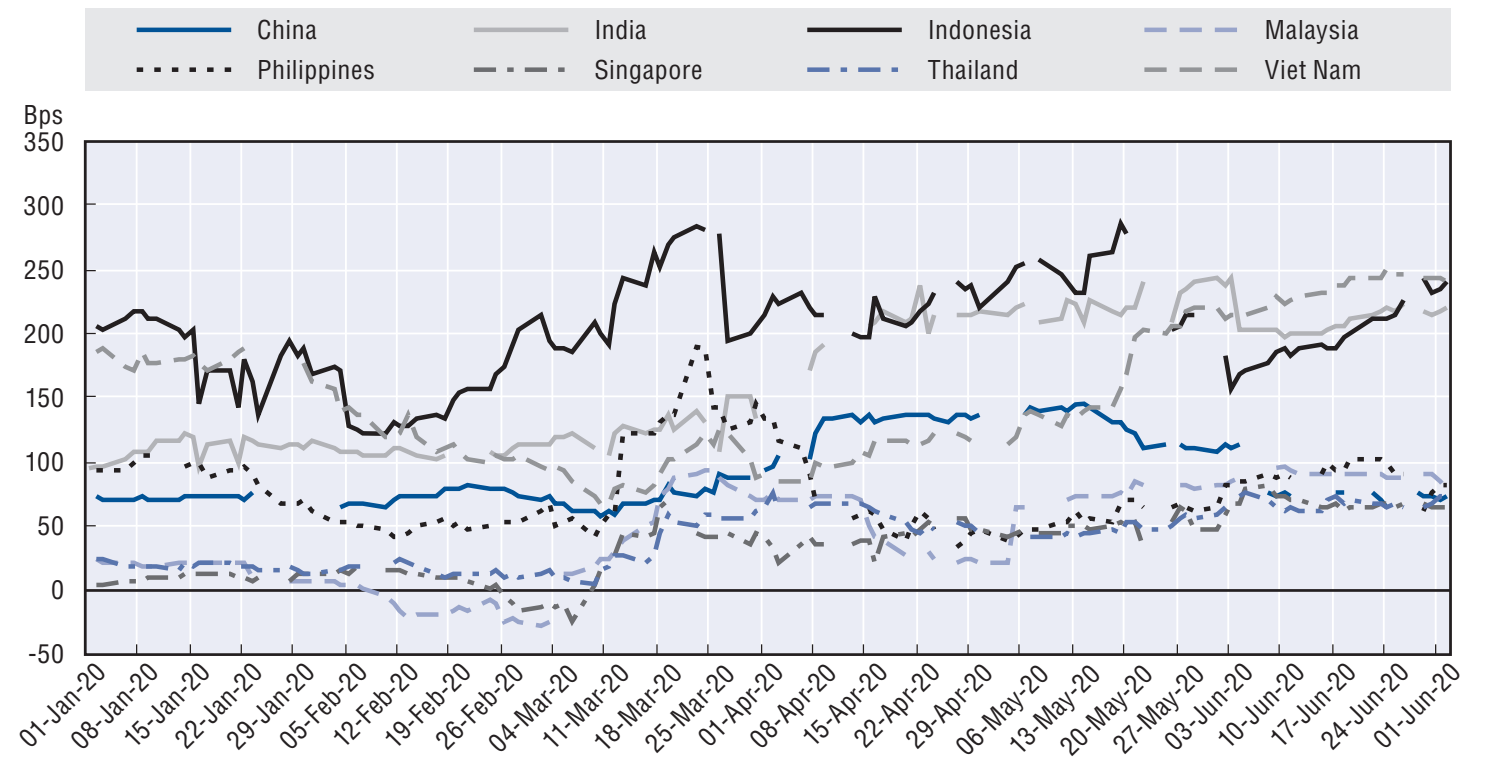

Note: The yield curve is calculated as difference between the 10-year sovereign yield and the 1-year yield.

Source: Thomson Reuters Eikon.

StatLink 部占 https://doi.org/10.1787/888934161026 
Figure 1.29. Credit default swap spreads in selected Emerging Asian economies, 2016-20

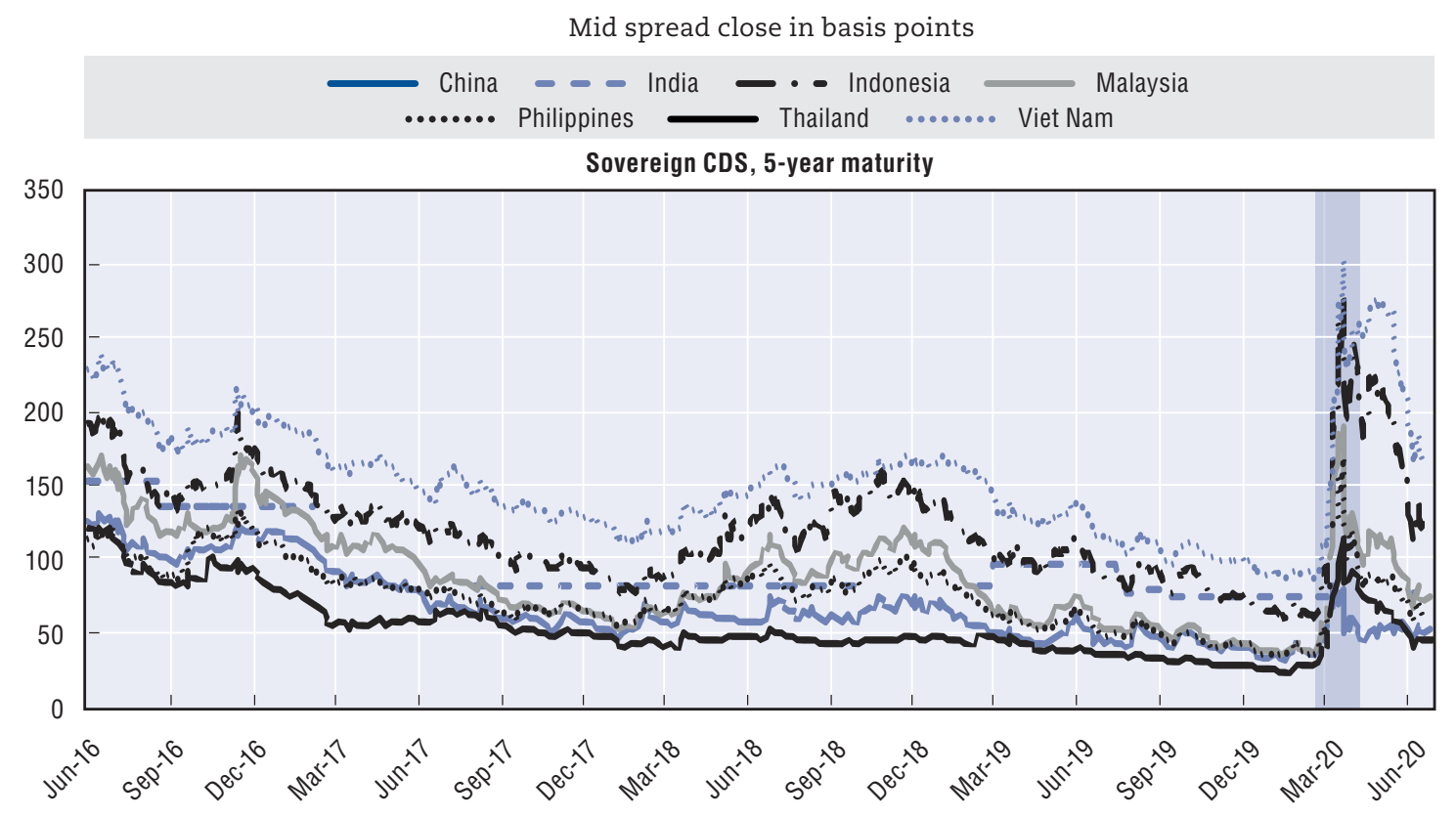

Source: Thomson Reuters Eikon.

StatLink 尚IS https://doi.org/10.1787/888934161045

\section{Box 1.10. Volatility of corporate bond defaults in China}

Defaults on onshore corporate bonds reached CNY 40.2 billion (Yuan renminbi) in February 2020, a six-fold increase from the same period the year before (Figure 1.30). Although the growth rate of defaults slowed in the following months, calming apprehensions in the onshore debt market, there are signs of uneasiness concerning financing of the offshore dollar debt issuances of Chinese companies. The concern is particularly acute for cyclical industries such as construction. Heavily indebted Chinese property developers, which account for the largest share of USD issuance in Asia, are increasingly sending signals of distress.

Figure 1.30. Developments in corporate bond defaults in China, 2018-20

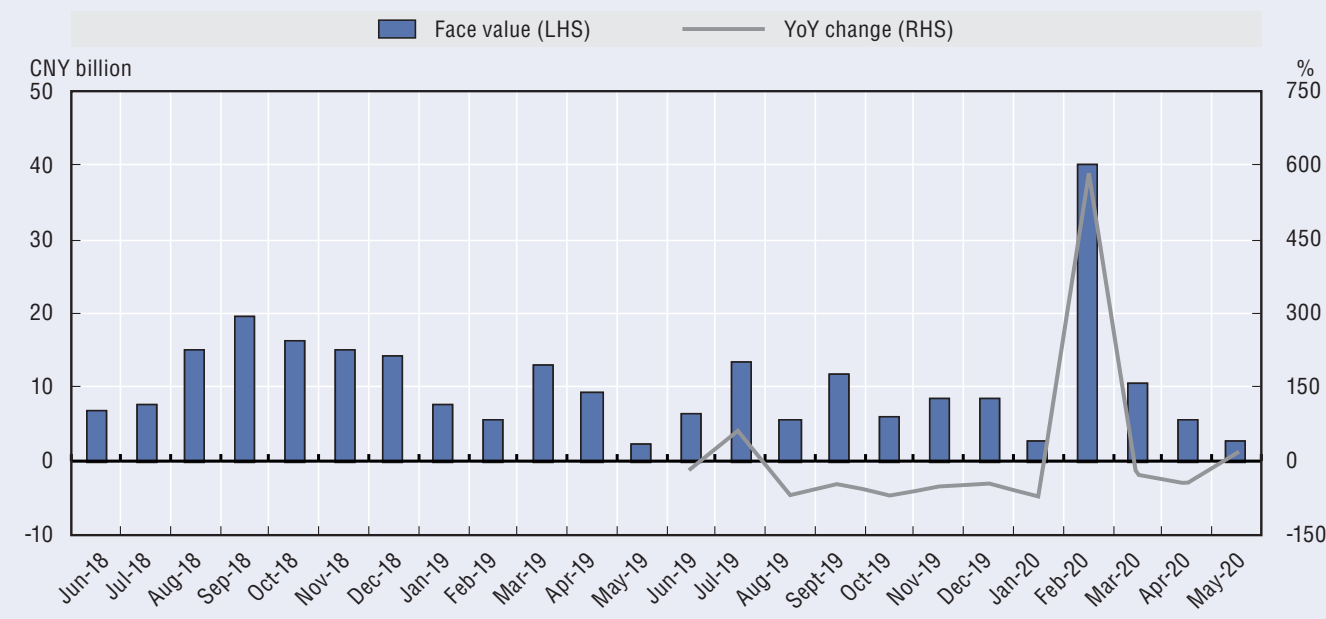

Source: OECD Development Centre based on data from CEIC.

StatLink त्माड़ https://doi.org/10.1787/888934161064 


\section{Banking sector braces for profit and solvency risks}

Banks are a particular source of concern given linkages with the heavily-impacted real sector. Managers are under continuous pressure to adjust balance sheets as central banks tighten their watch. On the upside, capital adequacy ratios (CAR) were generally sound at the end of 2019, even if limited to tier-1. To put this into perspective, Emerging Asia economies have an average of $14.5 \%$ in this metric vis-à-vis the Basel 3 accord threshold of $10.5 \%$.

However, there are country-specific concerns. For instance, the ratios of Lao PDR and Myanmar are understandably lower considering the relative level of banking sector development (Figure 1.31). And while the CAR of Myanmar's banking sector has risen since 2018, it has declined in Lao PDR by a good margin, suggesting an increase in banks' appetite for risk. The sharp rise in Lao PDR's banking returns on equity (ROE), compared to other Emerging Asian countries, lends support to this view - a strategy that will be tested given the ongoing business-cycle downturn.

India is still troubled by non-performing loans (NPL) and other assets despite the various initiatives undertaken by the central bank in recent years. Propping up the domestic bad debt market remains a big difficulty in the country and results in low asset value recovery rates. This could potentially be addressed by pursuing the longplanned public asset management company, which could work hand-in-hand with local private asset reconstruction companies and other similar institutions in the region. The marginal reduction in the NPL ratio from 2018 is a welcome development. Nonetheless, India's central bank projected that the broader gross non-performing assets of the banking sector were set to rise in 2020 (RBI, 2019), and it made the projection before the COVID-19 crisis spread. Viet Nam's banking sector has strengthened, but it is still in the process of resolving legacy assets that were pushed to the balance sheets of the public asset management company.

Figure 1.31. Capital adequacy ratio (CAR) Tier-1, return on equity (ROE) and non-performing loan (NPL) ratio levels and change in Emerging Asia, 2018-19

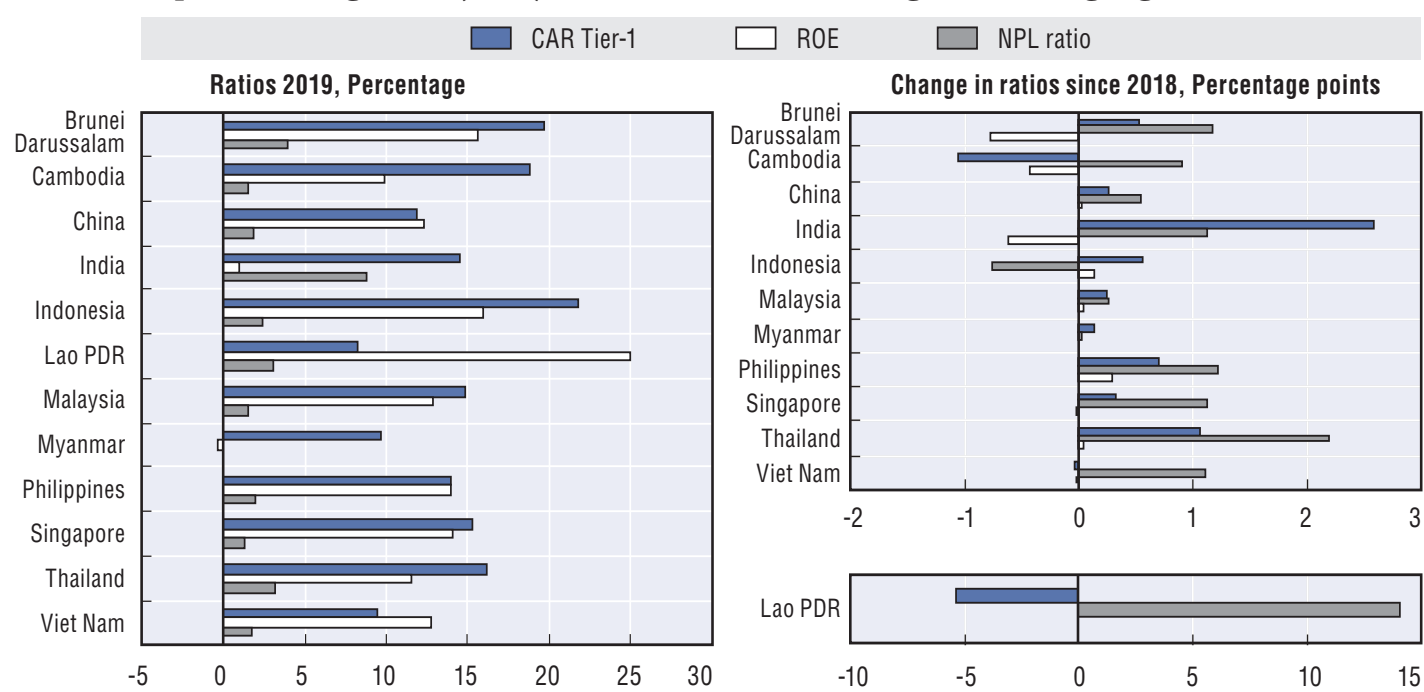

Note: The data are as of Q4 2019, except China and India (Q3 2019) and Myanmar and Viet Nam (Q2 2019). There is no NPL data for Myanmar.

Source: OECD Development Centre based on IMF and national sources.

StatLink 젶ㄴ https://doi.org/10.1787/888934161083 


\section{Capital flow and exchange-rate volatility risks are brewing}

FDI data in Q1 2020 indicate that the long-term investor view of economic prospects has remained unchanged, even though placements mostly slid slightly from the previous quarter. The annualised FDI level marginally declined from Q4 2019 in China, Indonesia, Malaysia, the Philippines, Singapore and Viet Nam, but inched upwards in Cambodia, Lao PDR and Thailand (Figure 1.32). Barring another wave of confirmed cases, the performance of many countries in Emerging Asia in handling the pandemic threat generally augurs well for keeping substantial investor interest in the region. Nevertheless, given that business conditions deteriorated more significantly in Q2 2020, net foreign placements are expected to be more conservative in Q3 2020 and possibly in the following quarter as well.

Figure 1.32. Foreign direct investment in Emerging Asian countries, 2019-20 USD billion, annualised
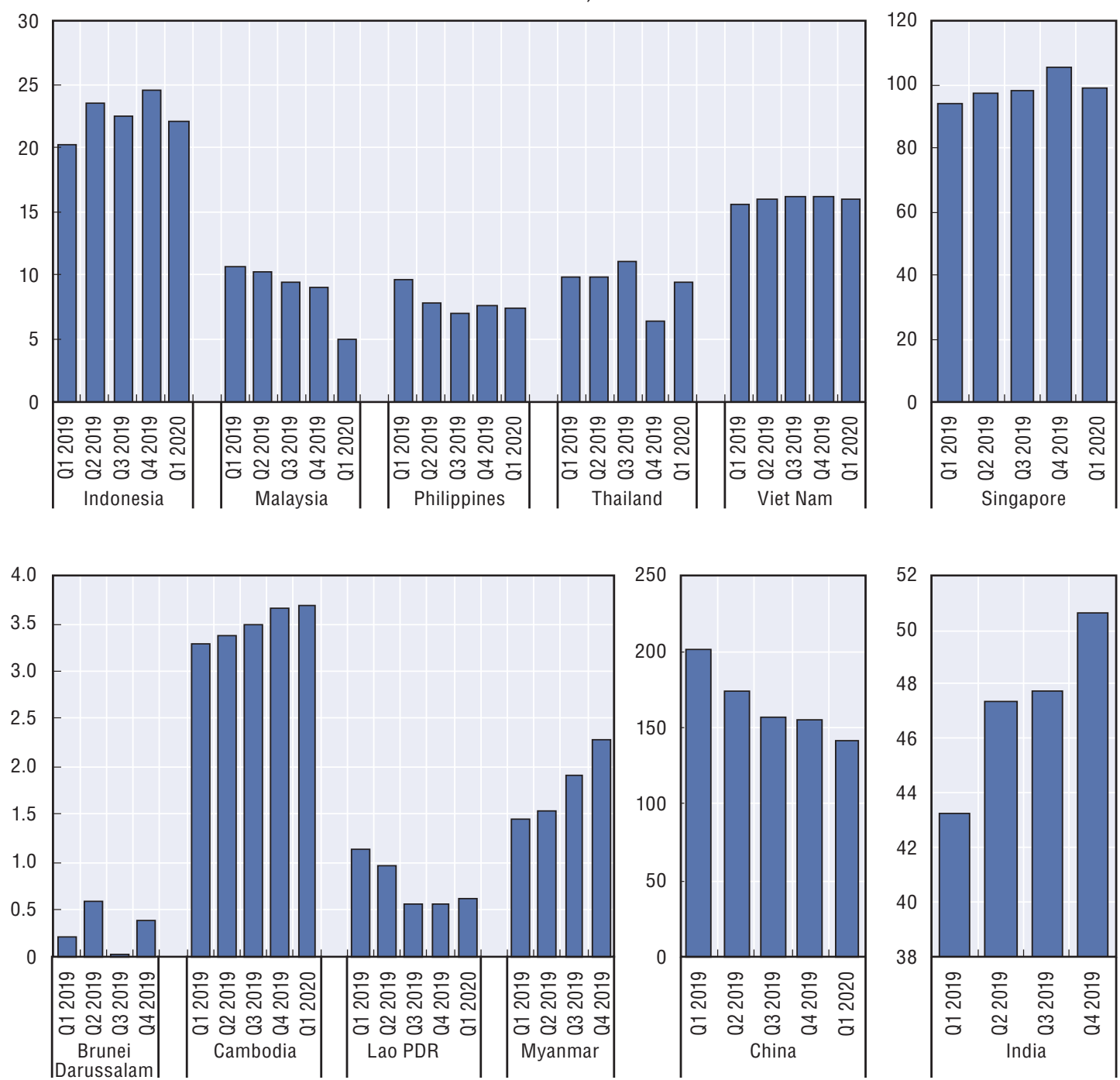

Note: Quarterly data are annualised (i.e. four-quarter sum). The asset/liability principle is followed in the presentation of FDI data. FDI inflow data refer to foreign placements minus foreign withdrawals (Balance of Payments liability side). The data are as of 26 June 2020.

Source: OECD Development Centre calculations based on CEIC data, national sources and IMF International Financial Statistics database.

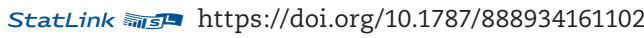


Meanwhile, the flood of liquidity into global financial markets - in a way that makes it appear almost like helicopter money - will have repercussions on the volatility of crossborder capital flows over the next few quarters. Lessons could be drawn from recent experience. Protraction of low interest rates puts pressure on institutional investors to take more risks. This includes social security and pension offices, which must try to keep pace with their fixed financial obligations. The "taper tantrum" panic of 2013 is a reminder of the importance of robust external positions when conditions tighten again. As described by Hofmann, Shim and Shin (2020), a deep stock of foreign reserves enabled central banks "to lean against currency depreciation and capital outflows" and is associated with smaller currency depreciations among emerging market economies, thus limiting financial stress.

Currency volatility can be a direct consequence of swings in capital flows. The adjustments made by monetary authorities have been effective in controlling currency pressures early in 2020. Emerging Asian currencies have mostly lost some ground against the fiat of their major trading partners to reverse the sustained strengthening since the latter part of 2019 (Figure 1.33). The Indonesian rupiah and the Thai baht, which were under heavy stress in Q1 2020, have recovered on strong policy signalling. The Chinese yuan renminbi and the Philippine peso, on the other hand, are appreciating. The weakness in the region's currencies is even starker against the US dollar (Figure 1.33). The exception is the Myanmar kyat, which has sustained its surge since January 2018. The country's current account balance has improved significantly in recent quarters owing to a smaller trade deficit and rising remittance inflows. Myanmar has also just transitioned to the market-determined reference exchange rate mechanism, which according to the IMF (2020d) is essential for effectively managing market expectations and informal market currency activities. Overall, volatility in the region's currencies has been relatively contained so far, even in an uncertain environment. Yet the risk of sharp disruptions in the coming months cannot yet be discounted.

Significant changes in the landscape from about a decade ago could complicate policy decisions on mitigating capital flow volatility and its impact in the region. These changes include the ongoing trade tension, the liquidity levels prior to the new rounds of quantitative easing and the low interest rates in many countries. The ability of policy makers to keep macroeconomic fundamentals sound during the recovery process, which may prove challenging given the circumstances, will be essential for smoothing cross-border capital movement. This will likewise have significant implications on exchange rate movements going forward.

\section{Figure 1.33. Changes in nominal effective and US dollar exchange rates in Emerging Asia, 2019-20 \\ Percentage}

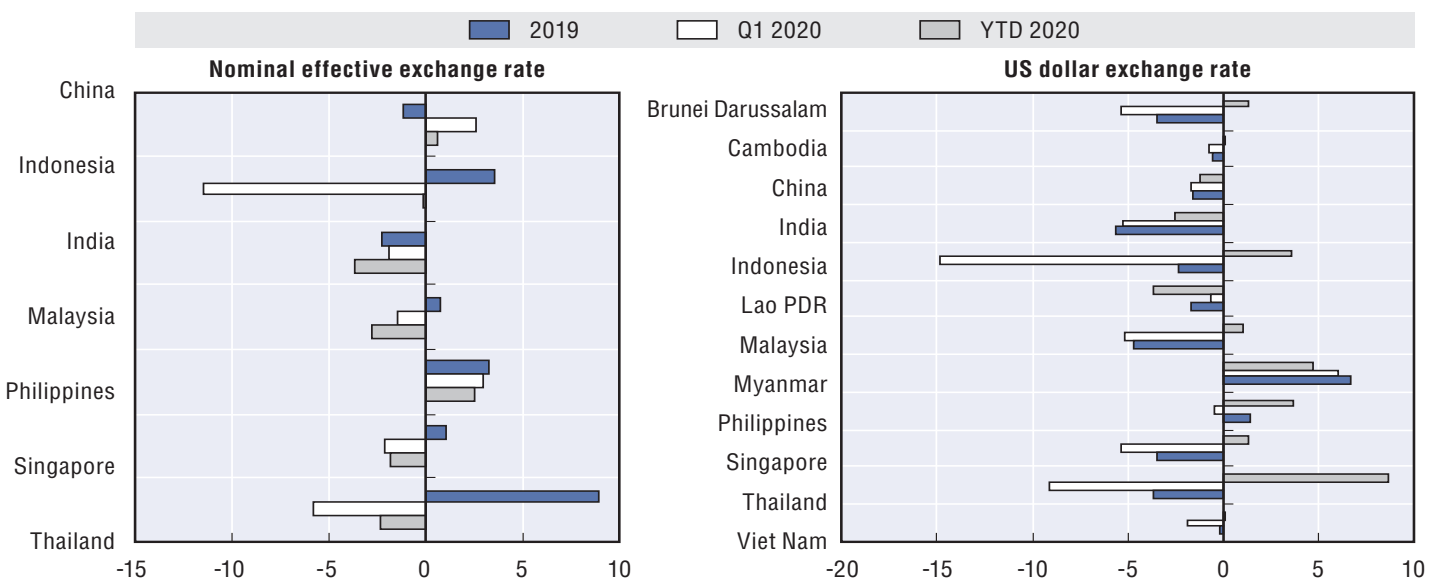

Note: YTD means year-to-date. Data are as of 23 June 2020 for the nominal effective exchange rate and 26 June 2020 for the US dollar exchange rate.

Source: OECD Development Centre based on BIS and Fusion Media Ltd, www.investing.com.

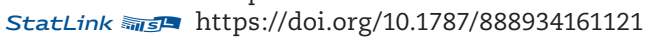




\section{Inflation in the region has moderated, but oil prices could surge anew}

Headline inflation in the region has moderated overall, leaving some space for monetary accommodation. Price pressures that were building due to supply-side disturbances are slowly dissipating. However, low global oil prices, which weighed on overall inflation in the first few months of the year, are on an upward trend. The price controls instituted when tight quarantine measures were imposed are also being wound down.

Curtailment of the cross-border movement of key staples due to the pandemic has affected supply channels domestically and internationally. This was exacerbated by African swine flu, which is still spreading across a number of Asian countries, resulting in livestock losses. Outbreaks continued in March in China, Cambodia, Indonesia, Lao PDR, Myanmar, the Philippines and Viet Nam, according to the Food and Agriculture Organization (FAO, 2020), and the disease was still present in many localities across the region in June, according to the World Organisation for Animal Health (2020).

A severe drought in the lower Mekong area in the first few months of 2020 has likewise dampened the supply of key staples and countered the demand slowdown's effects on prices. Dry season is over in the area and conditions have improved, but scattered hotspots persisted in Cambodia and Thailand in early June, with isolated hotspots also detected in Myanmar, Lao PDR and southern Viet Nam (Mekong River Commission, 2020).

Global oil prices have regained substantial ground since the end of April after a sharp downturn in the first four months of the year. Brent futures prices have more than doubled since hitting a trough just over two months ago. While oil prices are still down by more than $30 \%$ from the same period in 2019 , their upward trajectory - driven by oil supply cuts agreed by the major oil-producing countries - could reignite overall inflation. At the same time, countries have started to lift temporary price controls or freezes that were imposed on essential goods in response to COVID-19. This shift is underpinned by stability in supplies and the gradual re-opening of mainstream business sectors.

In China, food inflation has ebbed after pushing headline inflation to a multi-year high at the start of the year (Figure 1.34). The livestock industry has incurred heavy losses from the swine flu outbreak, which began more than a year ago. Moreover, lockdowns have disrupted the flow of goods, but stability in the prices of other commodity groups has anchored overall price momentum. Moving forward, the re-opening of supply lines should help mitigate upward price pressure, but stimulus measures to lift consumer demand will produce pressure in the opposite direction. 
Figure 1.34. Headline, core and food inflation in Emerging Asia, 2018-20
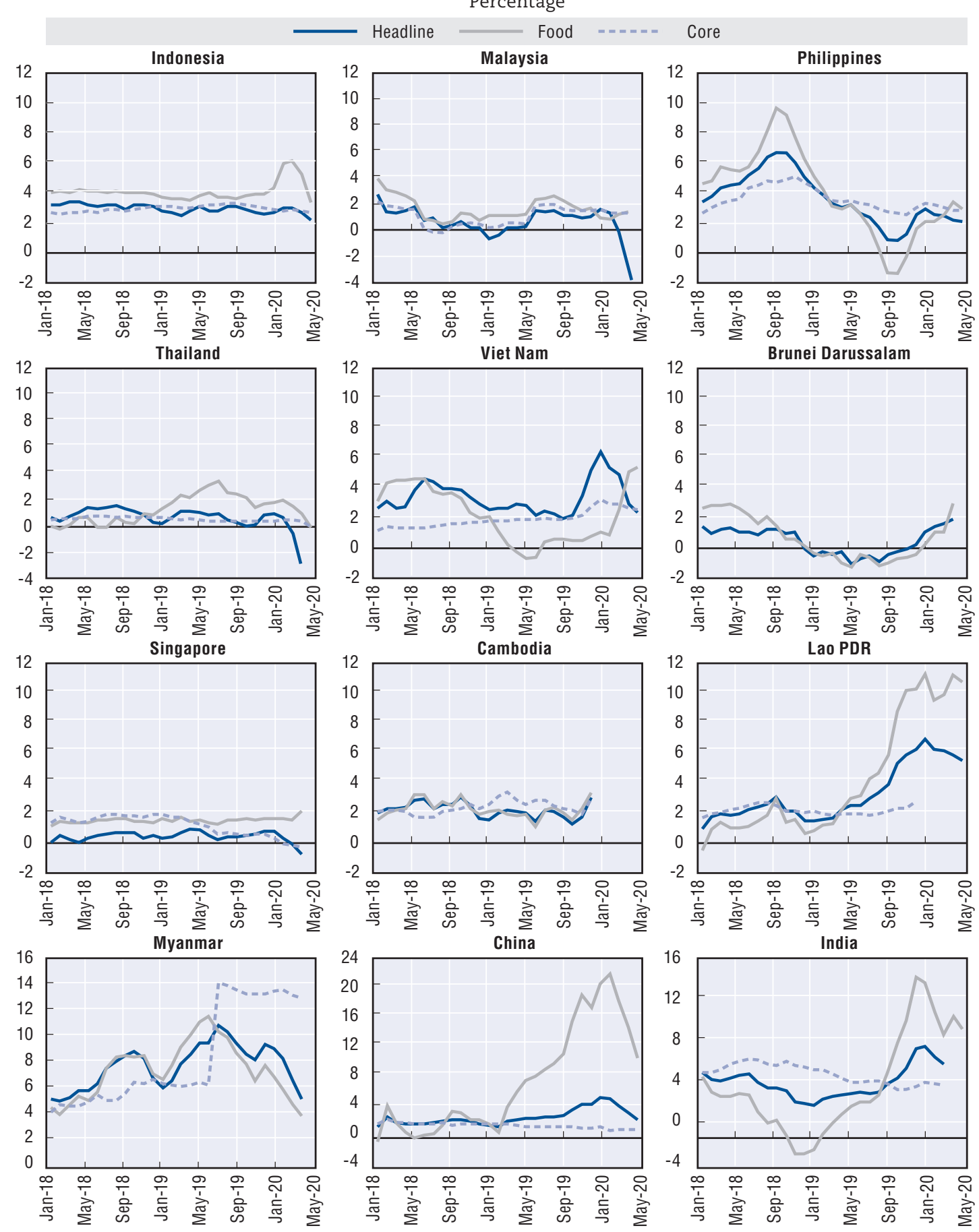

Note: Indonesia revised its inflation series starting January 2020. While the backseries of the CPI was made available, the new food and core inflation data only start in January 2020 (series break) and the back series of the corresponding indices only begins in January 2019. Food inflation refers to "Food, Beverage and Tobacco". The back series of the previous "Food" inflation has not yet been published to calculate the changes. All-India General CPI has not been compiled for the months of April and May 2020. Only selected price indices are published (e.g. food). India's core inflation refers to CPI excluding food and beverages and fuel and light. Lao PDR's core inflation data have not been updated since the release of October 2019 data. Data are as of 21 June 2020.

Source: OECD Development Centre based on CEIC and national sources.

StatLink 게내 https://doi.org/10.1787/888934161140 
India's headline consumer price index (CPI) has also lost steam in recent months. CPI growth from December 2019 to February 2020 breached the upper limit of the central bank's inflation target band of $2 \%$ to $6 \%$. Food prices began a steep climb due to supply issues affecting some farm products, but a recent pullback in these prices has helped contain headline CPI. Growth in the housing price index has remained on a downward path, though the relaxation of lending limits for property and other items is expected to cushion wavering demand. A cash reserve ratio exemption rule on incremental credit, favouring sectors including housing, was due to remain in effect until end of July (RBI, 2020b).

In Southeast Asia, Lao PDR and Myanmar were hurt by high headline inflation, though recent data indicate that it has peaked. Rising food prices have moderated in Myanmar but remain a concern in Lao PDR. However, the price indices of non-food items, such as housing, utilities, alcoholic beverages and tobacco and health, continue to rise sharply in Myanmar, in contrast to Lao PDR. A one-off tariff hike initiated by the Myanmar government in mid-2019 to prop up revenues of state enterprises is feeding price pressures. Food prices are similarly rising fast in Viet Nam, though the price indices of the other commodity groups have increased more slowly. Housing and construction prices, which were coming in strong just before the COVID-19 lockdown, have since retreated.

Elsewhere in Emerging Asia, headline CPI is somewhat moderate. Increases in food prices have been relatively benign in Brunei Darussalam, Cambodia, Indonesia, Malaysia, the Philippines, Singapore and Thailand. Higher "sin taxes" in the Philippines have kept the price index growth of alcoholic beverages and tobacco in double digits. This is offset by a contraction in the transportation index from March to May 2020.

\section{Box 1.11. Oil prices add to the pressure on Emerging Asian economies}

The spot price of World Texas Intermediate (WTI), the US benchmark, moved into negative territory for the first time in its history during the pandemic, closing at USD - $36.98 / \mathrm{barrel}$ on 20 April (Figure 1.35). The drop reflected the glut in US inventories and the fundamental weakening of global demand, which was already apparent before the COVID-19 crisis. Although Brent crude held up better, on 21 April the international benchmark traded at its lowest level in more than three decades. Oil prices have bounced back since then. However, the daily production cut decided by the Organisation of Petroleum Producing Countries (OPEC) may be insufficient to offset the decline in demand as a result of lower economic activity worldwide.

Figure 1.35. Crude oil spot prices, 1988-2020 USD per barrel

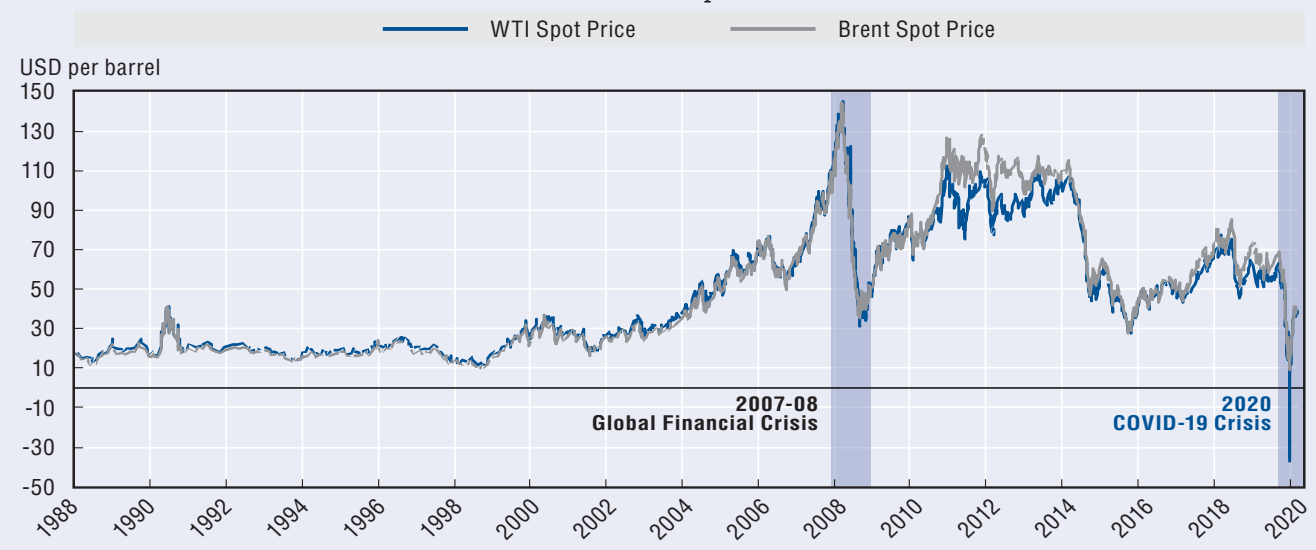

Note: The cut-off date is 29 June 2020.

Source: OECD Development Centre based on data from the US Energy Information Administration. StatLink 形) https://doi.org/10.1787/888934161159 


\section{Box 1.11. Oil prices add to the pressure on Emerging Asian economies (cont.)}

The combined share of ASEAN, China and India in global crude oil production amounted to approximately $7.7 \%$ at the end of 2019, according to US Energy Information Administration data. The largest producers in the region are China, with $4.6 \%$ of global crude production, followed by Indonesia $(0.9 \%)$, India $(0.8 \%)$ and Malaysia $(0.8 \%)$. While Malaysia and Brunei Darussalam account for only $0.8 \%$ and $0.1 \%$ of global production, respectively, they are net oil exporters to the rest of the world. Brunei Darussalam runs the largest oil trade balance surplus in ASEAN: in 2017, the Sultanate exported USD 2.71 billion worth of crude petroleum and imported USD 272 million. Malaysia's crude exports amounted to USD 6.4 billion in 2019, while imports stood at USD 6.2 billion.

Lower prices stand to reduce export earnings and fiscal revenues, with significant spillovers to the other sectors of the economy, but the net effect of the oil price decline in Emerging Asia is not yet clear. As densely populated large consumers, China and India are likely to benefit from the standpoint of consumption, even though they are also oil producers. China imported a record 11.34 million barrels a day in May 2020 (General Administration of Customs, People's Republic of China, 2020), while India spent USD 112 billion on oil imports in FY 2018-19, up from USD 88 billion in the previous fiscal year (CEIC data). More generally, industrial sectors that rely heavily on oil will see their energy bills shrink. The largest gainers are air and road transport companies as well as producers of petroleum-derived products. The fall in oil prices could also benefit consumers, providing producers of non-energy goods adjust their prices (ECB, 2018).

The sharp oil price drop in April took its toll on global risk assets. Equity markets reacted first, with declines of 3.2\% in India, 2.2\% in Malaysia and 1.6\% in Indonesia. Access to funding through global financial markets is likely to tighten in the near to medium term, to the extent that credit ratings are an indication of credit risk. Credit rating agencies have reviewed their sovereign rating outlook downwards for several oil producers in Emerging Asia. On 9 April, Fitch Ratings changed Malaysia's long-term sovereign rating to "negative" from "stable", citing the effects of the COVID-19 crisis on domestic economic activity and a deterioration in export earnings. Indonesia's sovereign rating was revised to "negative" from "stable" by S\&P Global Ratings on 17 April, while PT Saka Energi, one of Indonesia's largest oil and gas companies, was downgraded by Moody's on 30 April. Further such actions cannot be ruled out as credit rating agencies adjust their outlook for energy markets.

\section{Current account balances head downwards}

Emerging Asia's current account balances held up well in Q1 2020, although readings are expected to be generally weaker this year than in 2019 (Figure 1.36). With the exception of China, there has been no significant deterioration in positions so far in countries where data are available. The stability has helped to contain depreciation risks to domestic currencies. It is also crucial for keeping investor pessimism regarding economic fundamentals at bay. 
Figure 1.36. Current account balances in ASEAN, China and India, 2019-21 Percentage of GDP

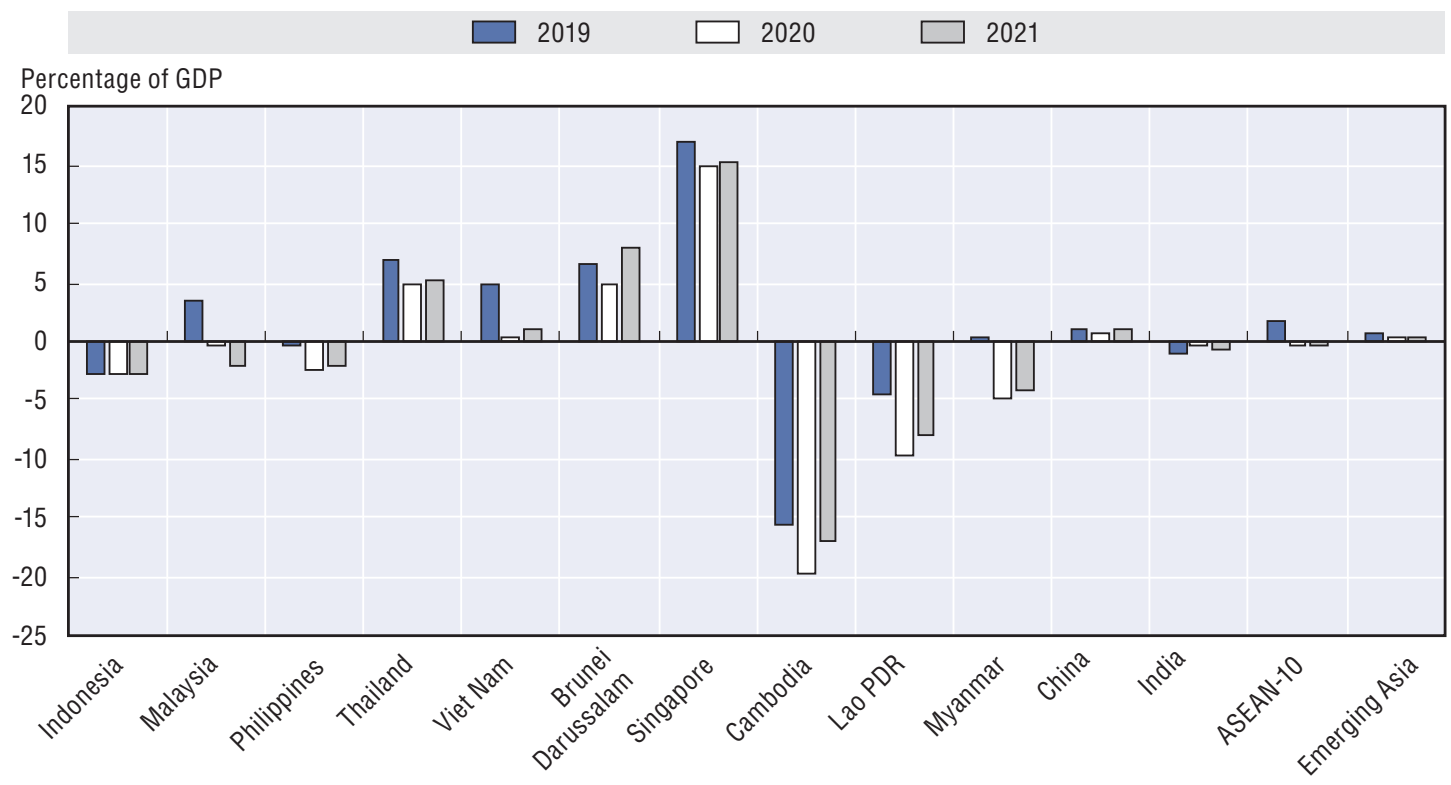

Note: Data are as of 26 June 2020. Data for India and Myanmar relate to fiscal years. Data for 2019 are based on CEIC and national sources. The 2019 nominal GDP of Lao PDR is from the IMF World Economic Outlook April 2020. The projections for China, India and Indonesia for 2020 and 2021 are based on the OECD Economic Outlook 107 (database). The projections assume "single hit" scenarios, in which a second big outbreak is avoided. They also assume that world GDP is declining in 2020 but will almost regain pre-crisis level (2016 level) in 2021.

Source: OECD Development Centre.

StatLink त्ञाज https://doi.org/10.1787/888934161178

China recorded a current account deficit for the first time in seven quarters as net trade turned negative. While trade flows declined both ways, export revenues posted a much larger decline than import payments. Indonesia's current account deficit moderated. The robustness of non-oil and gas exports moved trade into a surplus from a deficit in the previous quarter, but net outflows of primary income remained substantial. In contrast, Malaysia and Thailand maintained a fairly stable level of current account surplus in Q4 2019. In Malaysia, the trade surplus remains large despite a recent fall. The decrease in net trade was also compensated by a reduction in the net primary income deficit. In Thailand, a current account surplus was mainly supported by the large net trade position.

In the coming months, continuing tight border restrictions for shipments will be a significant dampening factor for cross-border trade, while a flare-up of trade tension could further complicate the environment. The erosion of trade could be accompanied by firm closures, with potential longer-term implications on trade capacity. Nonetheless, the recovery in real-sector conditions in advanced economies, even if slow, augurs well for external activities. Potential changes in the partial suspension of Cambodia's trade privileges with the European Union, its largest export market, will also be material.

Furthermore, remittances from foreign workers are likely to decline significantly, with many lost jobs unlikely to be restored in the short-term. In Cambodia, Myanmar, India, the Philippines and Viet Nam, the current account support provided by offshore workers' remittances could dissipate. For overseas contractual workers and shipboard workers, renewal of work arrangements will not be straightforward (Box 1.3). The business climate facing the cargo shipping and cruise tourism industries understandably remains grim. Cross-border controls for land-based workers have likewise tightened significantly. 


\section{Conclusion}

The COVID-19 pandemic will weaken economic performance across Emerging Asia in 2020 relative to the previous year, but significantly stronger GDP growth is expected in all 12 economies in 2021 if crippling new waves of infection do not take place.

The high global socio-economic toll of the pandemic is still rising, and will likely end decades of uninterrupted positive growth in many Emerging Asian countries. The health crisis has virtually shut down the global travel and tourism industry. Lockdown measures and business uncertainties have weighed on private consumption and investment. Firms have closed and people have lost jobs. To limit economic damage, restrictions have been eased in many parts of world, even in countries that still confront rising cases of infections. This convolutes the recovery process, especially when health systems are already stressed beyond their limits.

Emerging Asian economies have generally addressed the pandemic through tight quarantine measures coupled with fiscal and monetary support. The impact of these policy actions has been mixed, given variations in execution. As of mid-July, India, Indonesia and the Philippines were still struggling to slow virus transmission. Under these circumstances, business sectors cannot take full advantage of the easing of restrictions to recoup their losses and jumpstart job market recovery. Government delivery on additional fiscal commitments is also limited by the pandemic's impact on fiscal revenue intake in light of the economic slowdown.

Financial markets in the region have been under immense stress in the last few months, yet they have withstood the headwinds arguably well thus far. The concern is that the risks associated with capital flow volatility, banking sector profitability and solvency may continue to broaden in the absence of a clear way out of the crisis. Countries with outstanding banking stability issues, like India and to some extent Lao PDR, Myanmar and Viet Nam, may be more susceptible to additional shocks. However, any country in the region would face major problems if unemployment and firm closures were to rise to uncomfortable levels. Consequently, the macroeconomic fundamentals in the next few months could influence vulnerability to cross-border capital flow disruption.

\section{Notes}

1. Lockdowns are defined and implemented differently across jurisdictions.

2. National government support pertains to measure 5 in the policy tracker. Monetary and credit market support pertains to measures 1 to 4 . International assistance and packages with no breakdown pertain to measures 9 and 10. The data are as of 21 June 2020.

3. A COVID-19 fund for the countries of the South Asian Association for Regional Co-operation (SAARC) was proposed by India's leadership and it obtained pledges from the subregional members. The SAARC Disaster Management Centre was likewise set up and development of the SAARC COVID-19 Information Exchange Platform was set in motion.

4. Estimate based on the assumption of a 21-day lockdown period.

5. The credit ratings pertain to the long-term foreign currency credit ratings assessed by Standard \& Poor's, Moody's and Fitch Group.

6. The data of China, Indonesia and the Philippines are as of May; Cambodia, India and Malaysia are as of April; and Thailand as of March. The other Emerging Asian economies do not publish or have not yet published monthly data in the period of March to May 2020.

7. The sources of country-level policy actions are central banks and IMF (2020a).

8. China, India, Indonesia, Korea, Malaysia, the Philippines and Thailand.

9. While the outlook has been revised downwards, Malaysia's Long-Term Foreign-Currency Issuer Deafult Rating was maintained at "A-". 


\section{References}

Acuité Ratings \& Research (2020), "Impact of COVID-19 on GDP growth of FY21", https://www. acuite.in/Sector-alert-Impact-of-COVID-19-on-GDP.htm.

ADB (2020), ADB COVID-19 Policy Database, Asian Development Bank, Manila, https://covid19policy. adb.org/ (accessed on 21 June 2020).

ADB (2018), Economic Indicators for Eastern Asia: Input-Output Tables, Asian Development Bank, Manila, http://dx.doi.org/10.22617/TCS189778-2.

Bangko Sentral ng Pilipinas (2020a), "Consumer confidence remains optimistic for Q1 2020, less upbeat for the next quarter and the next 12 months", Bangko Sentral ng Pilipinas, Manila, http:// www.bsp.gov.ph/downloads/Publications/2020/CES_1qtr2020.pdf.

Bangko Sentral ng Pilipinas (2020b), "BSP Announces Extraordinary Measures to Support Domestic Liquidity", Bangko Sentral ng Pilipinas, Manila, http://www.bsp.gov.ph/publications/media.asp?id=5352.

Bangko Sentral ng Pilipinas (2020c), "BSP cuts RRR by 200 Bps to boost domestic liquidity amidst COVID-19 pandemic", Bangko Sentral ng Pilipinas, Manila, http://www.bsp.gov.ph/publications/ media. asp?id $=5331$.

Bank Indonesia (2020), "BI issued implementing provisions for auction of government debt securities (sun) and/or government Islamic securities (SBSN) in the primary market", Bank Indonesia, Jakarta, https://www.bi.go.id/en/ruang-media/info-terbaru/Pages/BI-TerbitkanKetentuan-Pelaksanaan-Lelang-SUN-dan-atau-SBSN-Jangka-Panjang-di-Pasar-Perdana.aspx.

Bappenas (2020a), "SDGs: Solusi Bersama Pulihkan Indonesia Pascapandemi Covid-19”, 15 May, Jakarta, https://www.bappenas.go.id/id/berita-dan-siaran-pers/sdgs-solusi-bersama-pulihkanindonesia-pascapandemi-covid-19/.

Bappenas (2020b), “Atasi Kontraksi Pertumbuhan Ekonomi Akibat Covid-19, Menteri Suharso Bahas Jaring Pengaman Sosial, Stunting, hingga IKN”, 11 May, Jakarta, https://www.bappenas.go.id/ id/berita-dan-siaran-pers/atasi-kontraksi-pertumbuhan-ekonomi-akibat-covid-19-menterisuharso-bahas-jaring-pengaman-sosial-stunting-hingga-ikn/.

Bauwens, M., et al. (2020), "Impact of coronavirus outbreak on NO2 pollution assessed using TROPOMI and OMI observations", Vol. 47/11, American Geophysical Union, Washington, DC, http://dx.doi.org/10.1029/2020GL087978.

Borio, C. (2019), "Central banking in challenging times" (speech), Bank for International Settlements, Basel, https://www.bis.org/speeches/sp191108a.pdf.

Bown, C. (2020), “US-China phase one tracker: China's purchases of US goods", Peterson Institute for International Economics, Washington, DC, https://www.piie.com/research/piie-charts/uschina-phase-one-tracker-chinas-purchases-us-goods.

CSIS (2020), Southeast Asia Covid-19 Tracker (web page), Center for Strategic and International Studies, Washington, DC, https://www.csis.org/programs/southeast-asia-program/southeastasia-covid-19-tracker-0 (accessed on 22 May 2020).

ECB (2018), "Economic and monetary developments", ECB Economic Bulletin, Issue 6/2018, European Central Bank, Frankfurt, https://www.ecb.europa.eu/pub/economic-bulletin/html/eb201806. en.html\#IDofOverviewes_Eb.

European Commission (2020), "Trade/Human Rights: Commission decides to partially withdraw Cambodia's preferential access to the EU market", Brussels, https://trade.ec.europa.eu/doclib/ press/index.cfm?id=2113\#: :text=The\%20European\%20Commission\%20has\%20decided,on\%20 Civil\%20and\%20Political\%20Rights.

FAO (2020), "ASF situation in Asia update" (5 March), Food and Agriculture Organization of the United Nations, http://www.fao.org/ag/againfo/programmes/en/empres/ASF/situation_update.html.

Flemming, S. (2020), "Viet Nam shows how you can contain COVID-19 with limited resources", World Economic Forum, Geneva, https://www.weforum.org/agenda/2020/03/vietnam-containcovid-19-limited-resources/.

Friedman, M. (1969), “The Optimum Quantity of Money.” The Optimum Quantity of Money and Other Essays, 1-50, Aldine Transaction, Chicago.

Hofmann, B., I. Shim and H.S. Shin (2020), "Emerging market economy exchange rates and local currency bond markets amid the COVID-19 pandemic", BIS Bulletin No. 5, Bank for International Settlements, Basel, https://www.bis.org/publ/bisbull05.pdf.

Horn, S. J. Meyer and C. Trebesch (2020), "European Community bonds since the oil crisis: Lessons for today?", Kiel Policy Brief No. 136. Kiel Institute for the World Economy, Kiel, https://www. ifw-kiel.de/fileadmin/Dateiverwaltung/IfW-Publications/-ifw/Kiel_Policy_Brief/kiel_policy brief_136_en.pdf. 
IATA (2020), "25 million jobs at risk with airline shutdown", Press Release, International Air Transport Association, Geneva, https://www.iata.org/en/pressroom/pr/2020-04-07-02/.

IHS Markit (2020), "IHS Markit Malaysia Manufacturing PMI: Manufacturing downturn eases sharply during May", IHS Markit, London, https://www.markiteconomics.com/Public/Home/ PressRelease/bcc5d8dc30944e3894c609c899d0d548.

IIF (2020), "Capital flows report: Sudden stop in emerging markets", 9 April 2020, Institute of International Finance, https://www.iif.com/Portals/0/Files/content/2_IIF2020_April_CFR.pdf (accessed on 24 April 2020).

IMF (2020a), Policy Responses to COVID-19 Policy Tracker (database), International Monetary Fund, Washington, DC, https://www.imf.org/en/Topics/imf-and-covid19/Policy-Responses-toCOVID-19 (accessed on 21 June 2020).

IMF (2020b), World Economic Outlook April 2020 (database), International Monetary Fund, Washington, DC, https://www.imf.org/external/pubs/ft/weo/2019/02/weodata/index.aspx (accessed on 24 May 2020).

IMF (2020c), Fiscal Monitor (database), International Monetary Fund, Washington, DC, https://www.imf.org/en/Publications/FM/Issues/2020/04/06/fiscal-monitor-april-2020 (accessed on 24 May 2020).

IMF (2020d), "Myanmar: 2019 Article IV Consultation-Press Release; Staff Report; and Statement by the Executive Director for Myanmar", International Monetary Fund, Washington, DC, https://www.imf.org/ /media/Files/Publications/CR/2020/English/1MMREA2020003.ashx.

Johns Hopkins (2020), COVID-19 Map (database), Coronavirus Research Center, Johns Hopkins University \& Medicine, Baltimore, MD, https://coronavirus.jhu.edu/map.html.

Mekong River Commission (2020), "Weekly dry season situation report for the Mekong River Basin", week of 26 May to 1 June 2020, Regional Flood and Drought Management Centre, Mekong River Commission, https://reliefweb.int/sites/reliefweb.int/files/resources/2020-06-02\%20 Weekly\%20Dry\%20Season\%20Situation.pdf

Ministry of Economy and Finance-Cambodia (2020), "Flash report for April 2020: Socio-economic trends", Phnom Penh, https://www.mef.gov.kh/documents/shares/publication/flash report/ Flash_Report_202004_EN.pdf.

Ministry of Finance and Economy-Brunei Darussalam (2020), "Measures undertaken by the government in addressing the impact of COVID-19 in Brunei Darussalam", Bandar Seri Begawan, https://www.mofe.gov.bn/Shared\%20Documents/MEASURES\%20UNDERTAKEN\%20BY\%20 THE\%20GOVERNMENT\%20IN\%20HANDLING\%20THE\%20IMPACT\%20OF\%20COVID-19\%20\%20 issued\%2027.04.2020\%20v7.pdf.

Ministry of State Secretariat-Indonesia (2020), "Peraturan pemerintah Republik Indonesia tentang pelaksanaan Program Pemulihan Ekonomi Nasional”, Jakarta, https://jdih.setneg.go.id/ viewpdfperaturan/P18872/PP\%20Nomor\%2023\%20Tahun\%202020.

Moody's (2020), “Rating action: Moody's downgrades India's ratings to Baa3, maintains negative outlook", Moody's, New York, https://www.moodys.com/research/Moodys-downgrades-Indiasratings-to-Baa3-maintains-negative-outlook--PR 424605.

MTI Singapore (2020), “MTI downgrades 2020 GDP growth forecast to '-7.0 to -4.0 Per Cent'” (press release),Ministry of Trade and Industry, Singapore, https://www.singstat.gov.sg/-/media/files/ news/gdp1q2020.pdf.

National Bureau of Statistics of China (2020a), "The performance of national economy continued to improve with major indicators manifesting positive changes in April", Beijing, http://www. stats.gov.cn/english/PressRelease/202005/t20200515 1745635.html.

National Bureau of Statistics of China (2020b), "National economy continued to recover in May", Beijing, http://www.stats.gov.cn/english/PressRelease/202006/t20200615 1760170.html.

NEDA (2020), We Recover as One, Inter-Agency Task Force Technical Working Group for Anticipatory and Forward Planning, National Economic and Development Authority of the Philippines, Manila, www.neda.gov.ph/wp-content/uploads/2020/05/We-Recover-As-One.pdf.

Pearce, B. (2020), “COVID-19: Assessing prospects for domestic markets”, International Air Transport Association, Geneva, https://www.iata.org/en/iata-repository/publications/economic-reports/ covid-19-assessing-prospects-for-domestic-markets/.

Prime Minister's Office of Malaysia (2020a), "All hands on deck to revive the economy-PM", 25 April 2020, Kuala Lumpur, https://www.pmo.gov.my/2020/04/all-hands-on-deck-to-revivethe-economy-pm/.

Prime Minister's Office of Malaysia (2020b), "PRIHATIN Economic Stimulus Package”, Kuala Lumpur, https://www.pmo.gov.my/prihatin-economic-stimulus-package/. 
RBI (2020a), "RBI announces 50,000 crore Special Liquidity Facility for Mutual Funds (SLF-MF)" (press release),Reserve Bank of India, Mumbai, 27 April 2020, https://rbidocs.rbi.org.in/rdocs/ PressRelease/PDFs/PR22761B4E43FCBED94A12955FD65458EBEEDA.PDF.

RBI (2020b), "Edited transcript of Reserve Bank of India's sixth bi-monthly monetary policy press conference", Reserve Bank of India, Mumbai, https://rbidocs.rbi.org.in/rdocs/Content/PDFs/ CALL07022020A7E2053D4B2744779271EA49D7EEA88C.PDF

RBI (2019), Financial Stability Report, Issue 20, Reserve Bank of India, Mumbai, https://rbidocs. rbi.org.in/rdocs//PublicationReport/Pdfs/OFSRDECEMBER20198C840246658946159CB3B94E8516F2 EC.PDF.

Shi, X. and G.P. Brasseur (2020), "The response in air quality to the reduction of Chinese economic activities during the COVID-19 outbreak", Vol. 47/11, American Geophysical Union, Washington, DC, https://doi.org/10.1029/2020GL088070.

Tanaka, K. and M. Pezzini (2020), The Economic Implications of Lockdown in Emerging Asia, OECD Development Matters blog post, https://oecd-development-matters.org/2020/04/15/the-economic-implications-oflockdown-in-emerging-asia/.

UNCTAD (2020), UNCTAD-Eora GVC (database), United Nations Conference on Trade and Development, New York, https://www.worldmrio.com/unctadgvc/.

University of Oxford (2020), COVID-19 Government Response Tracker (database), Blavatnik School of Government, Oxford, England, https://www.bsg.ox.ac.uk/research/research-projects/ coronavirus-government-response-tracker\#data (accessed on 28 June 2020).

UNWTO (2020a), UN World Tourism Organisation, Madrid, https://doi.org/10.18111/9789284421459.

World Organisation for Animal Health (2020), "Situational updates of ASF in Asia and the Pacific" (web page), Tokyo, https://rr-asia.oie.int/en/projects/asf/situational-updates-of-asf/ (accessed on 27 June 2020). 


\section{Annex 1.1. Detailed summary of key macro-policy responses to COVID-19}

\begin{tabular}{|c|c|c|c|}
\hline & $\begin{array}{l}\text { Fiscal policy measures } \\
\text { (including income support schemes) }\end{array}$ & Monetary policy measures & Data sources \\
\hline \multicolumn{4}{|l|}{ ASEAN-5 } \\
\hline Indonesia & $\begin{array}{l}\text { - First stimulus package worth } \\
\text { USD } 725 \text { million in February } 2020 \text {, } \\
\text { to support the tourism, aviation and } \\
\text { property industries. The package also } \\
\text { allocated USD } 324 \text { million for low- } \\
\text { income households. } \\
\text { - Second emergency stimulus package, } \\
\text { worth USD } 8.1 \text { billion, which } \\
\text { included exempting some workers in } \\
\text { manufacturing from income tax and } \\
\text { giving manufacturing companies a } \\
\text { discount on corporate tax payments. } \\
\text { Third stimulus package worth nearly } \\
\text { USD } 24.5 \text { billion for healthcare spending, } \\
\text { social protection and tax incentives. } \\
\text { Increased benefits and broader coverage } \\
\text { of existing social assistance to low- } \\
\text { income households, such as food aid, } \\
\text { conditional cash transfers and electricity } \\
\text { subsidies, and expanded unemployment } \\
\text { benefits. } \\
\text { - On } 18 \text { May, USD } 43 \text { billion economic } \\
\text { stimulus to support } 12 \text { state-owned } \\
\text { enterprises, subsidise loan repayments } \\
\text { for about } 60 \text { million borrowers } \\
\text { and strengthen social safety net } \\
\text { programmes. } \\
\text { - Tax relief and exemptions, and } \\
\text { acceleration of VAT refund. } \\
\text { Cuts on corporate tax payments: from } \\
\text { the current } 25 \% \text { in } 2020 \text { to } 22 \% \text { in } \\
2021 \text {, and } 20 \% \text { for financial year } 2022 \\
\text { onwards. } \\
\text { USD } 75.7 \text { billion with allocated direct } \\
\text { income support of USD } 67.6 \text { billion, as } \\
\text { above. }\end{array}$ & $\begin{array}{l}\text { - Reduction in the policy rate by } 25 \text { bps to } \\
4.75 \% \text { in February, by } 25 \text { bps to } 4.5 \% \text { in } \\
\text { March and by another } 25 \text { bps to } 4.25 \% \\
\text { in June. } \\
\text { - Daily rupiah reserve requirement } \\
\text { lowered by } 50 \text { bps in March. } \\
\text { - Maximum duration for repo and reverse } \\
\text { repo operations increased (up to } \\
12 \text { months) and introduction of daily } \\
\text { repo auctions. } \\
\text { - Increased frequency of FX swap auctions } \\
\text { for } 1,3,6 \text { and } 12 \text {-month tenors from } \\
\text { three times per week to daily auctions. } \\
\text { - Relaxation of loan classification and } \\
\text { restructuring procedures. }\end{array}$ & 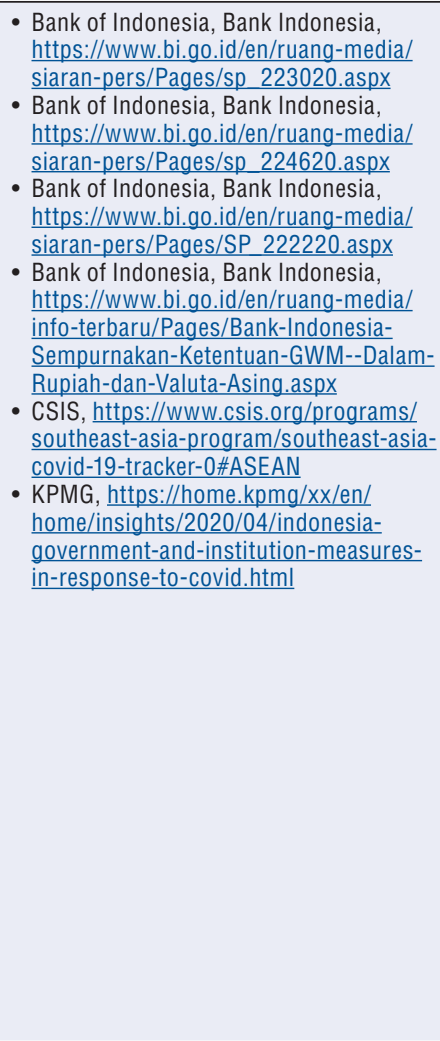 \\
\hline Malaysia & $\begin{array}{l}\text { - First economic stimulus packages } \\
\text { worth USD } 4.6 \text { billion announced on } \\
27 \text { February to cushion the impact of } \\
\text { COVID-19 for the tourism sector and } \\
\text { other industries. } \\
\text { - Second package includes } \\
\text { USD } 23.1 \text { billion for businesses and } \\
\text { USD } 2.3 \text { billion in direct cash payments } \\
\text { for } 4 \text { million low-income households. } \\
\text { - Third stimulus package on } 6 \text { April, worth } \\
\text { USD } 2.2 \text { billion, includes wage subsidies, } \\
\text { grants and loans for SMEs, and tax } \\
\text { deductions. } \\
\text { - Measures aimed at easing the cash } \\
\text { flow of affected businesses and sectors } \\
\text { (tourism, agriculture) and providing } \\
\text { financial aid to private and government } \\
\text { employees. } \\
\text { - Deferral on the payment of monthly } \\
\text { income tax instalments } \\
\text { Retirement scheme exemption and } \\
\text { postponement on rental payments for } \\
\text { housing and business premises. }\end{array}$ & $\begin{array}{l}\text { - Monetary stimulus response to support } \\
\text { credit financing and liquidity flows. } \\
\text { - Lowered the Overnight Policy Rate } \\
\text { (OPR) by } 25 \text { bps to } 2.50 \% \text { in March. } \\
\text { - Lowered the Statutory Reserve } \\
\text { Requirement (SRR) Ratio by } 100 \text { bps to } \\
2 \% \text { effective } 20 \text { March. } \\
\text { - Easing regulatory and supervisory } \\
\text { compliance on banks to enable } \\
\text { them to support loan deferment and } \\
\text { restructuring. } \\
\text { - Defer loan repayment under Skills } \\
\text { Development Fund Corporation (PTPK) } \\
\text { for } 6 \text { months to } 174500 \text { borrowers and } \\
\text { National Higher Education Fund (PTPTN) } \\
\text { loan repayments. }\end{array}$ & 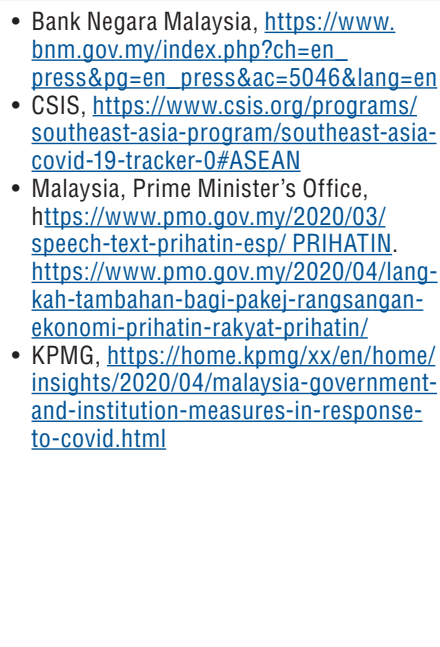 \\
\hline
\end{tabular}




\begin{tabular}{|c|c|c|c|}
\hline & $\begin{array}{c}\text { Fiscal policy measures } \\
\text { (including income support schemes) }\end{array}$ & Monetary policy measures & Data sources \\
\hline Philippines & $\begin{array}{l}\text { - Expansionary budget, with a planned } \\
12 \% \text { year-to-year increase of spending. } \\
\text { - Fiscal stimulus amounting to } \\
\text { USD } 11.9 \text { billion (PHP } 595 \text { billion) to } \\
\text { provide economic relief to businesses } \\
\text { and households affected by COVID-19. } \\
\text { Includes cash aid programme for } \\
18 \text { million low-income households, } \\
\text { social protection measures for } \\
\text { vulnerable workers including displaced } \\
\text { and overseas workers, and related health } \\
\text { medical response. } \\
\text { - Financial assistance for affected MSMEs } \\
\text { and vulnerable households including } \\
\text { wage subsidies. }\end{array}$ & $\begin{array}{l}\text { - Lower policy rate in } 2020 \text { by a } \\
\text { cumulative } 175 \text { bps, to } 2.25 \% \text { ( } 25 \text { bps } \\
\text { on } 6 \text { February, } 50 \text { bps on } 19 \text { March, } \\
50 \text { bps on } 16 \text { April and a further } 50 \text { bps } \\
\text { on } 25 \text { June). } \\
\text { - The minimum liquidity ratio (MLR) for } \\
\text { stand-alone thrift banks, rural banks and } \\
\text { cooperative banks was reduced from } \\
20 \% \text { to } 16 \% \text {. } \\
\text { - Purchase PHP } 300 \text { billion worth of } \\
\text { government securities to support } \\
\text { government programme to counter the } \\
\text { impact of COVID-19. } \\
\text { - Temporary relaxation of requirements } \\
\text { on compliance reporting, penalties on } \\
\text { required reserves, and single borrower } \\
\text { limits. } \\
\text { - Easier accessibility to rediscounting } \\
\text { facility. } \\
\text { - Temporary relaxation of provisioning } \\
\text { requirements. } \\
\text { - Temporary grace period for loan } \\
\text { payments. } \\
\text { - Suspension of all fees and charges } \\
\text { imposed on online banking platforms } \\
\text { during the period of regulatory relief. }\end{array}$ & 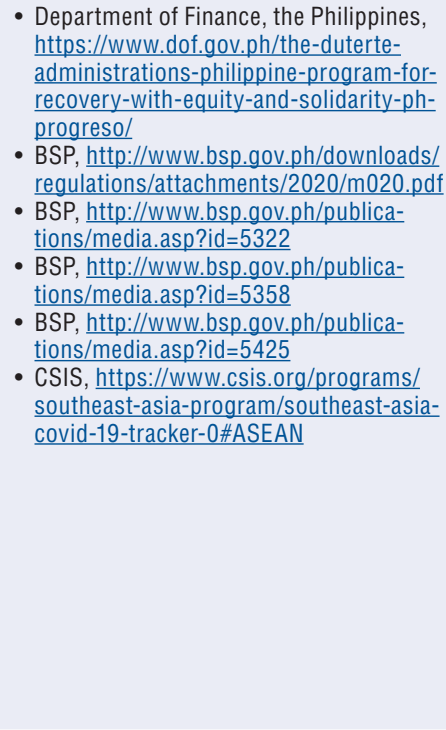 \\
\hline Thailand & $\begin{array}{l}\text { - Reduction of withholding taxes for } \\
\text { businesses, from } 3 \% \text { to } 1.5 \% \text {. } \\
\text { - Tax deduction for businesses of } \\
1.5 \text { times the interest rate paid from } 1 \\
\text { April } 2020 \text { to } 31 \text { December } 2020 \text { and } \\
3 \text { times the wage expenses paid from } \\
\text { April } 2020 \text { to July } 2020 \text {. } \\
\text { - Reduction or postponement of utility } \\
\text { bills. } \\
\text { - Increase infrastructure and jobs } \\
\text { investment. } \\
\text { - Fiscal package with } 3 \text { phases } \\
\text { amounting to at least THB } 1.9 \text { trillion } \\
\text { (USD } 41.6 \text { billion) including health- } \\
\text { related spending; assistance for workers } \\
\text { (including } 3 \text { million workers outside the } \\
\text { social security system), farmers and } \\
\text { entrepreneurs affected by COVID-19; } \\
\text { support for individuals and businesses } \\
\text { through soft loans from Specialised } \\
\text { Financial Institution (SFI) and Social } \\
\text { Security Office. }\end{array}$ & $\begin{array}{l}\text { - Policy rate was reduced by } 25 \text { bps on } \\
5 \text { February, by } 25 \text { bps on } 20 \text { March and } \\
\text { by another } 25 \text { bps on } 20 \text { May. } \\
\text { - Reductions in interest and/or fees. } \\
\text { - Relaxation of repayment conditions and } \\
\text { debt restructuring by suspending the } \\
\text { principal and reducing the interest rate } \\
\text { for debts. } \\
\text { - Low interest loans at } 3 \% \text { for the first } \\
2 \text { years provided to affected SME } \\
\text { entrepreneurs until } 30 \text { December } 2020 \text {, } \\
\text { and relaxation of the maximum limit of } \\
\text { personal loans for emergency cases. } \\
\text { - Reduced and cancelled BOT bond } \\
\text { issuance. }\end{array}$ & 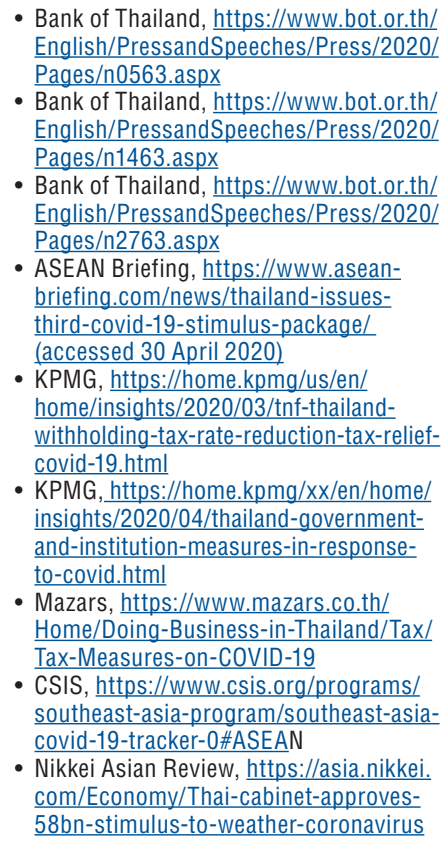 \\
\hline
\end{tabular}




\begin{tabular}{|c|c|c|c|}
\hline & $\begin{array}{c}\text { Fiscal policy measures } \\
\text { (including income support schemes) }\end{array}$ & Monetary policy measures & Data sources \\
\hline Viet Nam & $\begin{array}{l}\text { - Stimulus package estimated at } \\
\text { USD } 12.8 \text { billion to support health and } \\
\text { non-health services, including purchase } \\
\text { of medical equipment and materials; } \\
\text { special allowances for forces engaged } \\
\text { in epidemic prevention and control; } \\
\text { expenses for isolated people, medical } \\
\text { examination and treatment during the } \\
\text { isolation period, and other cash transfer } \\
\text { packages. } \\
\text { - Tax relief on delayed payments, tax } \\
\text { exemptions, streamlined tax and custom } \\
\text { audit and inspection at firms. } \\
\text { - Increased government spending on } \\
\text { infrastructure. }\end{array}$ & $\begin{array}{l}\text { - Benchmark policy rates cut by 50- } \\
100 \text { bps, the short-term deposit rates } \\
\text { cap by } 25-30 \text { bps, and the short-term } \\
\text { lending rates cap for priority sectors by } \\
50 \text { bps. } \\
\text { - Raised remuneration rates on required } \\
\text { Vietnamese dong (VND) reserves by } \\
20 \text { bps, raised interest rates by the } \\
\text { same amount on Vietnam Deposit } \\
\text { Insurance, Social Policy Bank, Vietnam } \\
\text { Development Bank, People Credit Funds } \\
\text { and microfinance institutions' deposits } \\
\text { at the SBV. } \\
\text { - Exemptions and reduced interest on } \\
\text { existing debts; reduced fees (including } \\
\text { interbank transaction fees for small } \\
\text { amounts, and credit information } \\
\text { subscription fees). }\end{array}$ & 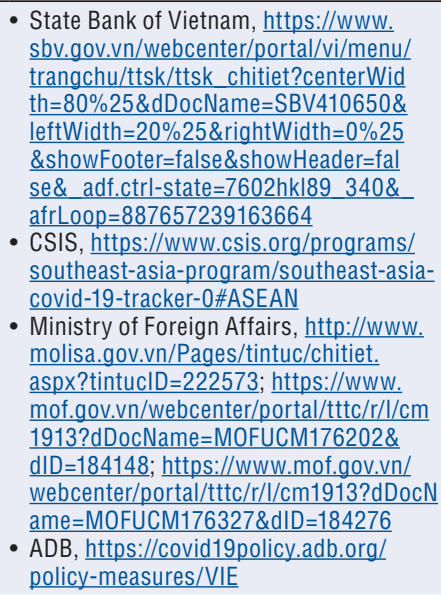 \\
\hline \multicolumn{4}{|c|}{ Brunei Darussalam and Singapore } \\
\hline $\begin{array}{l}\text { Brunei } \\
\text { Darussalam }\end{array}$ & $\begin{array}{l}\text { - Additional financial support } \\
\text { measures amounting to an estimated } \\
\text { BND } 250 \text { million (USD } 176.8 \text { million), } \\
\text { effective } 1 \text { April. } \\
\text { - Measures to support the private sector, } \\
\text { including a 30\% discount on rental rates } \\
\text { of government buildings for MSMEs } \\
\text { in the most affected sectors, a 50\% } \\
\text { discount on corporate income tax for } \\
2020 \text { for the most affected sectors and } \\
\text { a } 15 \% \text { discount on water and electricity } \\
\text { bills to firms in the most affected } \\
\text { sectors. }\end{array}$ & $\begin{array}{l}\text { - Six-month deferment of loan repayments } \\
\text { for all affected sectors including } \\
\text { importers of food and medical supplies. } \\
\text { - Restructuring and deferment of principal } \\
\text { amounts on personal loans and hire- } \\
\text { purchase facilities such as car loans or } \\
\text { financing (for not more than ten years). } \\
\text { - Deferment of principal amount or } \\
\text { financing for real estate. } \\
\text { - USD } 1.7 \text { million deferment of loan } \\
\text { repayments and exemption of charges } \\
\text { for SMEs. } \\
\text { - Restructuring the outstanding credit } \\
\text { card balance. } \\
\text { - Coupled with fiscal assistance, these } \\
\text { measures increase the value of the } \\
\text { stimulus package to BND } 450 \text { million } \\
\text { (USD } 318.1 \text { million). }\end{array}$ & $\begin{array}{l}\text { - Monetary Authority of Brunei Darus- } \\
\text { salam, https://ambd.gov.bn/Site\%20 } \\
\text { Assets\%20\%20News/2020-Press- } \\
\text { Statement-Banking-Sector-Interim- } \\
\text { - Measures-FINAL.pdf } \\
\text { Ministry of Finance and Economy, Brunei } \\
\text { Darussalam, https://www.mofe.gov.bn/ } \\
\text { Lists/News/NewDispForm.aspx? }=101 \\
\text { - Ministry of Finance and Economy, Brunei } \\
\text { Darussalam, https://www.mofe.gov.bn/ } \\
\text { Lists/News/NewDispForm.aspx?ID=108 }\end{array}$ \\
\hline Singapore & $\begin{array}{l}\text { - Increased budget support and spending. } \\
\text { - Four packages worth SGD } 63.7 \text { billion } \\
\text { (USD } 45.2 \text { billion). Funds allocated } \\
\text { for containing the outbreak amount } \\
\text { to about SGD } 800 \text { million). A Care and } \\
\text { Support Package provides support for } \\
\text { households (SGD } 5.7 \text { billion), including } \\
\text { a cash payout to all Singaporeans and } \\
\text { additional payments for lower-income } \\
\text { individuals and the unemployed. A } \\
\text { Stabilisation and Support Package for } \\
\text { businesses (SGD } 35.3 \text { billion) includes } \\
\text { wage subsidies, enhanced financing } \\
\text { schemes and additional support for } \\
\text { industries directly affected and the self- } \\
\text { employed. } \\
\text { - A fourth stimulus worth } \\
\text { USD } 23.2 \text { billion, the Fortitude Budget, } \\
\text { was unveiled on } 26 \text { May to support } \\
\text { workers and businesses affected by } \\
\text { border closures and social distancing } \\
\text { measures. }\end{array}$ & $\begin{array}{l}\text { - Extension of payment terms for trade } \\
\text { finance facilities. } \\
\text { - Additional financing for working capital. } \\
\text { - Establishment of a USD } 60 \text { billion swap } \\
\text { facility with the US Federal Reserve in } \\
\text { March } 2020 \text {, for at least six months, } \\
\text { with the aim of providing USD liquidity } \\
\text { to financial institutions in Singapore. } \\
\text { - Altered its exchange rate-based policy } \\
\text { stance by adopting a } 0 \% \text { per annum rate } \\
\text { of appreciation of the policy band and by } \\
\text { reducing the mid-point to the prevailing } \\
\text { level of the SGD Nominal Effective } \\
\text { Exchange Rate (NEER). } \\
\text { - Selected regulatory requirements } \\
\text { and supervisory programmes } \\
\text { adjusted by MAS on } 7 \text { April to enable } \\
\text { financial institutions to better deal } \\
\text { with pandemic-related issues. An } \\
\text { SGD } 125 \text { million support package to } \\
\text { sustain and strengthen financial services } \\
\text { and FinTech capabilities, funded by the } \\
\text { Financial Sector Development Fund, } \\
\text { with three main pillars: supporting } \\
\text { workforce training and manpower } \\
\text { costs; strengthening digitalisation and } \\
\text { operational resilience; and enhancing } \\
\text { Fintech firms' access to digital tools. }\end{array}$ & $\begin{array}{l}\text { - ASEAN Briefing, https://www.asean- } \\
\text { briefing.com/news/singapore-announc- } \\
\text { es-second-covid-19-stimulus-package- } \\
\text { - salient-features/ } \\
\text { CSIS, https://www.csis.org/programs/ } \\
\text { southeast-asia-program/southeast-asia- } \\
\text { - } \frac{\text { covid-19-tracker-0\#ASEAN }}{\text { Ministry of Finance, https://www.mof. }} \\
\text { gov.sg/newsroom/press-releases } \\
\text { - MAS, https://www.mas.gov.sg/news/ } \\
\text { media-releases/2020/new-grant- } \\
\text { scheme-to-support-singapore-fintech- } \\
\text { - irms } \\
\text { MAS, https:///www.mas.gov.sg/news/ } \\
\text { media-releases/2020/mas-announces- } \\
\text { swap-facility-with-the-us-federal- } \\
\text { - } \frac{\text { reserve }}{\text { MAS, https:///www.mas.gov.sg/news/ }} \\
\text { monetary-policy-statements/2020/mas- } \\
\text { monetary-policy-statement-30mar20 }\end{array}$ \\
\hline
\end{tabular}




\begin{tabular}{|c|c|c|c|}
\hline & $\begin{array}{l}\text { Fiscal policy measures } \\
\text { (including income support schemes) }\end{array}$ & Monetary policy measures & Data sources \\
\hline \multicolumn{4}{|c|}{ Cambodia, Lao PDR and Myanmar } \\
\hline Cambodia & $\begin{array}{l}\text { - Fiscal resources to the health sector of } \\
\text { around USD } 60 \text { million. } \\
\text { - Targeted capital injection to support } \\
\text { smaller firms and microfinance } \\
\text { institutions, and additional capital } \\
\text { injection for the Rural Development } \\
\text { Bank. } \\
\text { - Suspended workers provided with } \\
\text { income payments co-funded by firms } \\
\text { and government. } \\
\text { - A package including tax concessions, } \\
\text { wage subsidies and, streamlined capital } \\
\text { spending. }\end{array}$ & $\begin{array}{l}\text { - Credit support in the form of low-interest } \\
\text { loans; lower interest rate on Negotiable } \\
\text { Certificates of Deposit. } \\
\text { - Interest rate cut in Liquidity Providing } \\
\text { Collateralised Operations. } \\
\text { - Decreased bank funding costs in } \\
\text { domestic currency. } \\
\text { - Lowering of required reserves for local } \\
\text { and foreign currencies. }\end{array}$ & 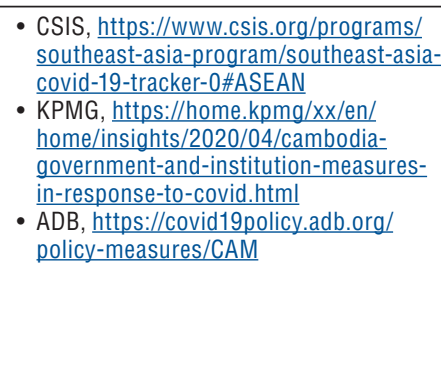 \\
\hline Lao PDR & $\begin{array}{l}\text { - Stimulus response amounting to } \\
\text { USD } 10.3 \text { million. } \\
\text { - New electricity tariff to ensure supply of } \\
\text { electricity, in effect from } 1 \text { May } 2020 \text { to } \\
31 \text { December } 2025 \text {. } \\
\text { - Revenue collection ensured through } \\
\text { automated platforms and inspections } \\
\text { targeting stockpiling of essential goods. } \\
\text { - Tax relief and exemptions. }\end{array}$ & $\begin{array}{l}\text { - Policy rate cuts from } 4 \% \text { to } 3 \% \text { or one- } \\
\text { week loans; from } 5 \% \text { to } 4 \% \text { for one-two } \\
\text { week loans; and from } 10 \% \text { to } 9 \% \text { for } \\
\text { two-week to one-year loans. } \\
\text { - Reduction in reserve requirements, from } \\
10 \% \text { to } 8 \% \text { on foreign exchange, and } \\
\text { from } 5 \% \text { to } 4 \% \text { on local currency. } \\
\text { - Loan restructuring and new loans to } \\
\text { businesses affected by the outbreak. } \\
\text { - Regulatory forbearance on loan } \\
\text { classification and provisioning. }\end{array}$ & 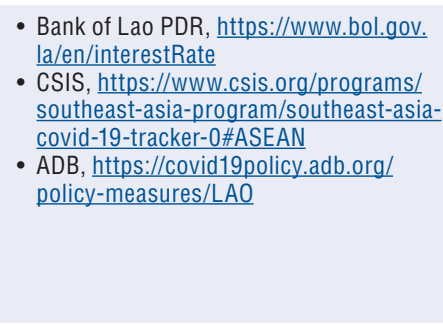 \\
\hline Myanmar & $\begin{array}{l}\text { - Extension on income and commercial } \\
\text { tax payments } \\
\text { - Exemption for the } 2 \% \text { advance income } \\
\text { tax on exports; reduced duties for } \\
\text { businesses operating with the Myanmar } \\
\text { Automated Cargo Clearance System } \\
\text { - Provide for } 40 \% \text { of the social security } \\
\text { fees for about } 1.3 \text { million insured workers } \\
\text { from factories and workshops that } \\
\text { are temporarily suspended for health } \\
\text { inspections } \\
\text { - Fiscal support measures for Ministry of } \\
\text { Health and Sports for additional health- } \\
\text { related expenditures. } \\
\text { - SMEs, hotels and tourism sectors } \\
\text { are receiving support with a capital } \\
\text { of MMK } 100 \text { billion, composed of } \\
\text { MMK } 50 \text { billion from the national } \\
\text { Revolving Fund approved by the Union } \\
\text { Government and MMK } 50 \text { billion from } \\
\text { the Social Security Fund. }\end{array}$ & $\begin{array}{l}\text { - Cuts in policy interest rate by } \\
0.5 \text { percentage points on } 12 \text { March and } \\
\text { by } 1 \text { percentage point on } 24 \text { March, } \\
\text { followed by a further reduction of } \\
1.5 \text { percentage points effective on the } \\
1 \text { st of May. } \\
\text { - Deposit rates will be subject to a lower } \\
\text { minimum rate of } 6.5 \% \text {, secured lending } \\
\text { rates will be lowered to a maximum of } \\
11.5 \% \text {, while unsecured lending will } \\
\text { be subject to a lower maximum rate of } \\
14.5 \% \text {. } \\
\text { - Deposit auctions have been halted } \\
\text { to maintain adequate liquidity in the } \\
\text { interbank market. }\end{array}$ & $\begin{array}{l}\text { - Central Bank of Myanmar, https://www. } \\
\text { - cbm.gov.mm//content/3912 } \\
\text { CSIS, https://www.csis.org/programs/ } \\
\text { southeast-asia-program/southeast-asia- } \\
\text { - } \begin{array}{c}\text { covid-19-tracker-0\#ASEAN } \\
\text { ADB, https://covid19policy.adb.org/ } \\
\text { policy-measures/MYA }\end{array}\end{array}$ \\
\hline \multicolumn{4}{|c|}{ China and India } \\
\hline China & $\begin{array}{l}\text { - Initial package of CNY } 3.6 \text { trillion of } \\
\text { fiscal measures or financing plans } \\
\text { to support spending on epidemic } \\
\text { prevention and control, production } \\
\text { of medical equipment, accelerated } \\
\text { disbursement of unemployment } \\
\text { insurance and its extension to migrant } \\
\text { workers, tax relief and waived social } \\
\text { security contributions. } \\
\text { - Measures to ease SME liquidity } \\
\text { constraints. } \\
\text { - VAT exemption for small-scale taxpayers } \\
\text { in Hubei province, and reduction from } \\
\text { 3\% to } 1 \% \text { for those in other provinces. } \\
\text { - Lowered/exempted employers' } \\
\text { contributions to social insurance. } \\
\text { - Tariff exemption on imported supplies } \\
\text { for COVID-19 control. } \\
\text { - Additional stimulus response estimated } \\
\text { at CNY } 4 \text { trillion on } 28 \text { May to further } \\
\text { support employment and jobs, and to } \\
\text { provide assistance to factories and hard-hit } \\
\text { companies. }\end{array}$ & $\begin{array}{l}\text { - Reduction in policy rates, from } 4.15 \% \text { in } \\
\text { February to } 4.05 \% \text { in March and } 3.85 \% \\
\text { in April. } \\
\text { - Liquidity injection into the banking } \\
\text { system via medium-term lending facility, } \\
\text { up to a total of CNY } 1 \text { trillion since } \\
\text { January } 2020 \text {. } \\
\text { - Reduction of the } 7 \text {-day and } 14 \text {-day } \\
\text { reverse repo rates by } 30 \text { and } 10 \text { basis } \\
\text { points (bps), respectively. } \\
\text { - Cuts in reserve requirement ratio by } \\
50-100 \text { bps. } \\
\text { - Reduction of the interest on excess } \\
\text { reserves from } 72 \text { to } 35 \text { bps. } \\
\text { - Reduction of the one-year interest } \\
\text { rate charged by the People's Bank of } \\
\text { China (PBoC) on lending to financial } \\
\text { institutions that take deposits, called } \\
\text { the re-lending rate, by } 0.25 \text { percentage } \\
\text { points to } 2.25 \% \text {, aimed especially at } \\
\text { increasing cheaper credit for agricultural } \\
\text { and small firms. }\end{array}$ & $\begin{array}{l}\text { - People's Bank of China, http://www.pbc. } \\
\text { gov.cn/en/3688110/3688181/4026459/ } \\
\text { index.html } \\
\text { - People's Bank of China, http://wwww.pbc. } \\
\text { gov.cn/en/3688110/3688172/4028850/ } \\
\text { index.html } \\
\text { - BIS, https://www.bis.org/statistics/ } \\
\text { - } \frac{\text { kbpol.htm }}{\text { KPMG, https://home.kpmg/xx/en/home/ }} \\
\text { insights/2020/04/china-government- } \\
\text { and-institution-measures-in-response- } \\
\text { - } \begin{array}{l}\text { to-covid.html } \\
\text { South China Morning Post, https://www. }\end{array} \\
\text { scmp.com/economy/china-economy/ } \\
\text { article/3086569/china-pledges-largest- } \\
\text { ever-economic-rescue-package-save- } \\
\text { - Aobs } \\
\text { pDB, https://covid19policy.adb.org/ } \\
\text { policy-measures/PRC }\end{array}$ \\
\hline
\end{tabular}




\begin{tabular}{|c|c|c|c|}
\hline & $\begin{array}{c}\text { Fiscal policy measures } \\
\text { (including income support schemes) }\end{array}$ & Monetary policy measures & Data sources \\
\hline India & $\begin{array}{l}\text { - Three direct support measures, } \\
\text { estimated at USD } 142.6 \text { billion out of } \\
\text { a government support package worth } \\
\text { USD } 266 \text { billion, covering health } \\
\text { (INR } 150 \text { billion), non-health initiatives } \\
\text { (around INR } 2 \text { trillion) and fiscal support } \\
\text { (USD } 112.50 \text { billion). } \\
\text { - Package includes health infrastructure } \\
\text { such as COVID-19 testing facilities, } \\
\text { personal protective equipment, isolation } \\
\text { beds, intensive care unit beds and } \\
\text { ventilators. } \\
\text { - Other key elements are in-kind (food, } \\
\text { cooking gas) and cash transfers to } \\
\text { lower-income households; insurance } \\
\text { coverage for healthcare workers; and } \\
\text { wage support for low-wage workers, } \\
\text { including eased criteria for benefits in } \\
\text { the event of job loss. } \\
\text { - Measures to ease tax compliance } \\
\text { across a range of sectors, including } \\
\text { postponement of filing and other } \\
\text { compliance deadlines. } \\
\text { - Measures by state governments to } \\
\text { support the health and well-being of } \\
\text { lower-income households, primarily } \\
\text { in the form of direct transfers. The } \\
\text { magnitude varies by state. }\end{array}$ & $\begin{array}{l}\text { - Repo and reverse repo rates reduced on } \\
27 \text { March by } 75 \text { and } 90 \text { bps to } 4.4 \% \text { and } \\
4.0 \% \text {, respectively. Liquidity measures } \\
\text { worth INR } 3.7 \text { trillion covering Long } \\
\text { Term Repo Operations, a cash reserve } \\
\text { ratio cut of } 100 \text { bps and an increase in } \\
\text { marginal standing facility to } 3 \% \text { of the } \\
\text { Statutory Liquidity Ratio. } \\
\text { - Open market operations and special } \\
\text { refinance facilities for rural banks, } \\
\text { housing finance companies and small } \\
\text { enterprises. }\end{array}$ & 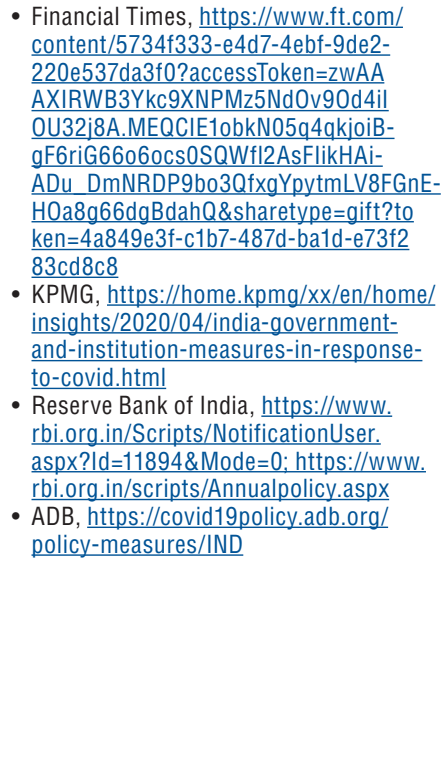 \\
\hline
\end{tabular}

Notes $:$ BIS $=$ Bank for International Settlements; BOT $=$ Bank of Thailand; BSP = Bangko Sentral ng Pilipinas; CSIS = Center for Strategic and International Studies; IMF = International Monetary Fund; KPMG = Klynveld Peat Marwick Goerdeler; MAS $=$ Monetary Authority of Singapore; PBoC = People's Bank of China.

Figures above do not include foreign borrowings and loans. Some figures and policy measures may change following new developments in the countries. Currency conversions used are based on OECD exchange rates (https://data.oecd.org/ conversion/exchange-rates.htm). 


\section{Chapter 2}

\section{Policy priorities in response to COVID-19 in Emerging Asia}

This chapter presents policy priorities for coping with the social and economic impact of COVID-19 in Emerging Asia. It describes how the crisis has transformed the use of digital tools and the opportunity this presents for the region's tech sector. The chapter outlines the region's efforts to deal with the pandemic's devastating effects on travel and tourism. It examines in detail the health aspect of the crisis, including regional and international efforts to redress shortages of medical staff, healthcare facilities and supplies. The chapter also describes how region-wide initiatives for fighting the pandemic strengthened after a slow start. In all of these areas, it provides suggestions for forward-looking policies to be put in place in case of future outbreaks. 


\section{Introduction}

Timely and effective policy responses are necessary to deal with the economic and social impact of the COVID-19 pandemic. All countries in Emerging Asia have implemented measures to ease the economic shock, including stimulus packages. However, lessons learned as the pandemic swept the region and the world indicate the need for more broad-based economic policies to hold up growth. This chapter examines policy priorities for coping with the pandemic's impact in Emerging Asia. The crisis demonstrated the importance of digitalisation, which became imperative during confinement to guarantee the continuity of essential services. Looking forward, policy makers need to maximise the use of digital tools, while at the same time ensuring cyber resilience. In the tourism sector, which was badly affected, emergency support measures need to be supplemented with a more holistic longerterm strategy. The health sector needs policies not only to curb the spread of the virus, but also to prepare healthcare systems for potential future outbreaks. Regional initiatives to deal with the pandemic and its effects are currently underway and need to be strengthened.

\section{Surging demand for digital tools creates an opportunity for Emerging Asia}

The COVID-19 crisis will negatively impact almost the entire commercial sphere in 2020. However, it will also lead to lasting transformations that should benefit certain sectors, starting with technology and firms that enable online and technology-based services (Box 2.1). Indeed, the health crisis pushed employees, households, businesses and students into a digital world. Digitalisation allowed telework and online platform applications to proliferate while people were confined to their homes. Demand for digital work and non-professional applications ramped up as lockdown measures took effect globally. These include apps to assist business continuity and online learning, and to provide households with alternative solutions, including online transactions more generally. New telemedicine online platforms were also introduced.

\section{Box 2.1. Tech businesses emerge as winners during the COVID-19 period}

The use of online services for virtual meetings and teaching increased sharply during the COVID-19 crisis and could become the new norm over time. This will boost demand for ADSL connections, semiconductors, connectivity, software and social networks. The video conferencing technology firm Zoom Video Communications Inc. is one of the major winners in this field. The US software firm derives approximately $8 \%$ of its global revenues in the Asia-Pacific region, according to Zoom's March 2020 filing. The company has seen its stock price soar by more than 126\% since the beginning of 2020 . Tech firms in Emerging Asia could take advantage of this expanding market. China's Tencent Holdings Ltd. recently rolled out Tencent Meeting, a global video conferencing tool. It amassed more than 10 million daily active users in China between December 2019 and January 2020, according to its March 18 earnings release. The stock price of Tencent Holdings Ltd. has risen by nearly 42\% year-to-date as of 22 July 2020.

Driven by containment measures to curb the spread of the virus all over the world, the gaming industry also saw record-breaking figures. From 16 to 22 March 2020, for example, 2.74 million video games were downloaded in EMEAA (Europe, Middle East, Asia and Africa), an increase of $52.9 \%$ over the previous week, according to the specialised site GamesIndustry.biz. Although two new games were released in that period, the phenomenon is linked to COVID-19 lockdown measures. In addition to the rise of the market for console and PC games, mobile games also reached historic levels. According to the App Annie market observatory, weekly mobile game downloads 
Box 2.1. Tech businesses emerge as winners during the COVID-19 period (cont.)

increased by $30 \%$ in March 2020, compared to the entire fourth quarter of 2019 (App Annie, 2020). According to the same source, India was one of the largest markets in terms of game downloads on Google Play, while China was the largest market in terms of consumer spending on iOS. Average weekly game downloads in China rocketed by $80 \%$ in February 2020 compared to the same period in 2019, with consumer spending up by 15\% from Q4 2019.

E-commerce was another winner. In the week of 22 March 2020, weekly downloads for shopping applications in Thailand increased by $60 \%$, according to App Annie, as cited by S\&P Global Market Intelligence, while Indonesia, Singapore and Viet Nam each recorded a $10 \%$ increase in weekly downloads. Lazada Group SA, one of Southeast Asia's largest online platforms, announced that its "See-Now-Buy-Now" livestreaming feature recorded an active audience of more than 27 million across Southeast Asia in April 2020, and that the gross value of merchandise generated increased by $45 \%$ month-on-month. E-grocery is a segment of e-commerce that could experience considerable growth in the post-crisis period. Lazada Group opened a virtual store in Malaysia to link farmers with consumers, who bought 1.5 tonnes of vegetables a day on average (Bloomberg, 2020a). Lazada has opened new grocery outlets in Indonesia, Malaysia and Viet Nam since the start of the pandemic, expanding from the Philippines, Singapore and Thailand.

Food delivery services are not new in Southeast Asia, but their reach broadened during the crisis, supported by mobile phone applications and the use of smartphones. With restaurants banned from serving food on their premises, one of the largest players in Southeast Asia, the ride-hailing service provider Grab enjoyed a surge in orders. Its Indonesian arm, Grab Indonesia, reported a 22\% and 21.5\% increase in GrabMart and GrabExpress orders, respectively, from February to March 2020. With corporate funding conditions showing signs of tightening, a number of companies in the food delivery segment secured financing from local venture-capital and angel investors. An example is Indonesia's ride-hailing and food delivery firm GoJek, which raised USD 1.2 billion in March 2020, one of the largest funding deals to emerge since the COVID-19 outbreak in January (Bloomberg, 2020b). Another example is CloudEats, a cloud kitchen start-up based in the Philippines. CloudEats announced in April that it had raised USD 1.4 million in a seed-financing round, enabling the company to finance its expansion across the Philippines and Southeast Asia (Tech in Asia, 2020).

Traditional supermarket chains also saw a rise in sales as customers rushed to stock up on food, cleaning products and hand sanitiser in April. In countries where geography complicates online deliveries, such as the Philippines, brick-and-mortar supermarket chains remained consumers' preferred choice. Robinsons Retail Holdings, owner of one of the largest supermarket chains in the Philippines, reported a $45 \%$ increase in net income in Q1 2020.

\section{Video conferencing expands dramatically to counteract economic disruption}

A massive increase in video conferencing is one of the most notable results of the pandemic. This technology proved to be the ultimate solution for remotely connecting people during the lockdown. The surge in demand for online communication apps in Asia and across the world was met by Zoom, Webex, Cisco, Microsoft Teams and BlueJeans among other tech firms. Zoom in particular saw a huge growth in demand in the first quarter of 2020 and in Emerging Asia, China, India, Indonesia and Viet Nam saw a spike in Zoom downloads. India recorded the largest number, with nearly 6 million downloads compared to 0.1 million prior to the onset of COVID-19 (Figure 2.1). Daily users of Zoom 
expanded in India from 10 million to more than 300 million between March and May. This accelerated uptake was driven by a young and increasingly tech-savvy workforce, as reflected in significant growth in e-commerce in the country. Growth in Zoom downloads was also strong in Indonesia, with 2.3 million installations in March. In China and Viet Nam, Zoom downloads and usage peaked in February before slowing in March.

\section{Figure 2.1. Zoom downloads, Q4 2019 to Q1 2020}

Millions

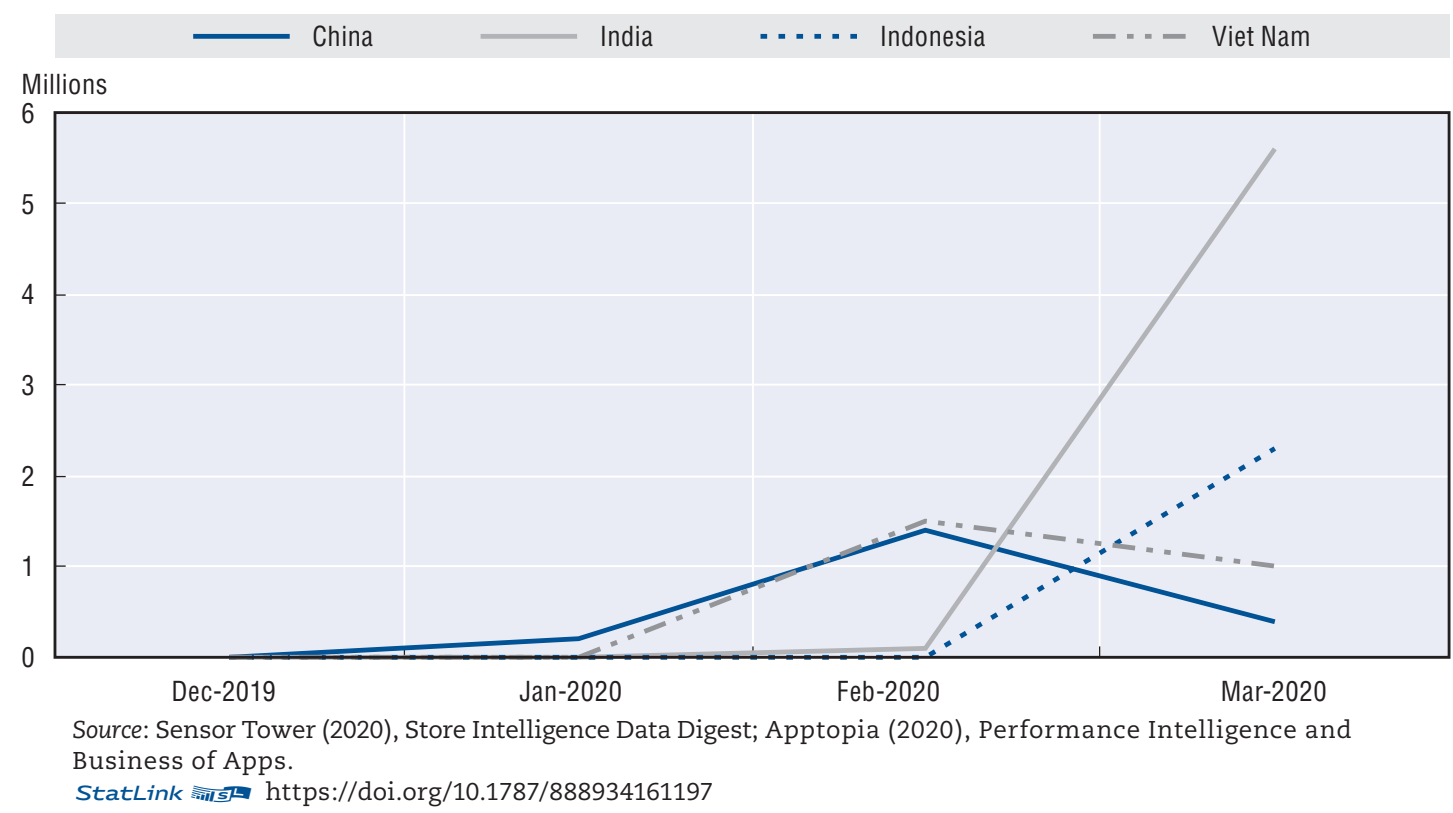

Telework expanded as most Emerging Asian countries took action to slow the spread of the virus. Under a lockdown order issued in Lao People's Democratic Republic (hereafter "Lao PDR") on 29 March, for example, all government officials were required to work from home. In Indonesia, the government encouraged companies to adopt work-from-home arrangements, and some employees over the age of 50 at state-owned enterprises were asked to work from home beginning in mid-March. However, telework was complicated in some countries by inadequate Internet access and speed.

\section{People seek pandemic information and medical help online}

The coronavirus crisis also demonstrated the need to increase healthcare spending, and this will benefit corporations in the biotechnology and medical equipment sectors, as well as pharmaceutical groups. Traditional healthcare is being revolutionised by technology, with robots and other high-tech tools deployed to evaluate patients' conditions and monitor the spread of the virus. According to Tencent Holdings' March 2020 earnings release, more than 300 million users consulted Tencent Health to access real-time COVID-19 data and for online consultation and artificial intelligence-powered self-diagnosis services. In India, the global pharmaceutical company Cipla Limited launched a toll-free helpline to assist patients in procuring medication from pharmacies. It also launched webinars to keep the medical community informed about COVID-19 developments (Cipla, 2020). Cipla's stock price has increased by nearly $39 \%$ in July compared to January 2020. Other Southeast Asian firms operating in the healthcare sector have seen increased investor demand for their shares. For example, the share price of Malaysian LYC Healthcare Berhad has added 13.3\% year-to-date as of 22 July 2020, highlighting the solid growth prospects for the sector. 


\section{Box 2.2. COVID-19 and the digital medical industry in China}

The use of online medical apps increased sharply during the pandemic, with people relying on these applications for information about the coronavirus outbreak and methods for preventing the disease. This helped to expand awareness about COVID-19, especially regarding the extent of transmission and the progress of its spread. The surge was particularly notable in China, where the medical apps Ding Dang and Jin Ke Online were extensively used (Table 2.1).

Table 2.1. Use of online medical apps in China during the pandemic

\begin{tabular}{|c|c|c|}
\hline Medical apps & 2020 daily active users ${ }^{*}$ (million) & Year-on-year growth (\%) \\
\hline Ding Xiang Yuan & 0.3 & $222.2 \%$ \\
\hline Assistance of Medicine & 0.2 & $108.1 \%$ \\
\hline Ding Dang & 0.16 & $952.6 \%$ \\
\hline Jian Ke Online & 0.12 & $306.8 \%$ \\
\hline
\end{tabular}

Note: ${ }^{*}$ Number of online users during spring festivals in 2020.

Source: QuestMobile TRUTHChina Mobile Internet Database, https://www.questmobile.com.cn/en.

With the continuous spread of COVID-19, more digital medical platforms have been built globally. Ali Health, We Doctor, Bai Du Health, and Jing Dong Health were popular during the outbreak. These platforms provide not only medical information, but also psychological comfort. Among them, WeDoctor has four versions, in Chinese, English, Italian and French.

\section{Online learning flourishes during the lockdown}

The closing of schools and educational institutions around the world sparked increased use of online learning tools to allow continuity of education while children and educators were confined to their homes. In China, the usage of online education platforms increased by $22 \%$ during the outbreak compared to the same period in the previous year, and people spent $30 \%$ more time using these digital platforms. The use of online digital platforms by the education industry jumped 17.5\% y-o-y, a larger increase than for the online shopping and video industry.

In Lao PDR, Laos Asia Pacific Satellite Co. Ltd and the Ministry of Education designed an online education platform in March 2020. The Laos Education Channel officially started providing remote video learning services for college students in May. Cambodia also launched online classes via television and the Internet. In India, certain online education companies began providing their learning platforms to students free of charge. For example, the online education corporation Unacademy shared its technology, and viewing of its free live-streaming classes increased dramatically. Other Indian educational and scientific corporations also saw a considerable increase in users, with newly registered students growing by $60 \%$ for Byju's, doubling at Topper and increasing ten times at Veduantu after the COVID-19 outbreak. Indonesia's Ministry of Culture and Education, meanwhile, created a Learn At Home television programme for students of all levels, with online tutoring through Learn at Home ambassadors to allow students to consult teachers of each course online.

However, limited technological capacity can hinder the use of digital tools for education and other purposes, and the problem is likely to continue in emerging economies with limited information technology infrastructure and Internet availability. According to World Bank data for 2017, Internet usage in the CLM region (Cambodia, Lao PDR and 
Myanmar) was among the lowest in the world. In Myanmar, the development of Internet infrastructure is hampered by frequent power cuts. The World Bank lists the power supply gap as a deterrent to Myanmar's economic growth and has encouraged the local authorities to double the size of investment in the power supply and to triple the pace of project development (World Bank, 2019a). Affordability of online services is another issue confronting ASEAN countries. In India, online education infrastructure remains weak, with large-scale remote education mainly supported by radio and TV. Eupheus Learning, a company based in New Delhi, launched live video teaching, but found it challenging to start the online teaching due to the difficulty of simulating offline teaching activities through the Internet. To meet increased demand for digital learning, improved Internet access and digital education platforms are urgently needed.

\section{Cloud hosting and smart home technologies also experience growing demand}

COVID-19 resulted in increased demand for cloud-based business tools and services computing services, cloud database management and virtual servers - to sustain business functions while employees were working remotely. For example, the use of Google Docs and Dropbox increased markedly. Cloud-based services are used to adapt work and business functions to store, manage and process data that is usually accessible over the Internet. Emerging Asian economies recorded extraordinary growth in cloud hosting revenue from April 2019 to April 2020, with the largest year-on-year increases in China (47.1\%) and India (38.5\%). Software solutions and development applications have similarly seen an upturn in use. In particular, Indonesia and China posted positive year-on-year growth in software solutions revenue, at $15.7 \%$ and $14.6 \%$ respectively, while India and Viet Nam saw growth of less than $5 \%$ over the same span (Figure 2.2).

Figure 2.2. Rise in cloud hosting and software solutions revenue April 2019 to April 2020, percentage y-o-y

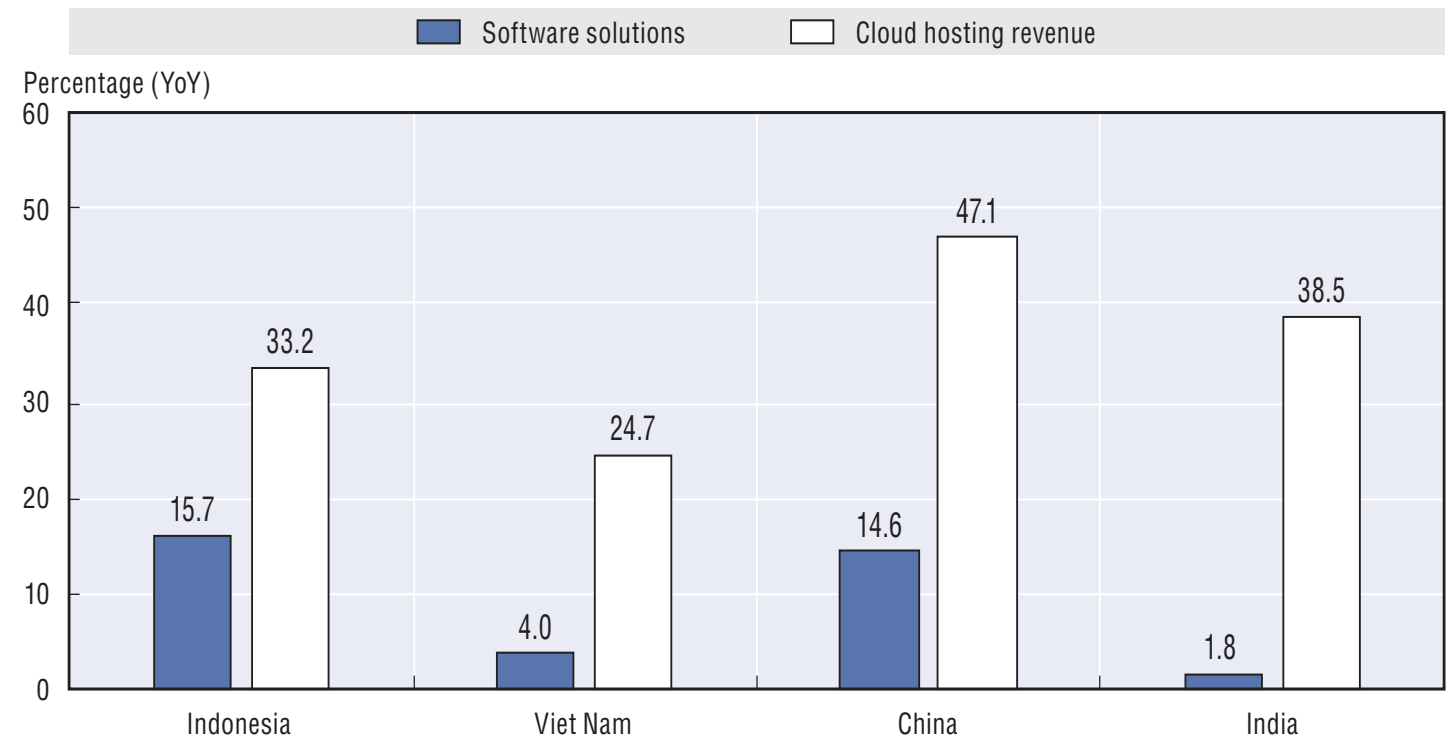

Note: The cloud hosting market represents third-party cloud service providers who deliver computing resources such as servers and storage over the Internet to their customers. This excludes dedicated single-purpose solutions such as ERP and CRM. Company examples include Amazon Web Services, Microsoft Azure, Google Cloud, and IBM. The software solutions market includes Productivity Software, Enterprise Software, as well as System Infrastructure Software and Application Development Software. The majority of software solutions in these market segments are designed to be used in a professional environment, but may also be used privately. Company examples include Microsoft, Citrix, SAP, and Adobe.

Source: Statista.

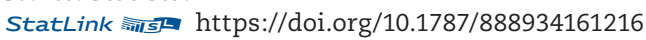


Along similar lines, smart home technologies have grown in response to health insecurity and stay-at-home orders. Other than Singapore, which established home automation prior to COVID-19, all emerging countries posted significant growth in smart home users in April 2020 y-o-y, particularly in the Philippines (60.0\%), Cambodia (58.5\%), Lao PDR (59.8\%) and Myanmar (61.3\%) (Figure 2.3).

Figure 2.3. Increase in use of smart home technologies

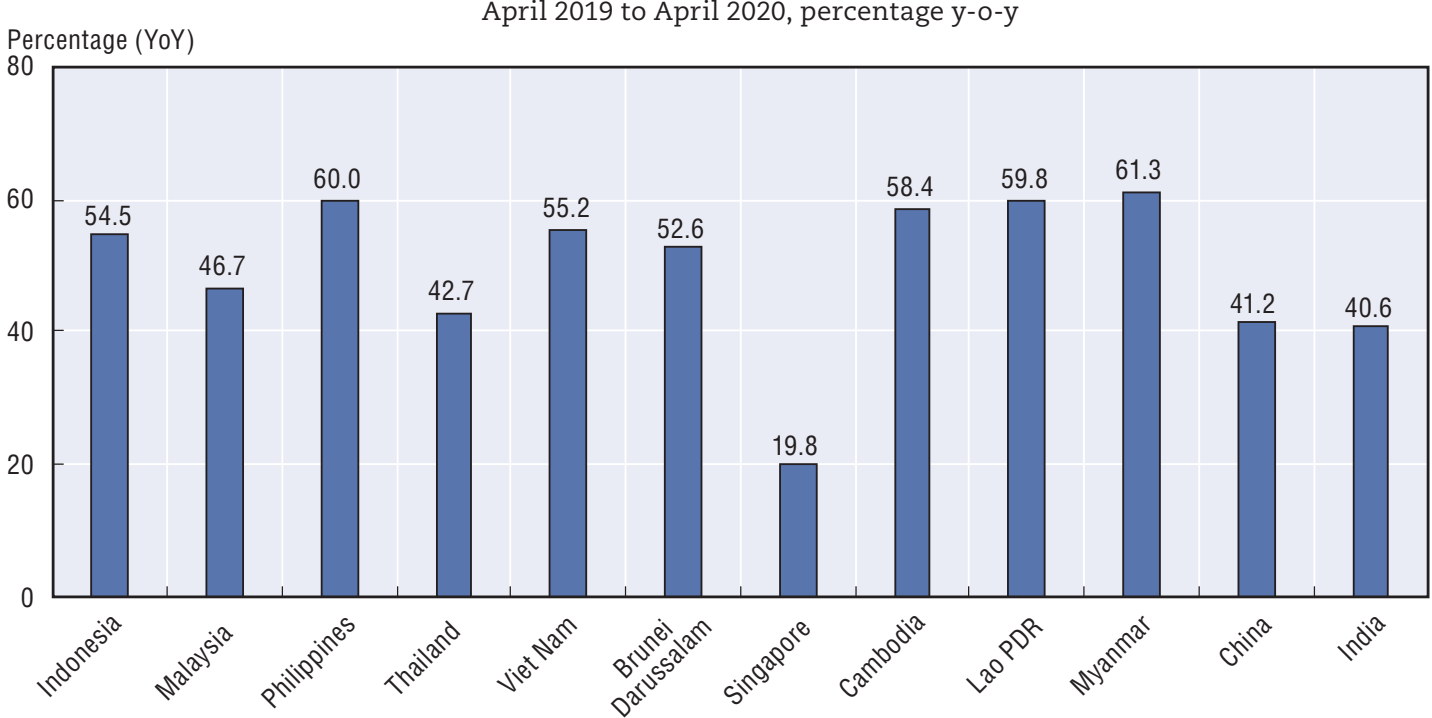

Note: Smart home solutions include connected devices and related services that enable home automation for private end users (B2C). These devices are connected directly or indirectly via a so-called gateway to the Internet. They include digitally connected and controlled devices within a house that can be remote controlled sensors, actuators and cloud services that support automation in any way, control hubs to connect sensors and actuators with remote controls and to each other, $\mathrm{B} 2 \mathrm{C}$ hardware and software sales, as well as subscription fees.

Source: Statista; Omdia (2020), Application Market Forecast Tool.

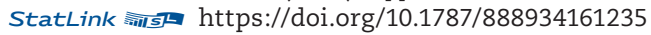

\section{Use of e-commerce and e-banking accelerate during pandemic}

Online transactions via various payment methods (credit cards, PayPal, AliPay, etc.) have seen a recent surge in both revenue and users. Among Emerging Asian economies, Cambodia, Lao PDR and Myanmar posted annual growth of $20 \%$ in e-commerce users in April 2020 compared to the previous year (Figure 2.4). In terms of transaction revenue, higher growth in digital commerce sales and revenue were recorded in China (24.9\%), Indonesia (24.4\%) and India (23.2\%) (Box 2.3). Acceleration in the uptake and use of digital payments also occurred in Malaysia, the Philippines, Thailand, Viet Nam, Singapore and Cambodia, well ahead of Brunei Darussalam, Lao PDR and Myanmar (Figure 2.5). Two big drivers of digital commerce are the emergence of smartphones and the fast growth of the Internet-connected population. 
Figure 2.4. Rise in e-commerce users

April 2019 to April 2020, percentage y-o-y

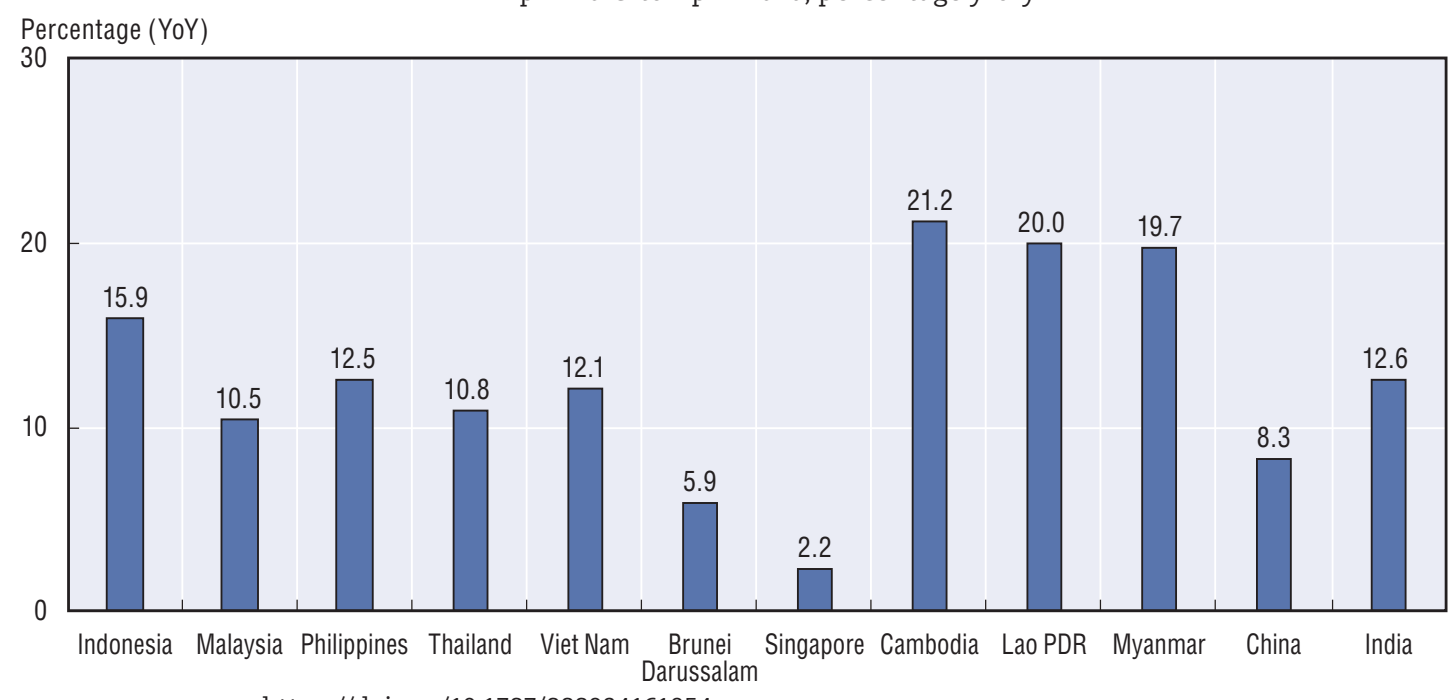

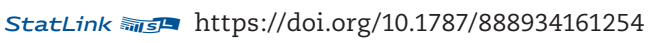

Figure 2.5. Increase in digital commerce

April 2019 to April 2020, percentage y-o-y

Percentage (YoY)

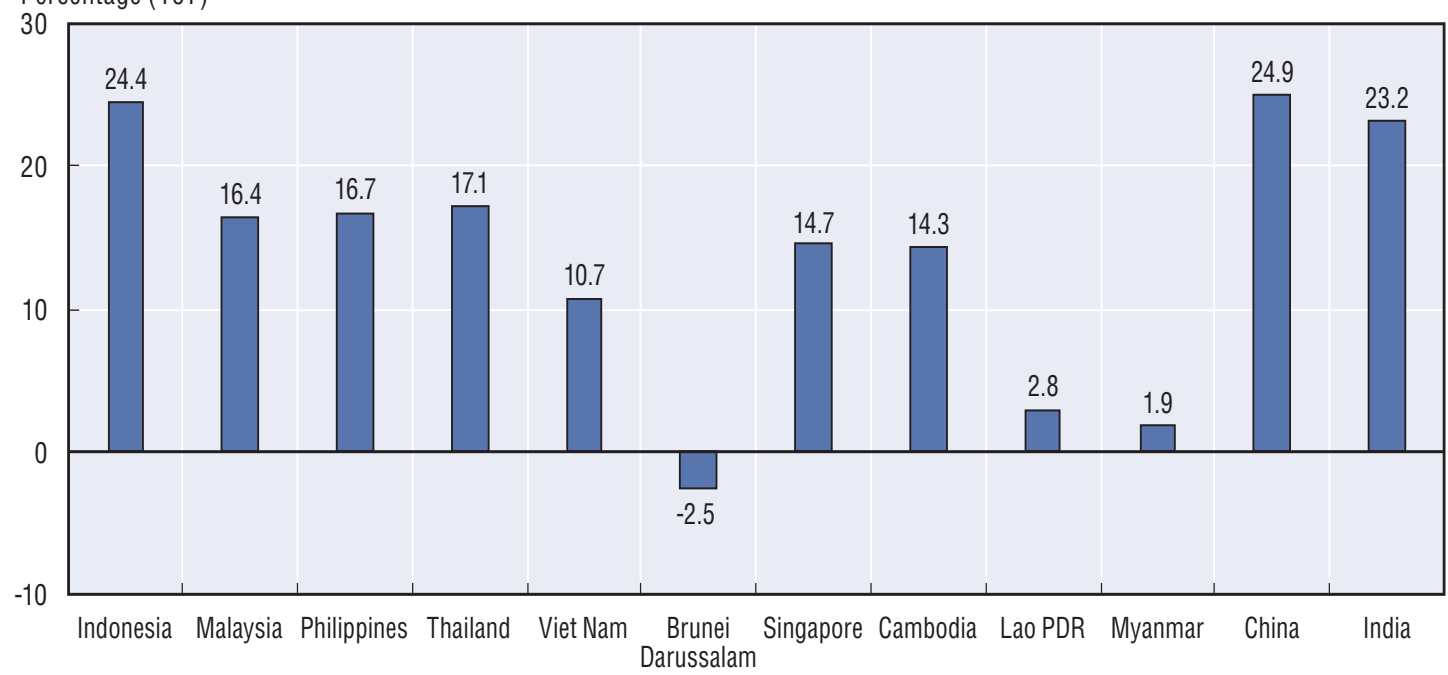

Note: The digital commerce segment covers all consumer transactions made via the Internet that are directly related to online shopping for products and services. Online transactions can be made via various payment methods (credit cards, direct debit, invoice or online payment providers, such as PayPal and AliPay). Transactions that are exclusively between businesses (Business-to-Business) or private individuals (Peer-to-Peer) are not included in this segment; online payments not relating to the purchase of goods or services that trigger a bank transfer are also not included.

Source: Statista.

StatLink 解每 https://doi.org/10.1787/888934161273

\section{Box 2.3. E-commerce for fresh food expands in China}

The use of e-commerce is traditionally high in China during the Spring Festival as people return to their home towns and celebrate with their families. This year, the pandemic coincided with the Spring Festival, and daily active users of overall mobile shopping 


\section{Box 2.3. E-commerce for fresh food expands in China (cont.)}

decreased, from 426 million before the festival to 337 million during the festival period (24 January to 2 February). However, the daily time spent shopping for fresh food via e-commerce increased by $20 \%$ during the festival, and the average number of daily active users increased by nearly $30 \%$ and continued to grow afterwards, with leading fresh food businesses such as Hema, Ding Dong and Daily Fresh achieving rapid growth (Figure 2.6). Use of these apps during the month after the festival increased y-o-y by $123.4 \%, 325.9 \%$ and $105.1 \%$ respectively.

\section{Figure 2.6. Rise in use of fresh food e-commerce apps in China} Active users, thousand people

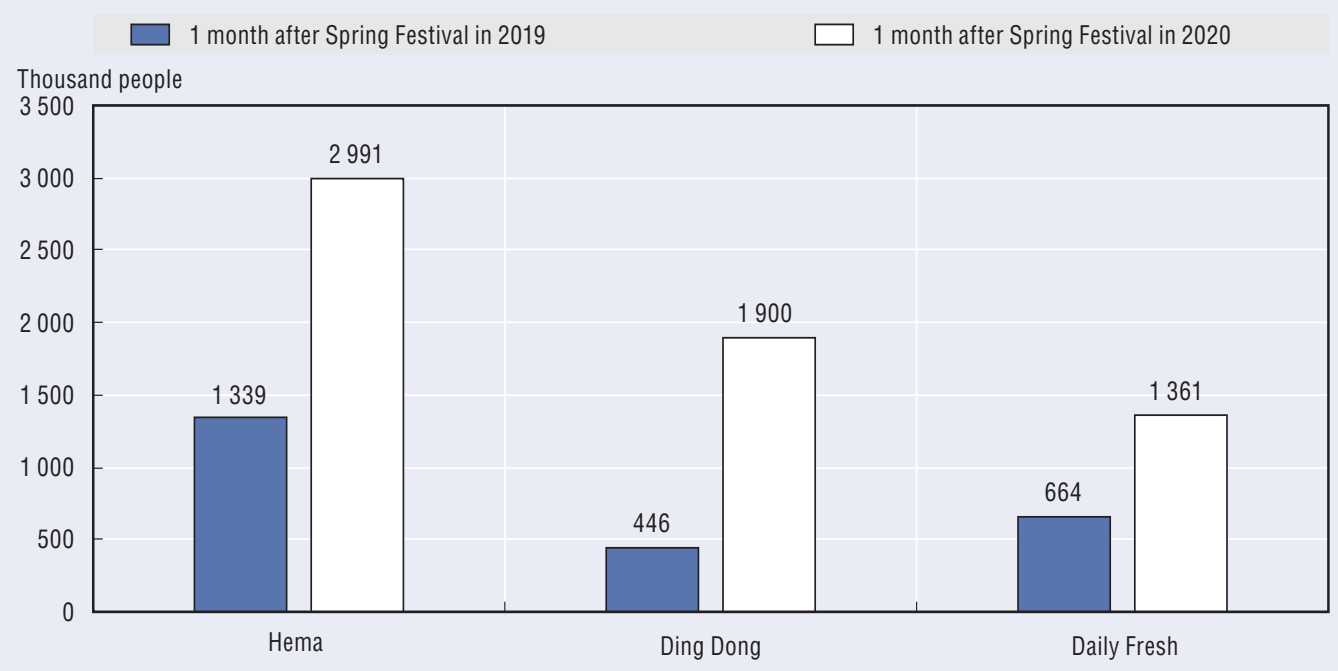

Note: Definition of time period: 1 month after Spring Festival holiday in 2019 refers to 11 February-11 March 2019; and 1 month after Spring Festival holiday in 2020 refers to 3 February-3 March 2020.

Source: QuestMobile TRUTH China Mobile Internet Database.

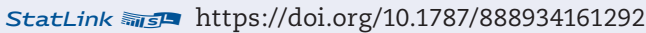

The pandemic also brought about an increase in e-banking as banks encouraged customers to conduct transactions electronically to reduce the risk of transmitting the virus. For example, the volume of e-banking transactions in Viet Nam rose by $26 \%$. In the Philippines, lockdown measures also resulted in a sharp increase in registrations for Internet banking service. A comparison of transaction statistics in March 2020 before and after the lockdown shows that the transaction value of digital banks soared by $633 \%$ and transactions rocketed by $416 \%$.

Thailand supported the use of online payments during lockdown by allowing people to apply for 10 GB of free Internet service as of April 2020. In addition, banks strongly recommended that customers link their personal bank accounts and mobile phone numbers to PROMPTPAY's official online payment to reduce the use of cash. In Singapore, financial institutions took measures to encourage all customers to adopt e-payment solutions in financial transactions. So far, more than 2 million people have registered to use PayNow, a digital cross-bank transfer service, and more than 120000 local companies have adopted PayNow Corporate and the Singapore Quick Response Code (SGQR) as e-payment solutions. In Malaysia, the Ministry of Communications and Multimedia and the Malaysian Digital Economy Corporation were providing about USD 138 million in 
free Internet service, and the country planned to invest an additional USD 92 million to increase network coverage and capabilities.

\section{Emerging Asia needs strategies for ensuring cyber security}

With sharp growth in online activities, a cyber incident that blocks access to the Internet could disrupt business operations, online education and healthcare providers, as well as other public systems and networks. Such disruptions can be unintentional or planned. Several cyber attacks in connection with the COVID-19 pandemic were reported in April 2020. Taking advantage of increased app usage, hackers used malicious software to infect users in South and Southeast Asia with spyware capable of collecting sensitive information about the respective users (CSIS, 2020a). It is imperative for Emerging Asian economies to put in place strategies that allow firms, individuals and communities to continue operating normally in the event of cyber incidents and disruptions.

\section{Further facilitating digitalisation is crucial in the region}

Cloud computing, digital commerce, e-learning platforms, and medical and shopping apps presented opportunities for countries to make economic gains during the COVID-19 pandemic, and affordable smartphones and the rise of mobile Internet penetration led to momentum in e-commerce activities. However, efforts to mobilise digital innovations remain limited in some emerging countries, especially those with insufficient IT infrastructure and Internet availability. The points developed below indicate that further facilitating digitalisation and innovation in the region is crucial.

- Countries in the region have not yet achieved the full potential of digitalisation. There are various barriers to the growth of digital technology in the region. Internet connectivity is rather low, with approximately half of the ASEAN population still lacking Internet access. When available, Internet connectivity mostly takes place through mobile broadband rather than through higher-speed fixed broadband. With mobile download speeds below the global average, Viet Nam, Thailand, Myanmar, Malaysia, Lao PDR, Cambodia, Indonesia, the Philippines and India require additional efforts to improve download speeds. Viet Nam, India, Lao PDR, the Philippines, Cambodia, Indonesia and Myanmar also trail the global average for fixed broadband download speeds. Investment is needed to upgrade Internet infrastructure and to improve bandwith. To help cover large capital expenditures, public-private partnerships could be envisaged. For example, the University Community Next Generation Innovation Project (Gig.U), a group of more than 30 leading US research universities, has expanded access to fibre-optic Internet connections at universities and adjacent communities.

- Digital skills need strengthening in the region. Areas for improvement range from basic computer literacy to more advanced skills such as data analytics or programming. Increased awareness of digital opportunities could help firms, and micro, small and medium enterprises (MSMEs) in particular, to enhance productivity and increase their presence on global marketplaces. The adoption of digital tools is uneven across economic sectors, with manufacturing, mining (World Economic Forum, 2017) and utilities (Booth et al., 2016) still in the early stages of digitalisation. 
Targeted strategies could be envisaged to assist the corporate sector at large, and lagging sectors in particular, to increase their digital footprint. For example, Singapore's e-Commerce Booster Package aims to support local retail businesses to expand their domestic reach, assist retailers seeking to expand overseas and strengthen retailers' digital marketing capabilities for e-commerce (Enterprise Singapore, 2020).

- Digital payment tools are underused. Contactless payment by card or mobile phone is a fast and relatively secure way to pay in local retail outlets. However, only $19 \%$ of bank account holders in Southeast Asia access their accounts through a mobile phone or the Internet (World Bank, 2019b). In order to encourage this payment method, digital payment tools should be made easier to use, the speed of online transfers improved and obstacles removed (e.g. barriers to small payments). Customers should be adequately informed, while merchants should be supported to acquire performant payment terminals. Customers' trust in the integrity of digital payment tools is essential. Fraud prevention mechanisms should be strengthened, in particular where authentication criteria for electronic payments and online transfers are still weak. Some initiatives in this regard are underway. For example, Brunei Darussalam unveiled a digital transformation strategy for 2019-25 with a focus on three areas: balancing regulation and innovation; adopting open digital payment; and increasing public awareness and education (Autoriti Monetari Brunei Darussalam, 2018).

- Deliveries of merchandise can be expensive and unreliable. This acts as a deterrent to the development of e-commerce, both domestically and internationally. The greatest barriers to logistics services in ASEAN have been identified as inefficient customs procedures and inspections, followed by obstacles in land transportation (de Souza et al., 2019). With e-commerce shipments facing unpredictable customs procedures in many countries, logistics bottlenecks within ASEAN are among the largest in the world (ASEAN, 2015). While these barriers contribute to protecting local enterprises from external competition, addressing them would support the development of e-commerce and provide consumers with a broader range of choices and more attractive prices.

\section{Travel and tourism suffer a major blow in global health crisis}

Travel and tourism were among the sectors worst impacted by COVID-19 in Emerging Asia. Travel restrictions were imposed in all countries in the region, though the scope, stringency and enforcement of these restrictions varied. Some ASEAN nations restricted travel from China in the early stages of the pandemic, and then quickly expanded the limits to travellers from other countries. Monthly visitor arrivals fell year-on-year beginning in March or earlier in ASEAN countries (Figure 2.7). The declines in visitor arrivals closely mirror countries' policy approaches in terms of regulating international flows, which have evolved from screening and/or temporary quarantine initially, to bans on all regions or even border closures as the health crisis unfolded (Figure 2.8). 
Figure 2.7. Visitor arrivals in selected Emerging Asian countries, 2018-20 Year-on-year percentage change

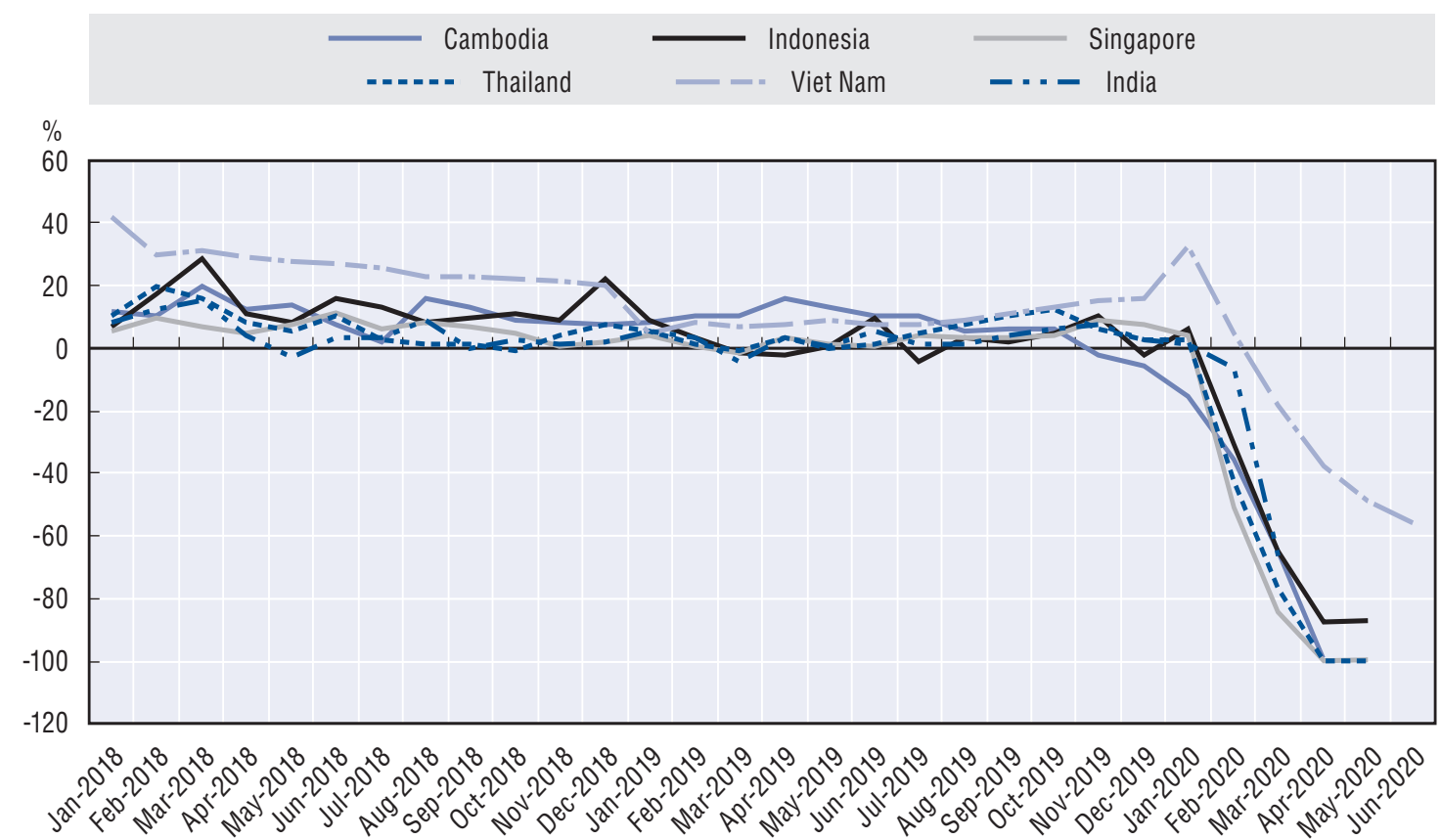

Note: The Thailand figures indicate international tourists only. The Viet Nam data is year-to-date.

Source: CEIC.

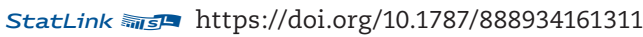

Figure 2.8. Visitor arrivals plummeted as restrictions on international travel tightened

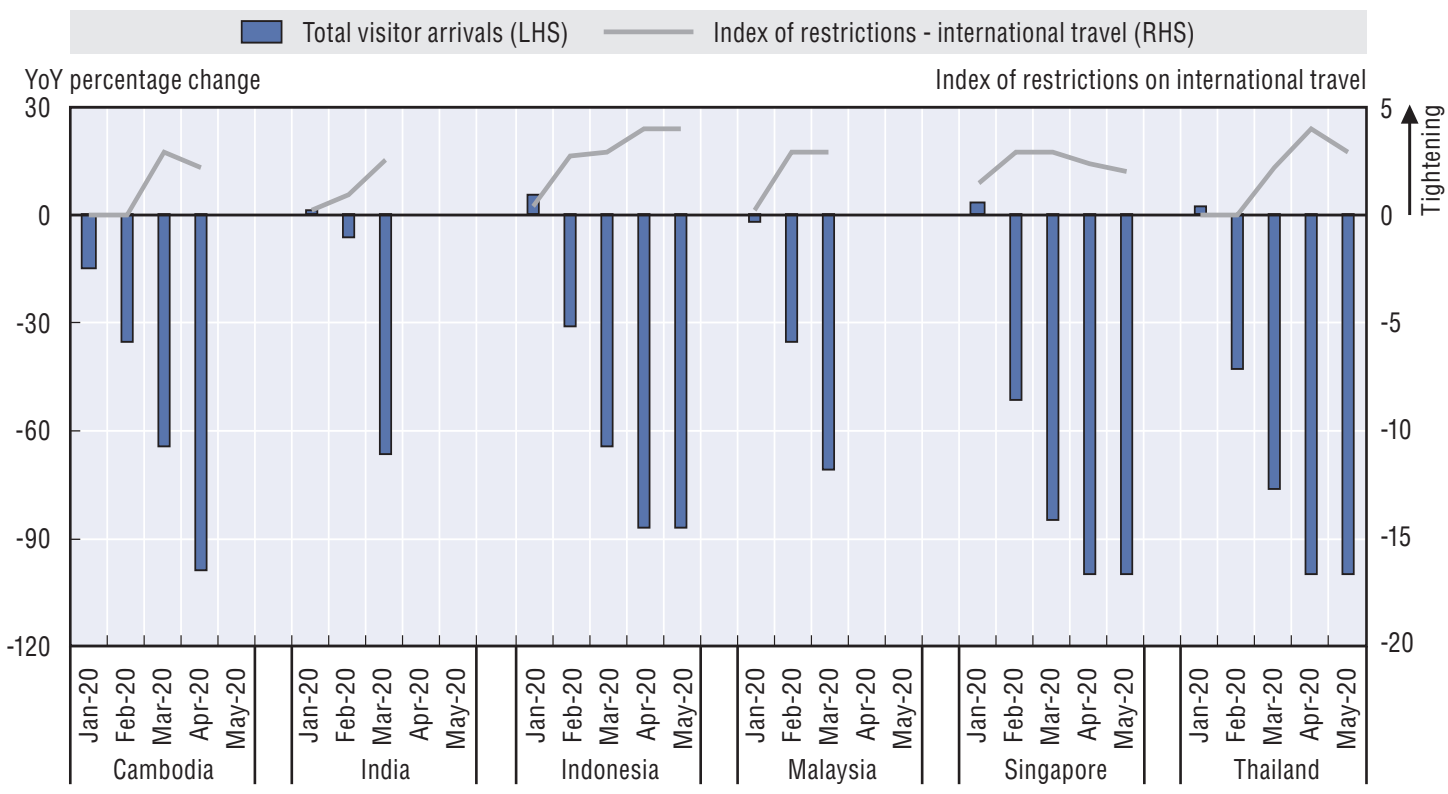

Note: The index of restrictions on international travel is defined on a scale between 0 and 4, as follows: 0 - no measures; 1 - screening; 2 - quarantine arrivals from high-risk regions; 3 - ban on arrivals from some regions; 4 - ban on all regions or total broder closure. The index is reported on a daily basis; the monthly value represents the average of daily values for the respective month.

Source: OECD Development Centre based on data from CEIC and Oxford COVID-19 Government Response Tracker.

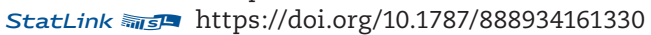


Travel restrictions also impacted airports. In the first quarter of 2020, airports in Emerging Asia reported the steepest year-on-year decline in passenger traffic over the last five years (Figure 2.9). Several major airlines (Air India, Cambodia Angkor Air and Royal Brunei Airlines, among others) reduced or cancelled flights in response to government restrictions and sagging demand.

Figure 2.9. Airport passenger traffic

Year-on-year percentage change, 2015-20

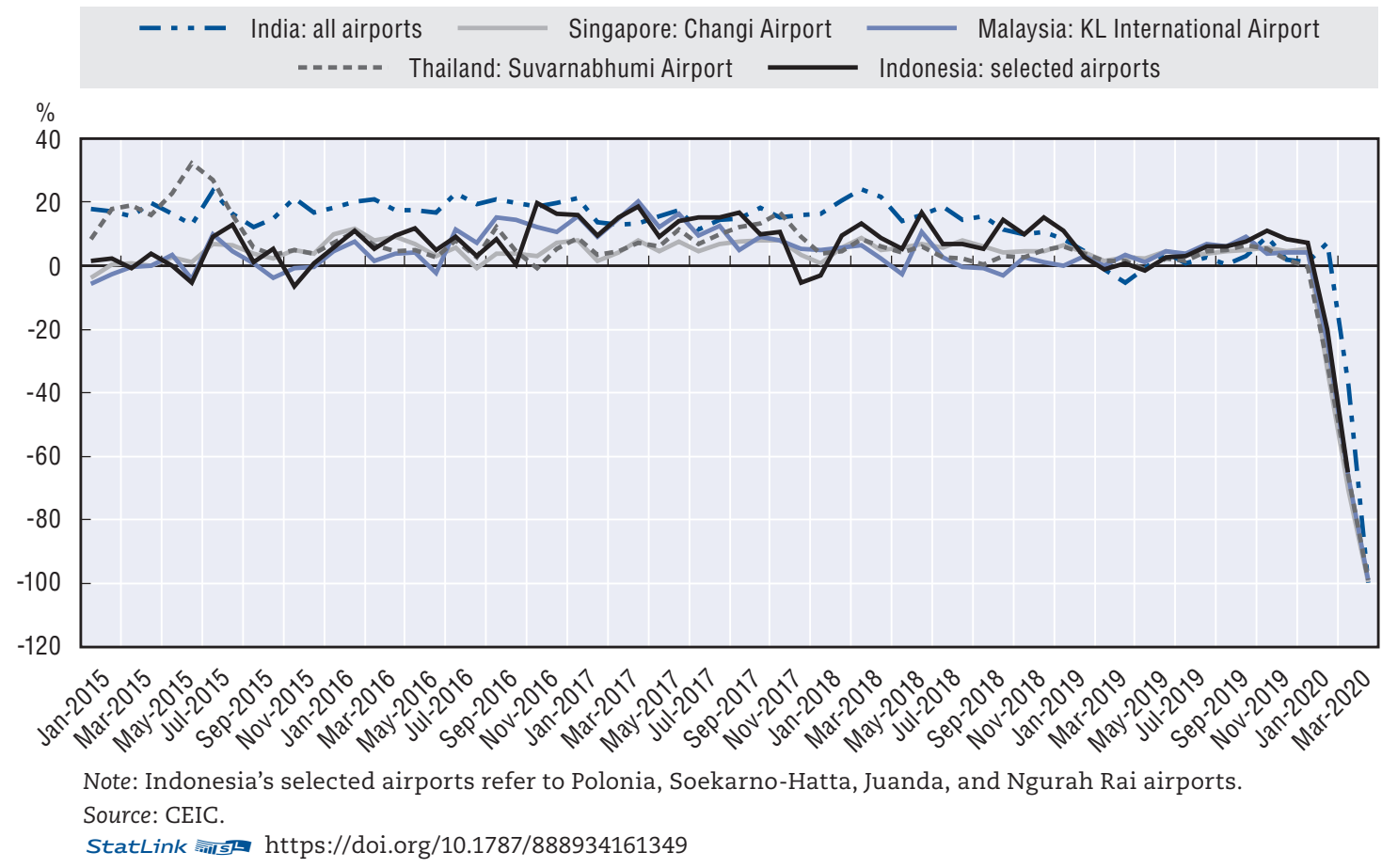

Declining passenger numbers created employment pressures for airlines. Workers at carriers in Lao PDR; the Philippines; and Hong Kong, China were laid off or placed on unpaid leave in response to suspension and cancellation of flights (Box 2.4).

\section{Box 2.4. Airlines struggle to cope with the pandemic}

Throughout the first and second quarters of 2020, airlines around the world downsized their workforces in an attempt to cut costs amid the pandemic. Pilots, cabin crew and maintenance and administrative staff were affected, mainly by temporary layoffs.

In Emerging Asia, Singapore Airlines reported on 23 March that it would reduce its capacity by $96 \%$ to cut costs, affecting around 10000 staff. In late February, Philippine Airlines announced layoffs of around 300 staff, while Cebu Pacific laid off more than 150 cabin crew in mid-March. Cathay Pacific reported in early February that it had asked around 27000 workers to take unpaid leave. Lao Airlines made a similar move in March. Cuts were even more drastic elsewhere. For example, British Airways suspended around 30000 staff in early April. Other airlines did not announce layoffs, but cut salaries instead. In the United Arab Emirates, Etihad Airways announced a temporary wage cut of $50 \%$ for its management and $25 \%$ for other staff in March. 


\section{Box 2.4. Airlines struggle to cope with the pandemic(cont.)}

Other factors also affected the air transport sector. The grounding of aircraft due to travel restrictions left more aircraft in airports than normal, increasing their exposure to the risk of typhoons and other weather damage. The loss of belly-hold cargo capacity - space in the belly of passenger aircraft used to transport cargo unrelated to the travelling passengers and crew - led to concerns regarding supply-chain disruptions as belly cargo accounts for $40 \%$ to $50 \%$ of airfreight, according to the International Air Transport Association (IATA). Declines in demand from certain manufacturing sectors were partially offset by increased demand for the transport of medical equipment. Some passenger airlines have resorted to cargo-only flights to generate revenue during the period of travel restrictions, but this has not been sufficient to cover the shortage.

Source: IATA (2020a), airline companies' press releases and news articles, as of 28 June 2020.

\section{Pandemic pummels travel for international meetings}

A sub-sector of tourism that has been heavily impacted by COVID-19 is meetings, incentives, conferences and exhibitions (MICE), which represents corporate or professional meetings held abroad, often in prime tourist destinations, including in Emerging Asia. These gatherings, which may mix business and leisure, are usually planned months or years in advance.

MICE tourism continues to face significant barriers as countries around the world begin to emerge from the pandemic (Grier, 2020). Restrictions on international travel may remain in place even as countries remove domestic restrictions on travel and economic activity (Financial Times, 2020). In Thailand for example, more than 8 million MICE travellers generated approximately THB 54 billion (Thai baht) in revenue in the second quarter of 2019, according to the Thailand Convention and Exhibition Bureau. The bureau projected that 37.8 million MICE travellers would generate THB 232 billion in the October 2019-September 2020 fiscal year. Unfortunately, a ban on incoming international flights from 26 April to 30 June will hurt the projected numbers (CAAT, 2020).

MICE events are typically large indoor gatherings, presenting a high risk of viral transmission; the sector thus needs to adapt (ICCA, 2020). This may involve caps on event sizes, increased use of remote conferencing and changes to activities and dining. MICE bookings will need to introduce flexible cancellation options due to the risk of future outbreaks of COVID-19 in destination or home countries.

A number of hotels in Thailand are pursuing certification to show they are "COVIDReady" in an attempt to attract both domestic and foreign tourists. Malaysia re-opened its entire tourism sector, including MICE, effective 1 July, with certain restrictions.

\section{Governments take steps to support tourism workers and boost domestic travel}

Several ASEAN countries implemented fiscal packages to support workers in travel and tourism during the period of restrictive measures. The packages primarily consist of payment exemptions or deferments (Brunei Darussalam, Indonesia, Lao PDR and Myanmar), debt restructuring (Cambodia) and cash aid to workers (IMF, 2020). Policies are crucially needed to protect vulnerable workers, many of whom are informal workers who lack access to insurance or relief schemes. Among ASEAN countries, informal employment accounts for anywhere from 20\% (Brunei Darussalam) to nearly 100\% of tourism employment (Cambodia) (ILO, 2020). Singapore is providing taxi and private car drivers with a package worth SGD 77 million (Singapore dollars), including SGD 45 million 
from the government. This package was further supplemented by an additional SGD 95 million from the government and SGD 25 million from taxi operators in March. In addition, the Singapore National Environment Agency announced on 18 February that it would provide a one-month rental waiver for stallholders in designated markets (Kit, 2020). Worker compensation is also needed for the reduction in demand for services and guarantees of income in the event of illness.

With many national borders closed, countries including Indonesia, Malaysia and Thailand have sought to stimulate domestic tourism to keep tourism-related businesses operating and workers employed. The government of Indonesia subsidised airfares to certain domestic tourism locations by up to 30\% in March, April and May (ILO, 2020; Jefriando and Suroyo, 2020). To compensate for the lost airline revenue, the country also lowered jet fuel prices and airport charges at relevant airports. Thailand intended to offer vouchers of THB 1000 towards out-of-province tourism packages for up to 5 million travellers, but cancelled the plan when it increased the stringency of its lockdown (ILO, 2020). The Malaysian government assisted airlines, resorts and hotels by providing discount vouchers valid from March, while offering MYR 1000 (Malaysian ringgit) in income-tax relief for expenses accrued at a destination registered with the Ministry of Tourism (Medina, 2020; ILO, 2020).

With public health conditions evolving rapidly, co-ordination among tourism officials, health officials and local authorities at domestic tourist destinations could be helpful towards developing and implementing a response to potential future outbreaks. Tourist attractions that draw dense crowds may become epicentres of infection, and containment measures must be swift. Contact tracing, including logging of visitors, will play a vital role, and safety measures such as physical distancing and masks need to be in place. Ensuring that staff in tourist attractions are not sources of COVID-19 is also necessary. Appropriate responses include strict work schedules (test-clear-work-time off) along with frequent testing. Depending on conditions, authorities in the region might be able to emulate measures taken by some European countries, including partial border reopenings, with travellers arriving from places with a low incidence of new COVID-19 cases allowed to enter in an initial phase.

\section{Uncertain tourism demand necessitates new approaches}

Even though restrictions are lifted, it is uncertain how demand for travel to ASEAN countries will be affected. Governments that have tied a return to normalcy to the availability of a vaccine may find their citizens waiting for months or even years to travel. Further, people may be less interested in traveling due to requirements such as health certificates, temperature checks or the wearing of masks on aircraft, as well as general public concern about contracting COVID-19. Given these issues, the International Air Transport Association (IATA) has urged the avoidance of quarantine measures during "re-opening" in order to stimulate tourism demand (IATA, 2020b). Potential tourists have also been affected by the economic effects of the lockdown. Income interruptions due to furloughs or job losses may reduce disposable income for some time.

\section{Countries scramble to update health policies to address the pandemic}

The COVID-19 pandemic has shown the need for countries worldwide to update their health policies. Areas of focus include the development of tracing methods, the use of education to promote better hygiene and the need for more medical personnel and healthcare facilities. International co-operation is proving crucial in the effort to develop a vaccine, and countries in Emerging Asia are assisting each other to control the spread of the virus through donations of supplies. 


\section{New contact tracing apps help monitor spread of disease}

Meticulous contact tracing using epidemiological surveys and control measures is vital for containment. In an epidemiological survey, patients' previous whereabouts are ascertained via interview and electronic means (as necessary and if available). Based on this information, people exposed to an infected person may be required to self-quarantine and monitor symptoms. In Korea, information about where an infected person has been is posted online or transmitted via SMS, allowing people to take precautionary measures. The mobile application aspect of this model has potential in most ASEAN countries, since most Southeast Asian countries have mobile penetration rates above the world average (Figure 2.10). In countries with insufficient healthcare resources, it is vital to assess how to distribute the available resources in order to promote the best possible public outcomes.

Figure 2.10. Mobile phone subscriptions per 100 population, 2018

Cellular subscriptions per 100 people

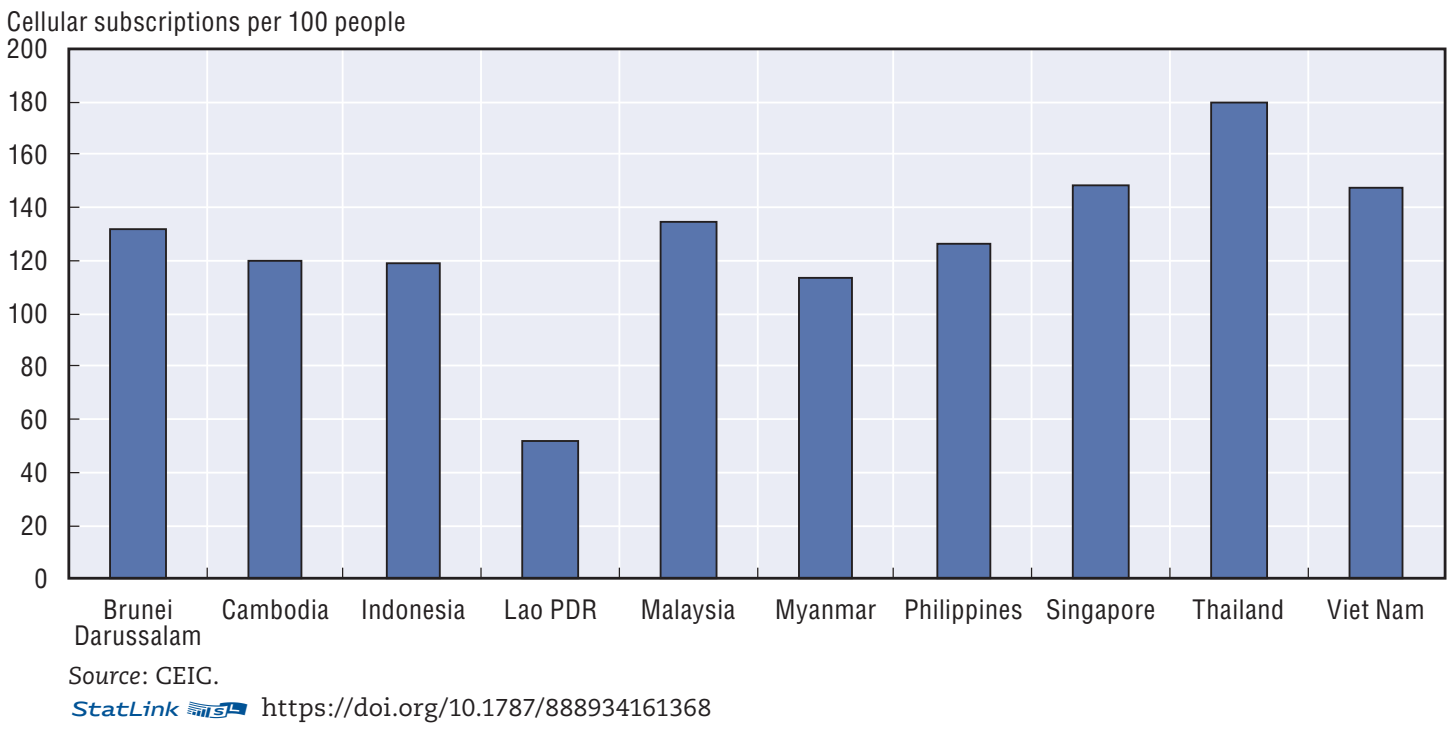

Singapore released a free application called TraceTogether for community-based contact tracing, using Bluetooth on mobile devices. Participation is voluntary, and government data show 1.1 million downloads as of 28 April. India, Indonesia and the Philippines have released similar applications. Hong Kong, China's StayHomeSafe application requires people in mandatory quarantine to wear wristbands with a $\mathrm{QR}$ code and install the app on their mobile phones. People who leave their quarantine area are subject to spot checks, arrest or prosecution. Multiple agencies within the government of Viet Nam collaborated with a state-owned enterprise to develop the NCOVI application, which allows people to report their health condition on a voluntary basis and the authorities to transmit information about the disease easily, including current statistics. The app is also used by the Ministry of Health to manage information regarding the movement of infected people or isolated cases and to detect people who may have been exposed to the virus. The Malaysian government recently launched an application similar to Viet Nam's, but it only allows for the reporting of symptoms and transmission of advice by authorities at this stage. Thailand also developed a contact-tracing application that will send data to the Department of Disease Control for analysis.

Data security is a concern for both contact tracing and general health information. Contact tracing apps rely on movement tracking, raising concerns over who has access to that information and other potential uses of it. Anonymising the data becomes difficult in 
sparsely populated areas or for people who have strict routines. Proximity-based analysis may also overestimate exposure risk. For example, standing and talking unmasked with an infected person is a greater exposure risk than simply being in a market (indoor or outdoor) at the same time as an infected person, yet contact tracing apps treat these situations identically.

\section{Populations need information on personal hygiene}

Promotion of personal hygiene is another critical aspect of controlling the spread of COVID-19. As the virus is primarily transmitted through droplets or transfer from surfaces, social distancing, handwashing and coughing etiquette help to break the chain of transmission. Social distancing may be enforced privately through voluntary co-operation or by businesses adjusting their operating procedures to prevent crowding, or via government order. Handwashing is also essential for suppressing transmission, but this remains challenging in areas where proper handwashing is not a common practice and where dwellings do not have clean running water. Providing information and education is therefore crucial, and soap or alcohol-based hand cleanser should be provided for those who do not have access. In India, the Office of the Principal Scientific Adviser to the Government (OPSA) produced a free e-book addressing some of these issues (Box 2.5).

\section{Box 2.5. India delivers advice via an e-book}

OPSA's Guidelines for Hygiene and Sanitation in Densely Populated Area, During the COVID-19 Pandemic is an e-book outlining behaviour and policy recommendations that was distributed for free. This mobile app alerts users to nearby cases of COVID-19 and helps them report symptoms. All individuals over age three in India are required to wear a mask. The app recommends wearing reusable cotton masks, and the Ministry of Health and Family Welfare provides instructions on how to make, wear and care for them.

The e-book also recommends the installation of community handwashing stations with highly chlorinated water. These stations, which can be shared by three or four households, can be constructed for approximately INR 100 (Indian rupee, USD 1.30). A foot pedal controls the flow of water, preventing recontamination of clean hands, while the chlorinated water eliminates the need for soap. The e-book also provides construction guides for more robust handwashing facilities for public toilets. It addresses sanitary toilet habits and the need to disinfect surfaces frequently, and includes instructions for homemade cleaning solutions.

\section{Emerging Asia grapples with shortages of medical equipment and staff}

Shortages of medical supplies and healthcare workers, which exist in most Emerging Asian countries, become particularly noticeable during an epidemic. The shortages include physical capital, such as medicine, equipment, care facilities and personal protective equipment (PPE) for healthcare workers and the general population, and human capital, including doctors, nurses, medical technologists and medical educators.

Since the COVID-19 pandemic began, some countries have amended or expanded their government budgets to purchase more supplies and equipment (Table 2.2). India dedicated funds to improving health infrastructure, including the development of COVID-19 testing facilities and the purchase of items such as PPE, tests, beds and ventilators. Lao PDR received outside contributions for health supplies and donations to 
help cope with COVID-19. The Philippines has enacted measures aimed at bolstering the healthcare sector, including large purchases of PPE, supplies, tests and equipment as well as financial assistance, medical coverage and insurance for patients and medical workers. The government has also suspended taxes, duties and customs fees on medical supplies and PPE, and will compensate private facilities involved in COVID-19 efforts. Viet Nam provided USD 51 million to cover healthcare expenditures from a central contingency budget maintained for unplanned spending (ADB, 2020).

Table 2.2. Examples of additional medical expenditures due to COVID-19

\begin{tabular}{|c|c|c|c|c|}
\hline \multirow[b]{2}{*}{ Country } & \multicolumn{4}{|c|}{ Purpose } \\
\hline & $\begin{array}{c}\text { Facilities, supplies and } \\
\text { testing kits }\end{array}$ & Insurance coverage & Tax exemptions & Other \\
\hline Cambodia & $\begin{array}{l}\text { Supplement healthcare } \\
\text { system }\end{array}$ & & & \\
\hline India & $\begin{array}{l}\text { Testing facilities, PPE, } \\
\text { equipment }\end{array}$ & & & \\
\hline Lao PDR & $\begin{array}{l}\text { Supplies (PPE, hand } \\
\text { sanitiser and others, } \\
\text { LAK } 24 \text { billion for rapid } \\
\text { procurement of medical } \\
\text { and protective equipment) }\end{array}$ & & & $\begin{array}{l}\text { LAK } 30 \text { billion for infection } \\
\text { prevention and control }\end{array}$ \\
\hline Philippines & $\begin{array}{l}\text { PHP } 2.9 \text { billion for } \\
\text { supplies and equipment, } \\
\text { PHP } 1.8 \text { billion for } 1 \text { billion } \\
\text { PPE sets, PHP } 53.2 \text { million } \\
\text { to the Department of } \\
\text { Science and Technology for } \\
\text { test kits }\end{array}$ & $\begin{array}{l}\text { PHP } 22 \text { billion for medical } \\
\text { coverage with death } \\
\text { benefits for COVID-19 } \\
\text { patients and associated } \\
\text { medical workers, PHP } \\
420 \text { million for general } \\
\text { COVID-19 medical coverage }\end{array}$ & $\begin{array}{l}\text { Tax, duty and expedited } \\
\text { clearance-fee exemptions } \\
\text { on healthcare equipment, } \\
\text { medical supplies and PPE, } \\
\text { and tax exemption for } \\
\text { COVID-19 donations }\end{array}$ & $\begin{array}{l}\text { PHP } 512 \text { million in } \\
\text { compensation for private } \\
\text { facilities used for COVID-19 } \\
\text { matters }\end{array}$ \\
\hline Viet Nam & $\begin{array}{l}\text { Transfer from central } \\
\text { contingency budget for } \\
\text { health spending }\end{array}$ & & $\begin{array}{l}\text { Import tax exemptions for } \\
\text { medical equipment and PPE } \\
\text { used to fight COVID-19 }\end{array}$ & \\
\hline
\end{tabular}

Source: OECD Development Centre, based on multiple sources.

Every ASEAN country has fewer hospital resources per capita than the OECD average. In some countries, people with confirmed or suspected cases of COVID-19 are transferred to designated hospitals to prevent spread of the disease within hospital environments (Brunei Darussalam, Cambodia). Makeshift hospitals may be new permanent or temporary buildings (including tents) or created from the repurposing of existing infrastructure, such as dormitories, transport stations or sports arenas. Not only do these expand hospital capacity, but the work needed to build the facilities also offers employment opportunities. Such makeshift facilities may be used for COVID-19 patients or for patients with less critical needs, allowing main hospital infrastructure to be increasingly dedicated to COVID-19 care. ASEAN countries also face shortages of medical workers, including doctors and nurses, especially those with the advanced training necessary to provide specialised care. The number of doctors and nurses per unit population is below the OECD average in each country (Figure 2.11). Physical infrastructures also matter in the fight against COVID-19. The countries with fewer beds per capita also exhibit the most elevated COVID19-related mortality rates in the Emerging Asia region (Figure 2.12). 
Figure 2.11. Doctors and nurses per 1000 population
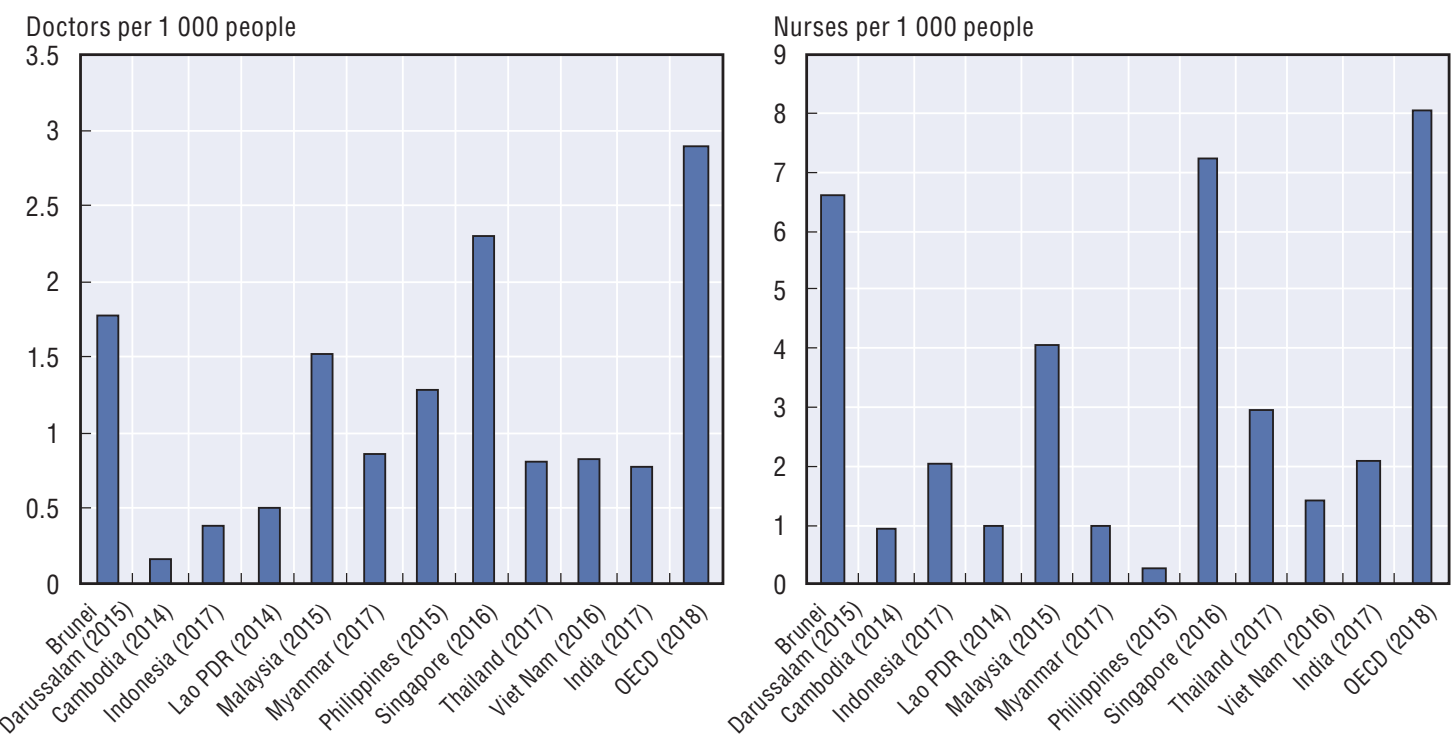

Source: World Bank Development Indicators and OECD.

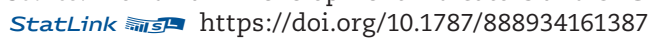

Figure 2.12. Hospital beds and COVID-19-related mortality in selected Emerging Asian economies

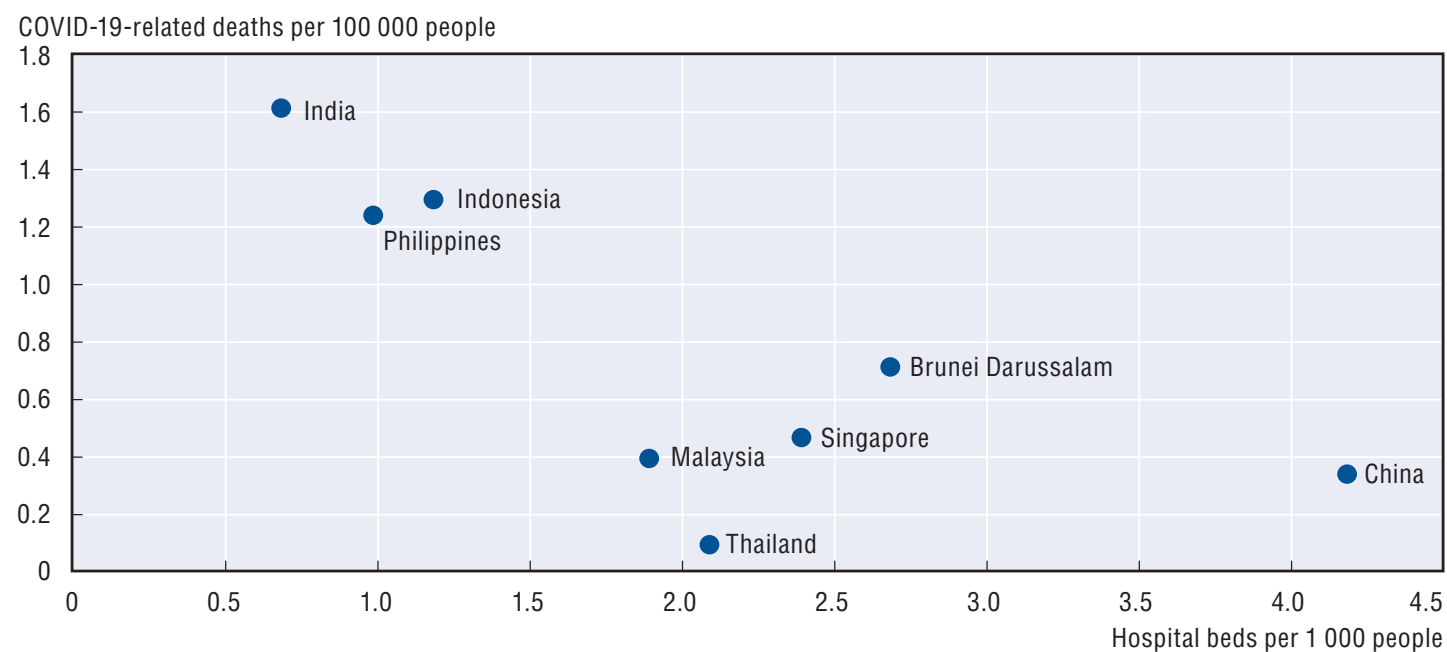

Note: Cumulative number of COVID-19-related deaths as of 10 July 2020.

Source: OECD Development Centre based on data from Johns Hopkins University and the World Bank World Development Indicators.

StatLink 部占 https://doi.org/10.1787/888934161406

ASEAN countries need to improve their medical situations. In the short term, existing resources could be mobilised. For instance, retired physicians and nurses could be recruited to ease the personnel shortage, as it was done in the United Kingdom (NHS, 2020). In the United States and Europe, medical and nursing students are altering or pausing their studies to contribute to the COVID-19 fight, allowing a temporary expansion of the medical workforce during a period where demand for medical staff is high. This is valuable during a medical emergency involving a contagious disease, as doctors and 
nurses may fall ill themselves, rendering them unable to perform their jobs. Such policies may be worth exploring for Emerging Asian countries.

Long-term efforts to improve the medical workforce should focus on education. Proper incentives are needed for students to complete the long educational process required to become a nurse or physician, particularly specialist education beyond family medicine or basic nursing. Improving the quality of education at medical schools in the region is essential, and students who train abroad must benefit from returning home. Starting and scaled wages should reflect training quality, and healthcare funds should be allocated appropriately to developing infrastructure and training staff to operate it. ASEAN countries spend far less on healthcare than the OECD average, in terms of both dollars per capita and percentage of annual GDP at purchasing-power parity, with USD 912 per capita and $4 \%$ of GDP in ASEAN, compared to USD 3857 per capita and $8.8 \%$ of GDP in the OECD in 2017 (OECD, 2020; World Bank, 2020).

\section{International co-operation takes off in search of a vaccine}

Given the highly contagious nature of COVID-19, long-term hope for controlling the virus rests in a vaccine. Along with the current global effort to create a vaccine, massproduction facilities must be prepared rapidly to ensure a smooth transition from approval to availability. Public health authorities should maintain a register of vulnerable persons so they may receive the vaccine urgently. These include front-line healthcare workers, the elderly and people with pre-existing medical conditions.

International co-operation is currently taking place in research and development of vaccines. In the United States, the National Institutes of Health (NIH) formed a consortium of public-private partnerships to conduct development and trials. This co-operative effort involves five government agencies (four in the United States including the NIH and one in Europe representing the European Union), one non-profit organisation and 16 pharmaceutical and biotechnology companies. Research is also being conducted in the United Kingdom, including at Oxford University, working with the UK National Institute for Health Research (NIHR) and the Centre for Epidemic Preparedness Innovations (CEPI). The European Union announced in March that EUR 47.5 million had been set aside for this work (Table 2.3).

Table 2.3. COVID-19 research contributions and phases, by selected countries and organisations

\begin{tabular}{l|l}
\hline \multicolumn{1}{c|}{ Country/Organisation } & \multicolumn{1}{c}{ Contribution and phase of research/trials } \\
\hline Canada & CAD 40 million to CEPI \\
CEPI & $\begin{array}{l}\text { AstraZeneca (USD } 383 \text { million); Clover Biopharmaceuticals Australia (USD 3.5 million); } \\
\text { Institut Pasteur, Themis, University of Pittsburgh (USD 4.9 million); Novavax (Phase I/II } \\
\text { trials, USD } 388 \text { million); Stevanato Group (vaccine vials); University of Hong Kong; University } \\
\text { of Oxford; University of Queensland }\end{array}$ \\
$\begin{array}{ll}\text { China } \\
\text { European Investment Bank }\end{array}$ & $\begin{array}{l}\text { Sinopharm (SOE) } \\
\text { BioNTech } \\
\text { European Union }\end{array}$ \\
$\begin{array}{l}\text { Leading "Access to COVID-19 Tools (ACT) Accelerator" programme, Canada CAD 120 million } \\
\text { (ACT Accelerator), Luxembourg EUR 800 000 (COVID-19 Therapeutics Accelerator), Serbia } \\
\text { EUR 100 000 (CEPI) }\end{array}$ \\
$\begin{array}{l}\text { India } \\
\text { Institut Pasteur }\end{array}$ \\
$\begin{array}{l}\text { Bharat Biotech and Zydus Cadila (Phase I/II trials) } \\
\text { National Institute of Hygiene and Epidemiology of Vietnam and Institut Pasteur du Laos } \\
\text { studying origin and transmission, to detect previously unnoticed infections. Institut Pasteur } \\
\text { of Cambodia assessing viral transmission risk in Mekong Region wet markets. }\end{array}$ \\
$\begin{array}{l}\text { Indonesia } \\
\text { Eijkman Institute for Molecular Biology }\end{array}$ \\
\hline
\end{tabular}


Table 2.3. COVID-19 research contributions and phases, by selected countries and organisations (cont.)

\begin{tabular}{l|l}
\hline \multicolumn{1}{c|}{ Country/Organisation } & \multicolumn{1}{c}{ Contribution and phase of research/trials } \\
\hline Luxembourg & COVID-19 Therapeurics Accelerator \\
Malaysia & Malaysia and Turkey will collaborate in vaccine research \\
Norway & NOK 36 million to CEPI \\
Philippines & Reward for vaccine discovery \\
Singapore & BioNTech \\
Thailand & National Vaccine Institute (primate trials successful, plan to start human trials in Oct/Nov) \\
United States & Multiple vaccine candidates in Phase I or II trials, through PPP arrangements \\
United Kingdom & GBP 2.2 million to a vaccine research team, and GBP 0.4 million to a team researching \\
& vaccine production scaling, both at Oxford University and collaborating with NIHR. Phase III \\
& trials for vaccine in progress \\
\hline
\end{tabular}

Source: OECD Development Centre's compilation based on various government and organisation websites.

As part of global co-operation on COVID-19, the United Nations and other international agencies have called for urgent financial support to purchase and distribute supplies and equipment. The creation of a Global Humanitarian Response fund worth more than USD 2 billion was requested in March, and in April the World Health Organization (WHO) indicated that about one quarter of that amount (USD 550 million) had been raised. The UN Central Emergency Response Fund also released USD 95 million. In response to COVID-19, ASEAN nations have both received and provided assistance (Box 2.6).

\section{Box 2.6. International pandemic support for and from ASEAN countries}

As part of international co-operation on the pandemic, the United States has provided approximately USD 18.3 million in assistance to ASEAN member states for the construction and operation of laboratories, risk communication, infection prevention and control (including contact tracing), training of staff and in-kind donations of PPE and respirators. The United States has also provided human capital assistance through training or on-site expertise for a number of ASEAN member states and for ASEAN as a whole. France and ASEAN are co-operating through the French development agency's COVID-19 Health in Common Project, which provided EUR 2 million to laboratories in Cambodia, Lao PDR, Myanmar, the Philippines and Viet Nam for the purchase of diagnostic tests, PPE and other medical and laboratory equipment. ASEAN and Australia arranged to strengthen co-operation after a virtual meeting on 26 June, while Canada donated medical masks worth CAD 4 million (Canadian dollars) to the ASEAN Secretariat and select member states (ASEAN, 2020a; ASEAN, 2020b).

Co-operation among ASEAN member states and expanded groupings (ASEAN Plus Three and ASEAN Plus Six) has been a defining feature of the region's response to COVID-19. China donated masks and other medical supplies to almost all ASEAN countries. Singapore has been a critical supplier, sending test kits, PCR machines, ventilators and PPE to Brunei Darussalam, Indonesia, Malaysia, Myanmar, the Philippines and Viet Nam. As certain ASEAN countries succeed in containing COVID-19, they can assist countries that are still struggling. Viet Nam, which as of 2 July had recorded very few COVID-19 cases and not a single death, authorised the production of ventilators to be transferred to the Russian Federation and Ukraine, two countries that are still in the thick of the COVID-19 struggle. Viet Nam has also sent supplies, mainly masks, to countries in ASEAN Plus Three and Europe as well as to the United States and Cuba.

Source: Compilation based on press releases, news articles and CSIS (2020b), https://www.csis.org/ programs/southeast-asia-program/southeast-asia-covid-19-tracker-0\#international (as of 6 July). 


\section{Emerging Asia strengthens collaboration to fight the pandemic}

Emerging Asian countries quickly recognised the need to strengthen collaboration and co-operation to combat the pandemic. Since the first COVID-19 cases were reported in January, ASEAN leaders and their counterparts in China, Japan and Korea have stepped up efforts to provide a collective response. By late March the virus had reached all ASEAN countries (Table 2.4).

Table 2.4. First confirmed cases in ASEAN countries

\begin{tabular}{cc}
\hline Country & First case confirmed \\
\hline Thailand & 13 January 2020 \\
\hline Viet Nam & 23 January 2020 \\
\hline Singapore & 23 January 2020 \\
\hline Malaysia & 25 January 2020 \\
\hline Cambodia & 27 January 2020 \\
Philippines & 30 January 2020 \\
Indonesia & 2 March 2020 \\
Brunei Darussalam & 10 March 2020 \\
Myanmar & 23 March 2020 \\
Lao PDR & 24 March 2020 \\
\hline
\end{tabular}

Source: ASEAN Secretariat (2020c).

Region-wide initiatives are being implemented to support national measures, in particular in the framework of ASEAN and ASEAN Plus Three (Table 2.5). The initiatives, particularly those related to the health sector, involve facilitating and maximising the use of existing forms of co-operation and mechanisms (Box 2.7).

Table 2.5. Examples of region-wide pandemic initiatives in ASEAN and ASEAN Plus Three

\begin{tabular}{|c|c|}
\hline Initiative & Programmes \\
\hline $\begin{array}{l}\text { Establish an ASEAN COVID-19 Response } \\
\text { Fund }\end{array}$ & $\begin{array}{l}\text { Supporting the provision of medical supplies and equipment and preventive efforts in all } \\
\text { member states }\end{array}$ \\
\hline Strengthen co-operation in public health & $\begin{array}{l}\text { Exchanges of information and sharing of experience and best practices in research and } \\
\text { development of vaccines and anti-viral medicines, in clinical treatment and in enhancing } \\
\text { the capacity of public health systems and response to pandemics }\end{array}$ \\
\hline $\begin{array}{l}\text { Run an information platform among ASEAN } \\
\text { Member State officials working at crisis } \\
\text { centres and/or disease prevention and } \\
\text { control }\end{array}$ & $\begin{array}{l}\text { The ASEAN Emergency Operations Centre Network for public health emergencies runs } \\
\text { a platform to share timely information, including on new confirmed cases and national } \\
\text { measures, through channels including social media platforms, WhatsApp, websites, etc. }\end{array}$ \\
\hline $\begin{array}{l}\text { Assess risks through the ASEAN } \\
\text { BioDiaspora programme }\end{array}$ & $\begin{array}{l}\text { Real-time web-based risk assessment tools linking multiple datasets, including air travel } \\
\text { data, demography data, human population density, animal populations, industrialisation } \\
\text { and utility distribution, vector locations and other relevant information }\end{array}$ \\
\hline $\begin{array}{l}\text { Strengthen scientific co-operation in } \\
\text { epidemiological research }\end{array}$ & $\begin{array}{l}\text { Strengthening scientific co-operation in epidemiological research including through } \\
\text { the ASEAN+3 Field Epidemiology Training Network, co-ordination on rapid research, } \\
\text { development, manufacturing and distribution of diagnostics, anti-viral medicines and } \\
\text { vaccines, adhering to the objectives of efficiency, safety, equity, accessibility and } \\
\text { affordability and actively sharing and leveraging digital technologies and innovation to } \\
\text { promote a science-based response to combat COVID-19 }\end{array}$ \\
\hline $\begin{array}{l}\text { Enhance co-operation in trade and } \\
\text { investment }\end{array}$ & $\begin{array}{l}\text { Reaffirming commitments to keep markets open for trade and investment, enhancing } \\
\text { co-operation on food security among ASEAN+3 countries, such as the utilisation of } \\
\text { the ASEAN Plus Three Emergency Rice Reserve, and strengthening the resilience and } \\
\text { sustainability of regional supply chains, especially for essential goods such as food, } \\
\text { commodities, medicine and medical supplies }\end{array}$ \\
\hline
\end{tabular}

Source: OECD Development Centre's compilation based on various official statements and press releases. 


\section{Box 2.7. Health co-operation mechanisms in the framework of ASEAN and ASEAN Plus Three}

1. ASEAN Emergency Operations Centre Network for public health emergencies

2. ASEAN BioDiaspora Virtual Centre for big data analytics and visualisation

3. Regional Public Health Laboratories Network through the Global Health Security Agenda platform

4. ASEAN Risk Assessment and Risk Communication Centre

5. ASEAN Plus Three Field Epidemiology Training Network

6. ASEAN Coordinating Council Working Group on public health

7. ASEAN and ASEAN Plus Three Senior Officials Meeting for Health Development

8. ASEAN and ASEAN Plus Three Health Ministers platforms

9. Public health laboratories network under the ASEAN Health Cluster 2 on Responding to All Hazards and Emerging Threats

Source: ASEAN (2020c); Djalante, R. et al. (2020), The ASEAN's Responses to COVID-19: A Policy Sciences Analysis, https://papers.ssrn.com/sol3/papers.cfm?abstract id=3595012.

ASEAN has also organised ministerial meetings in response to the pandemic. On 19 February, ASEAN defence ministers met in Viet Nam and issued a joint statement on co-operation against COVID-19. The ministers reaffirmed their commitment to promoting defence collaboration, including: enhancing co-operation among ASEAN defence establishments to organise activities to share information and best practices; leveraging the Network of ASEAN Chemical, Biological and Radiological Defence Experts to enhance professional linkages and promote scientific co-operation to manage infectious disease outbreaks; encouraging new initiatives and ways of co-operating; and contributing to ASEAN's efforts to counter fake news regarding the COVID-19 outbreak.

\section{ASEAN countries step up co-operation on economic resilience and public health}

The ASEAN economic ministers also held a retreat in Viet Nam, on 10 March, and issued a joint statement on strengthening economic resilience in the region in response to the COVID-19 outbreak (ASEAN, 2020d). The ministers agreed to take collective action to mitigate the economic impact of the pandemic, such as: keeping ASEAN markets open for trade and investment; strengthening regional information sharing and collaboration in responding to economic challenges; working closely with industries to encourage confidence in Southeast Asia as a trade and investment hub and tourism destination; leveraging technologies and digital trade to allow businesses, especially MSMEs, to stay afloat amid the outbreak; strengthening long-term supply-chain resilience and sustainability, in particular by implementing the Master Plan on ASEAN Connectivity 2025; enhancing economic co-operation with external and development partners to include initiatives aimed at strengthening regional supply chains; building on existing trade facilitating platforms, such as the ASEAN Single Window, to promote and support supplychain connectivity; refraining from actions that could create unnecessary inflationary pressures or adversely impact food security; ensuring the availability of basic goods and commodities; and continuing to address non-tariff barriers, particularly those that impede the smooth flow of goods and services in supply chains. 
In the health sphere, the ASEAN Coordinating Council Working Group on Public Health Emergencies held its first meeting at the end of March, sharing updates on the situation and measures taken in each country. The panel committed to co-operate and provide a collective response to COVID-19. ASEAN and ASEAN Plus Three health ministers also held video conferences on 7 April and adopted joint statements to enhance co-operation in response to the pandemic (ASEAN, 2020e). The ministers agreed to enhance the timely exchange and sharing of data and information on COVID-19, including prevention, detection, control and response measures, epidemiologic surveillance updates, risk assessment results, epidemiological and clinical studies on the virus and the disease, and technical guidelines, through existing ASEAN health sector co-operation mechanisms. They also agreed to strengthen co-operation in risk communication, to work together to prevent misinformation and fake news, and to maximise the use of digital technology for efficient exchange of information. Other areas of agreement included: co-ordination of public health responses such as contact tracing; enhancing co-operation in capacitybuilding on public health emergency preparedness and response; and continued collaboration in learning from regional and national experiences. The ministers agreed: to ensure that all infected persons can access healthcare services, including migrants and vulnerable groups; to collaborate with regional and global partners such as the WHO, academia and the private sector to promote research and development on the disease; and to provide timely assistance to affected national health systems in the region and revitalise health systems in their transition to recovery.

On 14 April, ASEAN and ASEAN Plus Three member countries deepened their co-operation through a special summit via video conference on collective responses to COVID-19. In addition to the subjects discussed at the previous meeting, the leaders agreed to reallocate existing ASEAN Plus One and ASEAN Plus Three funds and establish a COVID-19 ASEAN Response Fund to fight the pandemic. The fund aims to support provision of medical supplies and equipment and preventive efforts in all member states.

More recently, the 36th Annual ASEAN Summit was held virtually on 26 June, presenting an opportunity for leaders of ASEAN Member States to reaffirm and flesh out their commitments to regional co-operation, especially in the context of COVID-19. Strengthening ASEAN health security was noted as a top priority and it was acknowledged that public health emergency responses must be collective and collaborative efforts, co-ordinated not only within ASEAN, but also between ASEAN and its partners. Such efforts could take the form of collaborative scientific research, assistance in the development and procurement of vaccines and medicines, strengthening of medical and non-medical supply chains, as well as navigating a safe and robust economic recovery. The Summit announced the establishment of the COVID-19 Response Fund. The establishment of the ASEAN Regional Reserve of Medical Supplies and Standard Operating Procedures for future public health emergencies was encouraged. The importance of improving synergy among regional frameworks, such as ASEAN Plus One, ASEAN Plus Three, East Asia Summit, ASEAN Regional Forum and ASEAN Defence Ministers' Meeting Plus, was also stressed. In addition to the Summit, a series of video conferences are also being conducted with various countries and dialogue partners to exchange information, and share expertise, lessons learned and best practices, as well as updates on COVID-19.

\section{Region-wide initiatives tackle risk assessment and information sharing}

Collective initiatives are also implemented in the area of risk assessment, readiness and response planning through the ASEAN BioDiaspora programme. A real-time, web-based risk assessment tool, it links multiple datasets including air travel data, the demography data of ASEAN Member States, human population density, animal populations, industrialisation and utility distribution, vector locations and other relevant 
datasets. It consists of two different tools. The "explorer tool" provides big data and advanced analytics to track and assess infectious disease threats in any place in the world. It shows where the disease occurs, the factors driving the spread of disease, how connected the outbreak locations are with the rest of the world and what could happen if a case is imported into a given country. The "insights tool" provides information about global infectious disease threats. It demonstrates which disease events are relevant to national and regional locations, the risk of disease exportation or importation and possible spread to a specific location. The ASEAN BioDiaspora Regional Virtual Centre produces risk assessment reports pertaining to COVID-19, with highlights and a situational overview of the virus, a timeline of international dissemination, a public health outlook and the risk of importation through air travel. It also provides information on cases and fatalities related to COVID-19 and travel advisories among ASEAN Member States in response to the virus.

ASEAN member states also exchange information on laboratory readiness, technical and material support, and laboratory surveillance through the Regional Public Health Laboratories Network. Another body, the ASEAN Risk Assessment and Risk Communication Centre, disseminates preventive and control measures, including those that address false news, hoaxes and misinformation on social media related to COVID-19. The countries are also strengthening scientific co-operation in epidemiological research, including through the ASEAN+3 Field Epidemiology Training Network, and co-ordination towards rapid research, development, manufacturing and distribution of diagnostics, anti-viral medicines and vaccines, and are actively sharing and leveraging digital technologies and innovation.

\section{Regional leaders agree to bolster trade, investment and the labour market}

The region's leaders also reaffirmed commitments to enhance co-operation in trade and investment, in particular by keeping markets open. This initiative also focuses on ensuring food security, for example by utilising the ASEAN Plus Three Emergency Rice Reserve, and on strengthening regional supply chains, especially for essential goods such as food, commodities, medicines and medical supplies.

Labour and employment were in the spotlight on 14 May when ASEAN labour ministers held a virtual meeting to discuss responses to the impact of COVID-19. They agreed: to facilitate access of infected workers to healthcare services; to strengthen the effectiveness of labour-market policies at national and regional levels and of occupational safety and health standards and social protection systems; and to provide assistance to ASEAN migrant workers affected by the pandemic in each other's countries. The ministers agreed to share best practices on measures to help workers and employers during the outbreak and to enhance public communications for timely updates on labour and employment policies and to counter misinformation.

\section{APEC shares in collective response to COVID-19}

The Asia-Pacific Economic Co-operation (APEC) forum is also being used for collective initiatives on the pandemic. On 5 May, the ministers responsible for trade in APEC economies issued a statement pledging to work together towards mitigating the health and economic impact of COVID-19. They committed to facilitate the flow of goods and services across borders, including medicines, medical supplies and equipment, agricultural and food products, and other supplies; to minimise disruptions to global supply chains; and to work closely in identifying and resolving any unnecessary barriers to trade. The ministers aim to ensure that trading links stay open and will explore ways to facilitate necessary movement of people across borders without undermining efforts 
to avoid the spread of the virus. In response to the economic challenges brought on by the pandemic, the countries are also developing a co-ordinated approach to collecting and sharing information on policies and measures, including short- and long-term economic stimulus packages. This endeavour strives to ensure that the experience of one economy can translate into best practices for the region as a whole. Considering the importance of the digital economy amid the pandemic, the countries also stated their commitment to strengthen APEC's digital agenda, including e-commerce and related services.

\section{Broader collaboration is needed to counter the pandemic's socio-economic impact}

Regional responses as the pandemic began in January and February 2020 were considered to be relatively slow and to lack unity (Djalante et al., 2020). Since then, ASEAN has intensified its efforts to forge a coherent response to COVID-19, as described above. Nevertheless, many of the initiatives focus on exchanging information and sharing experiences and best practices among member countries. While this is crucial, other initiatives, such as financial co-operation, need to be strengthened.

As for ASEAN collective responses focused on the health sector, they are unquestionably necessary. Yet the pandemic is having a socio-economic impact on other sectors, including tourism, hospitality, financial markets, the banking sector, manufacturing, etc. There is thus a need to broaden the coverage of region-wide initiatives. Going forward, countries will need to ensure that responses not only to the current emergency, but also to future outbreaks, are timely and effectively co-ordinated. These responses should be longer-term and forward looking to increase the region's resilience and better prepare for potential future pandemics.

\section{Conclusion}

The COVID-19 pandemic has affected Emerging Asian countries in many ways beyond the immediate health crisis. Negative impacts and pressures on firms, the labour market and households are already apparent, although they vary by sector. In addition to policies to prevent the spread of the virus, such as border closures, lockdowns and restrictions on social interaction, all countries in the region have taken measures to ease the economic shock, including stimulus packages, but further efforts are needed. Continuous policy support is necessary to overcome the issues confronting the sectors most affected by the pandemic.

- The role of digitalisation and the opportunities it brings have become more obvious during the pandemic. Digital tools proved essential during lockdowns to ensure the continuity of essential services. However, efforts to mobilise digital innovations remain limited in some emerging economies. While most countries in Emerging Asia have succeeded in leveraging the opportunities created by digitalisation, a few are less well equipped than their regional peers. It is thus important to facilitate innovation and the use of digital tools. Countries with limited ICT infrastructure and Internet availability should step up efforts to close this gap and make the benefits of digitalisation available to a broader range of stakeholders. Ensuring cyber resilience is also of the utmost importance given the increased reliance on digital tools.

- Various emergency measures have been implemented by governments in the region to prop up the tourism sector, which has been particularly devastated by the pandemic. A strategy for the short to medium term could include direct support to the most affected agents, combined with enhanced safety measures and protocols to revive domestic tourism and envisage the return of international travellers. Co-ordination among tourism officials, health officials and local authorities at tourist destinations is essential for developing and implementing a plan to respond 
to cases of COVID-19. A more holistic approach involving upskilling or job training for affected workers will be needed in the medium and longer term.

- In addition to immediate healthcare responses to curtail the spread of the virus, including containment measures and information sharing, efforts to cope with the long-term challenges of the pandemic are needed. Key elements of these efforts are international co-operation for research and development, and strengthening healthcare systems to prepare for future outbreaks.

- It is crucial to strengthen the region-wide initiatives taken within various frameworks as part of immediate responses to the pandemic. Broadening the coverage of these efforts and ensuring longer-term measures for better preparedness will be particularly important.

Overall, although various measures are in place to cope with the pandemic, their impact is yet to be seen. In view of the rapid evolution of the pandemic and its impacts, continuous monitoring will be needed to provide more targeted and effective support measures. 


\section{References}

ADB (2020), ADB COVID-19 Policy Database (database), https://covid19policy.adb.org/.

App Annie (2020) "Game downloads surge as consumers at home look to stay entertained", App Annie Market Data, https://www.appannie.com/en/insights/market-data/game-downloadssurge-as-consumers-at-home-look-to-stay-entertained/ (accessed on 21 May 2020).

Apptopia, Performance Data on 7+ Million Apps (database), https://apptopia.com/performance-data (accessed on 4 June 2020).

ASEAN (2015), ASEAN Services Integration Report: A Joint Report by the ASEAN Secretariat and the World Bank, ASEAN Secretariat, Jakarta, and World Bank, Washington, DC, http://documents1. worldbank.org/curated/en/759841468178459585/pdf/100637-Revised-WP-PUBLIC-Box393257BASEAN-Report-web.pdf.

ASEAN (2020a), "ASEAN, Australia to strengthen co-operation amid COVID-19 pandemic", Association of Southeast Asian Nations, https://asean.org/asean-australia-strengthenco-operation-amid-covid-19-pandemic/.

ASEAN (2020b), "Canada donates personal protective equipment to ASEAN for COVID-19 prevention", Association of Southeast Asian Nations, https://asean.org/canada-donatespersonal-protective-equipment-asean-covid-19-prevention/.

ASEAN (2020c), "Covid-19: A collective response in ASEAN", The ASEAN Magazine, Issue 1/May 2020, Association of Southeast Asian Nations.

ASEAN (2020d), "ASEAN Health Ministers enhance co-operation in fighting COVID-19 pandemic", Association of Southeast Asian Nations, https://asean.org/asean-health-ministers-enhanceco-operation-fighting-covid-19-pandemicl.

ASEAN (2020e), "ASEAN health sector efforts in the prevention, detection and response to coronavirus disease 2019 (COVID-19)", Association of Southeast Asian Nations, https://asean. org/?static_post=updates-asean-health-sector-efforts-combat-novel-coronavirus-covid-19.

Autoriti Monetari Brunei Darussalam (2018), “Digital payment roadmap for Brunei Darussalam 2019-2025", https://www.ambd.gov.bn/SiteAssets/Lists/News/News/AMBD\%20Press\%20Release\%20 \%20Digital\%20Payment\%20Roadmap nra.pdf.

Bloomberg (2020a), "How Alibaba's Lazada turned produce dumped in virus crisis into a business", 13 May 2020, https://www.bloomberg.com/news/articles/2020-05-13/how-alibaba-s-lazadaturned-discarded-vegetables-into-a-business.

Bloomberg (2020b), “Ride-hailing giant Gojek raises \$1.2 billion for clash with Grab”, 17 March 2020, https://www.bloomberg.com/news/articles/2020-03-17/ride-hailing-giant-gojek-raises-1-2billion-for-clash-with-grab.

Booth, A., N. Mohr and P. Peters (2016), "The digital utility: New opportunities and challenges", McKinsey \& Company, 12 May 2016, https://www.mckinsey.com/industries/electric-powerand-natural-gas/our-insights/the-digital-utility-new-opportunities-and-challenges.

Business of Apps (2020), "Zoom revenue and usage statistics 2020", https://www.businessofapps. com/data/zoom-statistics/ (accessed on 4 June 2020).

CAAT (2020), "Notification on Conditions for Aircraft Permission to Enter Thailand (No. 2)", Civil Aviation Authority of Thailand, https://www.caat.or.th/en/archives/51895.

Cipla (2020), "Cipla stands strong with India in the battle against COVID-19", Cipla Limited, https://www.cipla.com/sites/default/files/Press\%20Release Cipla\%20stands\%20strong\%20 with\%20India\%20in\%20the\%20battle\%20against\%20COVID_0.pdf.

CNA (2020), "COVID-19: MICE sector and spas to resume operations from Jul 1, says Malaysia senior minister", Channel News Asia, https://www.channelnewsasia.com/news/asia/malaysia-covid19-mice-spas-wellness-centres-sops-ismail-sabri-12873510 (accessed on 3 July 2020).

CSIS (2020a), Significant Cyber Incidents (timeline), Centre for Strategic and International Studies, https://www.csis.org/programs/technology-policy-program/significant-cyber-incidents.

CSIS (2020b), Southeast Asia COVID-19 Tracker, Centre for Strategic and International Studies, https://www.csis.org/programs/southeast-asia-program/southeast-asia-covid-19-tracker0\#international (accessed on 6 July 2020).

de Souza, R. et al. (2019), Logistics Barriers in ASEAN, The Logistics Institute Asia Pacific White Papers Series, Vol. 8/June, https://www.tliap.nus.edu.sg/wp-content/uploads/2019/04/08-JunSCT03 Logistics-Barriers-in-ASEAN.pdf.

Djalante, R. et al. (2020), The ASEAN's Responses to COVID-19: A Policy Sciences Analysis, Elsevier, https://papers.ssrn.com/sol3/papers.cfm?abstract id=3595012.

Enterprise Singapore (2020), "E-Commerce booster package", https://www.enterprisesg.gov.sg/ industries/type/retail/e-commerce-booster-package.

Financial Times (2020), "Asia-Pacific makes a tentative return to international travel”, https://www. ft.com/content/72bdabea-0ebd-4051-961a-ad18e30bf9e9.

Gig.U (2014), From Gigabit Testbeds to the "Game of Gigs", Third Annual Report of Gig.U, http://www.gig-u.org/cms/assets/uploads/2012/12/81714-Gig.U-Final-Report-Draft-1.pdf. 
Grier, R. (2020), "Post COVID-19 lockdown MICE business strategies", 4Hoteliers, https://www.4hoteliers. com/features/article/13576.

Hale, T., S. Webster, A. Petherick, T. Phillips and B. Kira (2020), "Oxford COVID-19 Government Response Tracker", Blavatnik School of Government, available at: https://www.bsg.ox.ac.uk/ research/research-projects/coronavirus-government-response-tracker (accessed on 10 July 2020).

IATA (2020a), "COVID-19 Impact on Asia-Pacific aviation worsens", International Air Transport Association, 24 April 2020, https://www.iata.org/en/pressroom/pr/2020-04-24-01/.

IATA (2020b), "IATA proposes alternatives to quarantine", International Air Transport Association, 24 June 2020, https://www.iata.org/en/pressroom/pr/2020-06-24-02/.

ICCA (2020), "Good practice guidance: Addressing COVID-19 requirements for re-opening business events", International Congress and Convention Association, https://www.iccaworld.org/ covid-19/.

ILO (2020a), "ILO Monitor: COVID-19 and the world of work. Second edition", 7 April 2020, https:// www.ilo.org/wcmsp5/groups/public/---dgreports/---dcomm/documents/briefingnote/ wcms 740877.pdf. See also: ILO (2020), ILO Policy Brief on COVID-19, International Labour Organization, https://www.ilo.org/global/topics/coronavirus/impacts-and-responses/ WCMS 739049/lang--en/index.htm.

ILO (2020b), "Thematic Brief: COVID-19 and employment in the tourism sector: Impact and response in Asia and the Pacific", 24 April 2020, https:/www.ilo.org/wcmsp5/groups/public/--asia/---ro-bangkok/documents/briefingnote/wcms 742664.pdf.

IMF (2020), "Policy Responses to COVID-19", https://www.imf.org/en/Topics/imf-and-covid19/ Policy-Responses-to-COVID-19.

India Today (2020), "Zoom India chief says consumers love it, not worried about competitors", https://www.indiatoday.in/technology/features/story/zoom-india-chief-says-consumers-loveit-not-worried-about-competitors-1680083-2020-05-20.

Jakarta Post (2020), "Jakartans called to work from home during the outbreak. Not everyone has the option.", 23 March 2020, https://www.thejakartapost.com/news/2020/03/23/jakartanscalled-to-work-from-home-during-outbreak-not-everyone-has-the-option.html.

Jefriando, M. and G. Suroyo (2020), "Indonesia announces nearly $\$ 750 \mathrm{mln}$ stimulus in response to coronavirus", 25 February 2020, https://www.nasdaq.com/articles/indonesia-announcesnearly-\%24750-mln-stimulus-in-response-to-coronavirus-2020-02-25.

Kit, T. (2020), "S\$4 billion support package for workers, firms amid COVID-19 outbreak", 21 February 2020, https://www.channelnewsasia.com/news/singapore/budget-2020-s-4-billionsupport-package-for-workers-firms-amid-12446082.

Medina, A. (2020), "Malaysia Issues Stimulus Package to Combat COVID-19 Impact", 19 March 2020, https://www.aseanbriefing.com/news/malaysia-issues-stimulus-package-combat-covid-19impact/.

NHS (2020), "Thousands of former NHS staff are back on the front line in the NHS fight against coronavirus", 12 April 2020, https://www.england.nhs.uk/2020/04/thousands-of-former-nhsstaff-are-back-on-the-front-line-in-the-nhs-fight-against-coronavirus/.

OECD (2020), "Health spending" (indicator), https://doi.org/10.1787/8643de7e-en, (accessed on 22 July 2020).

Omdia (2020), Application Market Forecast Tool: Quarterly Detail, Omdia Technology, https://technology. informa.com/621994/application-market-forecast-tool-amft-quarterly-detail-update-q1-2020.

Quest Mobile (2020), Quest Mobile TRUTH Database, https://www.questmobile.com.cn/en (accessed on 18 February 2020).

Speedtest (2020), Speedtex Global Index (database), https://www.speedtest.net/global-index (accessed on 30 June 2020).

Tech in Asia (2020), "Philippine cloud kitchen start-up CloudEats nets $\$ 1.4 \mathrm{~m}$ in seed round", available at: https://www.techinasia.com/cloudeats-nets-1m-seed (accessed on 11 May 2020).

World Bank (2020), World Development Indicators (database), World Bank Group, Washington, DC, https://databank.worldbank.org/source/world-development-indicators (accessed on 29 June 2020).

World Bank (2019a), Myanmar Economic Monitor: Building Reform Momentum, World Bank Group, Washington, DC, http://documents.worldbank.org/curated/en/326771560523871008/pdf/ Building-Reform-Momentum.pdf.

World Bank (2019b), The Digital Economy in Southeast Asia: Strengthening the Foundations for Future Growth, Digital Development Partnership, World Bank Group, Washington, DC, http:// documents1.worldbank.org/curated/en/328941558708267736/pdf/The-Digital-Economy-inSoutheast-Asia-Strengthening-the-Foundations-for-Future-Growth.pdf.

World Economic Forum (2017), Digital Transformation Initiative: Mining and Metals Industry (white paper), World Economic Forum, Geneva, http://reports.weforum.org/digital-transformation/ wp-content/blogs.dir/94/mp/files/pages/files/wef-dti-mining-and-metals-white-paper.pdf. 



\section{Chapter 3}

\section{Boosting education quality in Emerging Asia: Recommendations from PISA 2018}

The COVID-19 pandemic has left a majority of students worldwide out of school, even if temporarily. While ensuring continuity of education and learning, countries in the region need to address various challenges to improve the quality of education. Access to education will need to be further improved, while at the same time paying more attention to its quality. Properly trained teachers as well as appropriate teaching strategies and a positive environment are crucial to ensure productive learning. Addressing socio-economic divides in various aspects, including digital infrastructure, as well as gender gaps in students' participation and performance is necessary. 


\section{Introduction}

The spread of COVID-19 has left a majority of learners across the globe out of school, even if temporarily. While learning has continued in some way or another, the consequences of the school closures have been particularly damaging for vulnerable students. Unfortunately, the type of resources that learning at home requires, such as access to digital resources and a quiet place to study, motivated, supportive and highly skilled parents and teachers, and the ability to learn autonomously, are far from universal. Vulnerable students tend to have fewer of these resources. While the full consequences of the school closures cannot be evaluated without hindsight, the Programme for International Student Assessment (PISA) 2018 results can provide a valuable reference point for education systems.

PISA is a triennial survey of 15 -year-old students around the world that assesses the extent to which they have acquired key knowledge and skills essential for full participation in social and economic life. PISA assessments in reading, mathematics, science and innovative domains do not just ascertain whether students near the end of their compulsory education can reproduce what they have learned, they also examine how well students can extrapolate from what they have learned and apply their knowledge in unfamiliar settings, both in and outside of school. In its last cycle, about 600000 students sat the assessment, representing about 32 million 15-year-olds in the schools of 37 OECD countries and 42 partner countries and economies.

PISA asks students, principals, teachers and parents, questions about students' background and attitudes towards learning, and about key factors that shape their learning in and outside of school; by doing so, PISA can identify the characteristics of students, schools and education systems that perform well.

PISA 2018 assessed the cumulative outcomes of education and learning of children between the ages of 15 years and 3 months and 16 years and 2 months who have been enrolled in an educational institution at grade 7 or above. All such students were eligible to sit the PISA assessment regardless of the type of educational establishment in which they were enrolled or whether they were enrolled in full-time or part-time education. Not all of the students who were eligible to sit the PISA assessment were actually assessed. A twostage sampling procedure first selected a representative sample of at least 150 schools and, in the second stage, roughly 42 students were selected within those schools. In PISA 2018, a majority of countries and economies assessed between 5000 and 7500 students, but in Southeast Asia, Indonesia and Thailand assessed a larger number of students.

\section{The participation of Southeast Asian countries in PISA}

Some education systems in Southeast Asia have a long tradition of participation in the PISA assessments, whereas others only started participating in 2018. Indonesia and Thailand have participated in all cycles since PISA first assessed student learning outcomes in 2000; Malaysia and Singapore joined PISA in 2009; Viet Nam took part for the first time in PISA 2012; and Brunei Darussalam and the Philippines did so in PISA 2018 (Table 3.1). Cambodia, for its part, participated in PISA for Development (PISA-D), a project whose goal was to encourage and facilitate PISA participation by interested and motivated low-and middle-income countries (see Box 3.1).

Students in all countries in the region, except in Viet Nam, took the computer-based assessment, which allows education systems to take full advantage of the assessment (Table 3.2).

All countries and economies in PISA participate in the reading, mathematics, and science assessments. In addition, PISA offers the possibility of assessing financial literacy and each cycle explores a new "innovative domain", such as problem solving (PISA 2012), 
collaborative problem Solving (PISA 2015) and global competence (PISA 2018). In PISA 2018, Brunei Darussalam, Indonesia, the Philippines, Singapore and Thailand took part in the global competence assessment, and only Indonesia evaluated financial literacy (Table 3.2).

Table 3.1. Participation of Southeast Asian countries in PISA

\begin{tabular}{|c|c|c|c|c|c|c|c|c|}
\hline $\begin{array}{l}\text { Participation } \\
\text { in PISA cycles }\end{array}$ & $\begin{array}{c}\text { Brunei } \\
\text { Darussalam }\end{array}$ & Cambodia & Indonesia & Malaysia & Philippines & Singapore & Thailand & Viet Nam \\
\hline PISA 2000 & & & $x$ & & & & $x$ & \\
\hline PISA 2003 & & & $x$ & & & & $x$ & \\
\hline PISA 2006 & & & $x$ & & & & $x$ & \\
\hline PISA 2009 & & & $x$ & $x$ & & $x$ & $x$ & \\
\hline PISA 2012 & & & $x$ & $x$ & & $x$ & $x$ & $x$ \\
\hline PISA 2015 & & & $x$ & $x$ & & $x$ & $x$ & $x$ \\
\hline PISA 2018 & $x$ & & $x$ & $x$ & $x$ & $x$ & $x$ & $x$ \\
\hline PISA for Development & & $\mathrm{x}$ & & & & & & \\
\hline
\end{tabular}

All countries and economies in PISA 2018 distributed the student and school questionnaires. PISA 2018 also offered countries and economies four optional questionnaires for students (the educational career questionnaire, the information and communication technology (ICT) familiarity questionnaire, the well-being questionnaire, and the financial literacy questionnaire); an optional questionnaire for parents; and an optional questionnaire for teachers (both for reading teachers and for teachers of all other subjects). In the region, Brunei Darussalam and Thailand distributed the educational career questionnaire; Brunei Darussalam, Singapore and Thailand distributed the ICT questionnaire; and Malaysia distributed the teacher questionnaire (Table 3.2).

\section{Box 3.1. Cambodia's experience in PISA for Development}

PISA for Development (PISA-D) was a one-off pilot project that aimed to make the PISA assessment more accessible and relevant to middle- and low-income countries. The project re-designed the assessment and questionnaire instruments to capture a wider range of performance levels and social contexts. The project was also a contribution to the monitoring of international educational targets related to the Education Sustainable Development Goal (SDG), which was adopted by the United Nations General Assembly in 2015, as part of the Agenda for Sustainable Development.

Nine countries participated in PISA-D. In Cambodia, more than 5000 students in 170 schools participated in the assessment, representing about 37000015 -year-olds.

Cambodian students scored significantly below the OECD and ASEAN averages in all three domains (MoEYS, 2018). In comparison with PISA-D countries, the performance in mathematics ( 325 score points) was similar to the PISA-D average (324 score points), whereas the performance in reading (321 score points) was below the PISA-D average (346 score points). About $8 \%$ of students in Cambodia achieved the minimum level of proficiency in reading and $10 \%$ of students achieved the minimum level of proficiency in mathematics.

As in many other countries, girls outperformed boys in reading (by 17 score points), and students in urban schools outperformed those in rural schools (by 42 score points) (MoEYS, 2018). In addition, socio-economically advantaged students did considerably better in the assessment than disadvantaged students. For instance, advantaged students were about four times more likely than disadvantaged students to attain the baseline level of proficiency in mathematics.

Source: MoEYS (2018), Education in Cambodia: Findings from Cambodia's Experience in PISA for Development, Phnom Penh. 
Table 3.2. Features of the PISA 2018 participation of Southeast Asian countries

\begin{tabular}{|c|c|c|c|c|c|c|c|c|}
\hline & & Brunei Darussalam & Indonesia & Malaysia & Philippines & Singapore & Thailand & Viet Nam \\
\hline \multirow{2}{*}{$\begin{array}{l}\text { Format of the } \\
\text { assessment }\end{array}$} & Computer & $x$ & $x$ & $x$ & $x$ & $x$ & $x$ & \\
\hline & Paper & & & & & & & $x$ \\
\hline \multicolumn{9}{|c|}{ Global competence assessment } \\
\hline \multicolumn{2}{|c|}{$\begin{array}{l}\text { Financial literacy assessment } \\
\text { and questionnaire }\end{array}$} & & $\mathrm{x}$ & & & & & \\
\hline \multirow{5}{*}{$\begin{array}{c}\text { Optional } \\
\text { questionnaires }\end{array}$} & $\begin{array}{l}\text { Educational } \\
\text { career }\end{array}$ & $x$ & & & & & $x$ & \\
\hline & $\mathrm{ICT}^{1}$ & $x$ & & & & $x$ & $x$ & \\
\hline & Parent & & & & & & & \\
\hline & Teacher & & $x$ & & & & & \\
\hline & Well-being & & & & & & & \\
\hline \multicolumn{2}{|c|}{ Languages of the assessment } & English & Indonesian & nglish Malay & English & English & Thai & Vietnames \\
\hline
\end{tabular}

Note: 1. Information and communication technology.

Source: OECD, PISA 2018 Database.

\section{Performance in reading, mathematics and science}

Students' average performance in reading, mathematics and science is probably the most widely followed indicator from the PISA assessments. This indicator places most of the education systems in Southeast Asia clearly below the OECD average and neighbouring economies such as Beijing, Shanghai, Jiangsu and Zhejiang (B-S-J-Z) (China) and Chinese Taipei (Figure 3.1). On average across Southeast Asian countries, students scored 413 points in reading, 432 points in mathematics and 433 points in science. Countries and economies with a similar performance are mostly located in Latin America and Southeast Europe, such as Bulgaria, Colombia, Romania, Serbia and Uruguay (OECD, 2019c).

Figure 3.1. Performance in reading, mathematics and science Score points

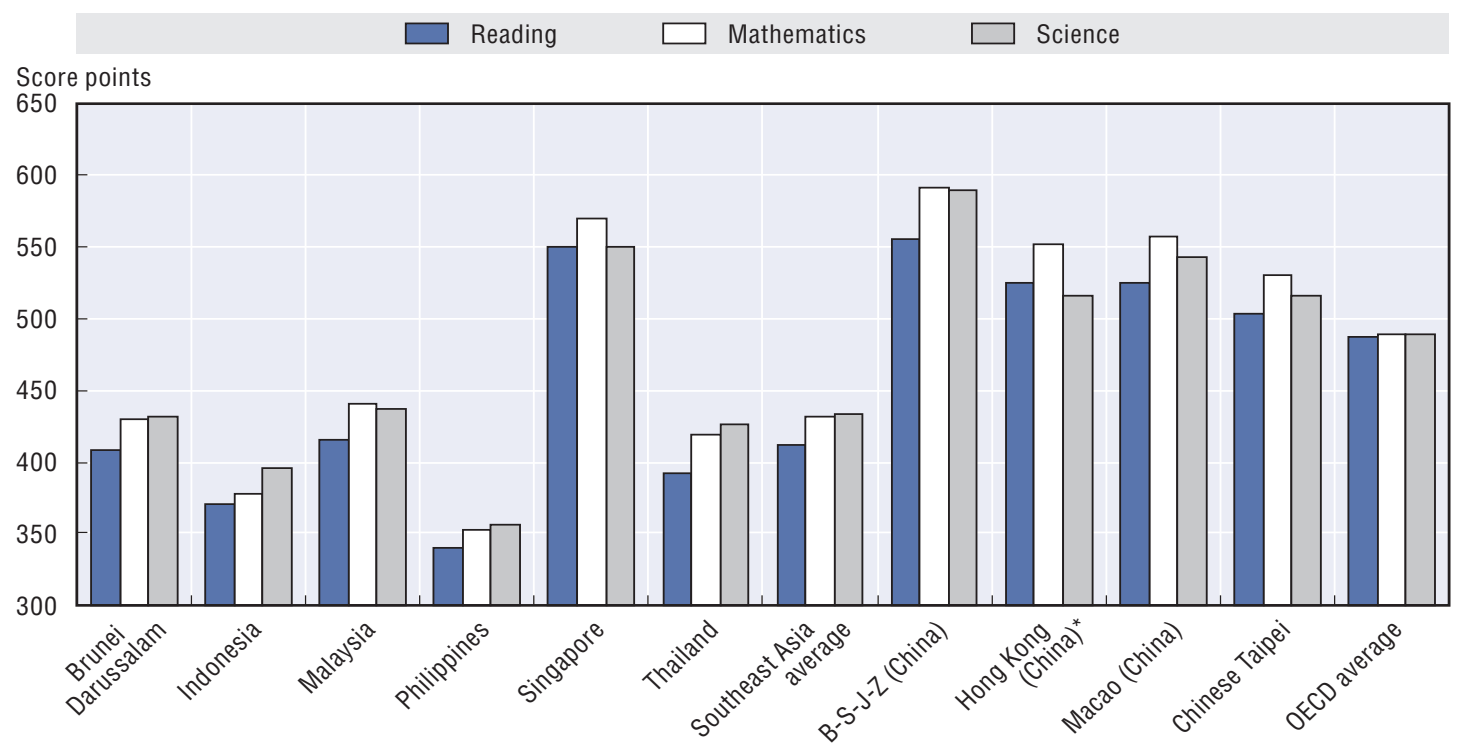

Note: * PISA 2018 data did not meet the PISA technical standards but were accepted as largely comparable. Source: OECD, PISA 2018 Database, Tables I.B1.4, I.B1.5 and I.B1.6.

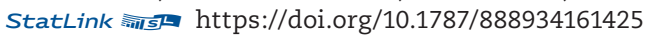

However, Southeast Asia's average hides wide differences among school systems. With average scores at least half a standard deviation above the OECD average, Singapore was 
one of the top-performing school systems in PISA 2018. Malaysia was the second highestperforming country in the region, followed closely by Brunei Darussalam and Thailand, and then by Indonesia and the Philippines.

However, PISA average scores need to be interpreted in context. For one thing, when interpreting PISA results with regard to the overall population of 15 -year-olds, sample coverage must be taken into consideration. In this regard, the share of the 15-year-old age cohort covered by PISA 2018 (Coverage Index 3, see [OECD, 2019c] for more details) in the region is somewhat lower than the share of 15-year-olds covered across OECD countries (OECD, 2019c). With under 70\% of 15-year-olds covered, the Philippines and Viet Nam had the lowest coverage rate in the region, followed by Malaysia and Thailand. In Indonesia, about $85 \%$ of 15 -year-olds were covered by the PISA sample, a laudable improvement from previous cycles - for instance, only $46 \%$ of 15 -year-olds were covered by the PISA 2000 sample. Finally, in Brunei Darussalam and Singapore, PISA results were representative of more than $95 \%$ of 15 -year-olds. In general, low coverage can be mainly attributed to 15 -year-olds who were no longer in the school system or were still enrolled in primary school and, to a lesser extent, to student exclusions from the test and dropout during the school year. Since these students are more likely to be academically weaker than those who remain (Spaull and Taylor, 2015), one should expect the relative standing of countries with a higher coverage of 15-year-olds, such as Brunei Darussalam and Singapore, to improve in the PISA rankings had all countries and economies covered the same proportion of 15-year-olds.

PISA 2018 results also need to be interpreted in light of the economic development of countries and economies. In fact, national income accounted for $44 \%$ of the difference in average reading scores (OECD, 2019c). Since school systems located in wealthier countries tend to score higher on PISA, one should expect the relative standing of Southeast Asia (except in Brunei Darussalam and Singapore) to improve had all countries and economies enjoyed the same per capita GDP. This is particularly the case for Indonesia and Thailand whose per capita GDP is amongst the lowest of all PISA-participating countries and economies. Along the same lines, accounting for students' socio-economic status shows that the average reading scores of the majority of school systems in the region improve significantly (OECD, 2019d). Indonesia's mean score in reading would jump from 371 to 401 score points, Thailand's from 393 to 423 score points, Malaysia's from 415 to 440 score points, Brunei's from 408 to 419 score points, and the largest improvement - from 340 to 383 score points - would be observed in the Philippines. By contrast, Singapore's reading performance would drop from 549 to 543 score points.

As in previous cycles, the reading scale for PISA 2018 was divided into a range of proficiency levels whose descriptors have been updated to reflect new aspects of reading that were assessed for the first time, such as assessing the quality and credibility of information and managing conflict among texts. In addition, PISA 2018 added easier items (Level 1c) that can better describe the capabilities of low-achieving students. The descriptors of the eight reading proficiency levels - Levels 1c, 1b, 1a, 2, 3, 4, 5 and 6, in ascending order of proficiency - can be found in Table I.5.1, OECD (2019c). Level 2 is considered the baseline level of proficiency, or the level at which students begin to demonstrate the skills that will enable them to fully participate in modern societies. At this level, students can identify the main idea in a text of moderate length; locate one or more pieces of information based on multiple, and partly implicit, criteria; reflect on simple visual features and the overall purpose of texts; and compare claims and evaluate the reasons supporting them based on short, explicit statements. According to this measure, approximately $47 \%$ of students across Southeast Asia scored above the baseline level of proficiency in reading, ranging from $19 \%$ in the Philippines to $89 \%$ in Singapore (Figure 3.2). In comparison, $77 \%$ of students across OECD countries, $82 \%$ in Chinese Taipei and 95\% in B-S-J-Z (China) scored above this baseline level. Better results were observed for mathematics and science, where on average $50 \%$ and $54 \%$ of students, respectively, across Southeast Asian economies scored above the baseline level of proficiency. 
Students who perform well on one section of the reading assessment also tend to perform well on other sections. However, students in some school systems perform relatively better on some areas of the assessments than on others, which may reflect differences in emphasis in the curriculum and teaching. For instance, regarding the main cognitive processes required to solve items (locating information; understanding; and evaluating and reflecting), Singaporean students scored relatively higher in the evaluating and reflecting process subscale; Malaysian and Indonesian students scored relatively lower on the understanding process subscale; students in Brunei Darussalam and Indonesia did relatively better on items that required students to locate information; and Thai students did relatively better on the understanding process subscale (OECD, 2019c). As regards the number of text sources required to construct the correct answer to items (single source or multiple source), Singaporean and Indonesian students scored relatively higher on the single source-text subscale, students in the Philippines did better on multiple texts, whereas students in all other countries in the region scored similarly on both subscales.

Figure 3.2. Proficiency levels in reading, mathematics and science

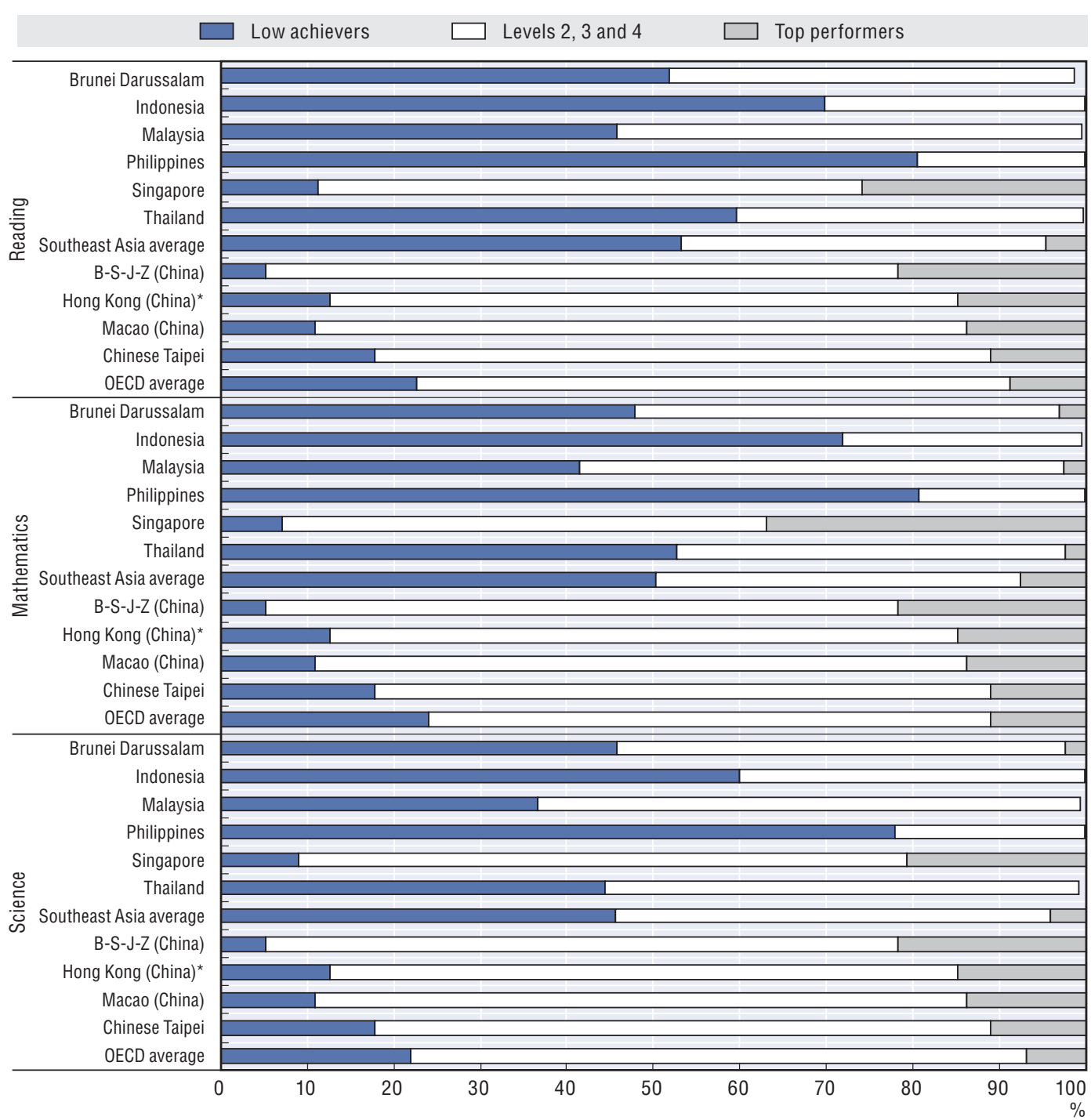

Note: * PISA 2018 data did not meet the PISA technical standards but were accepted as largely comparable. Source: OECD, PISA 2018 Database, Tables I.B1.1, I.B1.2 and I.B1.3.

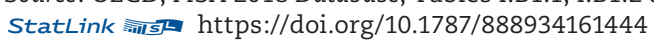


Students' performance in mathematics and science is particularly important in the context of digitalisation and ICT-related training and studies. Demand for ICT skills is growing in the region, and those who have these skills are earning higher wages. Good performance in science, technology, engineering and mathematics (STEM) will therefore be needed in Emerging Asian countries to ensure their ability to integrate the global economy, especially in the digital era (Box 3.2).

\section{Box 3.2. Preparing students for the digital era}

To be internationally competitive in the digital era, a skilled labour force is essential. According to the Economic Outlook for Southeast Asia, China and India 2020 (OECD, 2019a), Cambodia, Indonesia, and Thailand are all currently facing skilled labour shortages, which will remain high in 2021. Participants in the labour market will be required to expand and adapt their skills rapidly in response to the digital era. Schools need to focus more on STEM skills and literacy if students are going to achieve this goal. ICT and new technologies are changing the way societies interact, produce and create. Curriculum adjustments should be made in consultation with industry experts, so that training and the skills acquired reflect both current and future expected trends and industry demands.

Technical and vocational education and training (TVET) and lifelong learning play an important role in making digital education more inclusive. TVET programmes provide a mixture of theoretical and practical training that can prepare workers to meet industry demands. Southeast Asian countries typically begin offering TVET training as an alternative to general education at some point during secondary school. However, challenges remain since TVET is often viewed as a less desirable educational pathway than university or even a pathway of last resort for weaker students. These attitudes are reflected in the considerably lower proportion of students enrolled in TVET versus general education in Emerging Asian countries. Arrangements for transferring TVET credits to general education or visible efforts by prestigious employers to hire TVET graduates may help to enhance the public image of TVET training. Furthermore, TVET training typically requires many of the same literacy, numeracy, scientific, and technical skills necessary for general education options despite its perception as being an "easier" or less desirable option. Improving the image of TVET, while allowing for streamlined transfers to higher education, would be needed to maximise its role in providing digital and ICT skills and thus help prepare students and workers for the digital era.

Improvement in ICT infrastructure is required to support digital education, enhance TVET and lifelong learning programmes, which would also further leverage online education. Robust online training would provide the dynamism necessary for lifelong learning alongside paid work, rather than confining learning to an unemployed (or minimally employed) academic period. Continual upgrading of ICT skills while participating in the labour force would also protect workers against redundancy and obsolescence.

Source: OECD (2019a), Economic Outlook for Southeast Asia, China and India 2020: Rethinking Education for the Digital Era, OECD Publishing, Paris, https://doi.org/10.1787/1ba6cde0-en.

\section{Trends in performance}

PISA not only takes a snapshot of an education system's performance at a given moment; as a long-term study dating back to 2000 , PISA gives education systems an opportunity to see how their performance has evolved over the course of almost two decades. The first full assessment of each subject sets the scale and starting point for future comparisons. For reading results, it is possible to compare trends starting from 2000; mathematics was 
the major domain for the first time in 2003, and science in 2006. Comparing PISA 2018 performance with previous cycles is possible in only four countries in the region: Indonesia, Malaysia, Singapore and Thailand.

Indonesia has seen no significant long-term changes in students' performance in reading, mathematics and science (OECD, 2019c). In reading, Indonesia belongs to the group of countries with a hump-shaped trajectory, with performance improving during the first years, and becoming more negative over more recent years. However, given that Indonesia is the country where the coverage has improved the most since its first participation (from $46 \%$ to $85 \%$ of 15 -year-olds covered by the PISA sample), a stable performance over the years is an encouraging achievement. Indonesia's case shows that making an education system more inclusive does not necessarily work against the quality of the school system.

Malaysia has significantly improved in mathematics and science throughout its participation in PISA, but shows no significant change in reading (OECD, 2019c). Unlike in Indonesia, the share of 15 -year-olds covered by the PISA sample has decreased somewhat in PISA $2018-72 \%$ of students compared to $78 \%$ in 2009.

Since Thailand's first participation in PISA, mathematics and science performance have remained stable, whereas the average reading performance has dipped (OECD, 2019c). In reading, Thailand belongs to the group of countries with an increasingly negative trajectory, together with Korea and the Netherlands.

Despite already being a top-performing education system in its first participation, Singapore has improved its performance in reading and science even further (OECD, 2019c). Interestingly, not all students have improved in the same way: those at the top ( $90^{\text {th }}$ percentile) of the performance distribution saw their reading performance increase by almost 10 score points, whereas those at the bottom $\left(10^{\text {th }}\right.$ percentile) scored similarly in 2009 and 2018.

\section{Gender difference in performance and attitudes}

In recent decades, PISA results have consistently found that girls outperform boys in reading and, to a lesser extent, that boys outperform girls in mathematics, on average across all participating countries and economies (OECD, 2019d). Gender disparities in achievement are a matter of considerable concern, as they may have longterm consequences for girls' and boys' personal and professional future. Boys who lag behind and lack basic proficiency in reading may face serious difficulties in their further education, in the labour market and in everyday life. Equally, the under-representation of girls amongst top performers in science and mathematics can at least partly explain the persistent gender gap in careers in science, technology, engineering and mathematics (STEM) fields, which are often amongst the highest-paying occupations. Over the past few decades, many countries have made significant progress in narrowing, and even closing, the gender gap in educational attainment (OECD, 2019d). Gender-related disparities in achievement thus appear to be neither innate nor inevitable.

Even if girls outperformed boys in reading in every PISA-participating school system, the magnitude, pervasiveness and practical significance of the gender gap in student performance would vary across countries. On average across Southeast Asian countries, the gender gap was 28 score points, similar to the gender gap observed across OECD countries (30 score points) (Figure 3.3). The gender gap across Southeast Asian countries varied little (between 23 and 30 score points), except in Thailand where the gender gap stood at 39 score points. Interestingly, one of the narrowest gender gaps among all PISA-participating countries and economies was observed in B-S-J-Z (China) where girls outperformed boys by only 13 points. 
Figure 3.3. Gender gaps in reading and mathematics performance Score point gap (girls - boys)

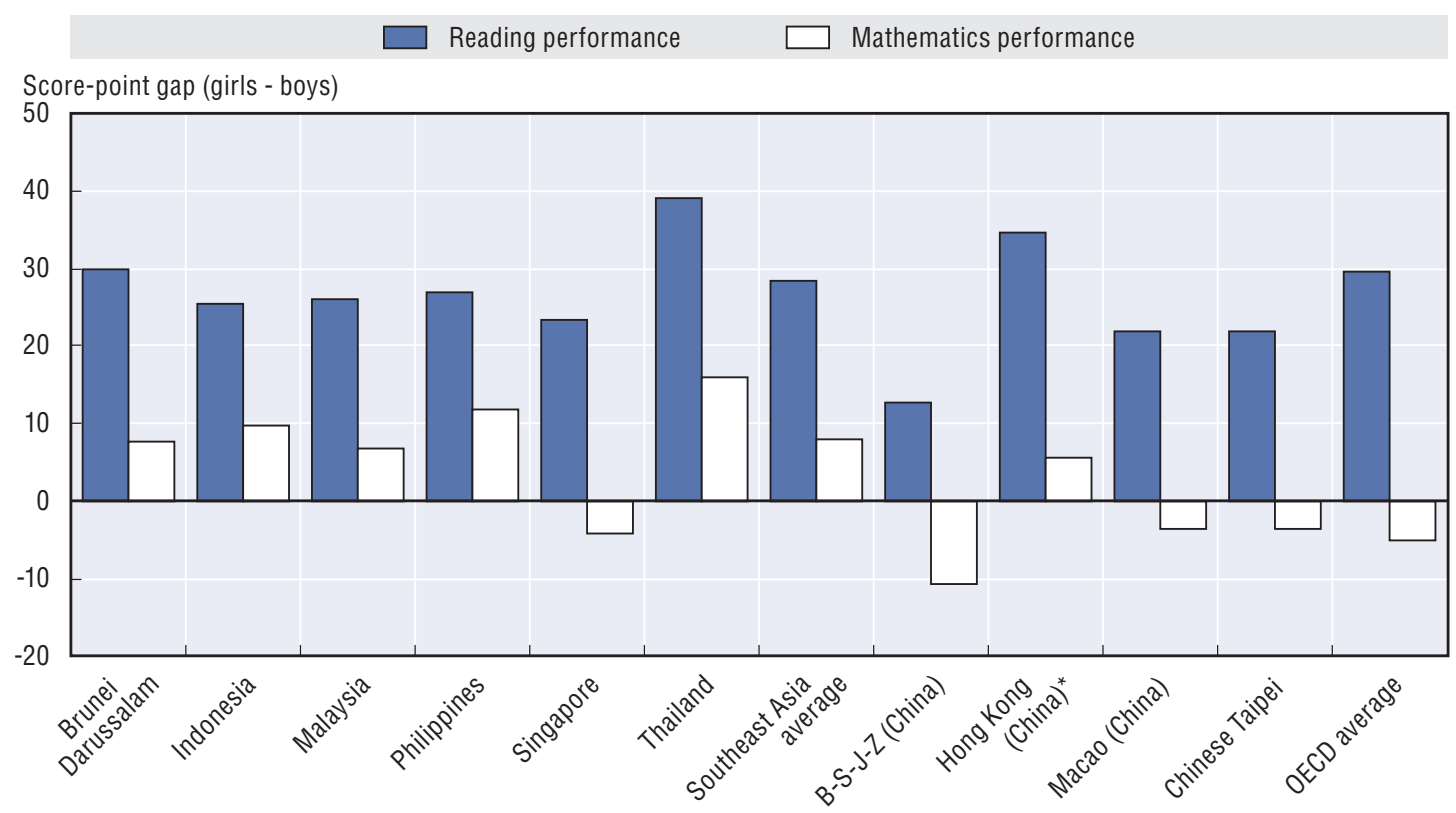

Note: * PISA 2018 data did not meet the PISA technical standards but were accepted as largely comparable. Source: OECD, PISA 2018 Database, Tables II.B1.7.1 and II.B1.7.3. StatLink inist https://doi.org/10.1787/888934161463

In mathematics, boys outperformed girls in about half of PISA-participating countries and economies, whereas girls outperformed boys only in a handful of school systems. On average across Southeast Asian countries, girls also outperformed boys in mathematics, by about 8 score points, whereas, on average across OECD countries, boys outperformed girls by 5 score points (Figure 3.3). The gender gaps among Southeast Asian countries ranged between 8 and 16 score points in favour of girls, except in Singapore where boys and girls performed similarly. By contrast, in B-S-J-Z (China) boys outperformed girls by almost 11 score points.

In Southeast Asian countries, just like in most other PISA-participating school systems, the variation in performance amongst boys was larger than amongst girls (OECD, 2019d). In reading, this finding results in boys being clearly overrepresented amongst low-achieving students, but not being underrepresented amongst top-performing students. The only exception was Singapore where boys were overrepresented amongst low-achieving students, and underrepresented amongst top-performing students. In mathematics, the larger variation in performance amongst boys often results in boys being overrepresented amongst top-performing students, but not being underrepresented amongst lowachieving students. This was the case, for instance, on average across OECD countries, in B-S-J-Z (China) and in Singapore, but not in all other Southeast Asian countries.

Gender gaps extend to other areas with regard to reading outcomes, such as reading enjoyment. PISA asked students to report whether they agree with the following statements about reading: "I read only if I have to"; "Reading is one of my favourite hobbies"; "I like talking about books with other people"; "For me, reading is a waste of time"; and "I read only to get information that I need". These items were combined to create the index of enjoyment of reading whose average is 0 and standard deviation is 1 across OECD countries. Positive values in the index mean that students enjoy reading more than the 
average student across OECD countries. According to this index, in all PISA-participating countries and economies, girls reported that they enjoyed reading to a greater extent than boys (OECD, 2019d). However, the gender gap in reading enjoyment is comparatively small in Southeast Asian countries. Whereas a 0.60 gender gap exists on average across OECD countries, the gender gap ranges from 0.16 in Indonesia to 0.58 in Brunei Darussalam. In fact, Indonesia, Thailand and Viet Nam were amongst the six countries with the narrowest gender gaps in reading enjoyment, together with B-S-J-Z (China), Japan and Korea.

Gender gaps also exist in other learning outcomes. Boys tend to display more competitive attitudes than girls, while girls tend to report greater motivation and perseverance, but also greater fear of failure (OECD, 2019d; OECD, 2019e). In relation to some of these findings, Southeast Asia was no exception. In all Southeast Asian countries, and especially in Malaysia, the Philippines and Thailand, girls reported greater motivation to master tasks than boys did. In all countries in the region, most notably in Brunei Darussalam and Singapore, girls expressed greater fear of failure than boys did. In other aspects, however, Southeast Asian countries were an exception. Brunei Darussalam, Indonesia and Malaysia were some of the few school systems where girls reported more competitive attitudes than boys did.

In most countries, men are underrepresented in "nurturing" roles, such as those in the healthcare, elementary education and domestic sectors, whereas women are underrepresented in high-status roles, such as leadership positions (Croft, Schmader and Block, 2015), and in the science, technology, engineering and mathematics (STEM) fields. Promoting more equal representation of men and women in different occupations is not only a way to reduce the gender gap in the labour market and improve gender equality, it is also a prerequisite for meeting the many challenges facing societies around the world. STEM jobs contribute to innovation and productivity growth; shortages of workers for these jobs are damaging to society.

PISA 2018 asked students about the level of education they expect to complete and what occupation they expect to be working in when they are around 30 years old. For the latter question, students could enter any job title or description in an open-entry field; their answers were classified according to the International Standard Classification of Occupations (ISCO-08). One may thus identify, for instance, "science and engineering professional" and "health professional" from amongst the career they cite.

On average across OECD countries in 2018, around 15\% of boys, but just $7 \%$ of girls, reported that they expect to work as science and engineering professionals when they are around 30 (Figure 3.4). In Southeast Asian countries too, more boys than girls expected to work in science and engineering occupations, but the gap varied considerably across countries. The largest gaps were reported in Malaysia, the Philippines and Singapore, whereas the narrowest gaps were observed in Indonesia and Thailand. The gaps were even larger with regard to the health sector, but this time in favour of girls. With a difference of between 13 and 20 percentage points in favour of girls, except in Viet Nam, the gender gap stands at a similar level to the 15 percentage points difference observed on average across OECD countries. 
Figure 3.4. Career expectations, by gender

Percentage of students

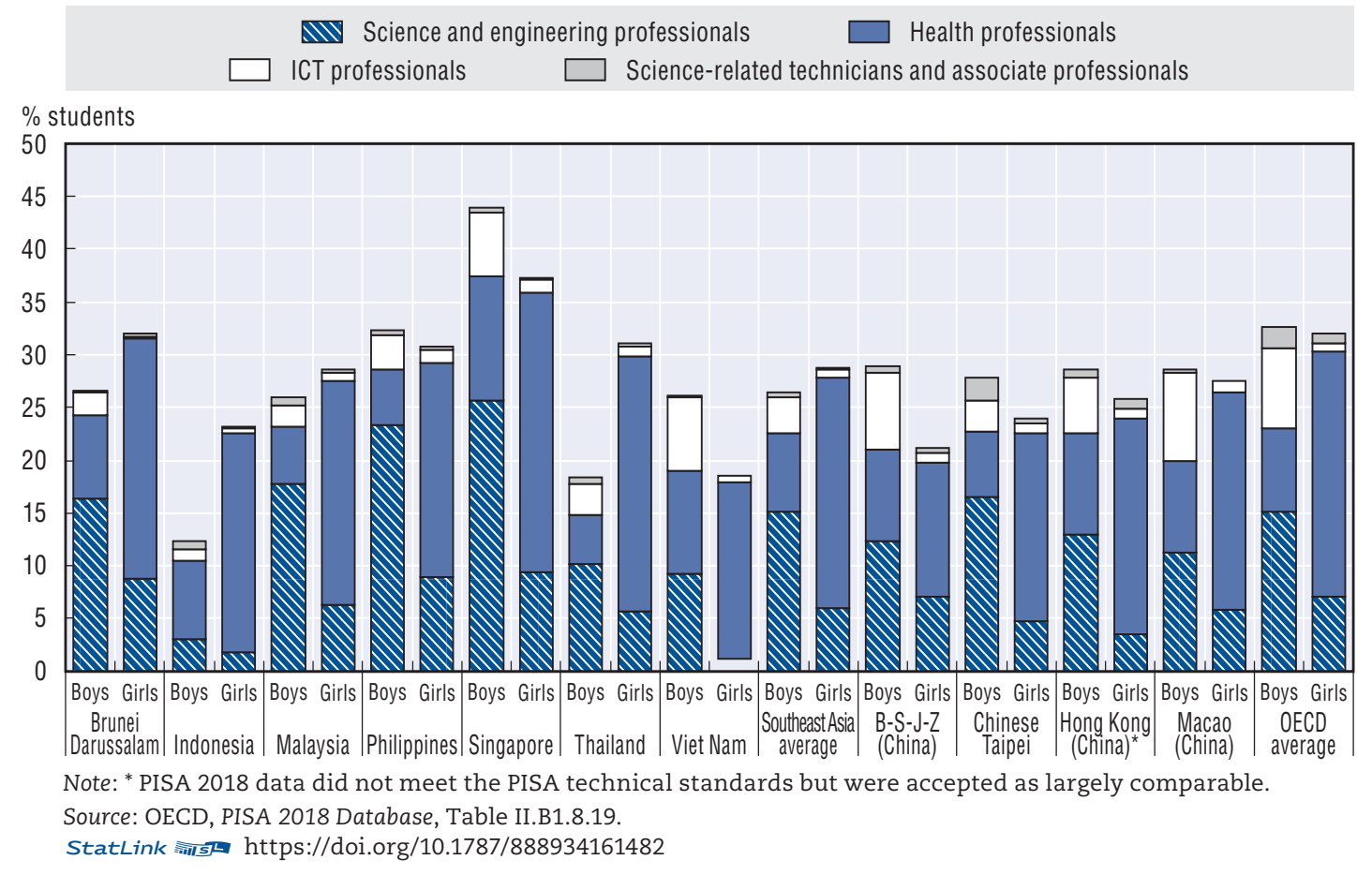

Gender difference in students' participation in ICT-related training and studies, including science and engineering, as well as in expectation of a future career, is to some extent related to the challenge of the gender digital divide facing the region (Box 3.3).

\section{Box 3.3. The gender digital divide in Emerging Asia}

Women still continue to face challenges with access to ICT in Emerging Asian countries, despite the efforts by policy makers to improve the situation. Women lag behind men in Internet access and usage, and continue to hold a lower proportion of places in academic and training programmes in STEM, TVET, or other ICT-related fields. Even in areas where women represent a majority of the students in higher education, they most often choose different career paths (OECD, 2019a).

Thus, it is important for countries to implement strategies to promote ICT as a career path that is open to and suitable for women and girls. Currently, some existing programmes in the region already encourage women and girls to gain exposure to ICT career opportunities and learn necessary technical skills. For instance, these initiatives may prepare girls to launch a start-up, whether or not they directly relate to ICT (e.g. India's WeTech Afterschool programme), or to improve the benefits of agriculture (e.g. Thailand). Thailand's Agritech Using ICT training programme helps women, youth, and other small rural landholders make educated agricultural decisions, including the integration of the latest agricultural technologies. The programme also includes entrepreneurship and digital skills training, so farmers can market and sell their produce effectively. Given the success of such programming, expansion to other countries should be a goal.

Source: OECD (2019a), Economic Outlook for Southeast Asia, China and India 2020: Rethinking Education for the Digital Era, OECD Publishing, Paris, https://doi.org/10.1787/1ba6cde0-en. 


\section{The socio-economic divide: Performance, attitudes and school resources}

Many modern societies suffer from rising inequality and low social mobility (OECD, 2018). Rising inequality and low social mobility not only threaten long-term growth (Cingano, 2014), but more fundamentally endanger social cohesion. Long-standing research finds that the most reliable predictor of a child's future success at school - and, in many cases, of access to well-paid and high-status occupations - is his or her family.

Children from low-income and low-educated families usually face many barriers to learning. A lower socio-economic and cultural status often translates into fewer educational resources, such as books, games and interactive learning materials at home, but also into a less stimulating home environment and weaker psychological support (Evans et al., 2010; Sirin, 2005; Thomson, 2018). However, results from previous rounds of PISA suggest that school systems may be able to help mitigate the impact of families' socio-economic status on their child's life outcomes (OECD, 2019d). Schools can channel resources to disadvantaged children and thus help create a more equitable distribution of learning opportunities and outcomes (Downey and Condron, 2016).

In PISA, a student's socio-economic status is measured by the PISA index of economic, social and cultural status (ESCS), a composite measure that combines into a single score the financial, social, cultural and human capital resources available to students. In PISA 2018, the three components that make up the index (parents' education, parents' occupation and the index of home possessions) were weighted equally. Looking at the relationship between the PISA index of economic, social and cultural status, and reading performance, one can observe that in all PISA-participating countries and economies a positive association exists (OECD, 2019d). As Figure 3.5 shows, this association is particularly strong in some Southeast Asian countries, including Brunei Darussalam (16\% of variance explained), Malaysia (16\%) and the Philippines (18\%). By contrast, the equity in reading performance in Singapore (13\% of variance explained) and Thailand (12\%) is similar to that observed across OECD countries (12\%) and B-S-J-Z (China) (13\%). With only $8 \%$ of variance in reading performance explained by students' socio-economic status, only Indonesia exhibited better equity outcomes than OECD countries in the region.

PISA consistently finds that some education systems manage to attain both academic excellence and equity (OECD, 2019d). Figure 3.5 shows that amongst the 25 school systems that scored above the OECD average in reading, about half of them exhibited positive equity outcomes. These include school systems like Australia, Canada, Estonia, Finland, Japan, Korea, Norway and the United Kingdom. Unfortunately, no education system in Southeast Asia attains both academic excellence and equity, and some of them (Brunei Darussalam, Malaysia and the Philippines) scored in the least desirable quadrant, where both academic performance and equity are below the OECD average.

How exposed are disadvantaged students to high-achieving students? PISA 2018 used the isolation index - i.e. the likelihood that a representative student of one group attends a school that enrols another group of students, ranging from 0 (no segregation) to 1 (full segregation) - to measure the exposure of disadvantaged students to high-achieving students. ${ }^{1}$ According to this measure, disadvantaged students in most Southeast Asian countries, and especially in the Philippines and Thailand, had fewer opportunities to interact with high-achieving students than the average student across OECD countries (OECD, 2019d).

In spite of the challenges they face, some disadvantaged students exhibit a remarkable capacity to reach adequate levels of academic achievement and social adjustment (Martin and Marsh, 2006). PISA refers to this capacity as academic resilience, which is operationalised as students who are in the bottom quarter of the PISA index of economic, 
social and cultural status (ESCS) in their own country/economy, but who score in the top quarter of reading performance in that country/economy. Academically resilient, students achieve educational excellence by national standards despite their socioeconomic disadvantage. In Brunei Darussalam, Malaysia, the Philippines and Singapore, less than $10 \%$ of disadvantaged students were academically resilient, compared to $11 \%$ on average across OECD countries, $12 \%$ in B-S-J-Z (China) and almost $20 \%$ in Macao (China) (Figure 3.6). By contrast, in Thailand and Indonesia as many as $13 \%$ and $14 \%$ were academically resilient, respectively.

\section{Figure 3.5. Strength of the socio-economic gradient and reading performance}

$\diamond$ Strength of the relationship between performance and socio-economic status is above the OECD average

$\diamond$ Strength of the relationship between performance and socio-economic status is not statistically significantly different from the average

Strength of the relationship between performance and socio-economic status is below the OECD average

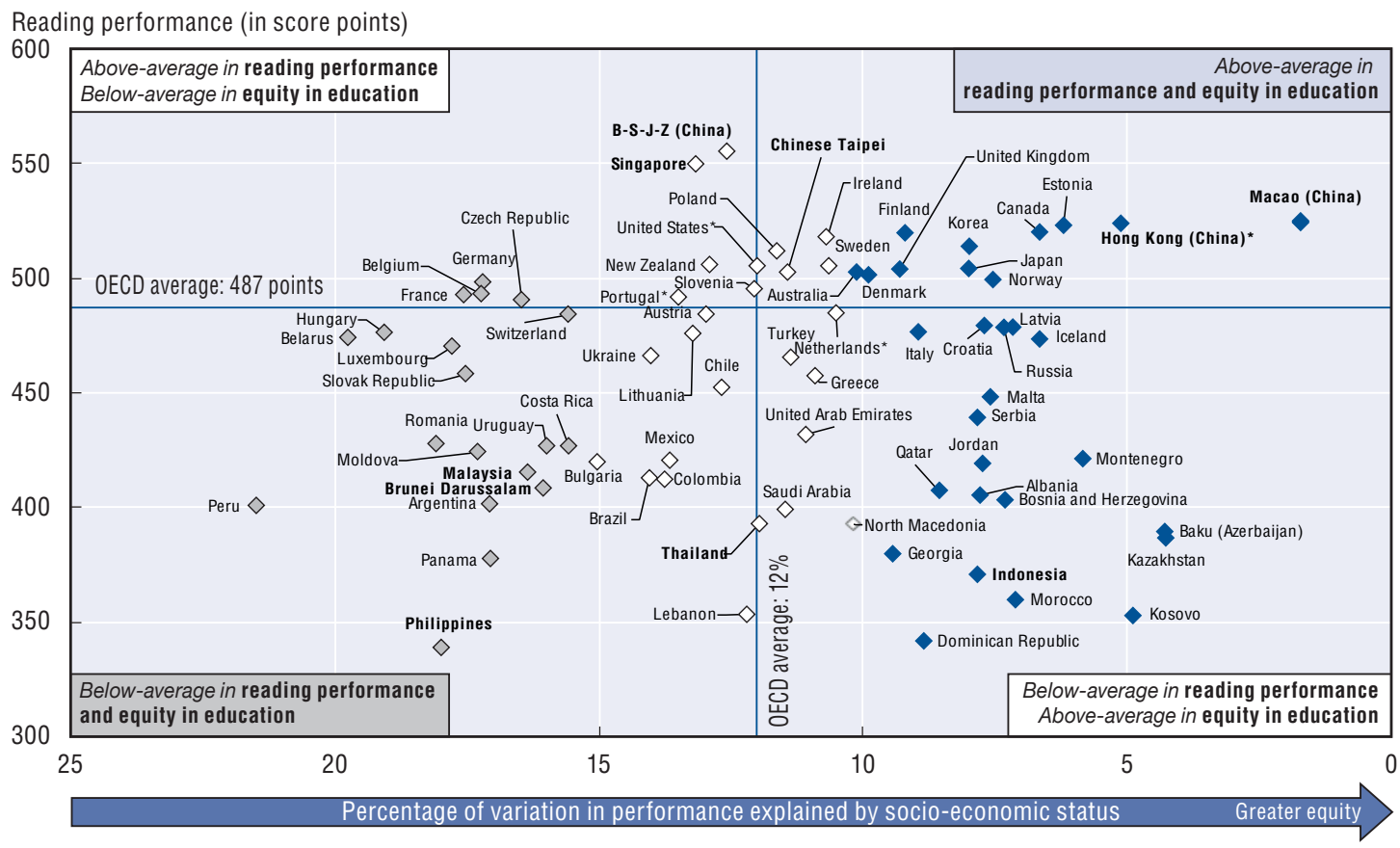

Notes: * PISA 2018 data did not meet the PISA technical standards but were accepted as largely comparable. Socioeconomic status is measured by the PISA index of economic, social and cultural status.

Source: OECD, PISA 2018 Database, Table II.B1.2.3.

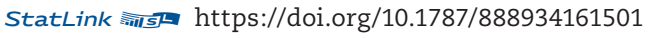

Socio-economically advantaged and disadvantaged students differ in attitudes and well-being indicators too. For instance, on average across OECD countries, advantaged students were more likely to feel satisfied with their lives, enjoy a greater sense of belonging at school and report higher levels of self-confidence, whereas disadvantaged students were more likely to report being bullied and to have skipped school (OECD, 2019e). Across Southeast Asian countries similar results were observed, but with notable exceptions. For instance, in Malaysia and Viet Nam, advantaged and disadvantaged students experienced similar levels of bullying, and Indonesia was one of three countries where bullying was more frequent amongst advantaged students. In Brunei Darussalam, Indonesia and Malaysia, no socio-economic gap existed in student truancy, whereas in the Philippines this gap was twice as large as the one observed on average across OECD countries. In Indonesia, no significant difference existed in sense of belonging at school between advantaged and disadvantaged students. As regards life satisfaction, no socio- 
economic gap existed in Indonesia, Thailand and Viet Nam. Regarding self-confidence, the Philippines had one of the largest socio-economic gaps (in favour of advantaged students) across all PISA-participating countries and economies.

Figure 3.6. Academic resilience in reading

Percentage of disadvantaged students who scored in the top quarter of reading performance in their own country

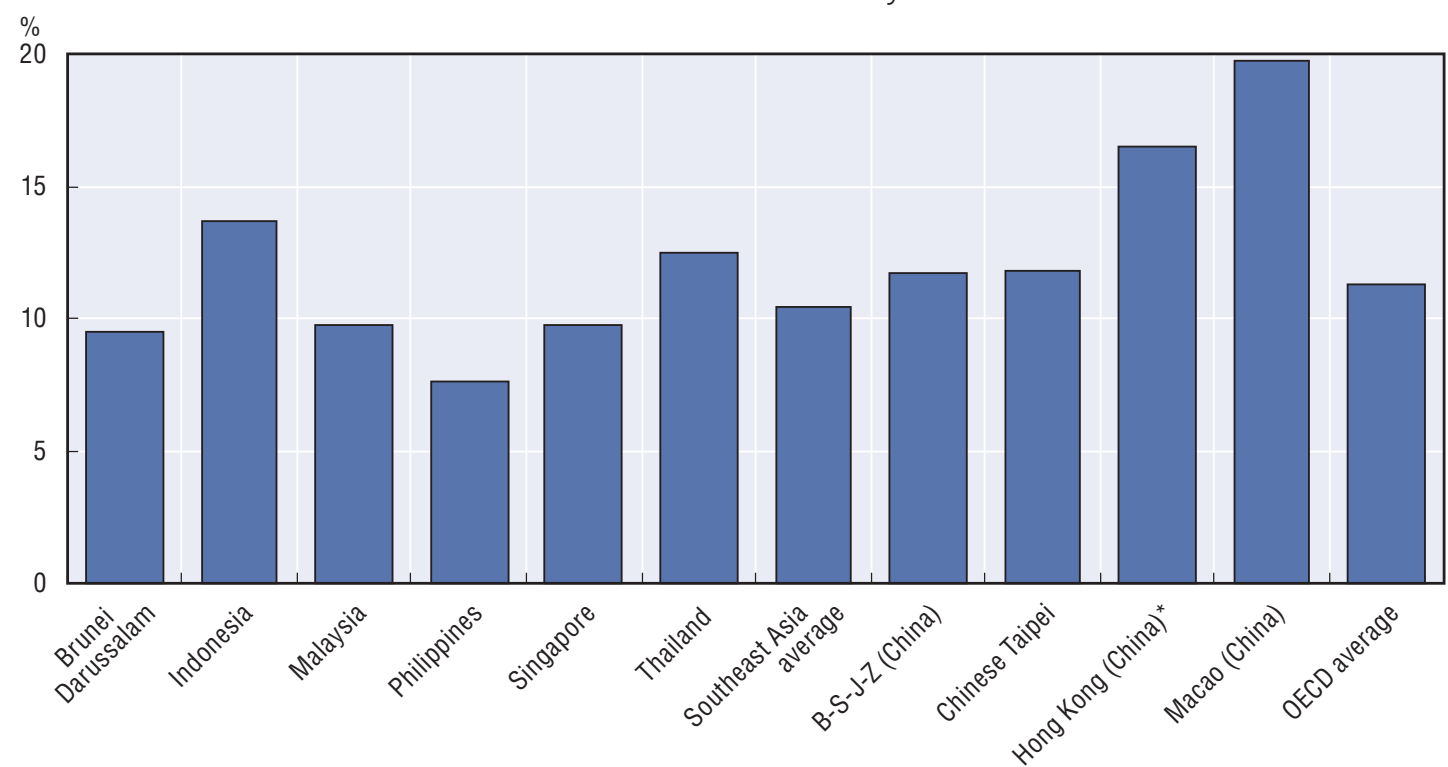

Note: * PISA 2018 data did not meet the PISA technical standards but were accepted as largely comparable. Source: OECD, PISA 2018 Database, Table II.B1.3.1.

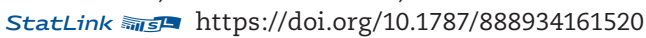

Disadvantaged students face considerable barriers to navigating and succeeding academically, many of which relate to their home environment but some are also linked to the high concentration of disadvantaged students in certain schools. These schools, for instance, may find difficulties in attracting, and especially retaining, the most effective and experienced teachers. According to the most recent OECD Teaching and Learning International Survey (TALIS), conducted in 2018, in most countries, teachers with only a few years of experience tend to work in schools that have higher concentrations of disadvantaged students (OECD, 2019f). Some school systems may partially compensate for this challenge by providing additional material and human resources to the most disadvantaged schools, or offering incentives to the best teachers to work and stay in the schools where they are most needed.

PISA 2018 measured the allocation of material and human resources to schools by asking school principals the extent ("not at all", "very little", "to some extent", "a lot") to which their capacity to provide instruction in their schools was hindered by a lack of the following resources (or if they were of insufficient quality): teaching staff, assisting staff, educational material and physical infrastructure. Both shortage of education material" and "education staff" were constructed based on school principals' responses to this question. The socio-economic gaps in these indices suggest that some school systems in Southeast Asia can do a better job at compensating disadvantaged schools (Figure 3.7). For instance, Thailand, the Philippines and, to a lesser extent, Indonesia were amongst the education systems in PISA 2018 with the largest gaps in both material and human resources between advantaged and disadvantaged schools. By contrast, in Brunei Darussalam, the socio-economic gap in these resources was just above those observed on 
average across OECD countries, and Malaysia, Singapore and Viet Nam exhibited a socioeconomic gap only in material resources.

The difference in access and allocation between schools with different socioeconomic profiles also appears in ICT infrastructure and tools in some countries in the region (Box 3.4).

\section{Figure 3.7. Difference in shortage of educational material and staff, by schools' socio-economic profile \\ Results based on principals' reports}

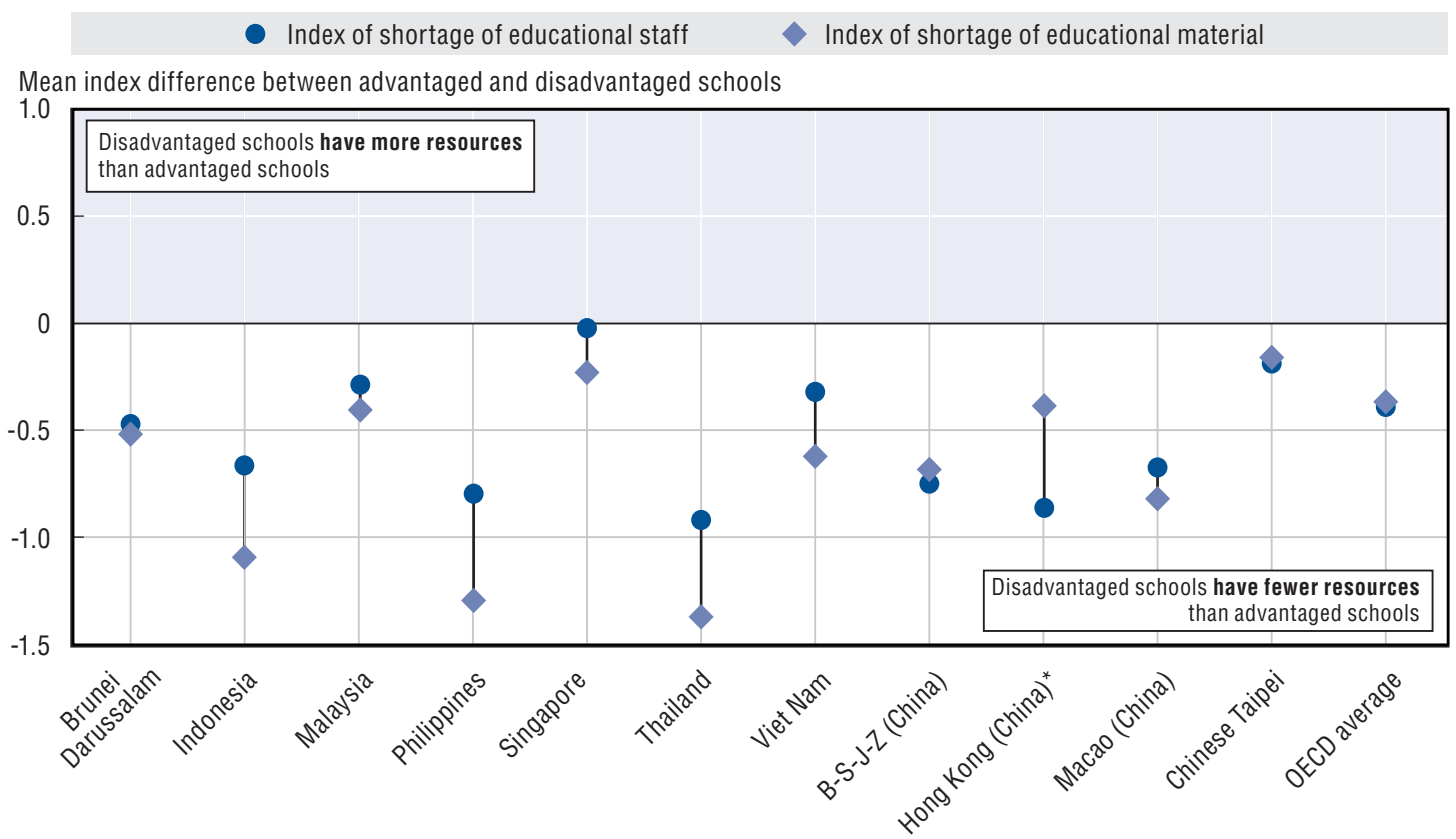

Notes: * PISA 2018 data did not meet the PISA technical standards but were accepted as largely comparable. Statistically significant differences are shown in a darker tone. The socio-economic profile is measured by the school's average PISA index of economic, social and cultural status (ESCS). For this analysis, the sample is restricted to schools with the modal ISCED level for 15-year-old students.

Source: OECD, PISA 2018 Database, Tables II.B1.5.13 and II.B1.5.14.

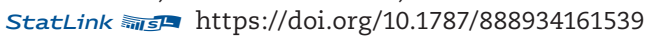

\section{Box 3.4. Socio-economic divide in students' ICT access}

ICT access remains an issue for schools in many Emerging Asian countries. This may be due to a lack of access to computers, such as in Indonesia (OECD, 2019a), or Internet access, as seen in Myanmar (OECD, 2019a). Indonesia also experiences a significant socioeconomic gap in ICT infrastructure based on the statuses of the communities where schools are located. According to Students, Computers and Learning: Making the Connection (OECD, 2015), Indonesia experienced a gap of over $25 \%$ in access to computers with an Internet connection between schools with students of high socio-economic backgrounds and those with students of low socio-economic backgrounds. In contrast, the gaps are less than 20\% in Viet Nam, 10\% in Malaysia and less than 5\% in Singapore. The high and low socio-economic backgrounds are defined as students being in the top and bottom quartiles of the PISA index of economic, social, and cultural status (ESCS). Programmes to bridge the divide in Indonesia (e.g. the Jardiknas and SchoolNet programmes) have been successful so far, but the country will need to continue paying close attention to reducing the gap and maintaining stable funding for the programmes (OECD, 2019a). 


\section{Box 3.4. Socio-economic divide in students' ICT access (cont.)}

Myanmar has more widespread access issues, as merely $27.4 \%$ of primary schools and $59.3 \%$ of lower secondary schools have access to electricity, which leads to difficulties in using ICT at school (UNESCO, 2019; OECD, 2020). In addition, less than $1 \%$ of primary schools have access to computers or the Internet (UNESCO, 2019). 4G Internet coverage is widespread (with $90 \%$ of Myanmar now covered), although using the web in classrooms does not appear to be an urgent priority.

Moreover, digital illiteracy of teachers is a pervasive issue in both of these countries, regardless of ICT access. The uneven classroom use of ICT by teachers remains a challenge in the country, particularly in rural and remote areas. However, efforts have been made to address this issue through various programmes, including the "Universal Service Obligation" in which the government provides training for teachers in remote areas. In Myanmar, what little ICT equipment is available often sits idle, as teachers do not know how to use it. Both Indonesia and Myanmar have programmes working to remedy the issue that must receive continued support.

Source: OECD (2019a), Economic Outlook for Southeast Asia, China and India 2020: Rethinking Education for the Digital Era, OECD Publishing, Paris, https://doi.org/10.1787/1ba6cde0-en.

\section{School climate}

A positive school climate is hard to define or measure, but easy to recognise. The state of the school's facilities, the tone of the conversations in corridors, the enthusiasm of the school staff and the way students interact during breaks are some of the signs that visitors can interpret quickly and thus broadly assess a school's climate. A safe, supportive and healthy school climate can make a great difference in students' lives. A positive academic environment, for instance, can promote students' scholastic achievement, well-being and self-esteem (Hoge, Smit and Hanson, 1990; MacNeil, Prater and Busch, 2009; Way, Reddy and Rhodes, 2007) and some of these effects persist for years (Hoy, Hannum and Tschannen-Moran, 1998).

The 15-year-old students who sit the PISA assessment may not evaluate their school climate as consciously as adults do, but they certainly feel it. All students appreciate a school environment where bullying is unusual, making friends is relatively simple, and establishing genuine and respectful relationships with teachers is the norm - even if students cannot always put their feelings into words. While PISA 2018 cannot cover all the dimensions of school climate, the student and school questionnaires distributed with the assessment include more than 20 questions directly related to school climate. In this section, the following aspects of school climate will be examined: bullying, disciplinary climate, student truancy and sense of belonging at school.

PISA asked students how often during the 12 months prior to the PISA test they had a series of experiences related to physical, verbal and relational bullying, such as someone making fun of them, getting pushed around or hit by other students, and leaving them out of things on purpose. Combining these statements into a single indicator, "any type of bullying act", shows that students in all Southeast Asian countries were more frequently victimised, on average, compared with students across OECD countries or in B-S-J-Z (China) (Figure 3.8). With more than half of students saying that they had been bullied at least a few times a month, the results for Brunei Darussalam and the Philippines are particularly alarming. Almost as troubling were the results in Indonesia and Malaysia, where $41 \%$ and $36 \%$ students, respectively, reported being bullied at least a few times a month. As a matter of comparison, the equivalent share across OECD countries, B-S-J-Z (China) and Chinese Taipei was $23 \%, 18 \%$ and $13 \%$, respectively.

The results are more encouraging regarding the disciplinary climate in language-ofinstruction lessons for the region, except maybe in the Philippines (OECD, 2019e). PISA asked students how frequently a series of things happen in their language-of-instruction 
lessons, such as students not listening to the teacher, or making noise and creating disorder. The index of disciplinary climate was built using students' responses to this question, according to which Indonesia, Thailand, and especially Viet Nam, exhibited amongst the most positive disciplinary climate in PISA 2018, together with East Asian and East European education systems. For instance, in Viet Nam, about $4 \%$ of students reported that, in every language-of-instruction lesson, the teacher has to wait a long time for students to quiet down, compared to $9 \%$ on average across OECD countries and 15\% of students in the Philippines (Figure 3.8). With values in the index of disciplinary climate to close or just above the OECD average, Brunei Darussalam, Malaysia and Singapore probably do not need to consider the disciplinary climate in schools as an area of special concern (OECD, 2019e).

The findings on truancy are also encouraging for Southeast Asia. On average across countries in the region, 19\% of students reported having skipped a whole day of school, compared to $21 \%$ of students on average across OECD countries, but only $1 \%$ of students in B-S-J-Z (China) (Figure 3.8). There are large variations across countries in the region. Truancy was comparatively low in Brunei Darussalam, Malaysia, Singapore and Viet Nam; similar to the OECD average in Indonesia; and comparatively high in Thailand and, to a lesser extent, in the Philippines.

Figure 3.8. Indicators of school climate Percentage of students

$\square$ Reported being bullied at least a few times a month
Reported that the teacher has to wait a long time for students to quiet down in every lesson
Agreed or strongly agreed that they feel lonely at school

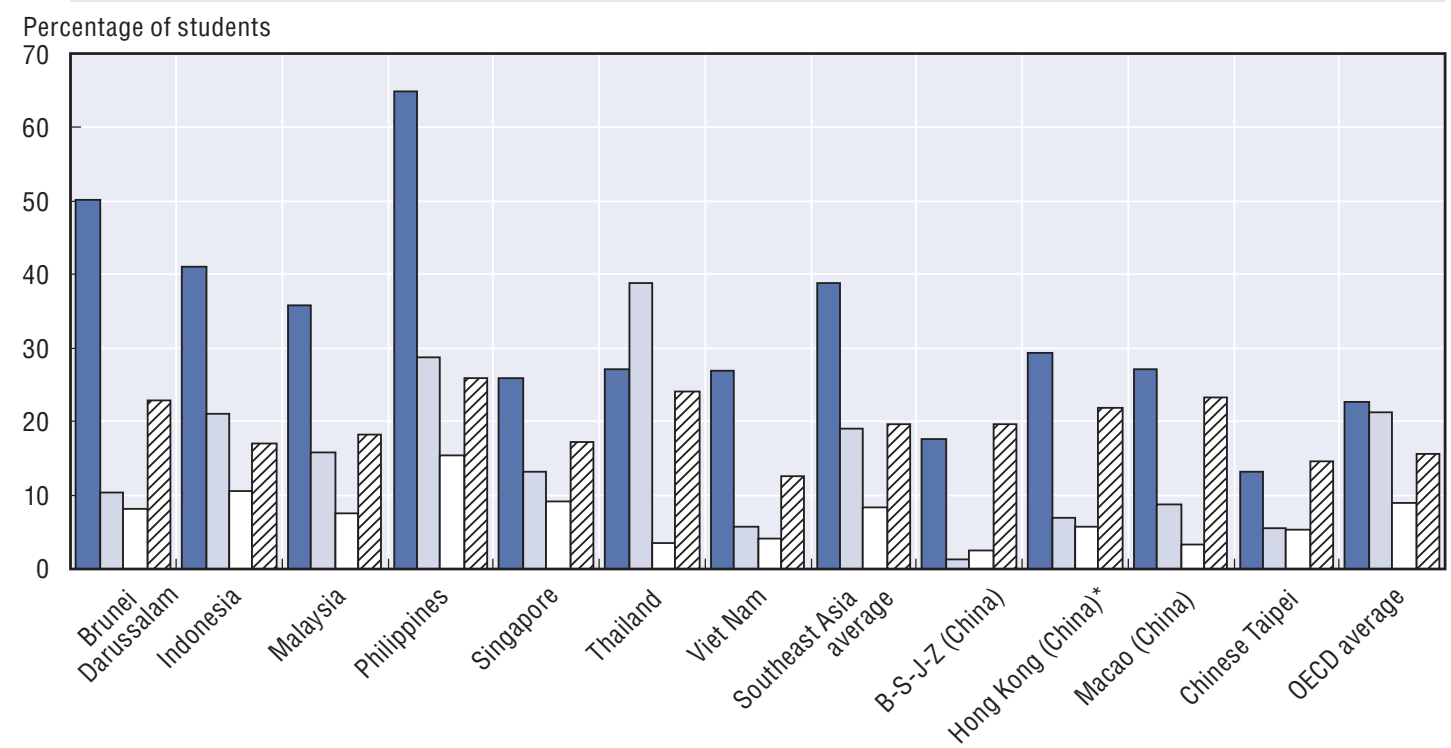

Note: * PISA 2018 data did not meet the PISA technical standards but were accepted as largely comparable. Source: OECD, PISA 2018 Database, Tables III.B1.2.1, III.B1.3.1, III.B1.4.1 and III.B1.9.1.

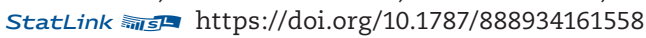

Students in Southeast Asia reported a comparatively weak sense of belonging at school (OECD, 2019e). PISA 2018 asked students how much they agree with a series of statements about their school, including if they feel lonely at school or feel they belong at school. Based on the index of sense of belonging calculated from students' responses to this question, students in all countries in Southeast Asia reported a somewhat weaker sense of belonging at school than the average student across OECD countries. For instance, about $20 \%$ of students in the region - ranging from $13 \%$ in Viet Nam to $26 \%$ in 
the Philippines - agreed or strongly agreed that they feel lonely at school, compared to $16 \%$ on average across OECD countries (Figure 3.8). However, the findings for other items were more promising. For instance, $81 \%$ of students in the region agreed or strongly agreed that they make friends easily at school, compared to $75 \%$ of students across OECD countries and $79 \%$ in B-S-J-Z (China) (OECD, 2019e).

\section{Student well-being}

Many of the education systems participating in PISA not only want to know how their students fare academically, but also how they get on with their lives. Indeed, 15-yearold students are in a key transition phase of physical and emotional development, and schools play a major role in how satisfied and happy students are with their lives (Rees and Main, 2015). After all, adolescents spend a large part of their time at school. In this regard, PISA 2018 data show that one of the best predictors of student happiness was how satisfied they were with their life at school (OECD, 2019e). Parents also seem to know this as they overwhelmingly cite school safety, good reputation and a pleasant environment as the most important criteria they consider when choosing a school for their children (OECD, 2015).

Overall, students in the Southeast Asian countries reported satisfactory levels of well-being, though with large variations within the region (Figure 3.9). On average across countries in the region, about $65 \%$ of students reported being satisfied with their lives (7-10 in the life-satisfaction scale), compared to $67 \%$ across OECD countries and 59\% in B-S-J-Z (China). However, in Brunei Darussalam only $42 \%$ were satisfied with their lives, the lowest percentage across all PISA-participating countries and economies. About $92 \%$ of students on average across Southeast Asian countries - ranging from $85 \%$ in Viet Nam to $95 \%$ in the Philippines - said they were sometimes or always happy, whereas $91 \%$ of students across OECD countries reported they were happy. As for fear of failure, a larger share of students in the region are more afraid of the consequences of failing than on average across OECD countries, and especially in Brunei Darussalam, Malaysia and Singapore (OECD, 2019e). For instance, $73 \%$ of students in Singapore were afraid that failing might signal a lack of talent, compared to $55 \%$ on average across OECD countries and 53\% in B-S-J-Z (China).

Figure 3.9. Students' well-being Percentage of students

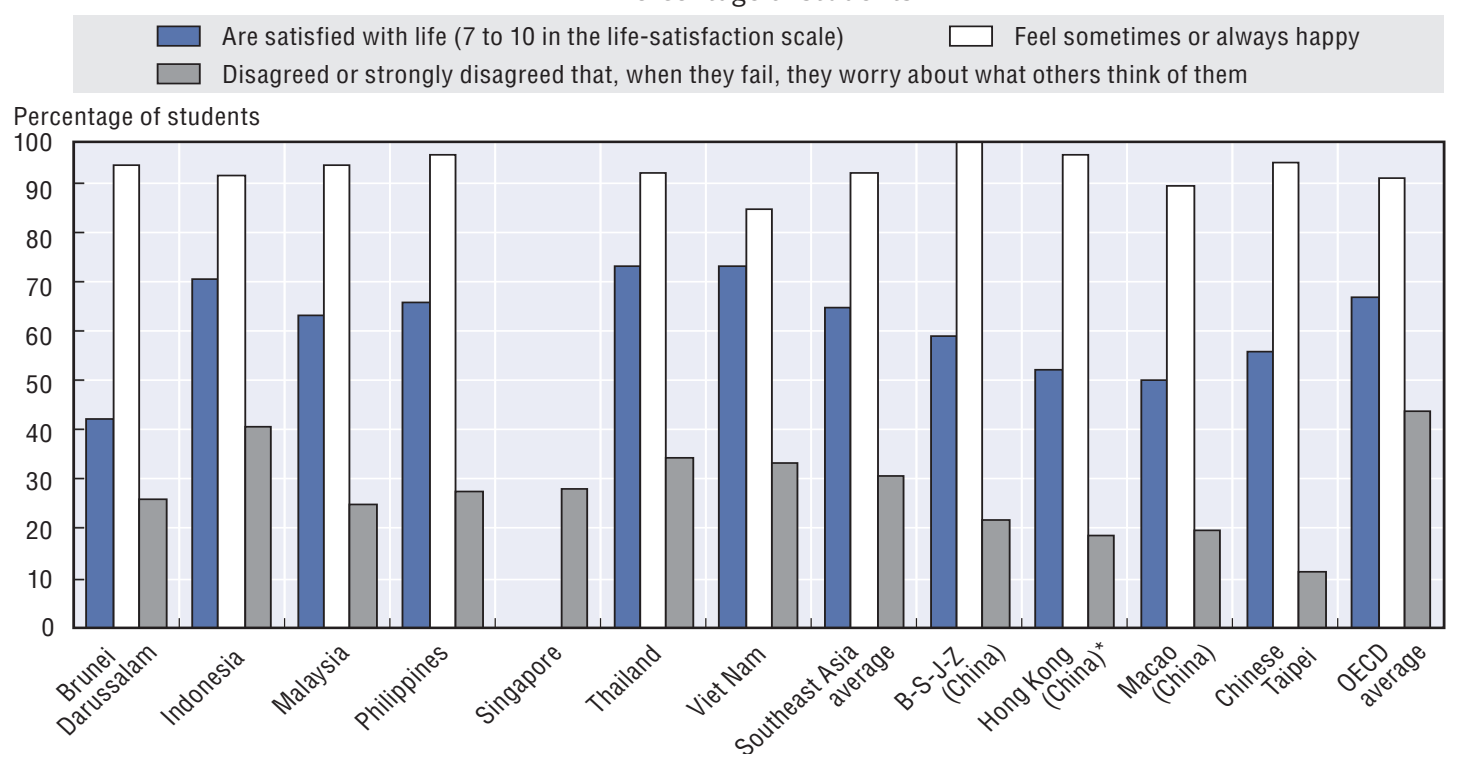

Note: * PISA 2018 data did not meet the PISA technical standards but were accepted as largely comparable. Source: OECD, PISA 2018 Database, Tables III.B1.11.1, III.B1.12.1 and III.B1.13.2.

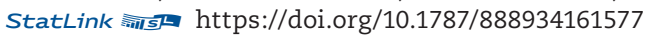




\section{Teaching strategies}

Previous analyses of PISA data have shown that teachers in mathematics and science across the globe vary considerably in what they teach and, more importantly, in how they teach (Echazarra et al., 2016; Mostafa, Echazarra and Guillou, 2018). To determine how language-of-instruction teachers teach, PISA 2018 asked students several questions about the type of strategies their teachers use in their lessons. Their responses to these questions were combined to build six indices about teacher practices. These indices and examples of the questions that compose them are provided in Table 3.3.

Table 3.3. Indices of teacher practices

\begin{tabular}{|c|c|c|}
\hline Index name & Student prompt & Example questions \\
\hline $\begin{array}{l}\text { - Teacher } \\
\text { enthusiasm }\end{array}$ & $\begin{array}{l}\text { Do you agree ("strongly agree", "agree", } \\
\text { "disagree", "strongly disagree") with } \\
\text { the following statements about the two } \\
\text { language-of-instruction lessons you } \\
\text { attended prior to sitting the PISA test }\end{array}$ & $\begin{array}{l}\text { - It was clear to me that the teacher liked teaching us } \\
\text { - The enthusiasm of the teacher inspired me }\end{array}$ \\
\hline - Teacher support & \multirow{5}{*}{$\begin{array}{l}\text { How often ("never or hardly never", "some } \\
\text { lessons", "most lessons", "every/all } \\
\text { lesson(s)") do the following happen in your } \\
\text { language-of-instruction lessons }\end{array}$} & $\begin{array}{l}\text { - The teacher shows an interest in every student's learning } \\
\text { - The teacher gives extra help when students need it }\end{array}$ \\
\hline - Teacher feedback & & $\begin{array}{l}\text { - The teacher gives me feedback on my strengths in this subject } \\
\text { - The teacher tells me in which areas I can improve }\end{array}$ \\
\hline $\begin{array}{l}\text { - Teacher-directed } \\
\text { instruction }\end{array}$ & & $\begin{array}{l}\text { - The teacher asks questions to check whether we have understood } \\
\text { what was taught } \\
\text { - The teacher tells us what we have to learn }\end{array}$ \\
\hline $\begin{array}{l}\text { - Stimulation } \\
\text { of reading } \\
\text { engagement }\end{array}$ & & $\begin{array}{l}\text { - The teacher encourages students to express their opinion about a text } \\
\text { - The teacher helps students relate the stories they read to their lives }\end{array}$ \\
\hline $\begin{array}{l}\text { - Adaptive } \\
\text { instruction }\end{array}$ & & $\begin{array}{l}\text { - The teacher adapts the lesson to [my] class's needs and knowledge } \\
\text { - The teacher changes the structure of the lesson on a topic that most } \\
\text { students find difficult to understand }\end{array}$ \\
\hline
\end{tabular}

All indices have been standardised so that their averages are 0 and standard deviations are 1 across OECD countries. Positive values in the indices mean that students perceived their language-of-instruction teachers to be more enthusiastic, provide greater support or use certain teaching practices more frequently than the average student across OECD countries did. To account for differences in response style across countries and economies, the values of each index have been adjusted using the average response across all indices. These adjusted results are shown in Figure 3.10, which represents the extent to which one teacher practice is more frequently used relative to both other countries and other practices.

On average across Southeast Asian countries, students reported that their languageof-instruction teachers employed teacher-directed instruction more frequently and provided somewhat more support than the average OECD student did (Figure 3.10). By contrast, teachers in the region used adaptive instruction and stimulated reading engagement less frequently than did teachers on average across OECD countries, at least according to students' reports.

All education systems in the region share a comparatively high frequency of teacherdirected instruction and low frequency of adaptive instruction, except for Singapore. In Singapore, the only top-performing school system in the region, teacher-directed practices were relatively infrequent, whereas adaptive instruction, and also teacher feedback, were comparatively common. In many other high-performing systems, teachers also adapt their teaching to students' needs and level of understanding relatively frequently. By contrast, teacher-directed instruction is a common feature of systems with comparatively low average scores on the PISA assessment. 
Figure 3.10. Teaching practices in language-of-instruction lessons

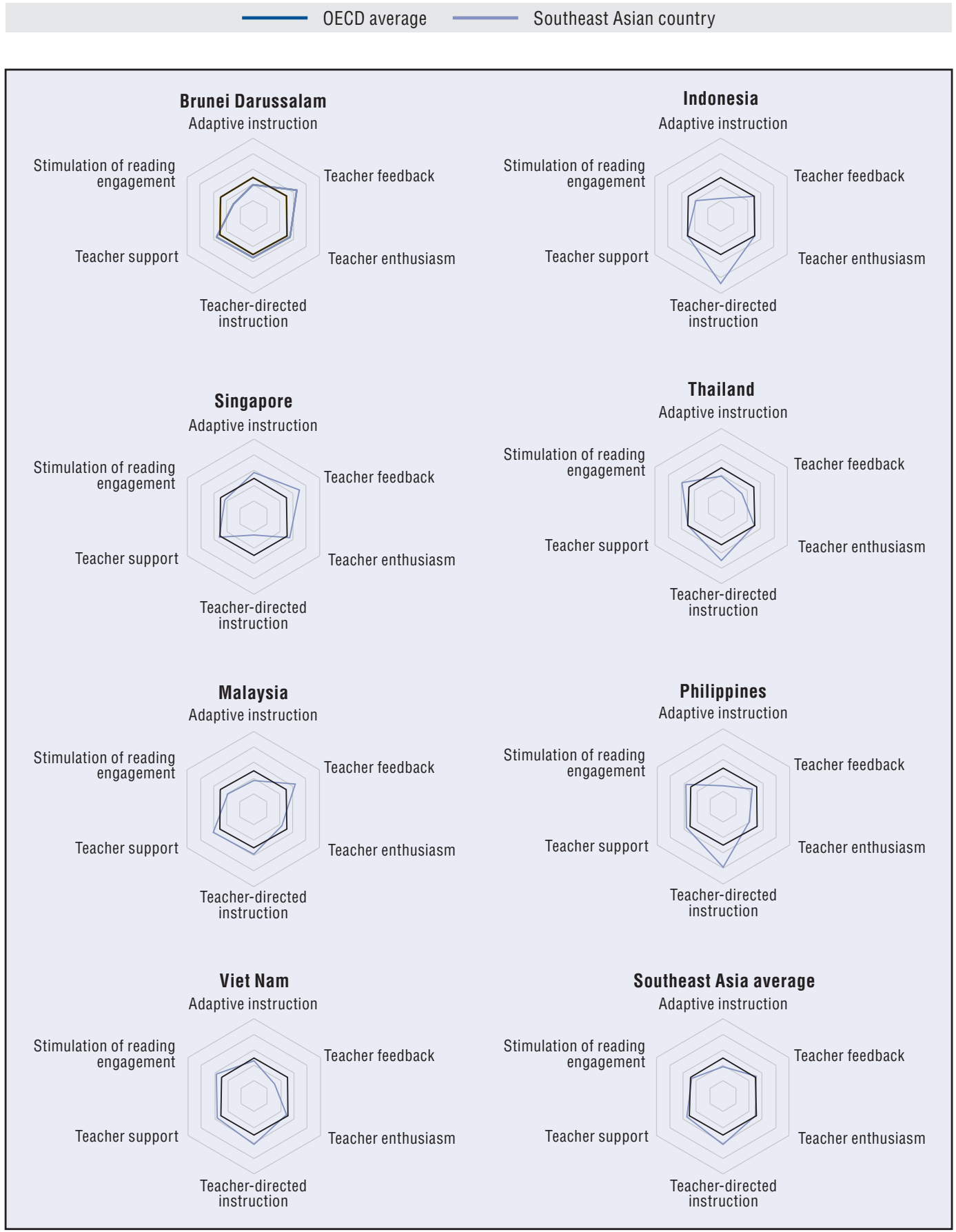

Source: OECD, PISA 2018 Database.

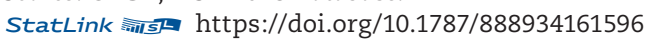

In the region, and always according to students' reports, teacher support was relatively most common in Malaysia; teacher feedback and adaptive instruction were most frequent in Singapore; teacher enthusiasm was most frequently observed in Brunei Darussalam; teacher-directed instruction was most common in Indonesia; and the stimulation of reading engagement was most frequently employed in Thailand. 
Another area where the education systems in Southeast Asia can still improve is the meta-cognitive skills of students in reading. Meta-cognitive skills can be defined as the strategies that students use to take charge of their own learning in a meaningful way (Kim, Park and Baek, 2009) or, more concretely, the awareness and ability to use appropriate strategies when processing texts (OECD, 2019b). In reading, these strategies include setting learning goals, adapting one's reading strategies, monitoring and solving comprehension problems, summarising a piece of text and remembering essential information (OECD, 2019b). Meta-cognition is important for students' learning outcomes. Previous studies have shown that students improve their reading skills faster when they are taught meta-cognitive strategies (Artelt, Schiefele and Schneider, 2001; Baker and Beall, 2009) and these strategies may be particularly helpful for students with learning problems (Kim, Park and Baek, 2009).

In PISA 2018, students were asked about the usefulness of a series of strategies, such as underlining, reading aloud, summarising and memorising, for different types of reading tasks (understanding and remembering; summarising; assessing credibility). Their answers were compared to those given by a group of experts, and received a metacognitive score accordingly. Higher scores in the index mean that the judgements of students and experts aligned closely - that is, they showed stronger meta-cognitive skills. On this metric, students from all education systems in Southeast Asia, except Singapore, showed weaker meta-cognitive skills than the average student across OECD countries (Figure 3.11). Students in the region appear to struggle most when asked to choose the best strategies for assessing credibility, followed by the strategies for summarising information. Just to give an example, students in the region were considerably more likely than students across OECD countries to say that "clicking on the link to fill out the form" was an appropriate strategy when receiving an email from a well-known mobile phone operator telling them that they had won a smartphone and all they needed to do was fill out an online form to receive it.

Figure 3.11. Meta-cognitive skills in reading Index units

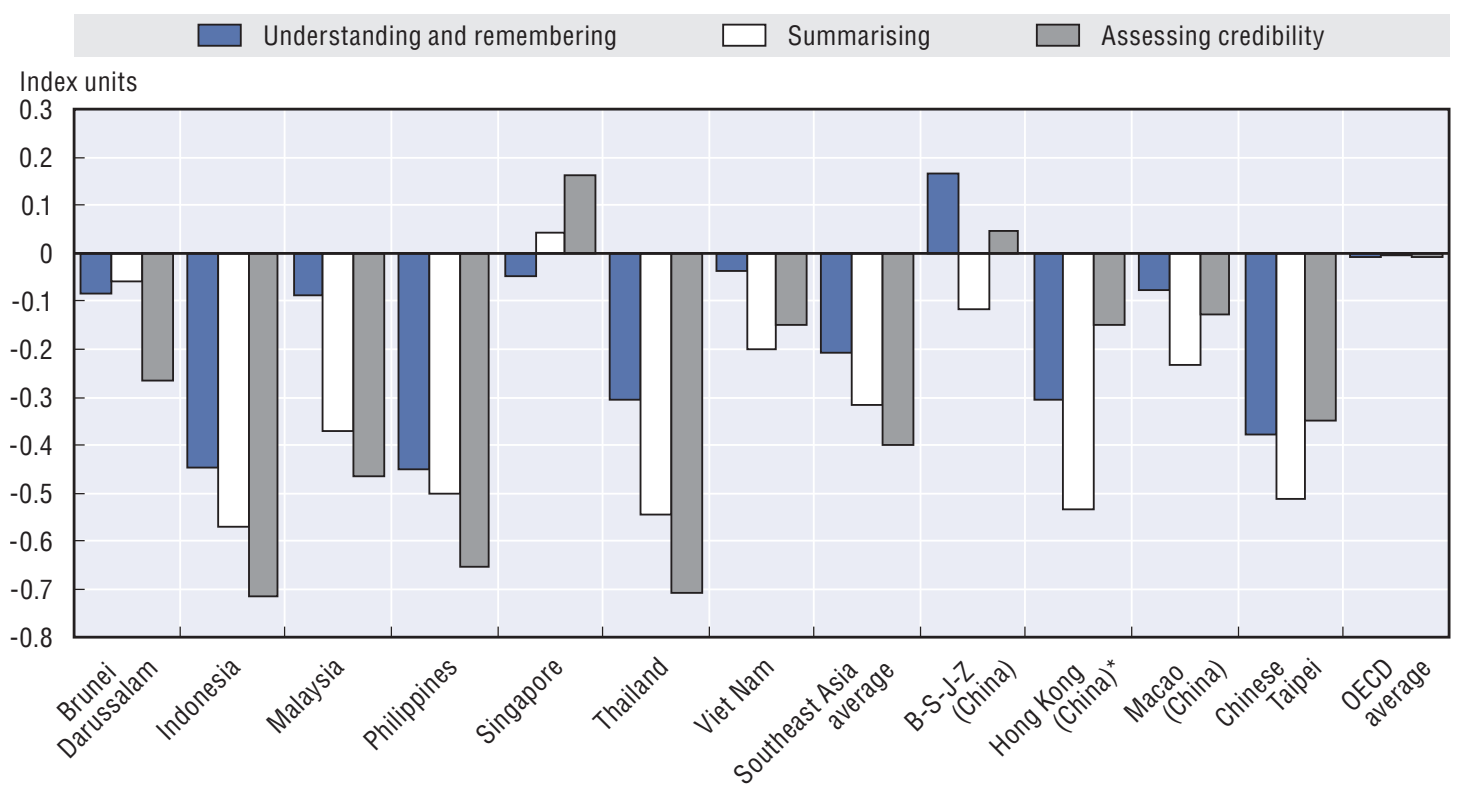

Note: * PISA 2018 data did not meet the PISA technical standards but were accepted as largely comparable. Source: OECD, PISA 2018 Database.

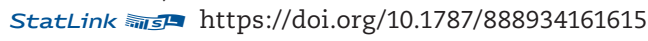




\section{Some policy recommendations for the education systems in the region}

Providing one-size-fits-all recommendations for such a diverse region as Southeast Asia can be challenging, even counterproductive. On one end, Singapore has consistently been one of the top-performing school systems in PISA since its first participation in 2009. Even if its equity outcomes in education could still be improved, the Singaporean education system has been an inspiration for other education systems worldwide. On the other end, in Cambodia, only about one in ten students achieved the minimum level of proficiency in reading, mathematics or science. Given their shared membership in the Association of Southeast Asian Nations (ASEAN), Singapore's neighbours can draw valuable lessons from its education system, which played a key role in its transition from a "Third" to a "First" World economy (Yew, 2012). This would perfectly align with the PISA spirit, which promotes sharing experiences, policies and best practices between education systems, experts and social agents.

Other than learning from neighbouring countries, some general recommendations for the school systems in Southeast Asia could include:

- Keep improving access to education without sacrificing the quality of the school system. Indonesia, for instance, clearly shows that increasing the share of 15-yearolds covered by the PISA sample does not necessarily lead to lower average performance in the PISA assessments.

- Make learning time more productive by building a skilled and dedicated teacher workforce, and encourage teachers to use multiple teaching strategies and types of assessments. In most countries in the region, and especially in Indonesia, the Philippines and Thailand, instruction relies too heavily on teacher-directed strategies. Paying more attention to teachers' digital literacy is also important to support learning, particularly to prepare students for the digital era.

- Address gender differences in students' participation in various training and studies, including those related to science and engineering, to support the efforts in promoting equal representation of men and women in different occupations.

- Create a positive learning environment, where students do not disrupt the flow of instruction and respect other students, teachers support their students and co-operate with colleagues, school principals react swiftly when behavioural and academic problems arise, and parents participate in school activities.

- Invest greater resources in the school system, especially in the countries where education expenditure is low by international standards, like in Malaysia, the Philippines, Thailand and Viet Nam.

- Allocate resources more equitably among schools, especially in Indonesia, the Philippines and Thailand, and provide additional support to disadvantaged schools. Improving access to ICT infrastructure and tools in disadvantaged schools, in particular those in rural and remote areas, is also necessary.

\section{Note}

1. Disadvantaged students are in the bottom quarter of the PISA index of economic, social and cultural status in their own country/economy, whereas high-achieving students are those who scored amongst the top $25 \%$ of students within their country or economy on the PISA test. 


\section{References}

Artelt, C., U. Schiefele and W. Schneider (2001), "Predictors of reading literacy", European Journal of Psychology of Education, Vol. 16/3, pp. 363-383, http://dx.doi.org/10.1007/BF03173188.

Baker, L. and L. Beall (2009), "Metacognitive processes and reading comprehension”, in Israel, S. and G. Duffy (eds.), Handbook of Research on Reading Comprehension, Routledge, New York, NY.

Cingano, F. (2014), "Trends in Income Inequality and its Impact on Economic Growth", OECD Social, Employment and Migration Working Papers, No. 163, OECD, Paris, http://dx.doi. org/10.1787/5jxrjncwxv6j-en.

Croft, A., T. Schmader and K. Block (2015), “An Underexamined Inequality: Cultural and Psychological Barriers to Men's Engagement With Communal Roles", Personality and Social Psychology Review, Vol. 19/4, pp. 343-370, http://dx.doi.org/10.1177/1088868314564789.

Downey, D. and D. Condron (2016), "Fifty Years since the Coleman Report", Sociology of Education, Vol. 89/3, pp. 207-220, http://dx.doi.org/10.1177/0038040716651676.

Echazarra, A. et al. (2016), "How teachers teach and students learn: Successful strategies for school", OECD Education Working Papers, No. 130, OECD Publishing, Paris, https://www.oecdilibrary.org/education/how-teachers-teach-and-students-learn_5jm29kpt0xxx-en (accessed on 27 March 2020).

Evans, M. et al. (2010), "Family scholarly culture and educational success: Books and schooling in 27 nations", Research in Social Stratification and Mobility, Vol. 28/2, pp. 171-197, http://dx.doi. org/10.1016/j.rssm.2010.01.002.

Hoge, D., E. Smit and S. Hanson (1990), "School experiences predicting changes in self-esteem of sixth- and seventh-grade students", Journal of Educational Psychology, Vol. 82/1, pp. 117-127, http://psycnet.apa.org/buy/1990-21091-001 (accessed on 4 October 2018).

Hoy, W., J. Hannum and M. Tschannen-Moran (1998), "Organizational Climate and Student Achievement: A Parsimonious and Longitudinal View", Journal of School Leadership, Vol. 8/4, pp. 336-359, http://dx.doi.org/10.1177/105268469800800401.

Kim, B., H. Park and Y. Baek (2009), "Not just fun, but serious strategies: Using meta-cognitive strategies in game-based learning", Computers and Education, Vol. 52/4, pp. 800-810, http://dx.doi. org/10.1016/j.compedu.2008.12.004.

MacNeil, A., D. Prater and S. Busch (2009), "The effects of school culture and climate on student achievement", International Journal of Leadership in Education, Vol. 12/1, pp. 73-84, http://dx.doi. org/10.1080/13603120701576241.

Martin, A. and H. Marsh (2006), "Academic resilience and its psychological and educational correlates: A construct validity approach", Psychology in the Schools, Vol. 43/3, pp. 267-281, http://dx.doi.org/10.1002/pits.20149.

MoEYS (2018), Education in Cambodia: Findings from Cambodia's Experience in PISA for Development.

Mostafa, T., A. Echazarra and H. Guillou (2018), "The science of teaching science: An exploration of science teaching practices in PISA 2015", OECD Education Working Papers, No. 188, OECD Publishing, Paris, http://dx.doi.org/10.1787/f5bd9e57-en.

OECD (2019a), Economic Outlook for Southeast Asia, China and India 2020: Rethinking Education for the Digital Era, OECD Publishing, Paris, https://doi.org/10.1787/1ba6cde0-en.

OECD (2019b), PISA 2018 Assessment and Analytical Framework, PISA, OECD Publishing, Paris, https://dx.doi.org/10.1787/b25efab8-en.

OECD (2019c), PISA 2018 Results (Volume I): What Students Know and Can Do, OECD Publishing, Paris, https://doi.org/10.1787/5f07c754-en.

OECD (2019d), PISA 2018 Results (Volume II): Where All Students Can Succeed, PISA, OECD Publishing, Paris, https://dx.doi.org/10.1787/b5fd1b8f-en.

OECD (2019e), PISA 2018 Results (Volume III): What School Life Means for Students' Lives, PISA, OECD Publishing, Paris, https://dx.doi.org/10.1787/acd78851-en.

OECD (2019f), TALIS 2018 Results (Volume I): Teachers and School Leaders as Lifelong Learners, TALIS, OECD Publishing, Paris, https://dx.doi.org/10.1787/1d0bc92a-en.

OECD (2018), A Broken Social Elevator? How to Promote Social Mobility, OECD Publishing, Paris, https://dx.doi.org/10.1787/9789264301085-en.

OECD (2015), "What do parents look for in their child's school?", in PISA in Focus, OECD Publishing, Paris, http://doi.org/10.1787/5js1qfw4n6wj-en. 
Rees, G. and G. Main (2015), Children's views on their lives and well-being in 15 countries: A report on the Children's Worlds survey, 2013-14, Children's Worlds Project, York, UK, http://www.isciweb.org. (accessed on 19 June 2019).

Sirin, S. (2005), "Socioeconomic Status and Academic Achievement: A Meta-Analytic Review of Research", Review of Educational Research, Vol. 75/3, pp. 417-453, http://dx.doi. org/10.3102/00346543075003417.

Spaull, N. and S. Taylor (2015), "Access to what? Creating a composite measure of educational quantity and educational quality for 11 African countries", Comparative Education Review, Vol. 59/1, pp. 133-165, http://dx.doi.org/10.1086/679295.

Thomson, S. (2018), "Achievement at school and socioeconomic background-an educational perspective", npj Science of Learning, Vol. 3/1, pp. 1-2, http://dx.doi.org/10.1038/s41539-018-0022-0.

UNESCO (2019), UIS Statistics (database), the United Nations Educational, Scientific and Cultural Organization, Paris, http://data.uis.unesco.org/.

Way, N., R. Reddy and J. Rhodes (2007), "Students' Perceptions of School Climate During the Middle School Years: Associations with Trajectories of Psychological and Behavioral Adjustment", American Journal of Community Psychology, Vol. 40/3-4, pp. 194-213, http://dx.doi.org/10.1007/ s10464-007-9143-y.

Yew, L. K. (2012), “From third world to first: The Singapore story, 1965-2000", Marshall Cavendish International Asia Pte Ltd. 


\section{Annex A. Statistical annex}

Table A.1. Real GDP growth in ASEAN, China and India, 2018-21

Percentage

\begin{tabular}{|c|c|c|c|c|c|}
\hline & 2018 & 2019 & 2020 & $\begin{array}{l}\text { Changes from the previous } \\
\text { forecast (Nov. 2019) }\end{array}$ & 2021 \\
\hline \multicolumn{6}{|l|}{ ASEAN- 5 countries } \\
\hline Indonesia & 5.2 & 5.0 & -2.8 & $\downarrow$ & 5.2 \\
\hline Malaysia & 4.8 & 4.3 & -3.9 & $\downarrow$ & 5.9 \\
\hline Philippines & 6.3 & 6.0 & -3.2 & $\downarrow$ & 7.0 \\
\hline Thailand & 4.2 & 2.4 & -6.7 & $\downarrow$ & 4.9 \\
\hline Viet Nam & 7.1 & 7.0 & 2.5 & $\downarrow$ & 7.2 \\
\hline \multicolumn{6}{|c|}{ Brunei Darussalam and Singapore } \\
\hline Brunei Darussalam & 0.1 & 3.9 & 1.4 & $\downarrow$ & 3.3 \\
\hline Singapore & 3.4 & 0.7 & -4.4 & $\downarrow$ & 3.5 \\
\hline \multicolumn{6}{|l|}{ CLM countries } \\
\hline Cambodia & 7.5 & 7.1 & -1.0 & $\downarrow$ & 5.8 \\
\hline Lao PDR & 6.2 & 6.1 & 1.0 & $\downarrow$ & 5.0 \\
\hline Myanmar & 6.4 & 6.8 & 2.0 & $\downarrow$ & 7.3 \\
\hline \multicolumn{6}{|l|}{ China and India } \\
\hline $\begin{array}{l}\text { China } \\
\end{array}$ & 6.7 & 6.1 & -2.6 & $\downarrow$ & 6.8 \\
\hline India & 6.1 & 4.2 & -3.7 & $\downarrow$ & 7.9 \\
\hline Average of ASEAN-10 & 5.3 & 4.7 & -2.8 & $\downarrow$ & 5.6 \\
\hline Average of Emerging Asia & 6.3 & 5.4 & -2.9 & $\downarrow$ & 6.8 \\
\hline
\end{tabular}

Note: Data are as of 26 June 2020. Data for India and Myanmar relate to fiscal years. For Lao PDR, 2019 GDP growth data are estimates. The projections for China, India and Indonesia for 2020 and 2021 are based on the OECD Economic Outlook 107 (database). The projections assume "single hit" scenarios, in which a second big outbreak is avoided. They also assume that world GDP is declining in 2020 but will almost regain pre-crisis level (2016 level) in 2021. Source: OECD Development Centre.

Table A.2. Current account balance of ASEAN, China and India, 2019-21 Percentage of GDP

\begin{tabular}{|c|c|c|c|}
\hline & 2019 & 2020 & 2021 \\
\hline \multicolumn{4}{|l|}{ ASEAN-5 } \\
\hline Indonesia & -2.7 & -2.8 & -2.8 \\
\hline Malaysia & 3.4 & -0.1 & -2.0 \\
\hline Philippines & -0.1 & -2.4 & -2.1 \\
\hline Thailand & 7.0 & 4.9 & 5.2 \\
\hline Viet Nam & 5.0 & 0.2 & 1.0 \\
\hline \multicolumn{4}{|l|}{ Brunei Darussalam and Singapore } \\
\hline Brunei Darussalam & 6.6 & 4.9 & 8.0 \\
\hline Singapore & 17.0 & 15.0 & 15.2 \\
\hline \multicolumn{4}{|l|}{ CLM countries } \\
\hline Cambodia & -15.5 & -19.6 & -17.0 \\
\hline Lao PDR & -4.5 & -9.7 & -8.0 \\
\hline Myanmar & 0.4 & -4.8 & -4.0 \\
\hline \multicolumn{4}{|l|}{ China and India } \\
\hline China & 1.0 & 0.6 & 0.9 \\
\hline India & -1.0 & -0.3 & -0.6 \\
\hline Average of ASEAN 10 countries & 1.8 & -0.2 & -0.2 \\
\hline Average of Emerging Asia & 0.7 & 0.2 & 0.3 \\
\hline
\end{tabular}

Note: Data are as of 26 June 2020. Data for India and Myanmar relate to fiscal years. For Lao PDR, 2019 GDP growth data are estimates. The projections for China, India and Indonesia for 2020 and 2021 are based on the OECD Economic Outlook 107 (database). The projections assume "single hit" scenarios, in which a second big outbreak is avoided. They also assume that world GDP is declining in 2020 but will almost regain pre-crisis level (2016 level) in 2021. Source: OECD Development Centre. 


\section{Economic Outlook for Southeast Asia, China and India 2020 - UPDATE}

\section{MEETING THE CHALLENGES OF COVID-19}

The Economic Outlook for Southeast Asia, China and India is a bi-annual publication on regional economic growth, development and regional integration in Emerging Asia. It focuses on the economic conditions of the Association of Southeast Asian Nations (ASEAN) member countries: Brunei Darussalam, Cambodia, Indonesia, Lao PDR, Malaysia, Myanmar, the Philippines, Singapore, Thailand and Viet Nam. It also addresses relevant economic issues in China and India to fully reflect economic developments in the region. The update of the Outlook comprises three main parts, each highlighting a particular dimension of recent economic developments in the region. The first part presents the regional economic monitor, depicting the economic outlook and macroeconomic challenges in the region. The second and third parts consist of special thematic chapters addressing major issues facing the region. The second chapter of this update focuses on the COVID-19 outbreak, discussing in particular the socio-economic impacts of the pandemic. An analysis of the quality of education in the region is discussed in the third chapter.

Consult this publication on line at $h t t p s: / / d o i . o r g / 10.1787 / e 8 c 90 b 68-e n$

This work is published on the OECD iLibrary, which gathers all OECD books, periodicals and statistical databases. Visit www.oecd-ilibrary.org for more information.
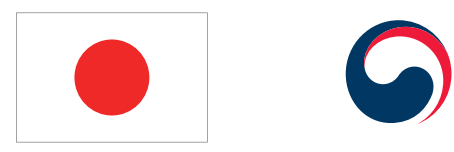

The Government of the Republic of Korea

JAPANGOV THE GOVERNMENT OF JAPAN
Schweizerische Eidgenossenschaft

Confédération suisse

Confederazione Svizzera

Confederaziun svizra

Swiss Confederation

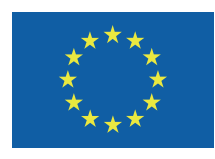

Co-funded by the European Union 